VARIASI SPASIAL DAN TEMPORAL SIFAT ALIRAN, PERILAKU

BANJIR, DAN RESPONS DEBIT TERHADAP HUJAN

DI SISTEM DRAINASE KARST PINDUL,

KABUPATEN GUNUNGKIDUL

\title{
SKRIPSI
}

Diajukan untuk memenuhi syarat

memperoleh gelar kesarjanaan S1 pada

Fakultas Geografi UGM

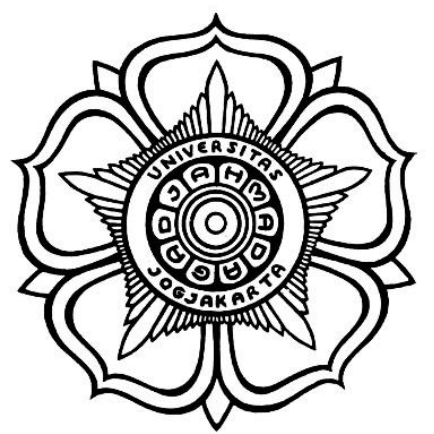

Oleh:

Afid Nurkholis

NIM. 13/348596/GE/07606

KEMENTERIAN RISET, TEKNOLOGI, DAN PENDIDIKAN TINGGI

UNIVERSITAS GADJAH MADA

FAKULTAS GEOGRAFI

DEPARTEMEN GEOGRAFI LINGKINGAN

YOGYAKARTA 


\title{
LEMBAR PENGESAHAN
}

Skripsi dengan judul

\section{VARIASI SPASIAL DAN TEMPORAL SIFAT ALIRAN, PERILAKU BANJIR, DAN RESPONS DEBIT TERHADAP HUJAN DI SISTEM DRAINASE KARST PINDUL, KABUPATEN GUNUNGKIDUL}

\author{
Disusun oleh: \\ Afid Nurkholis \\ 13/348596/GE/07606
}

diuji pada hari dan tanggal,

Selasa, 17 Oktober 2017
dinyatakan lulus pada hari dan tanggal,
Selasa, 17 Oktober 2017

Oleh tim penguji skripsi,

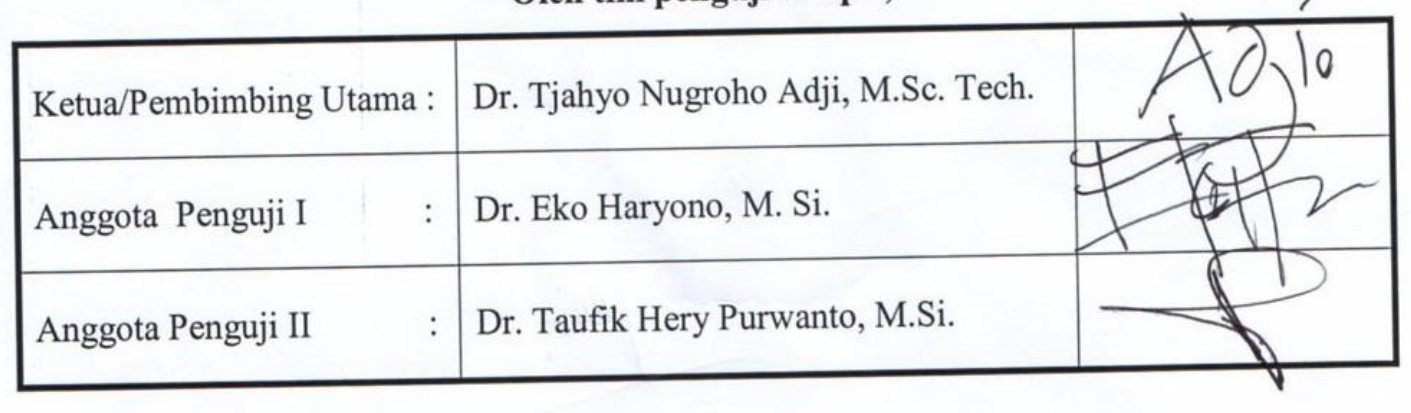

Yogyakarta, Oktober 2017

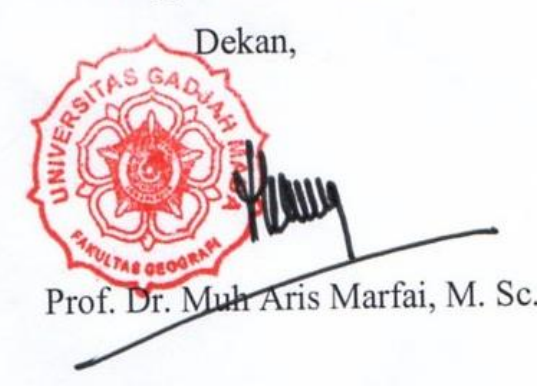




\section{SURAT PERNYATAAN ORISINALITAS PENELITIAN}

Saya yang bertanda tangan di bawah ini:

Nama mahasiswa $\quad$ : Afid Nurkholis

No. mahasiswa $\quad: 13 / 348596 / \mathrm{GE} / 07606$

Program studi : : Geografi Lingkungan

Tempat, tanggal lahir $\quad$ : Bantul, 29 Mei 1993

Alamat rumah : : Nyutran MG II 1509 Yogyakarta

Telepon :082136271248

Dengan ini, saya menyatakan bahwa skripsi yang berjudul Variasi Spasial dan Temporal Sifat Aliran, Perilaku Banjir, dan Respons Debit Terhadap Hujan di Sistem Drainase Karst Pindul, Kabupaten Gunungkidul adalah benar-benar karya asli (orisinil) yang dibuat oleh saya sendiri dan belum pernah dipublikasikan di media apapun.

Demikian surat pernyataan ini dibuat, agar dapat dipergunakan sebagaimana mestinya.

Yogyakarta, 24 Oktober 2017

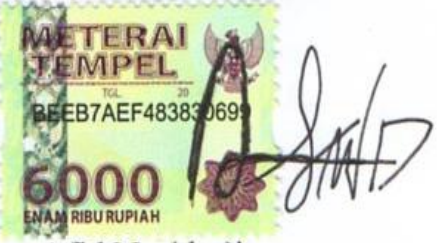

Afid Nurkholis 


\title{
VARIASI SPASIAL DAN TEMPORAL SIFAT ALIRAN, PERILAKU BANJIR, DAN RESPONS DEBIT TERHADAP HUJAN DI SISTEM DRAINASE KARST PINDUL, KABUPATEN GUNUNGKIDUL
}

\begin{abstract}
Intisari
Sebagai bentanglahan karst, Sistem Pindul memiliki keunikan berupa adanya zona dengan dominasi sungai bawah tanah dan sungai permukaan. Aktivitas manusia berupa wisata gua, pemukiman, dan pertanian juga telah intens if memanfaatkan sumberdaya air di wilayah ini. Berdasarkan hal tersebut, penelitian ini akan melakukan karakterisasi Sistem Drainase Karst Pindul. Tujuan dari penelitian ini adalah: (1) menemukenali variasi spasial dan temporal dari pelepasan komponen aliran dan prosentase aliran dasar (PAD); (2) menemukenali perilaku banjir; (3) menemukenali perilaku Sistem Drainase Karst Pindul dalam merespons hujan.

Data yang digunakan adalah debit aliran dan hujan yang diukur pada interval 15 menit di Gua Pindul (outlet sistem karst) dan Sinking Stream Kedungbuntung. Kedua data diukur selama 6 bulan (Januari-Juni). Data hujan dicatat menggunakan alat logger hujan yang dipasang pada tengah sistem karst. Data tinggi muka air (TMA) dicatat menggunakan tiga alat logger muka air yang dipasang di kedua lokasi (masing-masing satu buah) dan sebagai logger kalibrasi (satu buah). Perhitungan konstanta resesi dilakukan untuk menganalisis pelepasan komponen aliran. Pemisahan aliran dasar dilakukan untuk menghitung PAD. Kedua analisis mencerminkan sifat aliran Sistem Drainase Karst Pindul. Perilaku banjir dianalisis menggunakan perhitungan hujan efektif dan analisis komponen hidrogaf banjir. Time series analysis digunakan untuk menemukenali respons sistem karst terhadap hujan.

Hasil penelitian menunjukkan Sistem Drainase Karst Pindul memiliki sifat aliran yang bersifat campuran (mixed). Sistem karst memiliki pelepasan aliran conduit dan perilaku banjir yang cepat cepat $\left(\mathrm{K}_{\mathrm{c}}<0,5\right.$ dan $\mathrm{T}_{\mathrm{p}}=2,7$ jam), namun masih mampu menyimpan airtanah dengan baik $\left(\mathrm{K}_{\mathrm{b}}>0,98\right.$ dan $\mathrm{T}_{\mathrm{b}}=14$ jam). Secara spasial, Gua Pindul memiliki pelepasan komponen aliran conduit dan fissure yang identik dengan Kedungbuntung karena Gua Pindul merupakan outlet dari sungai bawah tanah dan Kedungbuntung adalah sungai permukaan. Sementara itu, Gua Pindul melepaskan komponen aliran diffuse yang lebih cepat dibandingkan Kedungbuntung. Hal ini disebabkan karena Gua Pindul diimbuh oleh sistem sungai bawah tanah sedangkan Kedungbuntung diimbuh oleh akuifer dengan dominasi diffuse. Secara temporal, Sistem Drainase Karst Pindul memiliki perilaku banjir yang lebih besar pada akhir musim penghujan. Hal ini disebabkan karena sistem karst telah jenuh.
\end{abstract}

Kata Kunci: perilaku banjir, respons sistem karst, sifat aliran, Sistem Karst Pindul 


\title{
SPATIAL AND TEMPORAL VARIATION OF FLOW PROPERTIES, FLOOD CHARACTERISTICS, AND RAINFALL-RUNOFF RELATIONSHIP IN PINDUL KARTS DRAINAGE SYSTEM, GUNUNGKIDUL REGENCY
}

\begin{abstract}
As a karst landscape, Pindul System has unique characteristics. There are zones with dominating surface rivers and with dominance of underground rivers. Human activities in the form of cave tourism, settlements, and agriculture have been intensively using this water resources. Hence, this research will characterize Pindul Karst Drainage System. The objectives of this research are: (1) Identify the karst flow properties; (2) Identify flood characteristics of the karst system; (3) Identify the transformations of the input signal (rainfall) and output signal (discharge);

Water level logger is installed in Pindul Cave and Kedungbuntung Sinking Stream to get the discharge data every 15 minutes. Rainfall data obtained by installing rain gauge on the middle of karst drainage system. Both data were collected for six months (January-June 2017). Calculations of recession constant and baseflow separation are undertaken for define flow properties. Flood characteristics are obtained by flood hydrograph analysis and effective rainfall calculations. Time series analysis was applied in order to identify rainfall-runoff relationships.

The results showed that Pindul Karst Drainage System has mixed karst flow components. The karst system has shortest time of conduit flow and time to peak ( $\mathrm{K}_{\mathrm{c}}<0.5$; duration of conduit $<30$ minutes; $\mathrm{T}_{\mathrm{p}}=2.7$ hours), but still good capability to store groundwater $\left(\mathrm{K}_{\mathrm{b}}>0.98\right.$ and $\mathrm{T}_{\mathrm{b}}=14$ hours). Spatially, Pindul Cave and Kedungbuntung have identical release of conduit and fissure flow. Pindul Cave is an outlet of underground river while Kedungbuntung is a surface river. Meanwhile, Pindul Cave releases diffuse flow components faster than Kedungbuntung. That is because the Pindul Cave is revharged by underground river system while Kedungbuntung is recharged by aquifer with diffuse dominance cracks. Temporally, Pindul Karst Drainage System has greater flooding characteristics at the end of rainy season. That is because the karst system has been saturated.
\end{abstract}

Keywords: flood characteristics, flow properties, Pindul Karst System, rainfallrunoff relationship 


\section{KATA PENGANTAR}

Penelitian ini merupakan salah satu syarat untuk memperoleh gelar kesarjanaan di Departemen Geografi Lingkungan, Fakultas Geografi, Universitas Gadjah Mada. Selain itu, penelitian ini juga merupakan bagian dari Hibah Penelitian Unggul Perguruan Tinggi (PUPT) Dikti tahun 2016 yang berjudul "Karakterisasi Hidrologi dan Banjir di Sungai Bawah Tanah Gua Pindul untuk Mendukung Pengelolaan Pariwisata Berkelanjutan Berbasis Manajemen Kebencanaan". Sistem Drainse Karst Gua Pindul merupakan obyek utama dalam penelitian ini. Lokasi tersebut pada saat ini terkenal dengan wisata alam yang berupa susur gua. Selain dimanfaatkan untuk kegiatan pariwisata, sumberdaya air pada sistem karst ini banyak digunakan untuk kepentingan pertanian dan rumah tangga. Oleh karena itu, penelitian ini berusaha untuk mengungkap perilaku/karakteristik dari sistem drainase karst dalam kaitannya dengan sumber daya air.

Penulis memohon kritik dan saran apabila dalam penelitian ini terdapat hal-hal yang perlu diperbaiki. Penelitian ini dapat diselesaikan dengan bantuan berbagai pihak. Oleh karena itu, penulis ingin menyampaikan ucapan terimakasih kepada:

1. Ibu Safrotun, Bpk. Dwi Riyanto, adik saya Ela Bahar, dan simbah Waljiyah yang selalu memberi suasanya nyaman di rumah dan memberikan banyak doa dan bantuan.

2. Dr. Tjahyo Nugroho Adji, M.Sc.Tech. selaku dosen pembimbing skripsi yang selalu memberikan dukungan dan bimbingan selama penelitian ini.

3. Dr. Eko Haryono, M.Si. selaku dosen penguji skripsi dan pembina Karst Research Group FGE UGM yang banyak memberikan pengetahuan dalam diskusi dan kegiatan lapangan.

4. Dr. rer. nat. Muhammad Anggri Setiawan, M.Si. dan Nugroho Christanto, M.Si. yang telah memberi pengetahuan baru mengenai hidrologi dan geomorfologi. 
5. Ahmad Cahyadi, M.Sc. yang telah mengizinkan penulis untuk bergabung dalam penelitian hibah PUPT tahun 2016 dan memberikan banyak saran dan bantuan dalam penelitian ini.

6. Prof. Dr. rer. nat. Muh. Aris Marfai, M.Sc. selaku dosen pembimbing akademik dan Dr. Emilya Nurjani, M.Si. selaku sekretaris departemen yang banyak memberikan motivasi selama kuliah.

7. Dr. Slamet Suprayogi, M.S. selaku ketua tim hibah PUPT tahun 2016 yang telah mengizinkan penulis untuk terlibat dalam hibah tersebut.

8. Para senior di Karst Research Group FGE UGM (Romza Fauzan Agniy, S.Si., Hendy Fatchurohman, S.Si., Igor Bahtiar, S.Si., Eko Bayu Dharma Putra, S.Si., dan yang lainnya) yang telah banyak membantu dalam diskusi kelas dan kegiatan lapangan.

9. Tim Peneliti Sistem Karst Pindul (Galih Dwi Jayanto, N Yogi Jurnawan, Fuad Dwi R, Agung Hidayat, Tri Mulia Anisa, Hanindha Pradipa, Mutiara Ayu, Egha Friyansai, Erna Puji Lestari) yang telah berjuang bersama melakukan penelitian.

10. Bpk. Suratmin dan keluarga, Bpk Subagyo selaku pimpinan operator wisata Dewa Bedjo, serta warga sekitar Gua Pindul yang telah memberikan tumpangan menginap dan bantuan lain selama penelitian.

11. Keluarga Himpunan Mahasiswa Geografi Lingkungan (EGSA UGM) yang memberikan pengalaman berorganisasi dan berbagai kenangan selama perkuliahan. Terimakasih kepada Muhammad Naufal, M Jundi Bariq, Najib, dan Aji Dwi P yang telah membantu pengukuran lapangan.

12. Sahabat perjuangan Geografi Lingkungan 2013 yang selalu menemani hari-hari selama empat tahun terakhir. Terimakasih kepada Surya Subda N, Ghina Nur F, Novian Khoirul A, Briantama Asmara, Zahra Octavia, Vischa Findanissa, Maulana Yudinugroho yang telah membantu pengambilan data lapangan. 


\section{DAFTAR ISI}

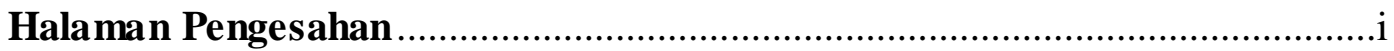

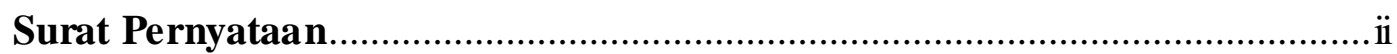

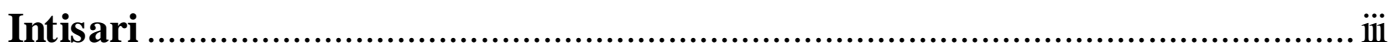

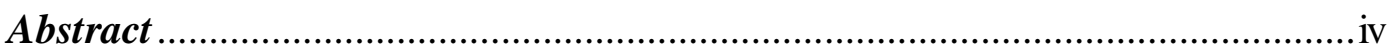

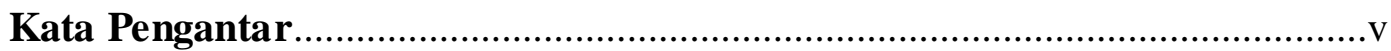

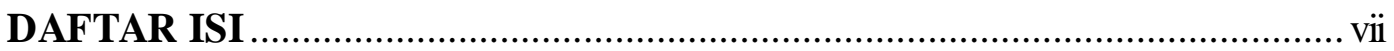

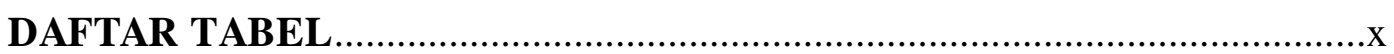

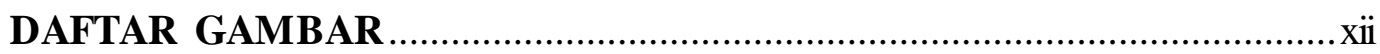

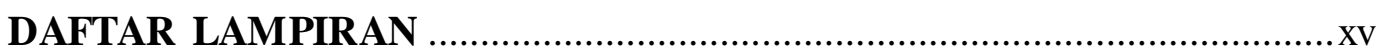

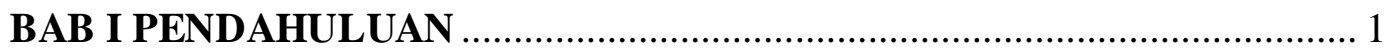

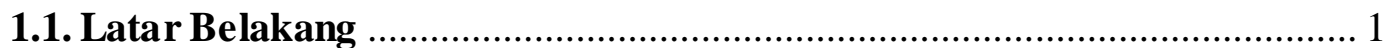

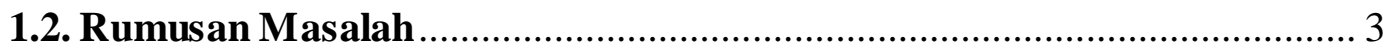

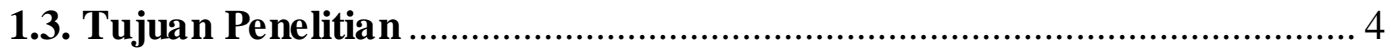

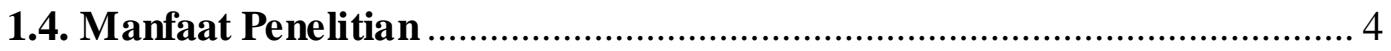

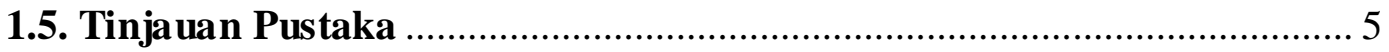

1.5.1. Konsep Karst dan Karstifikasi................................................................. 5

1.5.2. Konsep Sistem Drainase Karst ................................................................ 7

1.5.3. Klasifikasi Sistem Drainase Karst............................................................. 9

a. Konseptual Model Imbuhan Sistem Drainase Karst .................................... 9

b. Tipe Aliran Diffuse, Fissure, dan Conduit .............................................. 100

c. Konsep Skema 3-Dimensi Sistem Drainase Karst..................................... 111

1.5.4. Karakterisasi Sistem Drainase Karst ................................................... 122

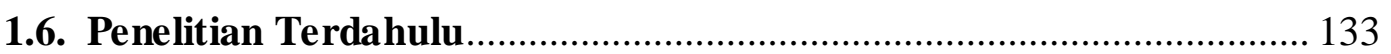

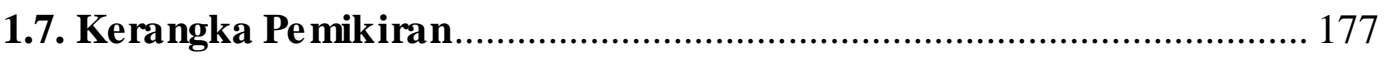

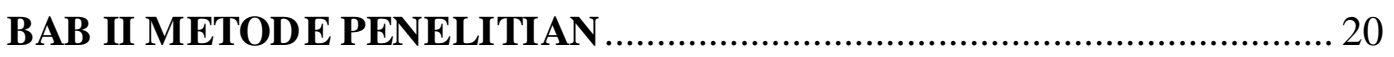

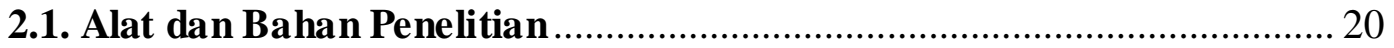

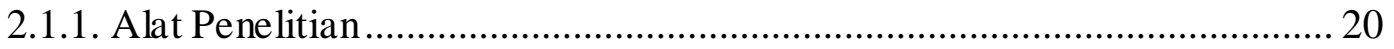

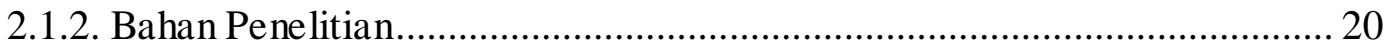

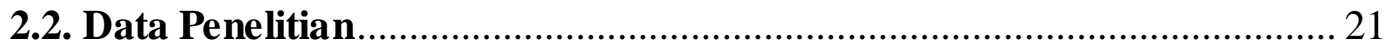

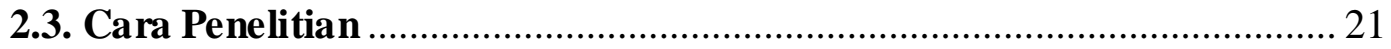

2.3.1. Teknik Pengumpulan Data ...................................................................... 21

a. Pencatatan Data Tinggi Muka Air (TMA) ................................................. 21 
b. Pencatatan Data Tebal Hujan ................................................................... 22

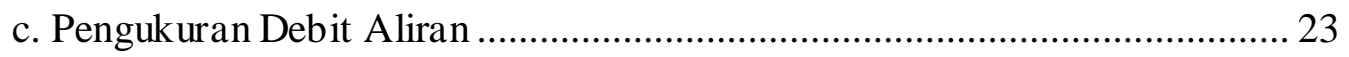

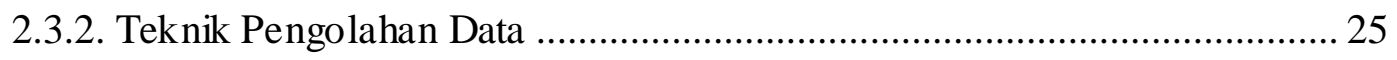

a. Pengolahan Data untuk Karakterisasi Pelepasan Komponen Aliran dan Prosentase Aliran Dasar ....................................................................... 25

b. Pengolahan Data untuk Karakterisasi Banjir............................................. 28

c. Pengolahan Data untuk Karakterisasi Respons Debit Terhadap Hujan........ 30

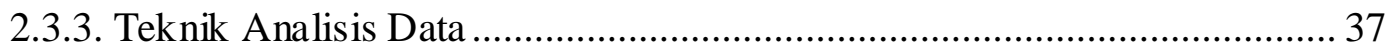

a. Analisis Data untuk Karakterisasi Pelepasan Komponen Aliran dan Prosentase Aliran Dasar .......................................................................... 37

b. Analisis Data untuk Karakterisasi Banjir .................................................. 38

c. Analisis Data untuk Karakterisasi Respons Debit Terhadap Hujan ............. 39

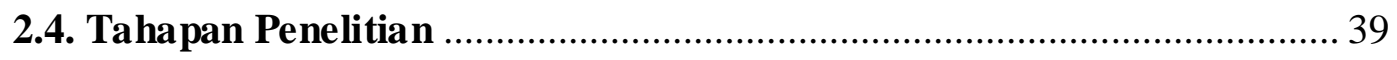

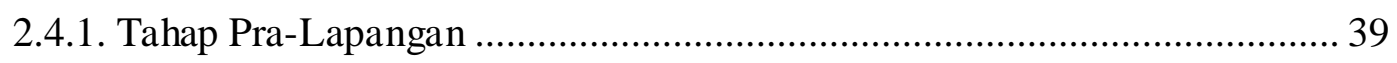

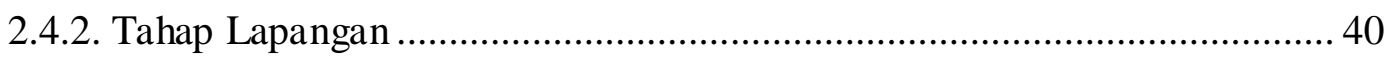

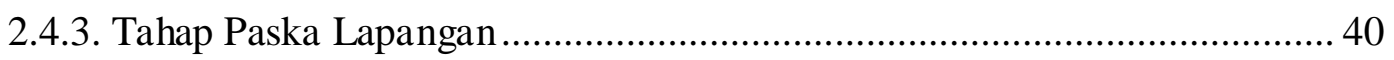

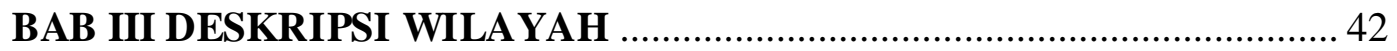

3.1. Letak, Batas, dan Luas Daerah Penelitian........................................... 42

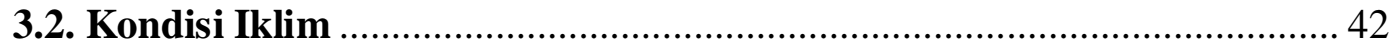

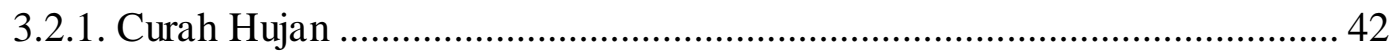

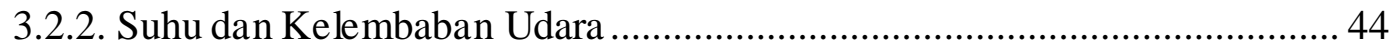

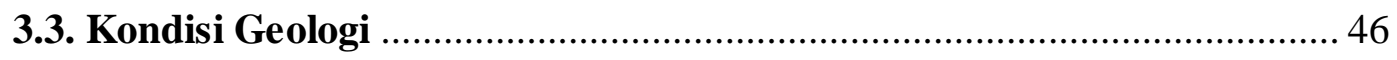

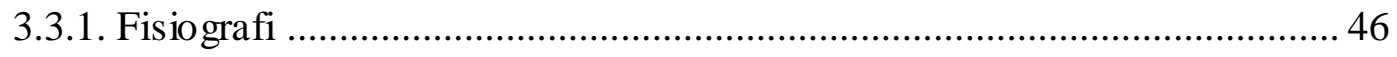

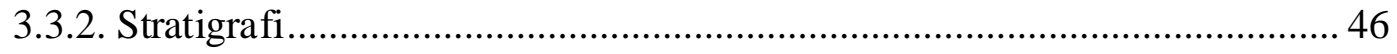

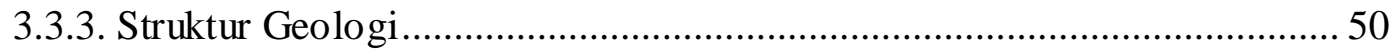

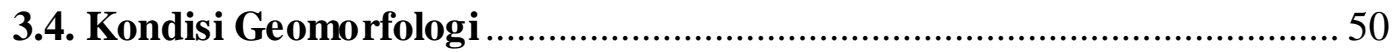

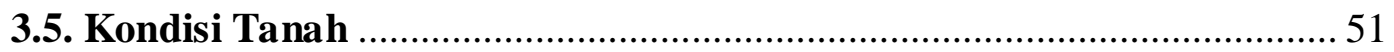

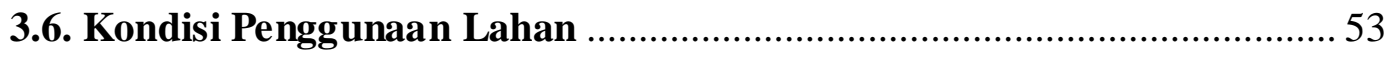

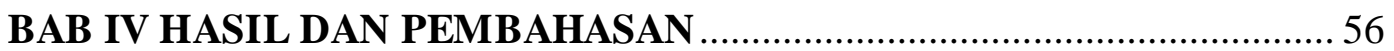

4.1. Karakteristik Pelepasan Komponen Aliran dan Prosentase Aliran Dasar .56

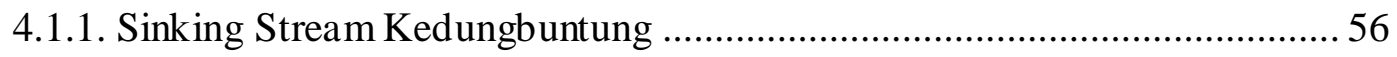

a. Rating Curve Sinking Stream Kedungbuntung ....................................... 56 
b. Konstanta Resesi Sinking Stream Kedungbuntung ................................... 57

c. Prosentase Aliran Dasar Sinking Stream Kedungbuntung .......................... 59

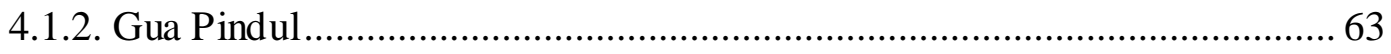

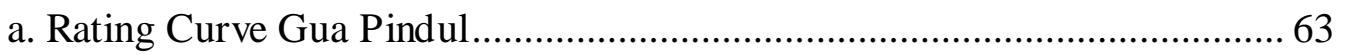

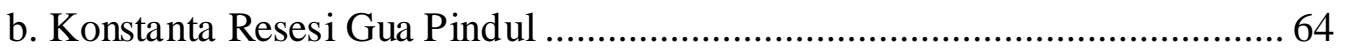

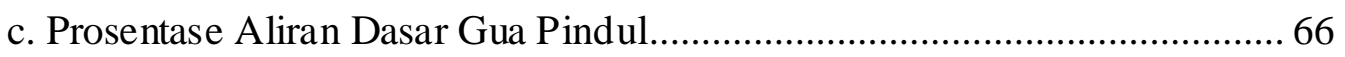

4.1.3. Variasi Spasial dan Temporal Karakteristik Aliran Sistem Drainase Karst

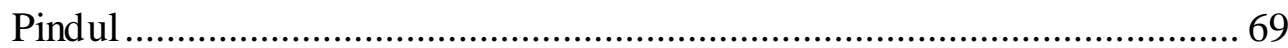

a. Variasi Spasial Pelepasan Komponen Aliran ............................................. 70

b. Variasi Spasial dan Temporal Prosentase Aliran Dasar ............................... 71

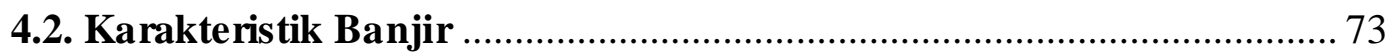

4.2.1. Sinking Stream Kedungbuntung................................................................ 73

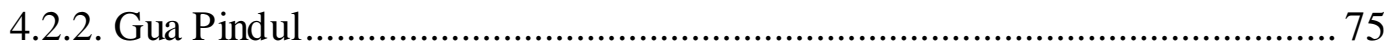

4.2.3. Variasi Spasial dan Temporal Karakteristik Banjir Sistem Drainase Karst Pindul.

4.3. Karakteristik Respons Sistem Drainase Karst Terhadap Curah Hujan 84

4.3.1. Respons Aliran Conduit .......................................................................... 84

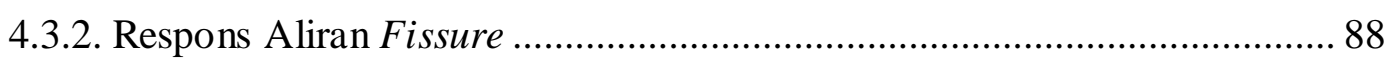

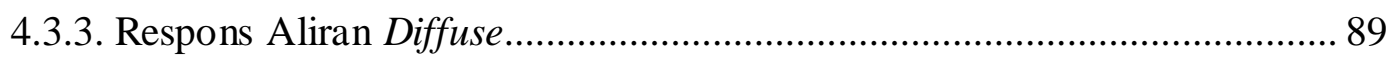

4.3.3. Variasi Spasial Respons Sis tem Drainase Karst Terhadap Curah Hujan.... 91

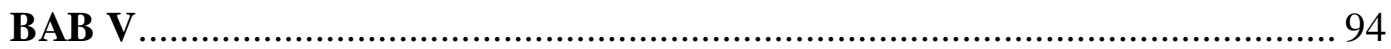

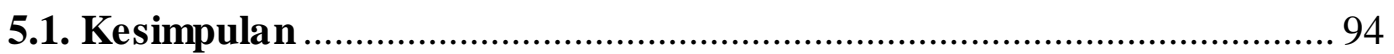

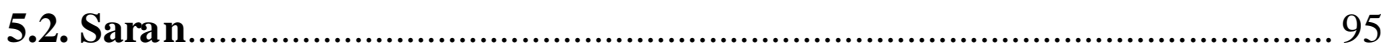

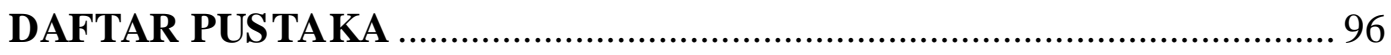

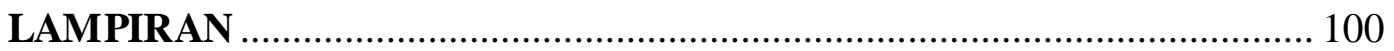




\section{DAFTAR TABEL}

Tabel 1.1 Faktor pengontrol dan pendorong proses karstifikasi ........................... 6

Tabel 1.2. Zonasi sistem drainase karst......................................................... 7

Tabel 1.3. Model karakterisasi akuifer karst pada setiap kondisi yang berbeda ...13

Tabel 1.4. Perbandingan penelitian terdahulu dengan penelitian ini .....................14

Tabel 2.1. Penilaian koefisien manning …............................................................24

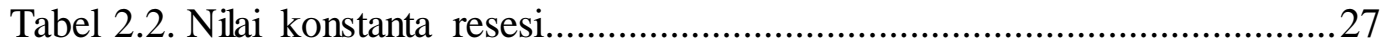

Tabel 2.3. Klasifikasi time series analysis untuk karakterisasi sistem drainase

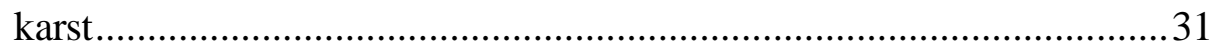

Tabel 3.1. Luas desa di Kecamatan Karangmojo ...................................................44

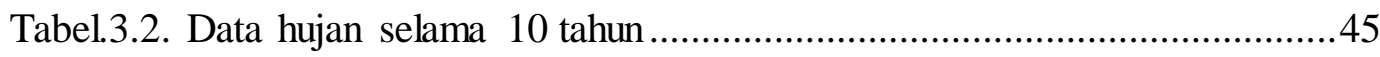

Tabel 3.3. Suhu dan kelembaban udara............................................................46

Tabel 3.4. Karakteristik jenis tanah di Sistem Karst Pindul.................................53

Tabel 3.5. Luas penggunaan lahan di Sistem Karst Pindul...................................53

Tabel 4.1. Hasil pengukuran debit aliran Sinking Stream Kedungbuntung ...........57

Tabel 4.2. Konstanta resesi, $\mathrm{T}_{\mathrm{p}}, \mathrm{T}_{\mathrm{b}}$, dan $\mathrm{Q}_{\mathrm{p}}$ dari hidrograf banjir terpilih Sinking

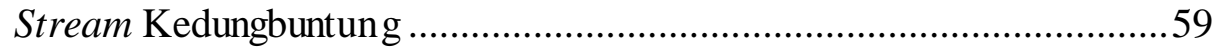

Tabel 4.3. Fluktasi PAD bulanan Sinking Stream Kedungbuntung .......................62

Tabel 4.4. PAD setiap kejadian banjir di Sinking Stream Kedungbuntung.............62

Tabel 4.5. Hasil pengukuran debit aliran Gua Pindul ...........................................64

Tabel 4.6. Konstanta Resesi, $\mathrm{T}_{\mathrm{p}}, \mathrm{T}_{\mathrm{b}}$, dan $\mathrm{Q}_{\mathrm{p}}$ hidrograf banjir terpilih di

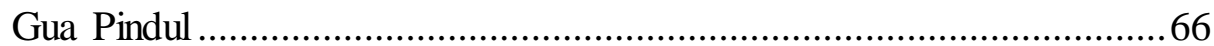

Tabel 4.7. Fluktuasi PAD bulanan Gua Pindul .....................................................69

Tabel 4.8. PAD setiap kejadian banjir Gua Pindul..............................................69

Tabel 4.9. Ringkasan nilai konstanta resesi dan parameter banjir di Gua Pindul

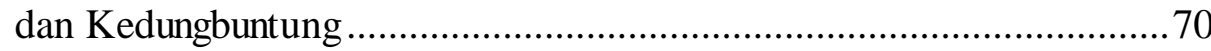

Tabel 4.10. Uji independent samples $t$-test konstanta resesi ..............................71

Tabel 4.11. PAD kejadian banjir di Gua Pindul dan Kedungbuntung ...................72 
Tabel 4.12. Komponen hidrograf banjir dan karakteristik hujan di Sinking Stream

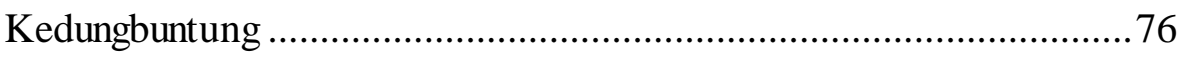

Tabel 4.13. Korelasi dan regresi simultan karakteristik hujan - debit puncak di Sinking Stream Kedungbuntung. .78

Tabel 4.14. Komponen hidrograf banjir dan karakteristk hujan di Gua Pindul.....81

Tabel 4.15. Korelasi dan regresi simultan karkteristik hujan dengan debit puncak

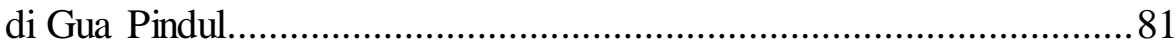

Tabel 4.16. Nilai $\mathrm{Q}_{\mathrm{p}}, \mathrm{T}_{\mathrm{p}}, \mathrm{T}_{\mathrm{lag}}$, dan $\mathrm{P}_{\mathrm{e}}$ di Gua Pindul dan Kedungbuntung .............83

Tabel 4.17. Nilai $P_{e}$ di Gua Pindul dan Kedungbuntun........................................83

Tabel 4.18. Nilai $\mathrm{R}^{2}$ uji korelasi parsial antara debit puncak dengan karakteristik hujan di Gua Pindul dan Kedungbuntung .......................................8 84

Tabel 4.19. Uji korelasi simultan dan regresi linier antara debit puncak dengan tebal, puncak, dan durasi hujan di Gua Pindul dan Kedungbuntung...84

Tabel 4.20. Hasil perhitungan time series analysis, $\mathrm{T}_{\mathrm{ag}}, \mathrm{T}_{\mathrm{b}}$, dan konstanta resesi di Gua Pindul dan Kedungbuntung .93 


\section{DAFTAR GAMBAR}

Gambar 1.1. Sistem Drainase Karst Pindul.........................................................2

Gambar 1.2. Obyek wisata di Sistem Pindul....................................................... 3

Gambar 1.3. Klasifikasi Karst Gunungsewu...................................................... 7

Gambar 1.4. Lapisan subcutaneous dan perkembangannya................................. 8

Gambar 1.5. Konseptual model aliran air pada sistem drainase karst..................9

Gambar 1.6. Klasifikasi sistem drainase karst....................................................11

Gambar 1.7. Skema tiga sifat aliran pada suatu sistem drainase karst .................12

Gambar 1.8. Hubungan imbuhan, simpanan, dan sifat aliran .............................. 12

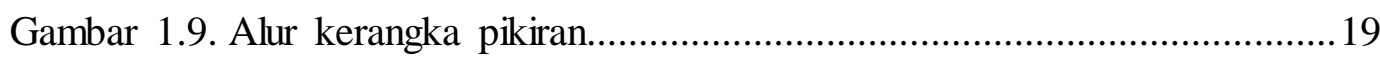

Gambar 2.1. Logger muka air Hobo U-20-01.................................................22

Gambar 2.2. Logger hujan Hobo RG-03 ........................................................22

Gambar 2.3. Pengukuan luas penampang sungai..............................................24

Gambar 2.4. Ilustrasi perhitungan kemiringan sungai dan pemasangan piskal.....25

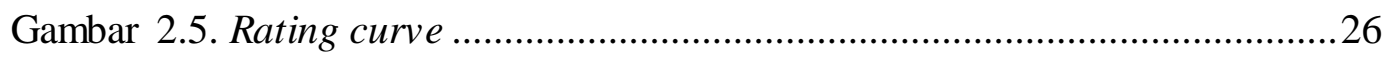

Gambar 2.6. Contoh resesi hidrograf banjir terpilih..........................................2

Gambar 2.7. Grafik hasil perhitungan hujan efektif...........................................28

Gambar 2.8. Ilustrasi parameter hidrograf banjir............................................... 30

Gambar 2.9. Ilustrasi time series analysis sebagai model black box ....................30

Gambar 2.10. Contoh grafik auto-correlation ...................................................32

Gambar 2.11. Contoh grafik spectral density ...................................................33

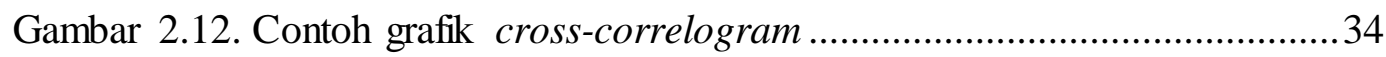

Gambar 2.13. Contoh grafik cross-amplitude .................................................... 35

Gambar 2.14. Contoh grafik phase functions..................................................... 36

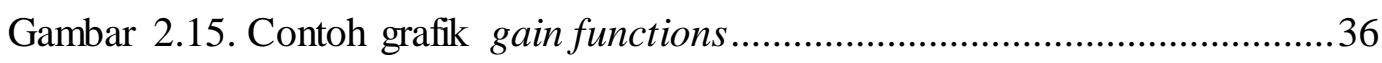

Gambar 2.16. Diagram alir penelitian.............................................................4 41

Gambar 3.1. Peta administrasi wilayah kajian.................................................43

Gambar 3.2. Rerata hujan bulanan Stasiun Karangmojo ......................................44

Gambar 3.3. Suhu dan kelembaban udara wilayah kajian ..................................45

Gambar 3.4. Fisiografi Zona Pegunungan Selatan Jawa Timur Bagian Barat......47 
Gambar 3.5. Peta Geologi wilayah Gua Pindul dan sekitarnya ............................48

Gambar 3.6. Kolom stratigrafi wilayah Gua Pindul dan sekitarnya .....................49

Gambar 3.7. Peta Bentuklahan wilayah Gua Pindul dan sekitarnya ......................52

Gambar 3.8. Peta Tanah wilayah Pindul dan sekitarnya........................................54

Gambar 3.9. Peta Penggunaan Lahan Sistem Drainase Karst Pindul ....................55

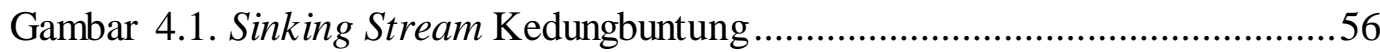

Gambar 4.2. Rating Curve Sinking Stream Kedungbuntung................................58

Gambar 4.3. Hidrograf aliran Sinking Stream Kedungbuntung .............................58

Gambar 4.4.a. Kejadian resesi banjir-banjir terpilih Sinking Stream

Kedungbuntung

Gambar 4.4.b. Kejadian resesi banjir-banjir terpilih Sinking Stream

Kedungbuntung 61

Gambar 4.5. Fluktuasi aliran dasar Sinking Stream Kedungbuntung.....................62

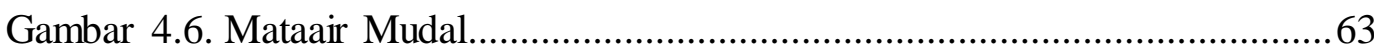

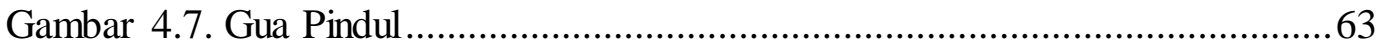

Gambar 4.8. Rating curve Gua Pindul.................................................................65

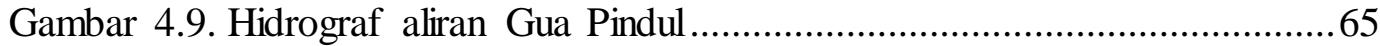

Gambar 4.10.a. Kejadian resesi banjir-banjir terpilih Gua Pindul........................67

Gambar 4.10.b. Kejadian resesi banjir-banjir terpilih Gua Pindul.........................68

Gambar 4.11. Fluktuasi aliran dasar Gua Pindul................................................69

Gambar 4.12. Prosentase aliran dasar bulanan Gua Pindul dan Sinking Stream

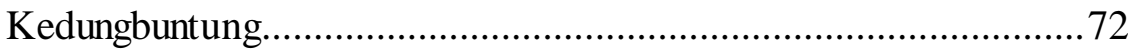

Gambar 4.13. PAD setiap kejadian banjir Gua Pindul dan Sinking Stream

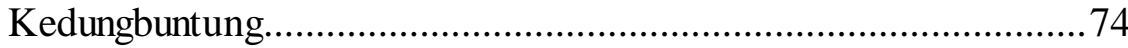

Gambar 4.14.a. Hidrograf banjir dan hyetograf terpilih awal musim hujan di Sinking Stream Kedungbuntung .75

Gambar 4.14.b Hidrograf banjir dan hyetograf terpilih akhir musim hujan di Sinking Stream Kedungbuntung ............................................. 74

Gambar 4.15. Korelasi parsial karakteristik hujan dengan debit puncak di Sinking

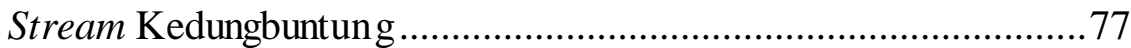


Gambar 4.16.a. Hidrograf banjir dan hyetograf terpilih awal musim hujan di Gua Pindul. .79

Gambar 4.16.b. Hidrograf banjir dan hyetograf terpilih akhir musim hujan di Gua

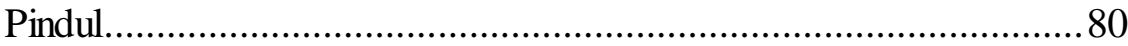

Gambar 4.17. Korelasi parsial karakteristik hujan dengan debit puncak di Gua

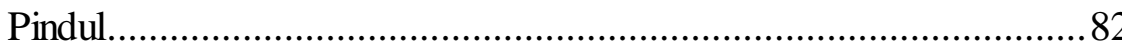

Gambar 4.18. Grafik cross-correlation Gua Pindul dan Kedungbuntung ..............85

Gambar 4.19. Grafik phase functions Gua Pindul dan Kedungbuntung .................86

Gambar 4.20. Grafik cross-amplitude Gua Pindul................................................8 87

Gambar 4.21. Grafik cross-amplitude Kedungbuntung .......................................8 87

Gambar 4.22. Grafik gain functions Gua Pindul................................................ 88

Gambar 4.23. Grafik gain functions Kedungbuntung ........................................ 88

Gambar 4.24. Grafik auto-correlation Gua Pindul dan Kedungbuntung...............89

Gambar 4.25. Grafik spectral-density Gua Pindul dan Kedungbuntung................90 


\section{DAFTAR LAMPIRAN}

Lampiran 1. Perhitungan konstanta resesi Gua Pindul 100

Lampiran 2. Perhitungan konstanta resesi Sinking Stream Kedungbuntung

Lampiran 3. Perhitungan hujan efektif Gua Pindul. 122

Lampiran 4. Perhitungan hujan efektif Sinking Stream Kedungbuntung... 149 


\section{BAB I \\ PENDAHULUAN}

\subsection{Latar Belakang}

Karst merupakan bentanglahan dengan ciri khas aliran permukaan yang langka dan sering ditemukannya sungai bawah tanah (White, 1988; Ford dan Williams, 1989). Goldscheider dan Drew (2007) mengistilahkan karst sebagai suatu sistem yang sulit diprediksi. Karst memiliki area yang luas dari permukaan bumi yang tidak terselimuti es dan $20-25 \%$ populasi dunia bergantung dari air yang disimpannya (Ford dan Williams, 1989). Karena keunikan dan tingginya nilai karst seperti yang dijelaskan diatas, pengetahuan mengenai perilaku atau karakteristik hidrologi karst menjadi penting.

Adanya berbagai tipe aliran (diffuse, fissure, dan conduit) menjadikan metode karakterisasi akuifer yang pada umumnya dikenal, seperti pengukuran transmisibilitas dan hydraulic conductivity, sulit diterapkan (Ford dan Williams, 1989; Gillieson, 1996). Batuan penyusun karst yang mampu menyimpan air menjadikannya didefinisikan sebagai akuifer. Berdasarkan tipe alirannya, White (1969) dan Atkinson (1977) mengklasifikasikan akuifer karst sebagai aliran diffuse (aliran laminar, mengalir melalui pori-pori homogen) dan aliran conduit (aliran turbulen, mengalir melalui lorong perpipaan). Atkinson (1985) memberikan konsep baru mengenai adanya tipe aliran fissure yang mengalir melalui rekahan batuan. Sementara itu, Smart dan Hobbs (1986) memberikan konsep "skema 3-dimensi" yang mencakup tipe imbuhan, tipe simpanan, dan tipe aliran.

Terminologi "sistem drainase karst" diperkenalkan oleh Gillieson (1996) untuk menjelaskan kekompleksan akuifer karst yang dijelaskan di atas. Sistem ini mencakup seluruh bentangalam karst yang dibedakan menjadi lapisan atas (epikarst) dan lapisan bawah (endokarst). Karakterisasi akuifer pada bentanglahan karst dilakukan pada kedua lapisan sistem drainase karst (lapisan epikarst dan endokarst). Oleh karena itu, penelitian ini menggunakan konsep sistem drainase karst untuk mengkaji dinamika hidrologi karst. 
Sistem Drainase Karst Pindul merupakan salah satu bentanglahan karst yang secara administrasi berada di Kecamatan Karangmojo, Kabupaten Gunungkidul. Menurut fisiografi Bemmelen (1949), sistem ini terletak di Basin Wonosari. Sistem Pindul pada Gambar 1.1 menjadi menarik diteliti karena adanya dua tipe akuifer karst (aliran diffuse dan conduit) (Agniy, 2016). Sistem diffuse dicirikan dengan batuan berpori-pori homogen yang dibuktikan dengan dapat dilakukannya pumping test dan pembuatan peta flownet oleh Agniy (2016). Sistem conduit dibuktikan dengan adanya gua-gua yang saling terhubung (Haryono, 2014) (Gambar 1.1).

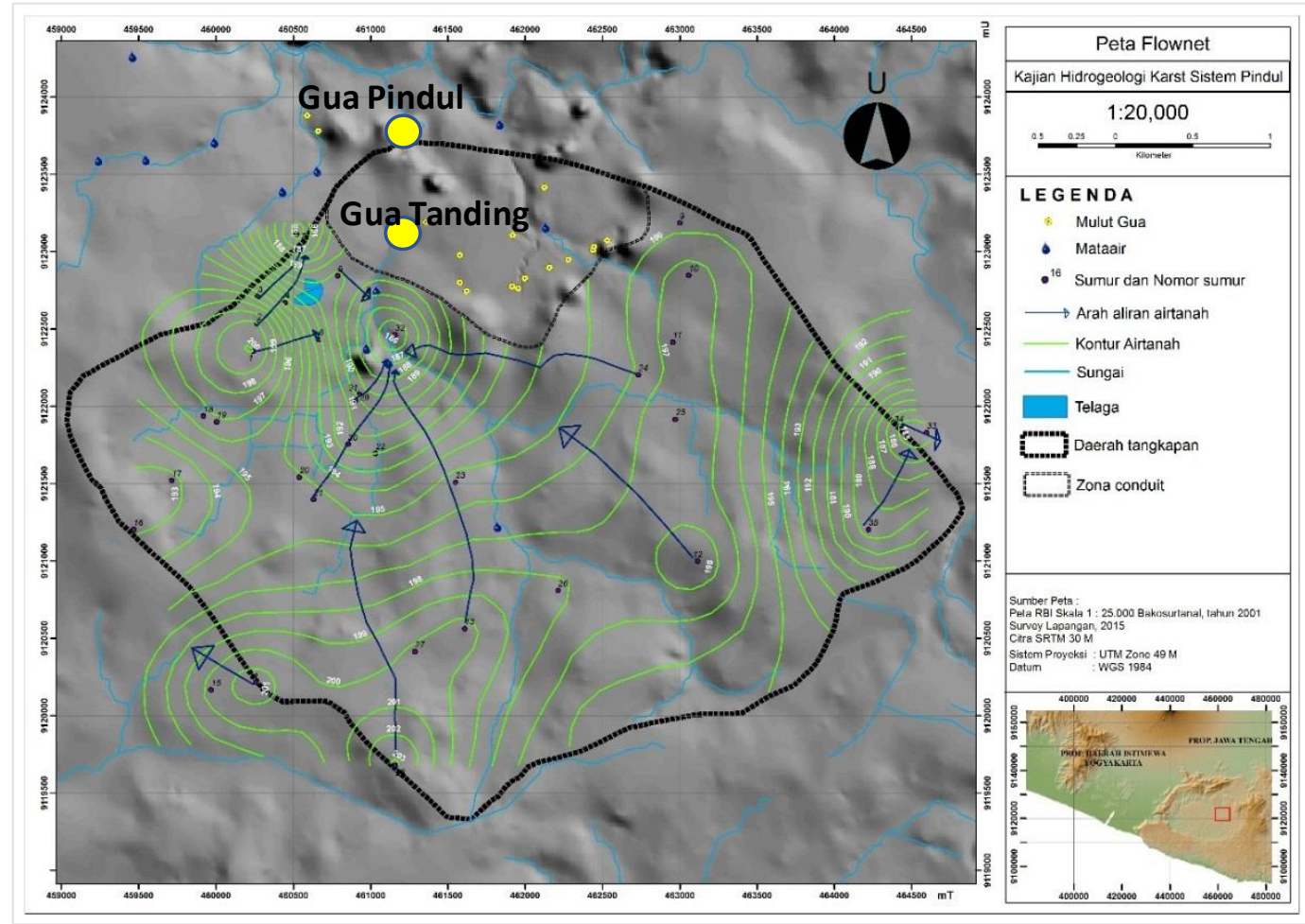

Gambar 1.1. Sistem Drainase Karst Pindul (Agniy, 2016)

Gua Pindul dan Gua Tanding merupakan obyek wisata yang menjadi ikon pada Sistem Drainase Karst Pindul (Gambar 1.2). Wisata gua tersebut mampu menarik sejumlah 122.423 wisatawan dan menyumbang 50\% dari total Pendapatan Asli Daerah (PAD) sektor pariwisata pada periode 2012-2013 (Musadad, 2014). Gambar 1.1 menunjukkan bahwa obyek wisata Gua Pindul terletak pada outlet sistem karst dan Gua Tanding terletak tepat setelah Sinking Stream Kedungbuntung. Posisi kedua obyek tersebut menjadikannya rawan terhadap banjir yang membahayakan wisatawan. 

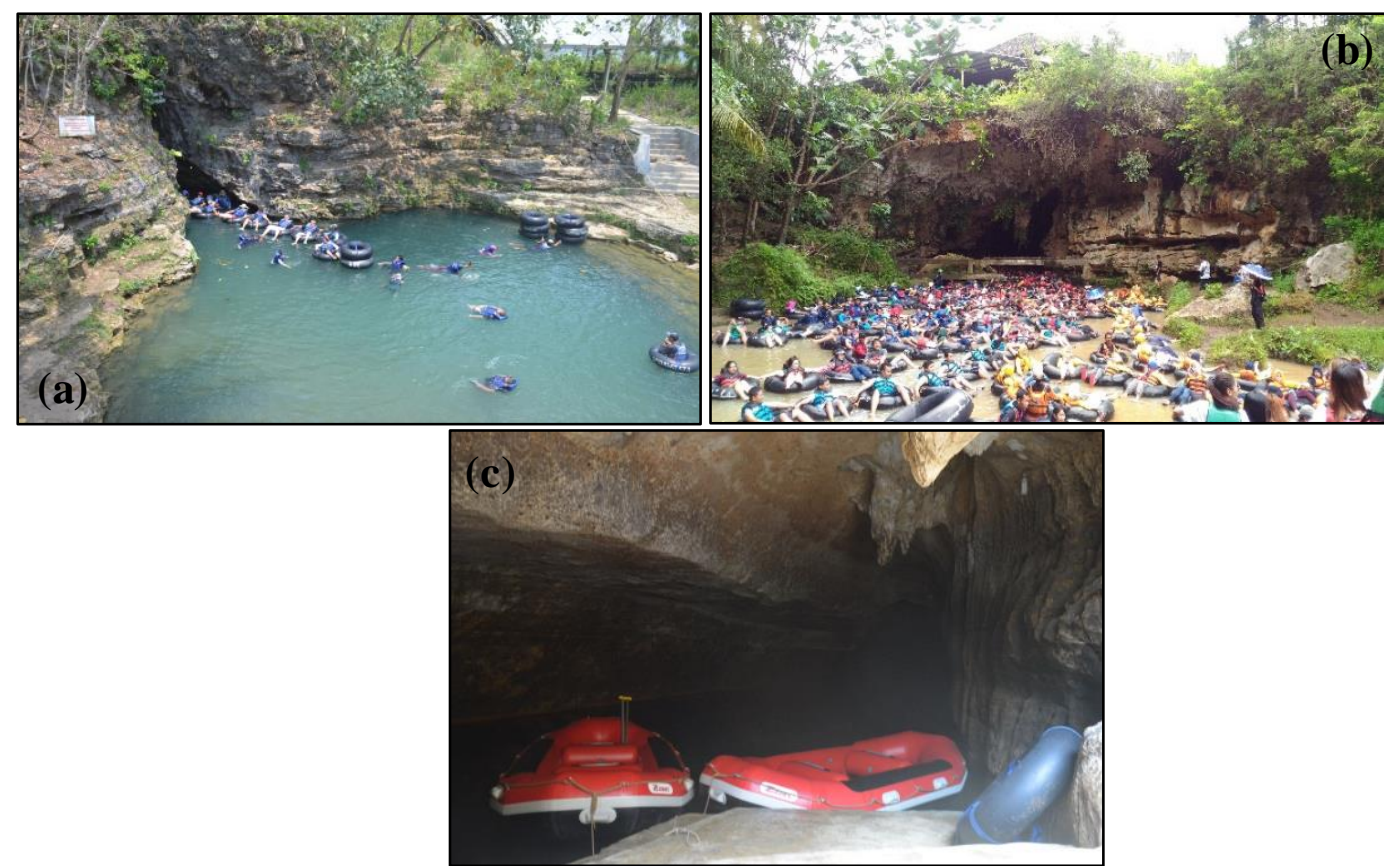

Gambar 1.2. Obyek wisata di Sistem Pindul: (a) pintu keluar Gua Pindul, (b) wisatawan memadati Gua Pindul, (c) wisata perahu Gua Tanding

Selain itu, Peta Penggunaan Lahan (Gambar 3.9) menunjukkan dominannya permukiman dan lahan pertanian. Kedua aktifitas tersebut tentunya bergantung pada ketersediaan air di Sistem Drainase Karst Pindul. Oleh karena itu, pemahaman mengenai perilaku Sistem Drainase Karst Pindul kian menjadi penting mengingat intensifnya aktifitas manusia. Penelitian ini akan mengkaji karakteristik Sistem Drainase Karst Pindul yang mencakup perilaku pelepasan komponen aliran, perilaku banjir, dan respons debit aliran terhadap hujan.

\subsection{Rumusan Masalah}

Seiring aktifitas manusia yang intensif memanfaatkan Sistem Drainase Karst Pindul, Pemerintah Kabupaten Gunungkidul mulai menyusun dokumen AMDAL (Analisis Mengenai Dampak Lingkungan) pada bulan Juni tahun 2016. Dokumen legal ini diharapkan mampu menjadi referensi pengelolaan yang tepat terhadap kawasan Sistem Pindul. Permasalahan yang muncul kemudian adalah belum adanya penelitian yang mengkaji mengenai perilaku hidrologi kawasan ini. Oleh karena itu, permasalahan-permaslahan penelitian dapat disusun sebagai berikut: 
1. Bagaimana variasi spasial dan temporal sifat aliran Sistem Drainase Karst Pindul yang tercermin dari pelepasan komponen aliran dan prosentase aliran dasar?;

2. Bagaimana karakteristik banjir Sistem Drainase Karst Pindul ?;

3. Bagaimana perilaku Sistem Drainase Karst Pindul dalam merespons curah hujan ?

Untuk menjawab pertanyaan-pertanyaan penelitian diatas, tiga metode untuk mengkararakterisasi sistem drainase karst dilakukan. Perhitungan konstanta resesi dan pemisahan aliran dasar dilakukan untuk menjawab permasalahan pertama. Permasalahan kedua dijawab dengan menganalisis parameter hidrograf banjir dan karakteristik hujan. Time series analysis digunakan untuk menjawab permasalahan ketiga. Berdasarkan latar belakang dan rumusan masalah diatas, penelitian ini memiliki judul "Variasi Spasial dan Temporal Sifat Aliran, Perilaku Banjir, dan Respons Debit Aliran Terhadap Curah Hujan di Sistem Drainase Karst Pindul".

\subsection{Tujuan Penelitian}

Tujuan penelitian ini secara spesifik dijabarkan seperti berikut:

1. menemukenali variasi spasial dan temporal dari pelepasan komponen aliran dan prosentase aliran dasar Sistem Drainase Karst Pindul.

2. menemukenali karakteristik banjir Sistem Drainase Karst Pindul.

2. menemukenali perilaku Sistem Drainase Karst Pindul dalam merespons curah hujan.

Untuk mencapai tujuan tersebut, sasaran dari penelitian adalah: (1) fluktuasi debit aliran, (2) prosentase aliran dasar, (3) perilaku resesi banjir, (4) hubungan debit aliran dengan curah hujan, dan (5) perilaku banjir.

\subsection{Manfaat Penelitian}

Penelitian mengenai karakterisasi Sistem Drainase Karst Pindul dapat memberikan manfaat untuk ilmu pengetahuan dan manfaat secara praktis. Manfaat tersebut dapat dijabarkan sebagai berikut:

1. Manfaat untuk ilmu pengetahuan: 
a. Memberi pengetahuan baru mengenai variasi spasial dan temporal perilaku sifat aliran, perilaku banjir, dan respons sistem karst terhadap hujan di Sistem Drainese Karst Pindul yang secara fisiografis berada di Basin Wonosari.

b. Data curah hujan dan debit aliran yang tercatat selama penelitian dapat digunakan untuk berbagai kepentingan.

2. Manfaat praktis:

a. Karakteristik sifat aliran dan hubungan debit aliran dengan curah hujan dapat digunakan sebagai landasan pengelolaan sumberdaya air di Sistem Drainase Karst Pindul.

b. Perilaku banjir dapat digunakan untuk merancang early warning system yang berguna bagi kepentingan pariwisata gua di Sistem Drainase Karst Pindul.

\subsection{Tinjauan Pustaka}

\subsubsection{Konsep Karst dan Karstifikasi}

Karst merupakan suatu medan yang memiliki kondisi hidrologi khas, seperti minimnya sungai permukaan dan terbentuknya sungai bawah tanah (Ford dan Williams, 1989). Ciri khas diatas disebabkan oleh adanya material batuan yang mudah larut dan memiliki porositas sekunder. Adanya batuan mudah larut yang tersingkap di permukaan menjadikan proses pelarutan kimia berlangsung intens if (White, 1988). Ciri khas bentanglahan karst menurut White (1988), yaitu: (1) adanya cekungan tertutup dengan berbagai ukuran dan bentuk, (2) aliran permukaan yang langka, (3) adanya sistem perguaan dan drainase bawah permukaan.

Terbentuknya bentanglahan karst tidak dapat dilepaskan dari proses pembentukannya yang disebut karstifikasi. Menurut Bogli (1980), proses karstifikasi berawal dari air hujan yang jatuh ke permukaan sehingga terjadi proses fisika dan kimia yang menyebabkan perpindahan massa dan reaksi antara fase udara, air, dan batuan. Sistem perpindahan massa dan reaksi kemudian dikenal dengan sistem $\mathrm{CO}_{2}-\mathrm{H}_{2} \mathrm{O}-\mathrm{CaCO}_{3}$. Proses karstifikasi secara sederhana dijelaskan oleh Haryono dan Adji (2004) seperti berikut:

$$
\mathrm{CaCO}_{3}+\mathrm{H}_{2} \mathrm{O}+\mathrm{CO}_{2} \longrightarrow \mathrm{Ca}^{2+}+2 \mathrm{HCO}_{3}^{-}
$$


Labih lanjut lagi, Haryono dan Adji (2004) menyatakan bahwa karstifikasi dipengaruhi oleh adanya faktor pengontrol dan pendorong. Terjadinya proses karstifikasi ditentukan oleh keberadaan faktor pengontrol, sedangkan kecepatan dan hasil bentukan karstifikasi ditentukan oleh keberadaan faktor pendorong. Kedua faktor karstifikasi tersebut dapat dilihat pada Tabel 1.1.

Tabel 1.1 Faktor pengontrol dan pendorong proses karstifikasi (Haryono dan Adji, 2004)

\begin{tabular}{ll}
\hline Faktor Pengontrol & Faktor Pendorong \\
\hline $\begin{array}{l}\text { Batuan dengan karakteristik mudah larut, } \\
\text { kompak, dan tebal. }\end{array}$ & Temperatur \\
Curah hujan yang cukup (>250 mm/tahun) & Penutup lahan dan aktivitas organisme \\
& \\
$\begin{array}{l}\text { Batuan tersingkap pada ketinggian yang } \\
\text { memungkinkan perkembangan drainase secara } \\
\text { vertikal. }\end{array}$ & \\
\hline
\end{tabular}

Adanya kedua faktor dalam karstifikasi menjadikan bentukan-bentukan karst bervariasi. Indonesia memiliki kawasan karst sebesar $20 \%$ dari wilayahnya (Balazs, 1968 dalam Adji 2009). Salah satu kawasan karst yang memiliki hubungan dengan wilayah penelitian ini adalah Karst Gunungsewu. Menurut Sweeting (1972), Karst Gunungsewu dikategorikan sebagai kegelkarst/kerucut karst yang dicirikan oleh bukit-bukit yang saling terhubung. Haryono dan Day (2004) mendetailkan klasifikasi diatas dengan mengklasifikasikan Karst Gunungsewu menjadi tiga (Gambar 1.3), yaitu:

1. Labyrinth-cone karst dicirikan dengan ngarai memanjang yang berbentuk kerucut. Bentukan ini terletak di tengah kawasan Karst Gunungsewu. Bentukan ini disusun oleh batugamping keras dan tebal yang mengalami deformasi intensif.

2. Polygonal karst dicirkan dengan bentukan kerucut karst yang padat pada suatu area sehingga terbentuk cockpit (dataran karst yang berbentuk bintang). Bentukan ini terletak di kawasan Karst Gunungsewu sebelah barat. Material penyusun polygonal karst berupa batugamping keras namun memiliki perlapisan yang tipis.

3. Residual cone karst dicirikan dengan kerucut karst yang saling terisolasi/tersebar diantara dataran karst. Bentukan ini terletak di sebalah 
utara kawasan Karst Gunungsewu. Material penyusun residual cone karst berupa batuan gamping yang lebih lunak dan porous dibanding dua bentukan yang lain.

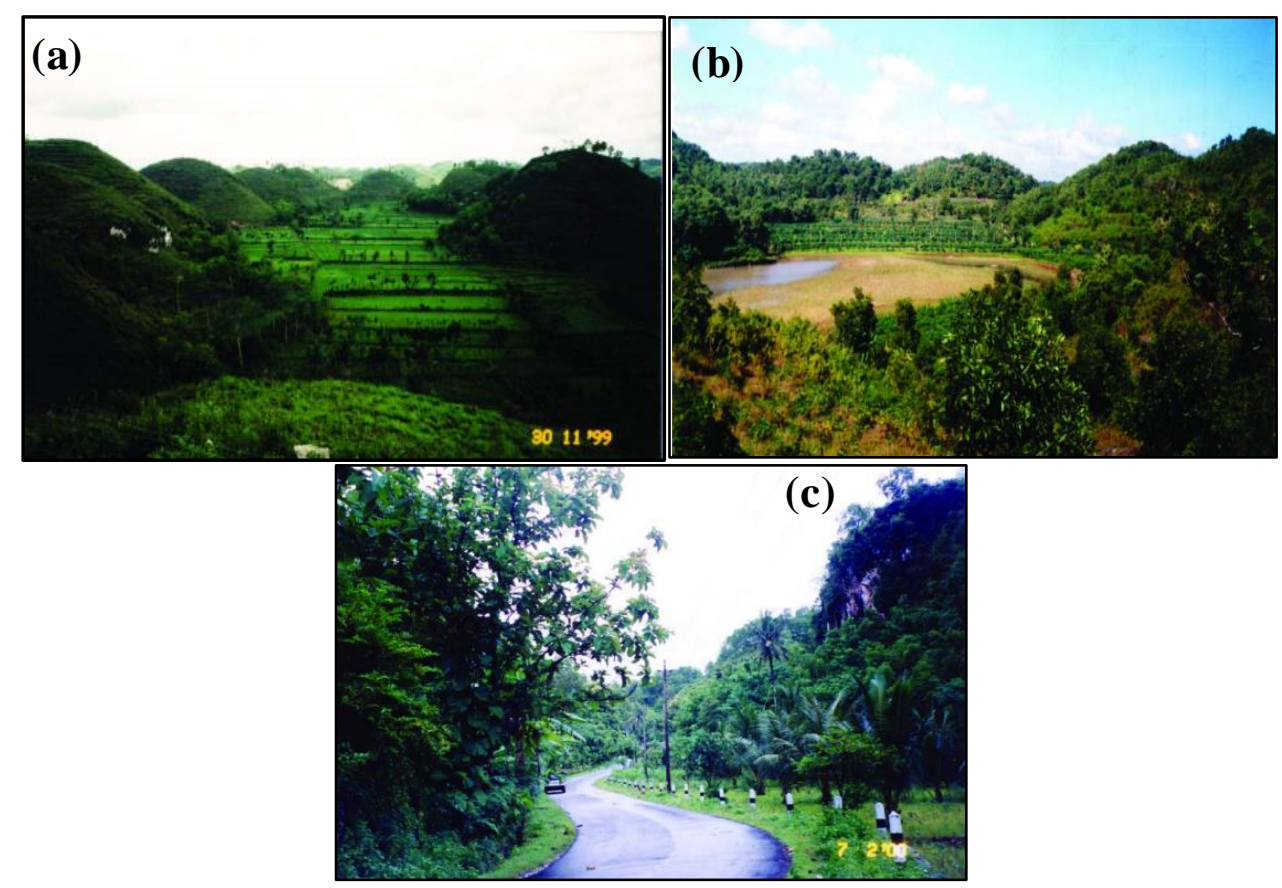

Gambar 1.3. Klasifikasi Karst Gunungsewu menurut Haryono dan Day (2004):

(a) labyrinth-cone karst, (b) polygonal karst, (c) residual cone karst

\subsubsection{Konsep Sistem Drainase Karst}

Gillieson (1996) menjelaskan bahwa sistem drainase karst merupakan kesatuan hidrologis yang terdiri dari zona permukaan (epikarst) dan bawah permukaan (endokarst). Zonasi tersebut didasarkan pada perilaku hidrologi, seperti cara melalukan air dan kandungan kimia pada air. Tabel 1.2 menjelaskan konsep sistem drainase karst menurut Gillieson (1996).

Tabel 1.2. Zonasi sistem drainase karst (Gillieson, 1996)

\begin{tabular}{ll}
\hline Epikarst & Endokarst \\
\hline $\begin{array}{l}\text { Cutaneous zone: tanah, vegetasi, lapisan } \\
\text { permukaan. }\end{array}$ & Vadose Zone: zona tidak jenuh air \\
Subcutaneous zone: bahan kasar tanah, rekahan & Phereatic zone: zona jenuh air \\
\hline
\end{tabular}

Cutaneous merupakan lapisan paling atas yang dapat berupa tanah atau vegetasi. Hujan yang jatuh pada lapisan ini akan mengalami intersepsi atau 
infiltrasi. Subcutaneous berada di bawah lapisan cutaneous yang dicirikan dengan adanya bahan kasar tanah dan rekahan-rakahan batuan.

Williams (1983) menjelaskan bahwa kedua lapisan diatas sangat penting dalam siklus hidrologi karst. Subcutaneous memiliki permeabilitas tinggi yang terbentuk akibat adanya proses solusional yang belum terlalu intensif. Lapisan ini akan menahan air dalam jangka waktu lama, kemudian melepaskannya perlahanlahan ke lapisan vadose atau langsung ke lapisan phreatic. Permeabilitas tersebut akan menurun seiring bertambahnya kedalaman akibat proses kimia yang berkurang. Ford dan Williams (1989) mengabaikan lapisan cutaneous dan menyamakan subcutaneous dengan epikarst (Gambar 1.4).

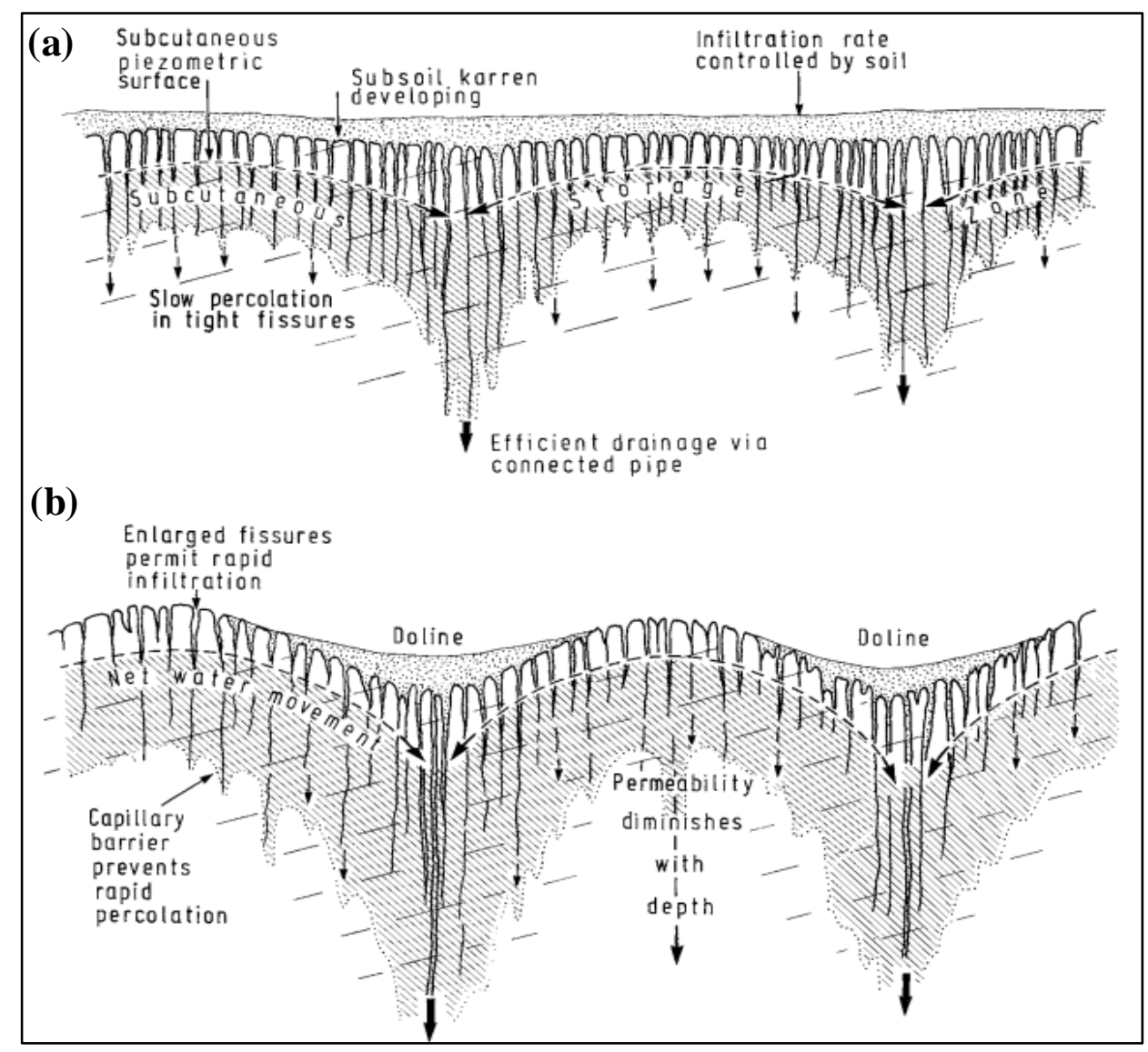

Gambar 1.4. Lapisan subcutaneous dan perkembangannya: (a) awal mula lapisan subcutaneous, (b) perkembangan lapisan seiring berjalannya waktu akibat proses solusional, permeabilitas semakin kecil seiring bertambahnya kedalaman (Ford dan Williams, 1989) 


\subsubsection{Klasifikasi Sistem Drainase Karst}

\section{a. Konseptual Model Imbuhan Sistem Drainase Karst}

Karst merupakan formasi batuan yang tergolong sebagai akuifer. Definisi akuifer adalah suatu formasi batuan yang mampu meloloskan air dalam jumlah signifikan (Todd, 1980). Hal tersebut sesuai dengan salah satu karakteristik khas yang dipaparkan oleh White (1988), yaitu karst memiliki sistem perguaan dan drainase bawah permukaan. Meskipun demikian, akuifer karst memiliki keunikan tersendiri berupa rongga batuan yang terkadang homogen dan terkadang membentuk sistem perpipaan. Karena keunikan tersebut, White $(1988,2002)$ membuat suatu konseptual model mengenai imbuhan pada sistem drainase karst. Konsep ini utamanya dijelaskan melalui empat komponen imbuhan karst (Gambar 1.5), yaitu:

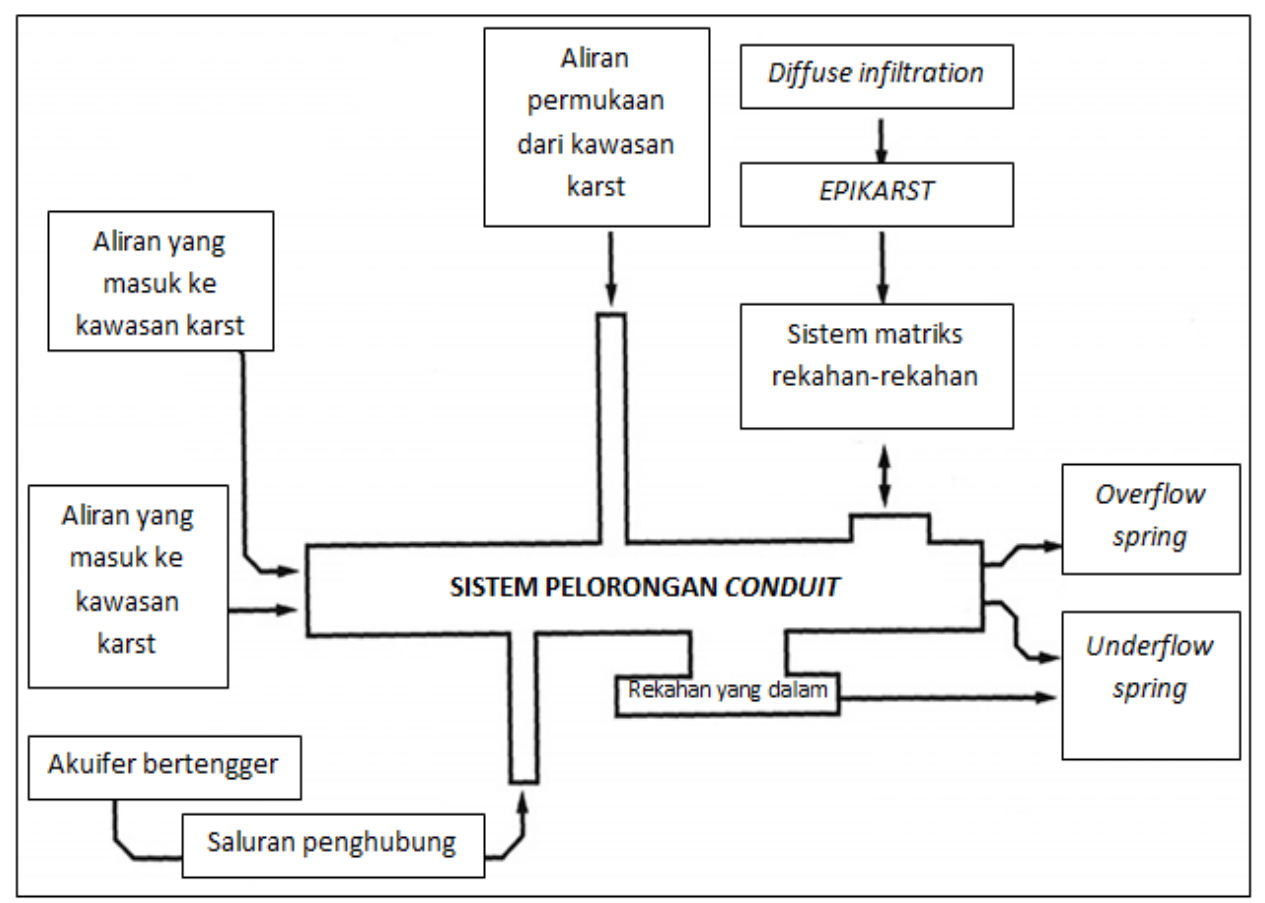

Gambar 1.5. Konseptual model aliran air pada sistem drainase karst (White, 1988, 2002)

1. Allogenic recharge merupakan aliran permukaan yang mengimbuh akuifer karst melalui sinkhole atau ponor. Imbuhan ini biasa disebut sebagai sungai yang tertelan. Allogenic recharge langsung mengimbuh sistem pelorongan conduit. 
2. Internal runoff merupakan imbuhan dari air hujan yang langsung mengimbuh sistem pelorongan conduit melalui sinkhole atau ponor.

3. Diffuse infiltration merupakan imbuhan dari air hujan yang tersimpan dalam waktu cukup lama pada lapisan epikarst. Air simpanan ini kemudian mengalir perlahan-lahan ke bawah melalui rekahan atau rongga sebelum mencapai sistem pelorongan conduit.

4. Imbuhan dari akuifer bertengger merupakan imbuhan yang berasal dari lapisan semipermeabel yang juga disebut sebagai akuifer bertengger. Simpanan air pada akuifer ini akan mencapai sistem pelorongan conduit melalui saluran penghubung, seperti rongga batuan dan rekahan.

\section{b. Tipe Aliran Diffuse, Fissure, dan Conduit}

Klasifikasi sistem drainase karst pertama kali dilakukan oleh White (1969) yang membagi sistem karst menjadi aliran diffuse dan conduit berdasarkan tipe alirannya. Aliran conduit selanjutnya dibedakan menjadi akuifer bebas dan tertekan (Gambar 1.6). Model ini dibuktikan oleh penelitian Atkinson (1977) di Mendip Hills (Sout West English). Penjelasan klasifikasi menurut White (1969) adalah sebagai berikut:

1. Diffuse flow aquifer terbentuk pada formasi batuan yang aktivitas pelarutannya mengalami hambatan oleh jenis batuan yang resisten (contohnya dolomit). Air mengalir pada rongga-rongga kecil atau rekahan pada batuan sehingga sifatnya homogen seperti akuifer pada umumnya. Aliran akan keluar melalui beberapa mataair atau rembesan dengan debit kecil.

2. Free flow aquifer terbentuk pada formasi batuan yang memiliki tingkat pelarutan dan ketebalan yang membentang dari permukaan tanah hingga lapisan dasar (base level). Oleh karena itu, aktivitas pelarutan menyebabkan terbentuknya rongga-rongga kecil dan rekahan (seperti pada diffuse flow aquifer) serta adanya perpipaan (conduit). Aliran pada akuifer ini akan keluar melalui mataair tunggal dengan debit yang besar. 
3. Confined flow aquifer terbentuk akibat adanya formasi batuan kedap air atau memiliki permeabilitas rendah yang berada diatas akuifer karst. Akuifer karst akan memiliki sifat artesis atau akuifer tertekan biasa (sandwich aquifer).
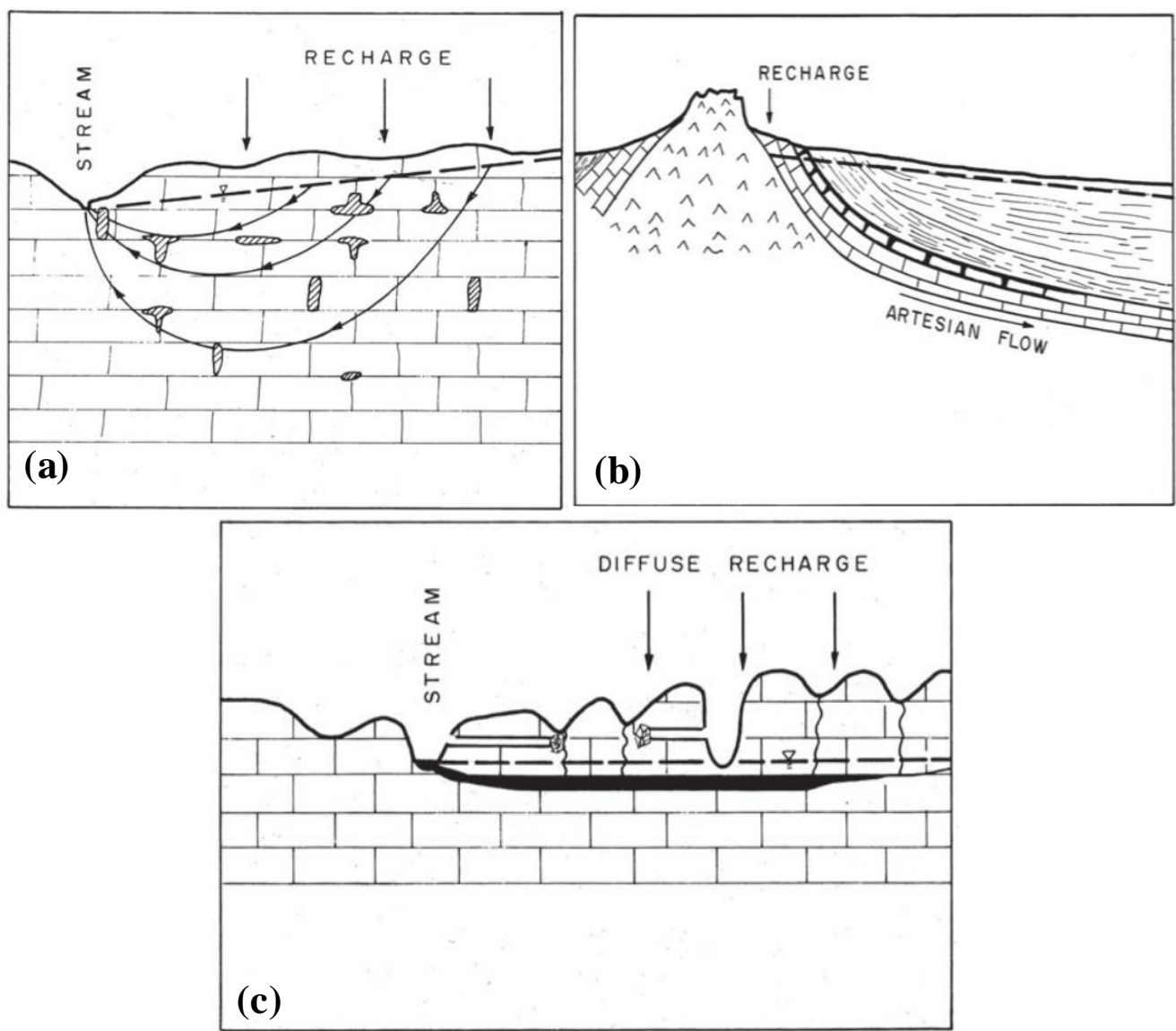

Gambar 1.6. Klasifikasi sistem drainase karst menurut White (1969): (a) diffuse flow aquifer, (b) confined flow aquifer, (c) free flow aquifer

Atkinson (1985) selanjutnya menemukan bahwa pembagian sistem karst menjadi diffuse dan conduit terlalu menyederhanakan. Terdapat sifat aliran karst lain diantara keduanya yang kemudian disebut sebagai fissure. Pada dasarnya, ketiga aliran ini tidak pernah berdiri sendiri pada suatu sistem drainase karst (Gambar 1.7).

\section{c. Konsep Skema 3-Dimensi Sistem Drainase Karst}

Smart dan Hobbs (1986) menambahkan komponen imbuhan dan simpanan akuifer disamping sifat aliran. Ketiga komponen ini selanjutnya disebut sebagai konsep 3-dimensi (Gambar 1.8). Komponen imbuhan terdiri dari imbuhan 
terkonsentrasi dan menyebar, komponen simpanan terdiri dari simpanan besar dan kecil, serta komponen aliran terdiri dari conduit, fissure dan diffuse.

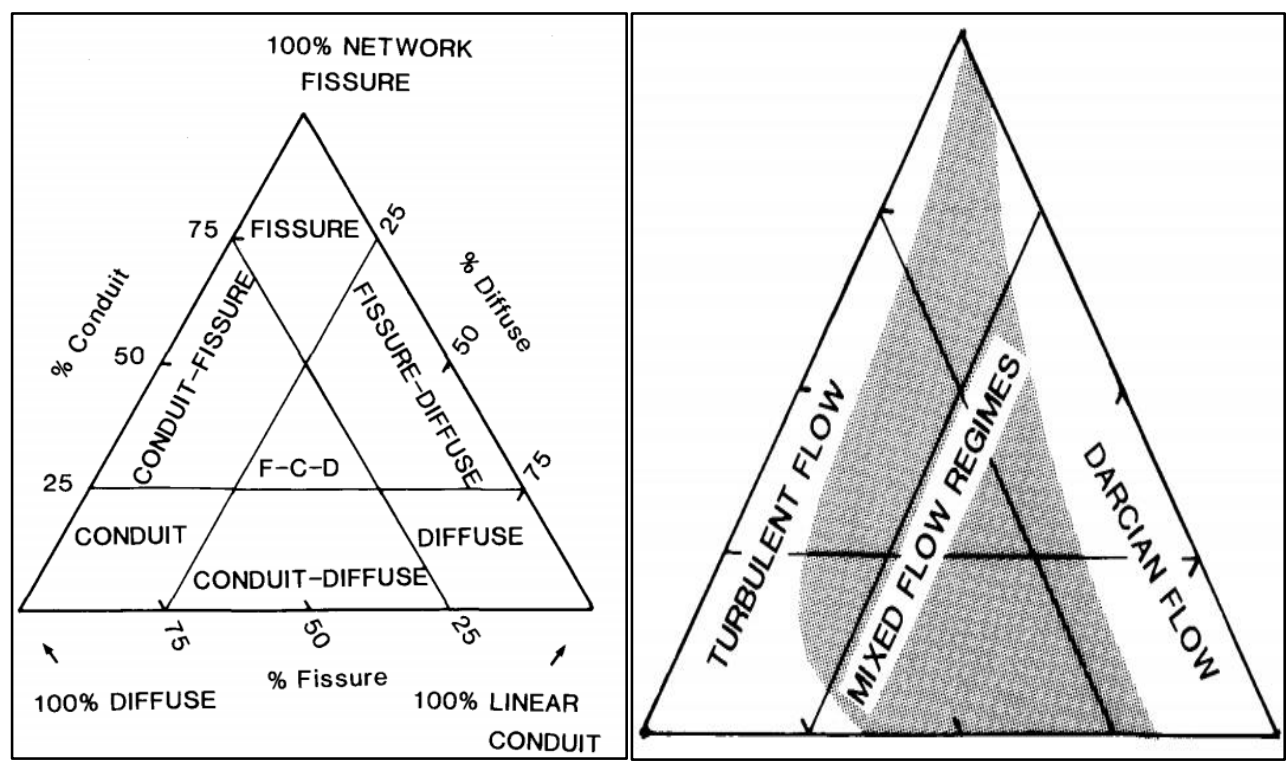

Gambar 1.7. Skema tiga sifat aliran pada suatu sistem drainase karst (Atkinson, 1985)

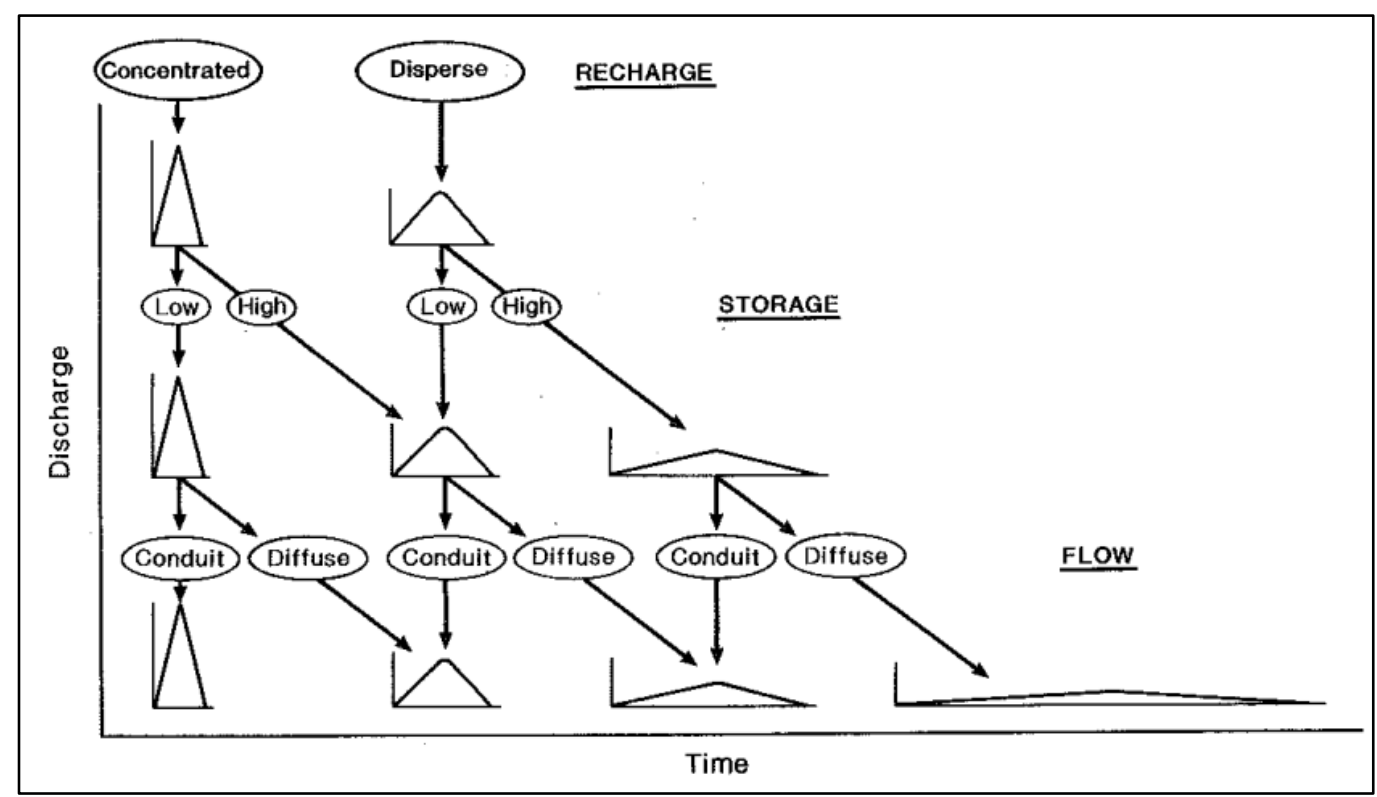

Gambar 1.8. Hubungan imbuhan, simpanan, dan sifat aliran yang akan menghasilkan perbedaan hidrograf aliran pada mataair karst

(Smart dan Hobbs, 1986)

\subsubsection{Karakterisasi Sistem Drainase Karst}

Sistem karst yang memiliki triple-porosity (diffuse-fissure-conduit), seperti yang dijelaskan di atas, menjadikan berbagai model yang umum digunakan untuk 
mengkarakterisasi akuifer menjadi tidak berlaku. Hal ini karena model-model tersebut didasarkan pada Hukum Darcy yang menganggap aliran pada akuifer laminar. Ford dan Williams (1989) menyatakan bahwa terdapat lima metode yang saling terkait untuk melakukan karakterisasi akuifer/sistem drainase karst (Tabel 1.3), yaitu: (1) estimasi kesetimbangan air, (2) borehole analysis, (3) analis is hidrograf mataair, (4) water tracing, (5) pemodelan akuifer. Sementara itu, Adji dan Cahyadi (2016) memberi penjelasan mendetail mengenai analisis hidrograf maatair untuk karakterisasi sistem drainase karst, diantaranya adalah: (1) analis is parameter hidrograf banjir, (2) perhitungan konstanta resesi, (3) pemisahan aliran dasar, (4) analisis respons debit terhadap hujan, (5) perhitungan derajat perkembangan akuifer karst, (6) analis is hidrokemograf.

Tabel 1.3. Model karakterisasi akuifer karst pada setiap kondisi yang berbeda (Ford dan Williams, 1989)

\begin{tabular}{|c|c|c|c|c|}
\hline $\begin{array}{l}\text { Tipe } \\
\text { Aliran } \\
\end{array}$ & $\begin{array}{l}\text { Kondisi Batas } \\
\text { Daerah Tangkapan }\end{array}$ & $\begin{array}{l}\text { Karakteris tik } \\
\text { Akuifer }\end{array}$ & Skala Pengukuran & Cara Karakterisasi \\
\hline \multirow[t]{2}{*}{ Diffuse } & tidak terbatas, luas & $\begin{array}{l}\text { confined, } \\
\text { unconfined }\end{array}$ & $\begin{array}{l}\text { spesifik lokasi/ } \\
\text { titik }\end{array}$ & borehole dillution \\
\hline & kedap air, bocoran & $\begin{array}{l}\text { confined, } \\
\text { unconfined }\end{array}$ & lokal & borehole recharge \\
\hline Fissure & $\begin{array}{l}\text { atas dan bawah } \\
\text { permukaan }\end{array}$ & $\begin{array}{l}\text { homogen, } \\
\text { heterogen }\end{array}$ & $\begin{array}{l}\text { regional, cekungan } \\
\text { airtanah }\end{array}$ & $\begin{array}{l}\text { borehole pumping, } \\
\text { recharge-response } \\
\text { modelling }\end{array}$ \\
\hline Conduit & $\begin{array}{l}\text { akuifer diffuse, } \\
\text { sinking stream, } \\
\text { allogenic recharge }\end{array}$ & $\begin{array}{l}\text { isotropic, } \\
\text { anisotropic }\end{array}$ & $\begin{array}{l}\text { DTA yang } \\
\text { diketahui, belum } \\
\text { diketahui }\end{array}$ & $\begin{array}{l}\text { recharge-response } \\
\text { modelling,water } \\
\text { budget, spring } \\
\text { hydrograph \& } \\
\text { chemograph, akuifer } \\
\text { modelling }\end{array}$ \\
\hline
\end{tabular}

\subsection{Penelitian Terdahulu}

Penelitian mengenai karakterisasi sistem drainase karst telah beberapa kali dilakukan di fisiografi Karst Gunungsewu. Perbandingan antara penelitian lain dengan penelitian ini dapat dilihat pada Tabel 1.4. Adji, dkk (2006) di sistem SBT Bribin; Adji (2009) di sistem SBT Bribin dengen pendekatan yang berbeda; Misqi (2010) di Matatair Beton, SBT Seropan, dan SBT Bribin; Oktama (2014) di Mataair Ngeleng; dan Bahtiar (2014) di Mataair Ngeleng dengan pendekatan yang berbeda. Penelitian ini akan mengambil lokasi yang berbeda secara fisiografi dibandingkan penelitian-penenelitian yang disebutkan di atas. Penelitian ini akan dilakukan di 
fisiografi Basin Wonosari tepatnya pada Sistem Drainase Karst Pindul (Gambar $3.3)$.

Penelitian mengenai karakterisasi sistem drainase karst belum pernah dilakukan di Sistem Pindul. Penelitian di kawasan karst ini oleh Romza (2016) mengkaji mengenai hidrogeologi karst. Penelitian tersebut juga melakukan karakterisasi sistem drainase karst, namun pengukuran hidrologi tidak dilakukan secara kontinu. Haryono (2014) melakukan penelitian mengenai speleogenesis di kawasan ini. Penelitian tersebut membuktikan bahwa terdapat beberapa gua yang saling terhubung sebelum mengimbuh Gua Pindul (Gambar 3.9).

Secara metode, penelitian ini menggabungkan tiga metode karakterisasi sistem drainase karst, yaitu: (1) perhitungan konstantas resesi dan pemisahan aliran dasar, (2) analisis hubungan debit aliran dengan curah hujan, dan (3) analis is parameter hidrograf banjir dan karakteristik hujan. Raeisi dan Karimi (1997); Karimi, Raesi, dan Zare (2003) melakukan karakterisasi sistem drainase karst berdasarkan hidrogeokimia dan sifat aliran (perhitungan konstanta resesi). Penelitian mengenai hubungan debit aliran dengan curah hujan yang menggunakan time series analysis dilakukan oleh Padilla dan Pulido-Bosch (1995), Rahnemaei; Zare; Nematollahi; Sedghi (2005), Panagopoulus dan Lambarakis (2006), Jemcov dan Petric (2009), Zang; Chen; Chen; Shi (2013). Penelitian yang menggunakan analisis parameter hidrograf banjir dan karakteristik hujan dilakukan oleh Adji (2009) dan Bahtiar (2014).

Tabel 1.4. Perbandingan penelitian terdahulu dengan penelitian ini

\begin{tabular}{|c|c|c|c|c|}
\hline No. & Peneliti, Tahun, Judul & Tujuan Utama & Metode & Hasil \\
\hline 1 & $\begin{array}{l}\text { Padilla dan Pulido-Bosch } \\
\text { (1995), Study of } \\
\text { Hydrographs of Karstic } \\
\text { Aquifers by means of } \\
\text { Correlation and Cross- } \\
\text { Spectral Analysis }\end{array}$ & $\begin{array}{l}\text { Mengetahui } \\
\text { karakteristik } \\
\text { akuifer } \\
\text { berdasarkan } \\
\text { time series } \\
\text { analysis pada } \\
\text { empat akuifer } \\
\text { karst berbeda }\end{array}$ & $\begin{array}{l}\text { Cross- } \\
\text { correlation, } \\
\text { cross-amplitude, } \\
\text { phase functin, } \\
\text { gainfunction, } \\
\text { coherency } \\
\text { function }\end{array}$ & $\begin{array}{l}\text { Akuifer di } \\
\text { Mediterrania } \\
\text { didominasi aliran } \\
\text { diffuse, akuifer di } \\
\text { Pyrenees } \\
\text { didominasi aliran } \\
\text { conduit. }\end{array}$ \\
\hline 2 & $\begin{array}{l}\text { Raeisi dan Karimi (1997), } \\
\text { Hydrochemographs of } \\
\text { Berghan Karst Spring as } \\
\text { Indicators of Aquifer } \\
\text { Characteristics }\end{array}$ & $\begin{array}{l}\text { Mengetahui } \\
\text { karakteristik } \\
\text { akuifer } \\
\text { berdasarkan } \\
\text { hidrogeokimia } \\
\text { dan sifat aliran }\end{array}$ & $\begin{array}{l}\text { Konstanta resesi, } \\
\text { pemis ahan aliran } \\
\text { dasar, } \\
\text { hidrogeokimia, } \\
\text { kemograf, SI, } \\
\text { dan PCO2 }\end{array}$ & $\begin{array}{l}\text { Hidrogeokimia } \\
\text { dan sifat aliran } \\
\text { menunjukkan } \\
\text { bahwa akuifer } \\
\text { karsr bertipe } \\
\text { diffuse } \\
\end{array}$ \\
\hline
\end{tabular}




\begin{tabular}{|c|c|c|c|c|}
\hline No. & Peneliti, Tahun, Judul & Tujuan Utama & Metode & Hasil \\
\hline 3 & $\begin{array}{l}\text { Karimi; Raesi; dan Zare } \\
\text { (2003), Hydrodynamic } \\
\text { Behavior of the Gilan Karst } \\
\text { Spring, West of The Zagros, } \\
\text { Iran }\end{array}$ & $\begin{array}{l}\text { Mengetahui } \\
\text { karakteris tik } \\
\text { akuifer karst } \\
\text { terutama sifat } \\
\text { alirannya }\end{array}$ & $\begin{array}{l}\text { Aspekgeologi, } \\
\text { parameter fisik- } \\
\text { kimia, tes }{ }^{18} \mathrm{O} \\
\text { dan deutrium }\end{array}$ & $\begin{array}{l}\text { Akuifer karst } \\
\text { tergolong sebagai } \\
\text { diffuse }\end{array}$ \\
\hline 4 & $\begin{array}{l}\text { Rahnemaei; Zare; } \\
\text { Nematollahi; Sedghi (2005), } \\
\text { Application ofSpectral } \\
\text { Analysis of Daily Water } \\
\text { Level and Spring } \\
\text { Discharge Hydrographs } \\
\text { Data for Comparing } \\
\text { Physical Characteristics of } \\
\text { Karstic Aquifers }\end{array}$ & $\begin{array}{l}\text { Mengetahui } \\
\text { karakteristik } \\
\text { dual porosity } \\
\text { ( } \mathrm{t} 1 \text { dan } \mathrm{t} 2) \\
\text { melalui time } \\
\text { series analysis } \\
\text { pada empat } \\
\text { akuifer berbeda }\end{array}$ & $\begin{array}{l}\text { Phase Functoins, } \\
\text { Coherency } \\
\text { Functions }\end{array}$ & $\begin{array}{l}\text { Nilai time lag } \\
\text { semakin cepat } \\
\text { pada tingkat } \\
\text { karstifikasi tinggi. }\end{array}$ \\
\hline 5 & $\begin{array}{l}\text { Panagopoulus dan } \\
\text { Lambarakis (2006), The } \\
\text { Contribution ofTime Series } \\
\text { Analysis to The } \\
\text { Study of The Hydrodynamic } \\
\text { Characteristics of } \\
\text { The Karst Systems: } \\
\text { Application on Two Typical } \\
\text { Karst Aquifers of Greece } \\
\text { (Trifilia, Almyros Crete) }\end{array}$ & $\begin{array}{l}\text { Mengetahui } \\
\text { karakteristik } \\
\text { akuifer karst } \\
\text { menggunkan } \\
\text { time series } \\
\text { analysis pada } \\
\text { dua akuifer } \\
\text { berbeda }\end{array}$ & $\begin{array}{l}\text { Auto-correlation, } \\
\text { spectral density, } \\
\text { cross- } \\
\text { correlation, } \\
\text { cross-amplitude, } \\
\text { phase functions, } \\
\text { gain functions, } \\
\text { coherency } \\
\text { functions }\end{array}$ & $\begin{array}{l}\text { Karst Trifilia } \\
\text { didominasi oleh } \\
\text { baseflow, } \\
\text { sedangkan Karst } \\
\text { Almyros } \\
\text { disominasi oleh } \\
\text { quickflow. }\end{array}$ \\
\hline 6 & $\begin{array}{l}\text { Adji; Sudarmadji; Woro, } \\
\text { Hendrayana; Hariadi, } \\
\text { (2006), The Distribution Of } \\
\text { Flood Hydrograph } \\
\text { Recession Constant Of } \\
\text { Bribin } \\
\text { River For Gunung Sewu } \\
\text { Karst Aquifer } \\
\text { Characterization }\end{array}$ & $\begin{array}{l}\text { Mengetahui } \\
\text { karakteristik } \\
\text { akuifer karst } \\
\text { berdasarkan } \\
\text { sifat aliran } \\
\text { secara spasial } \\
\text { dan temporal }\end{array}$ & $\begin{array}{l}\text { Perhitungan } \\
\text { konstanta resesi } \\
\text { dan pemisahan } \\
\text { aliran dasar }\end{array}$ & $\begin{array}{l}\text { Gua Bribin dan } \\
\text { Gua Ngreneng } \\
\text { didominasi sifat } \\
\text { aliran diffuse, } \\
\text { sedangkan Gua } \\
\text { Gilap memiliki } \\
\text { respons aliran } \\
\text { yang paling cepat }\end{array}$ \\
\hline 7 & $\begin{array}{l}\text { Adji, (2009), Variasi } \\
\text { Spasial-Temporal } \\
\text { Hidrogeokimia dan } \\
\text { Sifat Aliran untuk } \\
\text { Karakterisasi Sistem Karst } \\
\text { Dinamis di Sungai bawah } \\
\text { Tanah Bribin, Kabupaten } \\
\text { Gunungkidul DIY }\end{array}$ & $\begin{array}{l}\text { Mengetahui } \\
\text { variasi } \\
\text { temporal- } \\
\text { spasial } \\
\text { komponen } \\
\text { aliran, } \\
\text { hidrogeokimia, } \\
\text { dan sistem karst } \\
\text { dinamis }\end{array}$ & $\begin{array}{l}\text { Pemisahan } \\
\text { komponen } \\
\text { aliran, } \\
\text { konstanta resesi } \\
\text { analisis } \\
\text { kemograf, } \\
\text { analisis } \mathrm{SI}, \mathrm{PCO}_{2}\end{array}$ & $\begin{array}{l}\text { Terdapat variasi } \\
\text { spasial dan } \\
\text { temporal sifat } \\
\text { aliran, kondisi } \\
\text { hidrogeokimia, } \\
\text { dan agerisivitas } \\
\text { di SBT Bribin. } \\
\text { Gua Bribin lebih } \\
\text { didominasi oleh } \\
\text { aliran dasardan } \\
\text { paling agresif } \\
\text { dibandingkan gua } \\
\text { di hulu }\end{array}$ \\
\hline
\end{tabular}




\begin{tabular}{|c|c|c|c|c|}
\hline No. & Peneliti, Tahun, Judul & Tujuan Utama & Metode & Hasil \\
\hline 8 & $\begin{array}{l}\text { Jemcov dan Petric, (2009, } \\
\text { Measured Precipitation vs. } \\
\text { Effective Infiltration and } \\
\text { Their Influence on The } \\
\text { Assessment of Karst Systems } \\
\text { Based on Results of The } \\
\text { Time Series Analysis }\end{array}$ & $\begin{array}{l}\text { Mengetahui } \\
\text { karakteristik } \\
\text { akuifer melalui } \\
\text { time series } \\
\text { analysis dengan } \\
\text { input effective } \\
\text { infiltration pada } \\
\text { empat akuifer } \\
\text { yang berbeda }\end{array}$ & $\begin{array}{l}\text { Auto-correlation, } \\
\text { spectral density, } \\
\text { cross- } \\
\text { correlation, } \\
\text { cross-amplitude, } \\
\text { phase functions, } \\
\text { gainfunctions, } \\
\text { coherency } \\
\text { functions }\end{array}$ & $\begin{array}{l}\text { Effective } \\
\text { infiltration lebih } \\
\text { akurat digunakan } \\
\text { pada karst dengan } \\
\text { dominasi } \\
\text { baseflow. Hujan } \\
\text { lebih akurat pada } \\
\text { akuifer dengan } \\
\text { dominasi } \\
\text { quickflow. }\end{array}$ \\
\hline 9 & $\begin{array}{l}\text { Misqi, (2010), } \\
\text { Analisis Konstanta Resesi } \\
\text { Sungai Bawah Tanah untuk } \\
\text { Karakterisasi Pelepasan } \\
\text { Komponen Akuifer Karst } \\
\text { (Studi Kasus: Mataair } \\
\text { Beton, Sungai Bawah Tanah } \\
\text { Seropan, dan Sungai Bawah } \\
\text { Tanah Bribin, Kab. } \\
\text { Gunungkidul, Provinsi DIY) }\end{array}$ & $\begin{array}{l}\text { Mengetahui } \\
\text { karakteristik } \\
\text { akuifer karst } \\
\text { berdasarkan } \\
\text { sifat aliran } \\
\text { secara spasial }\end{array}$ & $\begin{array}{l}\text { Perhitungan } \\
\text { konstanta resesi } \\
\text { dan pemisahan } \\
\text { aliran dasar }\end{array}$ & $\begin{array}{l}\text { Nilai tertinggi } \\
\text { konstanta } \\
\text { resesi diffuse } \\
\text { dimiliki } \\
\text { oleh Gua Seropan } \\
\text { dan } \\
\text { yang terkecil } \\
\text { adalah } \\
\text { Gua Toto }\end{array}$ \\
\hline 10 & $\begin{array}{l}\text { Zang; Chen; Chen; Shi, } \\
\text { (2013), Quantifying Time } \\
\text { Lag of Epikarst-Spring } \\
\text { Hydrograph Response to } \\
\text { Rainfall } \\
\text { Using Correlation and } \\
\text { Spectral Analyses }\end{array}$ & $\begin{array}{l}\text { Mengetahui } \\
\text { pengaruh } \\
\text { epikarts } \\
\text { terhadap time } \\
\text { lag dan } \\
\text { menggunakan } \\
\text { time series } \\
\text { analysis pada } \\
\text { dua akuifer } \\
\text { berbeda }\end{array}$ & $\begin{array}{l}\text { Auto-correlation, } \\
\text { spectral density, } \\
\text { cross- } \\
\text { correlation, } \\
\text { cross-amplitude, } \\
\text { phase functions, } \\
\text { gainfunctions, } \\
\text { coherency } \\
\text { functions }\end{array}$ & $\begin{array}{l}\text { Time series } \\
\text { analysis dapat } \\
\text { membedakan } \\
\text { karakteristik } \\
\text { akuifer menjadi } \\
\text { respons jangka } \\
\text { pendek, jangka } \\
\text { mengengah, } \\
\text { jangka panjang, } \\
\text { durasi quickflow } \\
\text { dan baseflow. }\end{array}$ \\
\hline 11 & $\begin{array}{l}\text { Oktama (2014), } \\
\text { Karakterisasi } \\
\text { Akuifer Karst } \\
\text { Mataair Ngeleng } \\
\text { dengan Pendekatan } \\
\text { Variasi Temporal } \\
\text { Sifat Alirandan } \\
\text { Hidrogeokimia }\end{array}$ & $\begin{array}{l}\text { Mengetahui } \\
\text { variasi temporal } \\
\text { sifat aliran, } \\
\text { hidrogeokimia, } \\
\text { dan hubungan } \\
\text { keduanya. }\end{array}$ & $\begin{array}{l}\text { Pemisahan aliran } \\
\text { dasar, konstanta } \\
\text { resesi, kemograf, } \\
\mathrm{SI}, \mathrm{PCO}_{2}\end{array}$ & $\begin{array}{l}\text { Mataair Ngeleng } \\
\text { memiliki sifat } \\
\text { aliran mixed, } \\
\text { yaitu campuran } \\
\text { diffuse dan } \\
\text { conduit. Unsur } \\
\text { terlarut yang } \\
\text { dominan adalah } \\
\text { Ca dan } \mathrm{HCO}_{3}^{-} \text {. }\end{array}$ \\
\hline 12 & $\begin{array}{l}\text { Bahtiar (2014), Kajian } \\
\text { Respons } \\
\text { Debit Mataair } \\
\text { Ngeleng Terhadapa } \\
\text { Curah Hujan untuk } \\
\text { Karakterisasi } \\
\text { Akuifer Karst }\end{array}$ & $\begin{array}{l}\text { Mengetahui } \\
\text { korelasi curah } \\
\text { hujan dengan } \\
\text { debit dan } \\
\text { menganalisis } \\
\text { sifat aliran } \\
\text {. }\end{array}$ & $\begin{array}{l}\text { Cross- } \\
\text { correlation, } \\
\text { konstanta resesi, } \\
\text { pemisahan aliran } \\
\text { dasar }\end{array}$ & $\begin{array}{l}\text { Mataair Ngeleng } \\
\text { memiliki } \mathrm{T}_{\text {lag }} \\
\text { yang cepat dan } \\
\text { sifat aliran } \\
\text { campuran conduit } \\
\text { dengan diffuse. } \\
\text { Simpanan } \\
\text { airtanah } \\
\text { tergolong baik. }\end{array}$ \\
\hline
\end{tabular}




\begin{tabular}{|c|c|c|c|c|}
\hline No. & Peneliti, Tahun, Judul & Tujuan Utama & Metode & Hasil \\
\hline 13 & $\begin{array}{l}\text { Haryono (2014) } \\
\text { Speleogenesis Gua Pindul } \\
\text { dan } \\
\text { Sekitarnya }\end{array}$ & $\begin{array}{l}\text { Mengetahui } \\
\text { pola morfologi } \\
\text { dan } \\
\text { perkembangan } \\
\text { Sistem Karst } \\
\text { Gua Pindul. }\end{array}$ & $\begin{array}{l}\text { Survei lapangan } \\
\text { dan tracing test }\end{array}$ & $\begin{array}{l}\text { Terdapat sistem } \\
\text { perguuaan yang } \\
\text { saling terhubung } \\
\text { pada Gua Asri, } \\
\text { Gua Emas, Gua } \\
\text { Greng, Gua Candi } \\
\text { dan Gua Si Oyot } \\
\text { sebelum } \\
\text { mengimbuh Gua } \\
\text { Pindul. }\end{array}$ \\
\hline 14 & $\begin{array}{l}\text { Agniy (2016), Kajian } \\
\text { Hidrogeologi Karst Sistem } \\
\text { Gua Pindul, Kecamatan } \\
\text { Karangmojo, Kabupaten } \\
\text { Gunungkidul }\end{array}$ & $\begin{array}{l}\text { Mengetahui } \\
\text { batas daerah } \\
\text { tangkapan } \\
\text { permukaan dan } \\
\text { karakteristik } \\
\text { akuifer karst } \\
\text { Sistem Pindul }\end{array}$ & $\begin{array}{l}\text { Observasi } \\
\text { lapangan, } \\
\text { embuatan } \\
\text { flownet, uji } \\
\text { tracer, pumping } \\
\text { test }\end{array}$ & $\begin{array}{l}\text { DTA Sistem } \\
\text { Pindul memiliki } \\
\text { luas } 15,44 \mathrm{~km}^{2} \text {. } \\
\text { Sistem Pindul } \\
\text { memiliki } \\
\text { imbuhan dari } \\
\text { zona conduit } \\
\left(1,74 \mathrm{~km}^{2}\right) \text { dan } \\
\text { diffuse }(13,7 \\
\left.\mathrm{km}^{2}\right) \text {. }\end{array}$ \\
\hline 15 & $\begin{array}{l}\text { Nurkholis (2017), Variasi } \\
\text { Spasial dan Temporal Sifat } \\
\text { Aliran, Respons Debit } \\
\text { Terhadap Hujan, dan } \\
\text { Perilaku Banjir Sistem } \\
\text { Drainase Karst Pindul }\end{array}$ & $\begin{array}{l}\text { Mengetahui } \\
\text { karakteristik } \\
\text { sifat aliran, } \\
\text { hubungan debit- } \\
\text { hujan, dan } \\
\text { karakteristik } \\
\text { banjir }\end{array}$ & $\begin{array}{l}\text { Konstanta resesi, } \\
\text { pemisahan aliran } \\
\text { dasar, time series } \\
\text { analysis, } \\
\text { hidrograf banjir }\end{array}$ & $\begin{array}{l}\text { Gua Pindul } \\
\text { melepaskan } \\
\text { komponen aliran } \\
\text { lebih cepat } \\
\text { dibandingkang } \\
\text { sinking stream } \\
\text { Kedungbuntung } \\
\text { akibat adanya } \\
\text { suplai dari } \\
\text { jaringan conduit } \\
\text { gua-gua yang } \\
\text { saling terhubung. } \\
\text { Debit puncak } \\
\text { paling } \\
\text { dipengaruhi } \\
\text { hujan efektif }\end{array}$ \\
\hline
\end{tabular}

\subsection{Kerangka Pemikiran}

Karst memiliki kondisi hidrologi yang unik yang dicirikan dengan jarangnya aliran permukaan dan terbentuknya jaringan drainase bawah permukaan. Jaringan ini terdiri dari sistem rongga, rekahan, hingga perpipaan yang sering disebut sebagai sungai bawah tanah (SBT). Keunikan bentukan karst diakibatkan oleh material batuan yang mudah larut dan terbentuknya porositas sekunder batuan. Hal tersebut menjadikan akuifer karst tergolong sebagai heterogen atau anistropis. 
Sistem hidrologi karst yang unik menjadikan akuifer karst memiliki empat imbuhan dan tiga sifat aliran. Imbuhan sistem drainase karst tersebut adalah allogenic recharge, internal runoff, diffuse infiltration, dan perch aquifer recharge. Keempat imbuhan tersebut tidak selalu ada pada suatu sistem drainase karst. Sistem Drainase Karst Pindul memiliki keempat imbuhan tersebut.

Sifat aliran yang dimiliki sistem drainase karst adalah diffuse, fissure, dan conduit. Ketiga sifat aliran tersebut identik dengan komponen-komponen hidrograf pada sistem aliran permukaan. Aliran diffuse identik dengan baseflow. Aliran fissure identik dengan interflow, dan aliran conduit identik dengan overlandflow. Oleh karena itu, analisis konstanta resesi pada sistem drainase karst dapat menjelaskan sifat aliran yang mendominasi.

Konsep pemisahan komponen hidrograf dilakukan untuk mendapatkan aliran dasar. Komponen hidrograf yang dipisahkan terdiri dari overlandflow dan baseflow. Perbandingan nilai baseflow dengan total debit aliran menghasilkan prosentase aliran dasar (PAD). Nilai PAD suatu sistem drainase karst juga dapat menjelaskan komponen aliran yang mendominasi.

Tingkat karstifikasi akan memengaruhi respons sistem drainase karst terhadap curah hujan. Sistem drainase karst dengan dominasi retakan conduit akan langsung mengubah hujan menjadi debit aliran sungai bawah tanah. Sementara itu, karst dengan dominasi retakan diffuse akan menyimpan hujan pada lapisan epikarst dan melepaskannya perlahan-lahan.

Hidrograf banjir mempunyai bentuk seperti lonceng yang terdiri dari beberapa parameter utama, yaitu $\mathrm{T}_{\mathrm{p}}$ (time to peak), $\mathrm{Q}_{\mathrm{p}}$ (debit puncak), dan $\mathrm{T}_{\mathrm{b}}$ (time to baseflow). Bentuk hidrograf banjir dari suatu daerah tangkapan air mencerminkan responnya terhadap karakteristik hujan (tebal, puncak, dan durasi). Selain itu, perhitungan hujan efektif (hujan yang menjadi overlandflow) juga dapat dilakukan. Oleh karena itu, hidrograf banjir dan karakteristik hujan dapat menjelaskan perilaku banjir di Sistem Drainase Karst Pindul. Gambar 1.9 menjelaskan alur pemikiran pada penelitian ini. 


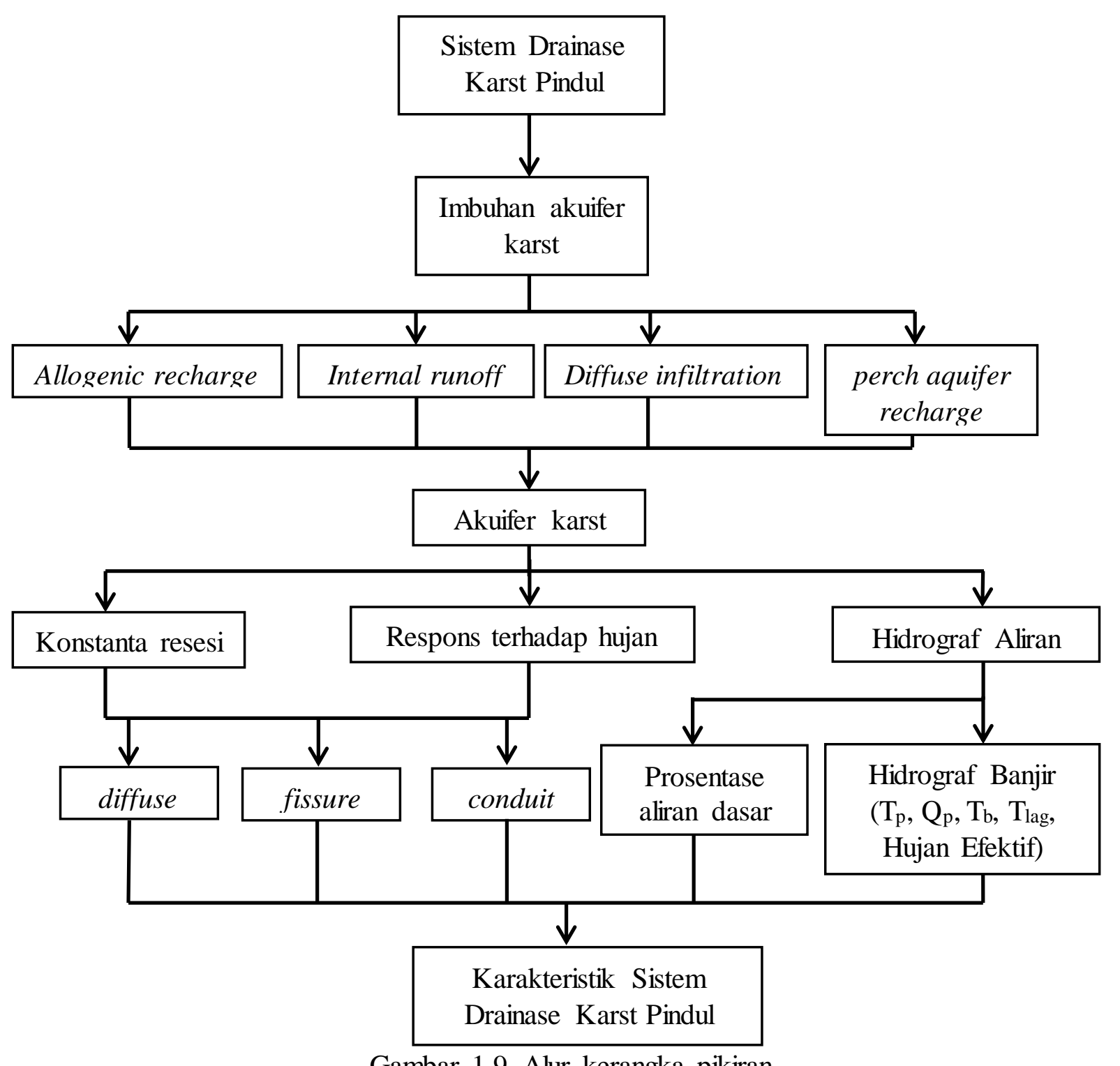

Gambar 1.9. Alur kerangka pikiran 


\section{BAB II \\ METODE PENELITIAN}

\subsection{Alat dan Bahan Penelitian}

\subsubsection{Alat Penelitian}

Alat yang digunakan untuk penelitian ini adalah sebagai berikut:

1. Automatic Water Level Logger (3 buah), untuk mengukur fluktuasi tinggi muka air (TMA) di Gua Pindul, Sinking Stream Kedungbuntung, dan sebagai logger kalibrasi.

2. Penakar hujan otomatis (1 buah), untuk mencatat tebal hujan

3. Piskal (4 buah), untuk mengukur fluktuasi TMA pada lokasi pengukuran debit di Gua Pindul (2 buah) dan Sinking Stream Kedungbuntung (2 buah).

4. Meteran (2 buah), untuk mengukur panjang, lebar, serta kedalaman saluran di Gua Pindul dan Sinking Stream Kedungbuntung.

5. Jallon untuk membagi segmen dalam pengukuran debit aliran.

6. Laptop untuk mengolah dan men-download data hujan serta TMA dari logger.

7. Global Positioning System (GPS) untuk menentukan lokasi absolut di lapangan.

8. Software BFI+ untuk melakukan pemisahan aliran dasar.

9. Software Microsoft Office 2017 untuk menulis laporan.

10. Software Microsoft Excel 2017 untuk mengolah data angka.

11. Software XLSTAT 2017 untuk analisis statistik hubungan debit-hujan.

12. Software ArcGIS 10.1 untuk mngolah data spasial.

Lokasi pemasangan logger muka air dan hujan dapat dilihat pada Gambar 3.9.

\subsubsection{Bahan Penelitian}

Bahan yang digunakan untuk penelitian ini adalah sebagai berikut:

1. Peta Rupa Bumi Indonesa (RBI) skala 1:25.000 lembar Wonosari dan Karangmojo tahun 1998 untuk orientasi dan mengenali wilayah penelitian.

2. Peta Geologi Lembar Yogyakarta 1408-2 \& 1407-5 Skala 1:100.000 tahun 1995 untuk mengidentifikasi jenis batuan penyusun akuifer di lokasi kajian. 
3. Citra Google Eye lokasi penelitian tahun 2015 untuk membantu melakukan digitasi penggunaan lahan.

4. Shapefile atau data digital batas administrasi, penggunaan lahan, jaringan sungai, persebaran gua dan mataair untuk pembuatan peta digital dan mengidentifikasi lokasi kajian

\subsection{Data Penelitian}

Data yang dikumpulkan dalam penelitian terdiri dari data primer dan sekunder berdasarkan cara perolehannya. Data primer merupakan data yang didapatkan langsung dari lapangan. Data primer yang dikumpulkan adalah sebagai berikut:

1. Data tinggi muka air (TMA) di kedua lokasi penelitian untuk pembuatan rating curve.

2. Data debit aliran pengukuran lapangan di kedua lokasi penelitian untuk pembuatan rating curve.

3. Data hujan wilayah sekitar Sistem Karst Gua Pindul untuk time series analysis dan analisis perilaku banjir.

Data sekunder merupakan data yang diperoleh dari hasil pengolahan pihak kedua. Data tersebut diantaranya adalah:

1. Data jenis batuan penyusun akuifer untuk membantu analisis karakteristik sistem drainase karst.

2. Data sistem perguaan dan mataair untuk membantu analisis karakteristik sistem drainase karst.

\subsection{Cara Penelitian}

\subsubsection{Teknik Pengumpulan Data}

\section{a. Pencatatan Data Tinggi Muka Air (TMA)}

TMA dicatat secara otomatis menggunakan alat automatic water level logger yang biasa disebut logger muka air (Gambar 2.1). Logger muka air yang digunakan adalah Hobo U-20-01 yang mampu mencatat hingga kedalaman 12 meter pada air tawar. Alat ini dipasang pada kedua lokasi pengukuran. Prinsip kerja logger adalah mencatat TMA berdasarkan perbandingan tekanan udara dengan 
tekanan di dalam air. Pencatatan data TMA diatur setiap 15 menit sekali dengan pertimbangan mampu mencatat fluktuasi yang terjadi.

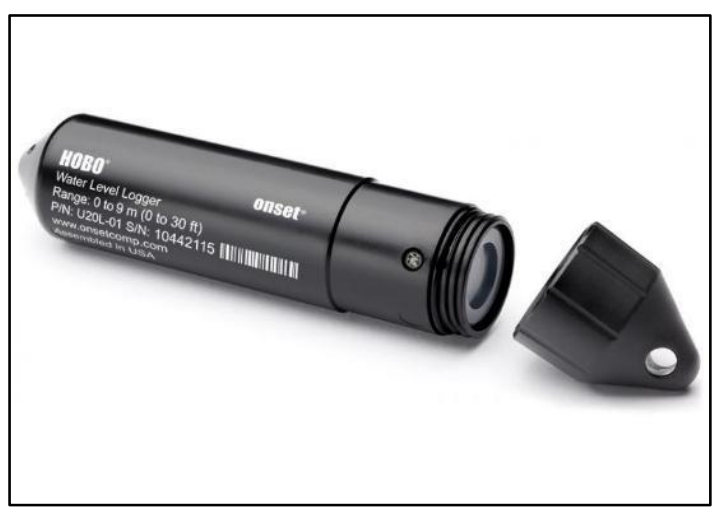

Gambar 2.1. Logger muka air Hobo U-20-01 (sumber:

http://www.onsetcomp.com/products/data-loggers/u201-01\#)

\section{b. Pencatatan Data Tebal Hujan}

Tebal hujan dicatat menggunakan satu penakar hujan otomatis. Agniy (2016) melakukan penelitian yang menunjukkan bahwa luas DTA Sistem Karst Pindul adalah $15,44 \mathrm{~km}^{2}$. Berdasarkan data tersebut, alat penakar hujan dipasang di tangah sistem dengan pertimbangan mewakili curah hujan yang terjadi (Gambar 3.9). Alat tersebut adalah Hobo RG-03 (Gambar 2.2). Alat penakar tersebut mengukur tebal hujan sewaktu-waktu apabila ada air yang mengisinya. Air hujan yang masuk akan mengetuk alat pencatat otomatis. Satu kali ketukan setara dengan $0,2 \mathrm{~mm}$.

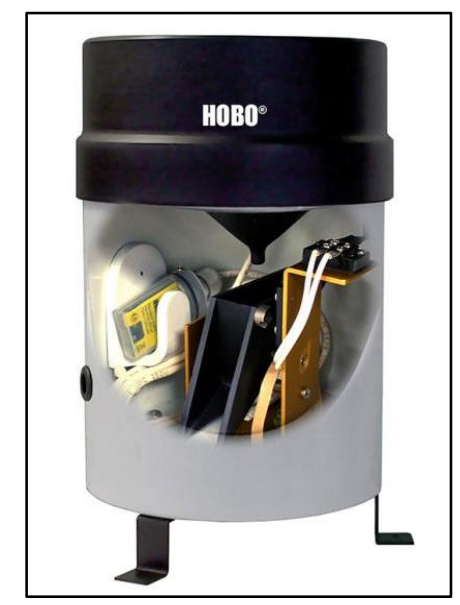

Gambar 2.2. Logger hujan Hobo RG-03

(sumber: http://www.onsetcomp.com/products/data-loggers/rg3) 


\section{c. Pengukuran Debit Aliran}

Debit merupakan volume air yang mengalir pada penampang sungai persatuan waktu (Soewarno, 1991). Menurut Linsley, dkk (1975) metode pengukuran debit yang paling akurat adalalah velocity method. Meskipun demikian, pengukuran debit di penelitian ini dilakukan menggunakan slope method. Hal ini dikarenakan kecepatan arus saat debit normal pada lokasi penelitian terlalu kecil sehingga alat ukur kecepatan aliran tidak berfungsi dengan baik.

Slope method yang paling umum digunakan adalah koefisien manning (Chow, 1959; Linsley, dkk, 1975; Seyhan, 1977; Soewarno, 1991). Metode ini memodelkan kecepatan arus dengan persamaan matematika berdasarkan kemiringan muka air. Sementara itu, luas penampang tetap diukur di lapangan. Persamaan slope method dengan koefisien manning dijelaskan pada persamaan 1 .

$$
Q=A\left(\frac{R^{2} / 3 S^{1 / 2}}{n}\right)
$$

dimana Q merupakan debit aliran $\left(\mathrm{m}^{3} / \mathrm{s}\right)$, A merupakan luas penampang sungai $\left(\mathrm{m}^{2}\right)$, S merupakan kemiringan sungai $(\mathrm{m}), \mathrm{n}$ merupakan koefisien manning, dan $\mathrm{R}$ merupakan radius hydraulic sungai (m) yang dapat dihitung dengan persamaan berkut:

$$
R=\frac{A}{P}
$$

dimana P merupakan perimeter basah (m)

Luas penampang sungai (A) didapatkan dengan mengukur kedalaman dan lebar setiap segmen (Seyhan, 1977). Semakin kecil segmen maka pengukuran semakin akurat (Gambar 2.3). Sementara itu, Pengukuran kemiringan sungai dijelaskan oleh Gambar 2.4. Persamaan kemiringan sungai adalah sebagai berikut:

$$
S=\frac{(b-a)}{L}
$$

dimana a dan b merupakan tinggi muka air sungai, dan L merupakan panjang sungai pada pengukuran kedua muka air.

Koefisien manning (n) didapatkan dari penilaian enam parameter (Tabel 2.1). Parameter tersebut didasarkan atas percobaan pada suatu DAS (daerah aliran sungai) dan telah dilakukan validasi sebanyak 160 percobaan (Chow, 1959). 
Tabel 2.1. Penilaian koefisien manning (Chow, 1959)

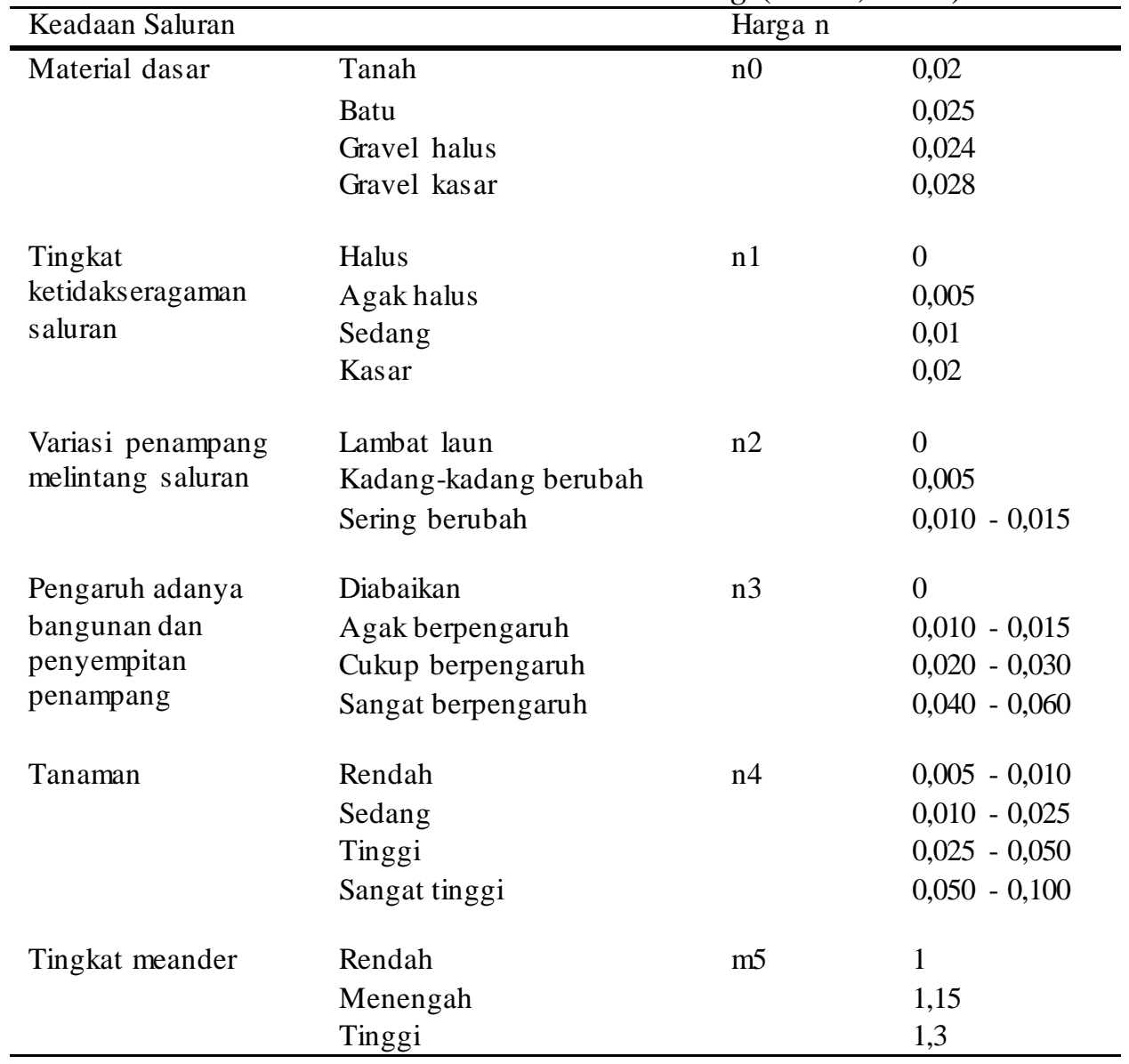

Keterangan: $n=(n 0+n 1+n 2+n 4) m 5$

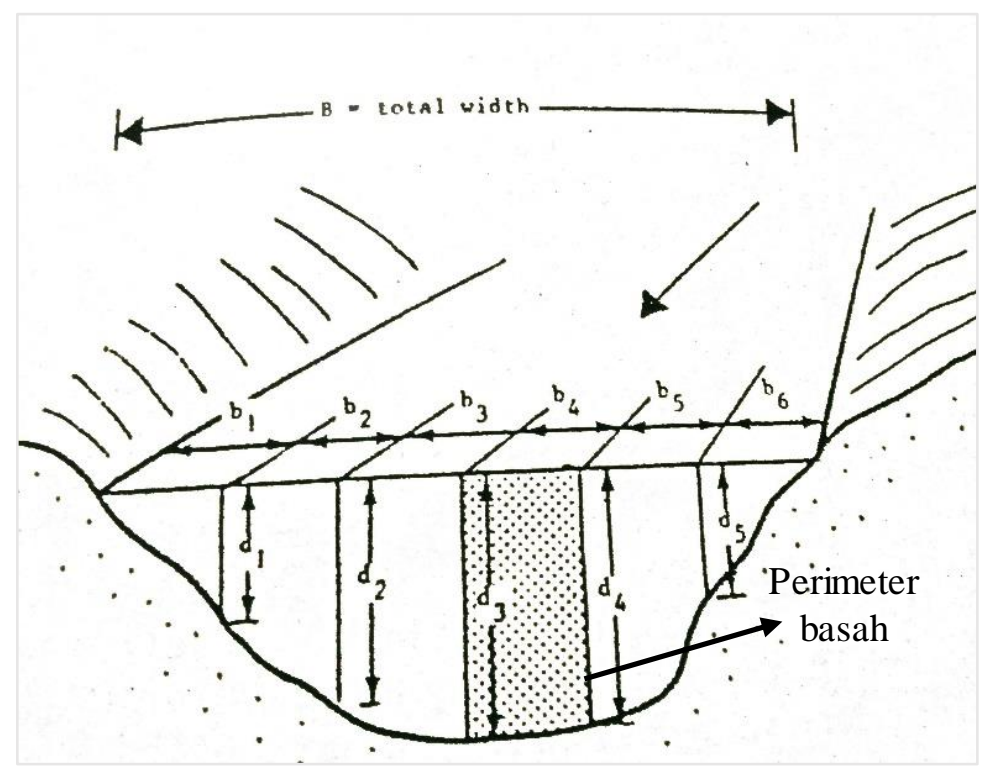

Gambar 2.3. Pengukuan luas penampang sungai (Seyhan, 1977) 


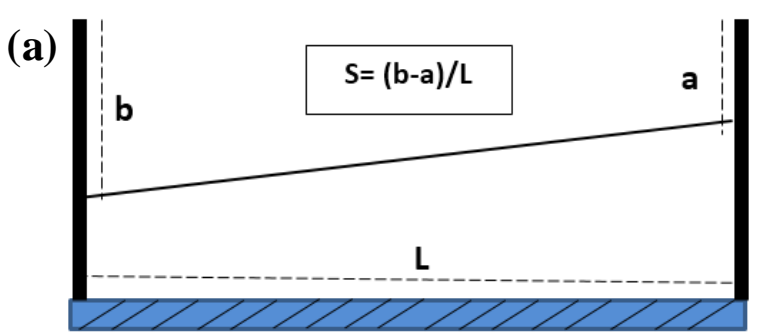

Gambar 2.4. (a) Ilustrasi perhitungan kemiringan sungai

(b)

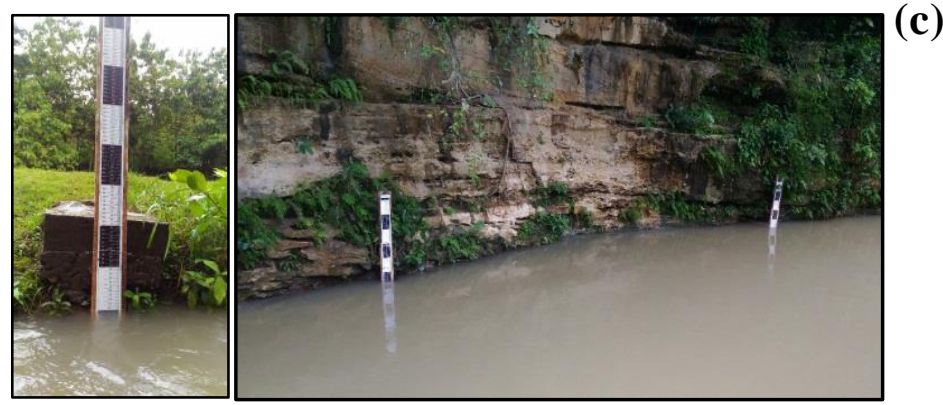

Gambar 2.4. (b) dan (c). Pemasangan piskal di lokasi kajian untuk menghitung kemiringan sungai

\subsubsection{Teknik Pengolahan Data}

\section{a. Pengolahan Data untuk Karakterisasi Pelepasan Komponen Aliran dan}

Prosentase Aliran Dasar

\section{Pembuatan Rating Curve dan Hidrograf Aliran}

Hubungan antara debit aliran dengan TMA akan membentuk suatu kurva yang disebut rating curve (Linsley, dkk, 1975; Soewarno, 1991). Kurva tersebut dibuat berdasarkan pengukuran debit dan TMA yang telah dijelaskan diatas. Contoh rating curve dapat dilihat pada Gambar 2.5. Schulz (1976) menyatakan bahwa rating curve akan menghasilkan koefisien yang dapat digunakan untuk membuat hidrograf aliran. Hidrograf tersebut dapat dibuat berdasarkan pencatatan TMA secara otomatis yang dilakukan di penelitian ini. Persamaan rating curve yang menghasilkan debit aliran berdasarkan konstanta adalah sebagai berikut:

$$
Q=a\left(H-H_{0}\right)^{b}
$$

dimana Q merupakan debit aliran, a dan b merupakan konstanta hasil regresi, $\mathrm{H}$ merupakan TMA pencatatan logger, dan $\mathrm{H}_{0}$ merupakan TMA ketika debit aliran nol. 


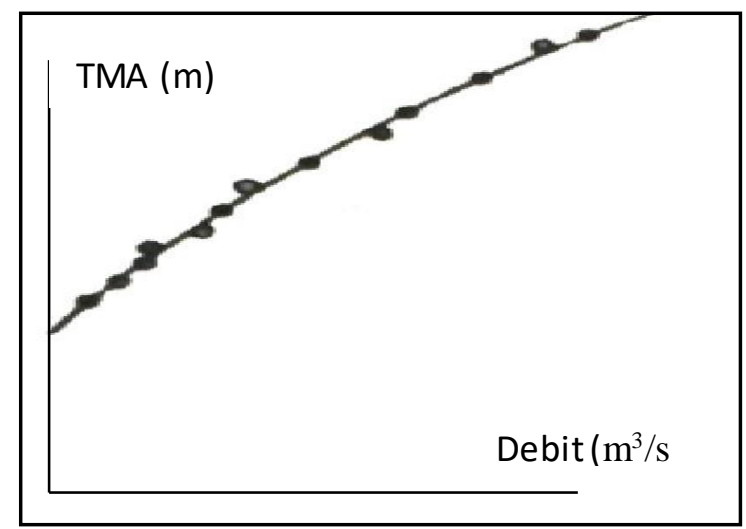

Gambar 2.5. Rating curve (Soewarno, 1991)

\section{Pemilihan Kejadian Banjir dan Perhitungan Konstanta Resesi}

Konstanta resesi dihitung pada hidrograf yang memiliki kejadian banjir. Setelah terjadinya puncak banjir, hidrograf akan mengalami resesi yang dapat dihitung konstantanya. Persamaan kurva resesi menurut Barnes (1940, dalam Schulz, 1976) adalah sebagai berikut:

$$
Q_{t}=Q_{0} e^{-k t}
$$

dimana $\mathrm{Q}_{\mathrm{t}}$ merupakan debit aliran pada waktu ke-t, $\mathrm{Q}_{0}$ merupakan debit aliran pada waktu (t-n), $\mathrm{e}^{-\mathrm{k}}$ merupakan konstanta resesi yang dapat disimbolkan dengan $\mathrm{K}_{\mathrm{r}}$, dan t merupakan waktu.

Hasil ploting dalam skala semi-log menunjukkan bahwa persamaan tersebut linier sehingga dapat diubah menjadi seperti berikut:

$$
\begin{gathered}
\ln Q_{t}=\frac{-1}{\left(t-t_{0}\right)} \ln \left(\frac{Q_{t}}{Q_{0}}\right) \\
K_{r}=\frac{-1}{\left(t-t_{0}\right)} \ln \left(\frac{Q_{t}}{Q_{0}}\right) \ldots
\end{gathered}
$$

Schulz (1976) mengungkapkan bahwa selama kejadian resesi terdapat tiga komponen utama, yaitu streamflow (Krs), interflow (Kri), dan baseflow (Kb). Persamaan dari ketiga resesi tersebut adalah sebagai berikut:

$$
K_{r}=K_{r s}+K_{r i}+K_{b}
$$

Adji, dkk, (2006), Adji (2009), Bahtiar dan Adji (2016) menggunakan konsep konstanta resesi untuk mengkarakterisasi sifat aliran karst yang dicerminkan oleh komponen pelepasannya. Konsep tersebut mengidentikkan komponen sreamflow dengan conduit, komponen interflow dengan fissure, dan 
komponen baseflow dengan diffuse. Schulz(1976) mengkategorikan nilai konstanta setiap komponen tersebut seperti pada Tabel 2.2.

Tabel 2.2. Nilai konstanta resesi (Schulz, 1976)

\begin{tabular}{ll}
\hline Komponen aliran & Nilai konstanta resesi \\
\hline Overlandflow/ conduit & $0,05-0,5$ \\
Interflow/fissure & $0,5-0,85$ \\
Baseflow/diffuse & $0,80-0,98$ \\
\hline
\end{tabular}

Menurut Schulz (1976), tidak semua hidrograf banjir memiliki ketiga komponen resesi. Penelitian ini akan menggunakan konstanta resesi untuk mengkarakterisasi sistem drainase karst sehingga hidrograf banjir dipilih pada bentuk yang memiliki satu kali kejadian hujan dan memiliki waktu resesi cukup panjang. Contoh hidrograf banjir yang dapat dihitung konstanta resesinya dapat dilihat pada Gambar 2.6.

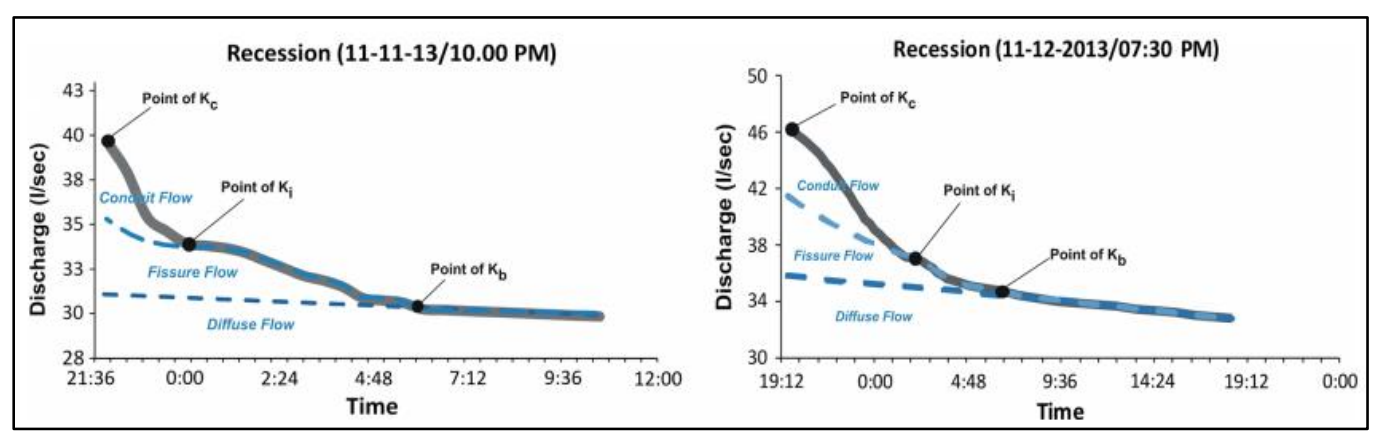

Gambar 2.6. Contoh resesi hidrograf banjir terpilih (Adji dan Bahtiar, 2016)

\section{Pemisahan Aliran Dasar}

Pemisahan aliran dasar pada penelitian ini menggunakan metode recursive digital filter yang dikembangkan oleh Lyne dan Hollick (1979). Metode ini menggunakan prinsip yang biasa digunakan dalam analisis dan pemrosesan sinyal. Quickflow mempunyai sifat frekuensi tinggi, sedangkan baseflow mempunyai sifat frekuensi rendah (Nathan dan McMahon, 1990). Persamaan recursive digital filter dari Lyne dan Hollick (1979) adalah sebagai berikut:

$$
\begin{aligned}
f_{k} & =\alpha f_{k-1}+\frac{(1+\alpha)}{2}\left(y_{k}-y_{k-1}\right) \\
b_{k} & =y_{k}-f_{k} \ldots \ldots \ldots \ldots \ldots \ldots \ldots \ldots \ldots \ldots \ldots \ldots \ldots \ldots \ldots \ldots \ldots
\end{aligned}
$$


dimana $\mathrm{f}_{\mathrm{k}}$ merupakan quickflow pada waktu $\mathrm{k}$, yk merupakan debit aliran pada waktu $\mathrm{k}, \alpha$ merupakan konstanta resesi aliran dasar, dan $b_{\mathrm{k}}$ merupakan baseflow pada waktu $\mathrm{k}$.

Pemisahan aliran dasar dilakukan dengan modul BFI+ dari software hydroOffice 2010. Modul tersebut dikembangkan oleh Milos Gregor. BFI+ memiliki sebelas metode pemisahan aliran dasar (Gregor, 2010). Penggunaan modul ini membutuhkan input debit aliran dan waktu secara time series.

\section{b. Pengolahan Data untuk Karakterisasi Banjir}

\section{Perhitungan Hujan Efektif}

Hujan efektif adalah hujan yang tidak terinfiltrasi atau menggenang di permukaan (Chow, dkk, 1988). Dalam kata lain, hujan efektif adalah hujan yang menjadi aliran permukaan. Hujan efektif umumnya digunakan untuk membuat hidrograf satuan, yaitu hidrograf yang dihasilkan dari hujan setebal $1 \mathrm{~mm}$ yang diasumsikan jatuh merata pada daerah tangkapan air (Linsley, dkk, 1975; Seyhan, 1977).

Penelitian ini menggunakan konsep hujan efektif untuk menganalis is seberapa besar hujan yang menjadi aliran permukaan dan bagaimana hubunga nnya dengan debit puncak pada Sistem Drainase Karst Pindul. Menurut Chow, dkk (1988), hujan efektif dapat dihitung dengan langkah sebagai berikut (Gambar 2.7):

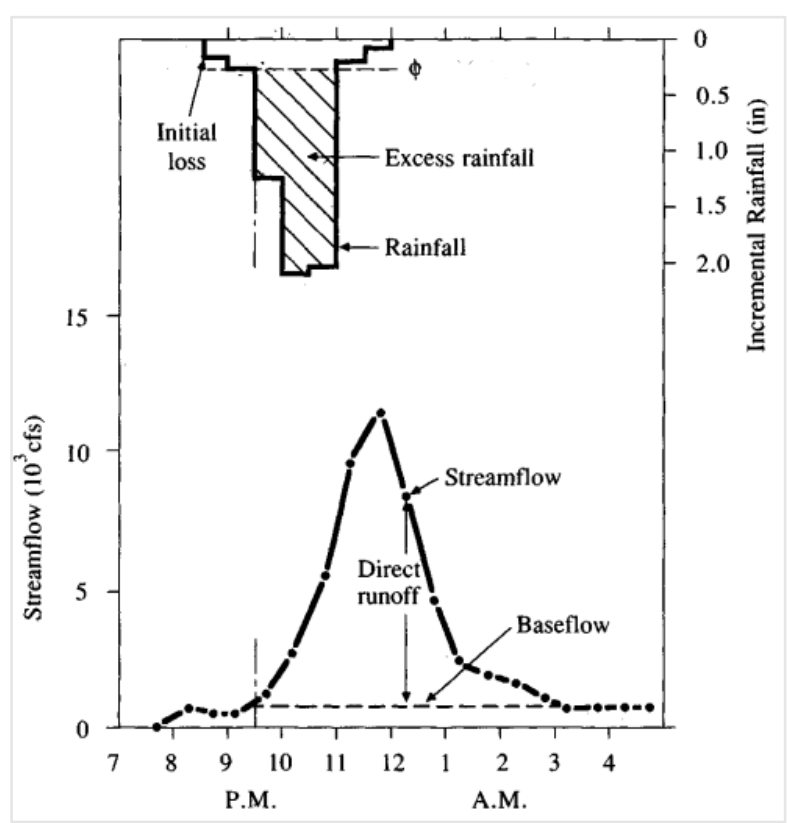

Gambar 2.7. Grafik hasil perhitungan hujan efektif (Chow, dkk, 1988) 
- Langkah pertama adalah menghitung aliran dasar. Penelitian ini menghitung aliran dasar secara kontinu menggunakan digital filtering seperti dijelaskan pada Subbab 2.3.2.a.3.

- Langkah kedua adalah menghitung nilai total aliran permukaan dengan cara mengurangi debit aliran dengan aliran dasar kemudian dijumlahkan seluruhnya.

- Langkah ketiga adalah menghitung volume aliran permukaan dengan rumus sebagai berikut:

$V\left(m^{3}\right)=$ total run off $\left(\frac{m^{3}}{\text { detik }}\right) x$ waktu pengukuran $(j a m) x \frac{3600 \text { detik }}{1 \text { jam }}$

- Langkah keempat adalah menghitung tebal aliran permukaan $\left(\mathrm{r}_{\mathrm{d}}\right)$ dengan rumus berikut:

$$
r_{d}(m m)=\frac{V\left(m^{3}\right)}{\text { Luas daerah tangkapan }\left(m^{2}\right)} \times 1000
$$

- Langkah kelima adalah menghitung initial abstraction $(\phi)$, yaitu hujan yang mengalami infiltasi, penggenangan, atau evapotranspirasi, dengan rumus berikut:

$$
\begin{aligned}
& r_{d}(m m)=\sum_{m=1}^{M}\left(R_{m}-\phi \Delta t 1 j a m\right) \\
& \phi\left(\frac{m m}{j a m}\right)=\frac{\left(R_{1}+R_{2}+. . R_{M}\right)-r_{d}}{(1+2+. . M) \Delta t 1 j a m} \ldots \ldots \ldots \ldots \ldots \ldots \ldots \ldots
\end{aligned}
$$

- Langkah keenam dilakukan dengan mengurangi hujan maksimum $\left(\mathrm{R}_{\mathrm{m}}\right)$ yang digunakan pada persamaan 30 dengan nilai $\phi$. Hujan efektif adalah jumlah dari nilai tersebut.

\section{Perhitungan Parameter Hidrograf Banjir}

Hidrograf banjir mempunyai bentuk seperti lonceng yang terdiri dari beberapa komponen utama, yaitu $\mathrm{T}_{\mathrm{p}}$ (time to peak), $\mathrm{Q}_{\mathrm{p}}$ (debit puncak), dan $\mathrm{T}_{\mathrm{b}}$ (time to baseflow) (Gambar 2.8). Menurut Adji dan Cahyadi (2016), parameter yang disebutkan diatas dapat digunakan untuk mengkarakterisasi sistem drainase karst karena mencerminkan kondisi daerah tangkapan, simpanan akuifer, cara pelepasan komponen aliran, dan bagaimana hubungan curah hujan dengan debit aliran. 


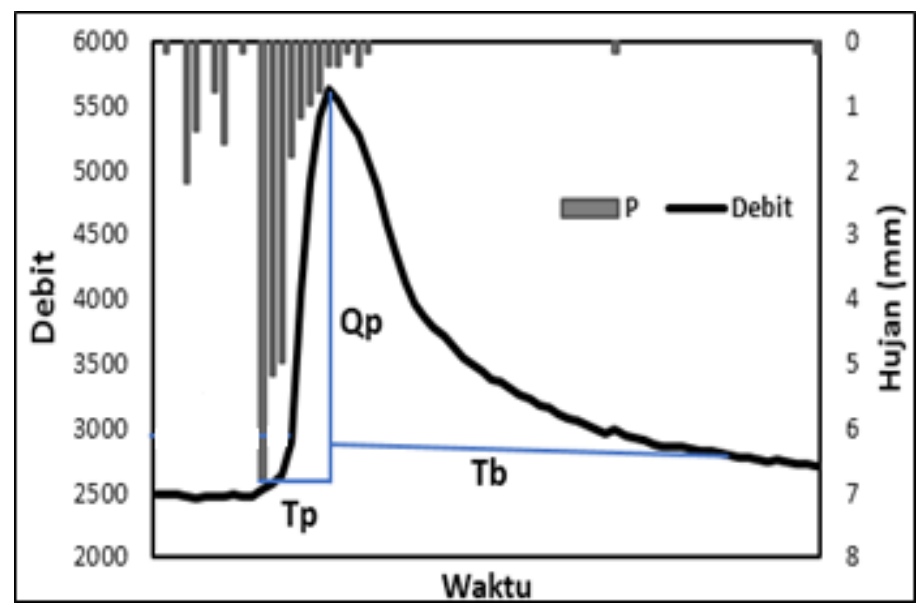

Gambar 2.8. Ilustrasi parameter hidrograf banjir

Parameter hidrograf tersebut dapat dihitung menggunkaan definisi dari Linsley, dkk (1975) dan Seyhan (1977), yaitu: (1) $T_{\mathrm{p}}$ merupakan panjang waktu dari puncak hujan hingga terjadinya debit puncak, (2) $Q_{p}$ merupakan nilai debit puncak banjir, (3) $\mathrm{T}_{\mathrm{b}}$ merupakan panjang waktu setelah terjadinya $\mathrm{Q}_{\mathrm{p}}$ hingga kembali menjadi aliran dasar.

\section{c. Pengolahan Data untuk Karakterisasi Respons Debit Terhadap Hujan}

Karakterisasi respons debit terhadap hujan dilakukan menggunakan time series analysis. Konsep dari metode ini adalah menganggap sistem drainase karst sebagai black box yang tidak diketahui kinerjanya (Ford \& Williams, 1989). Analisis dilakukan melalui hubungan input (curah hujan) dengan output (debit aliran atau muka airtanah) yang diolah secara statistik (Mangin, 1984; Kovacs dan Sauter, 2007) (Gambar 2.9).

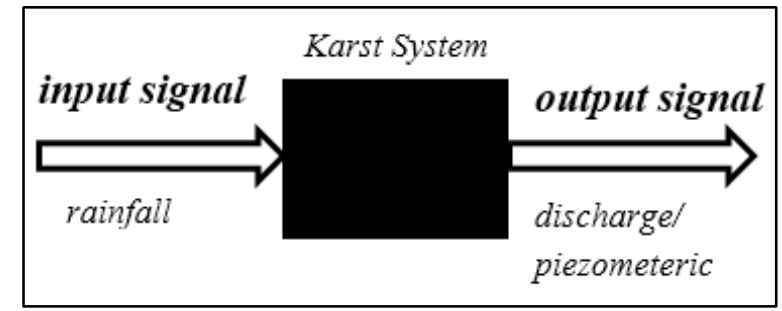

Gambar 2.9. Ilustrasi time series analysis sebagai model black box

Time series analysis menggunakan perhitungan statistik berupa univariate (auto-correlation) dan bivariate (cross-correlation) (Kovacs dan Sauter, 2007). Kedua metode menganalisis data berdasarkan waktu dan dapat diubah bentuk menjadi analisis frekuensi. Auto-correllation dapat diubah menjadi spectral 
density. Cross-correlation dapat diubah menjadi cross-amplitude, phase function, coherency function, dan gain function. Zang, dkk, (2013) mengklasifikasikan metode time series analysis untuk karakterisasi sistem drainase karst (Tabel 2.3). Panagopoulus dan Lambarakis (2006) menjelaskan metode-metode tersebut dalam kaitannya dengan karakterisasi sistem drainase karst, yaitu:

Tabel 2.3. Klasifikasi time series analysis untuk karakterisasi sistem drainase karst (Zang, dkk, 2013 dengan modifikasi)

\begin{tabular}{|c|c|c|c|c|}
\hline \multicolumn{2}{|c|}{ Respons sistem drainase karst } & \multirow{2}{*}{$\begin{array}{l}\text { Definisi } \\
\text { Nilai rerata respons } \\
\text { cepat hidrograf } \\
\text { terhadap hujan. Tlag } \\
\text { dihitung pada rising } \\
\text { limb hidrograf }\end{array}$} & \multirow[b]{2}{*}{$\begin{array}{l}\text { Metode } \\
\text { Cross- } \\
\text { correlation } \\
\text { Phase } \\
\text { functions } \\
\text { Cross- } \\
\text { amplitude }\end{array}$} & \multirow[b]{2}{*}{$\begin{array}{l}\text { Indikator } \\
\text { Waktu dari puncak } \\
\text { grafik } \\
\text { Time delay }(\mathrm{d})= \\
\theta x y(\mathrm{f})) / 2 \pi \mathrm{f} \\
\text { Nilai ketika mendekati } \\
\text { nol }\end{array}$} \\
\hline $\begin{array}{l}\text { Aliran } \\
\text { conduit }\end{array}$ & $\begin{array}{l}\text { Waktu tunda } \\
\text { aliran conduit }\end{array}$ & & & \\
\hline & $\begin{array}{l}\text { Durasi minimum } \\
\text { aliran conduit }\end{array}$ & $\begin{array}{l}\text { Durasi minimum } \\
\text { pelepasan aliran } \\
\text { conduit yang dihitung } \\
\text { dari resesi } \mathrm{K}_{\mathrm{c}}\end{array}$ & Gain functions & $\operatorname{Gxy}(f)<0,4$ \\
\hline \multirow[t]{2}{*}{$\begin{array}{l}\text { Aliran } \\
\text { diffuse }\end{array}$} & $\begin{array}{l}\text { Rerata durasi } \\
\text { aliran diffuse }\end{array}$ & $\begin{array}{l}\text { Rerata durasi yang } \\
\text { dihitung menggunakan } \\
\mathrm{Kb}\end{array}$ & $\begin{array}{l}\text { Auto- } \\
\text { correlation } \\
\text { Spectral } \\
\text { density } \\
\text { functions }\end{array}$ & $\begin{array}{l}\text { Memory effect }(c)= \\
2 /\left(\mathrm{n}^{\wedge} 0,5\right) \\
\text { Regulation time }(\text { treg })= \\
\mathrm{s}(\mathrm{f}=0) / 2\end{array}$ \\
\hline & $\begin{array}{l}\text { Durasi } \\
\text { maksimum } \\
\text { aliran diffuse }\end{array}$ & $\begin{array}{l}\text { Durasi maksimum } \\
\text { pelepasan aliran diffuse } \\
\text { yang dihitung dari } \\
\text { resesi } \mathrm{Kb}\end{array}$ & Gain functions & $\operatorname{Gxy}(f)>1$ \\
\hline \multirow[t]{2}{*}{$\begin{array}{l}\text { Aliran } \\
\text { fissure }\end{array}$} & $\begin{array}{l}\text { Rerata durasi } \\
\text { aliran fissure }\end{array}$ & $\begin{array}{l}\text { Rerata durasi yang } \\
\text { dihitung menggunakan } \\
\mathrm{K}_{\mathrm{i}}\end{array}$ & $\begin{array}{l}\text { Auto- } \\
\text { correlation } \\
\text { Cross- } \\
\text { correlation }\end{array}$ & $\begin{array}{l}\text { Permulaan penurunan } \\
\text { tajam grafik } \\
\text { Permulaan penurunan } \\
\text { tajam grafik }\end{array}$ \\
\hline & $\begin{array}{l}\text { Durasi aliran } \\
\text { fissure }\end{array}$ & $\begin{array}{l}\text { Durasi yang dihitung } \\
\text { pada selang antara } \mathrm{K}_{\mathrm{c}} \\
\text { dengan } \mathrm{K}_{\mathrm{b}}\end{array}$ & Gain functions & $0,4<\operatorname{gxy}(\mathrm{f})<1$ \\
\hline
\end{tabular}

\section{Auto-Correlation}

Auto-correlation disebut sebagai univariate karena hanya menggunakam satu signal (debit aliran atau TMA) dalam analis isnya. Persamaan metode ini adalah sebagai berikut: 


$$
\begin{aligned}
& r(k)=\frac{C(k)}{C(0)} \\
& C(k)=\frac{1}{n} \sum_{t=1}^{n-k}\left(x_{t}-x \overline{)}\left(x_{t+k}-x \overline{)}\right.\right. \\
& C(0)=\frac{1}{n} \sum_{t=1}^{n}\left(x_{t}-\bar{x}\right)^{2}
\end{aligned}
$$

$\mathrm{C}(\mathrm{k})$ adalah correlogram yang menunjukkan memory effect, yaitu kemampuan sistem dalam menyimpan input signal (curah hujan). Karst yang telah berkembang akan menyimpan input signal dalam waktu yang lebih lama dibandingkan karst yang belum berkembang. Bentuk correlogram diidentikkan dengan grafik resesi hidrograf banjir. Oleh karena itu, grafik $\mathrm{C}(\mathrm{k})$ pada nilai tertentu menunjukkan durasi pelepasan komponen baseflow (durasi penyimpanan input signal) (Gambar 2.10). Nilai tertentu tersebut dihitung menggunakan persamaan berikut:

$$
C(k)=\frac{2}{\sqrt{\text { banyakdata }}}
$$

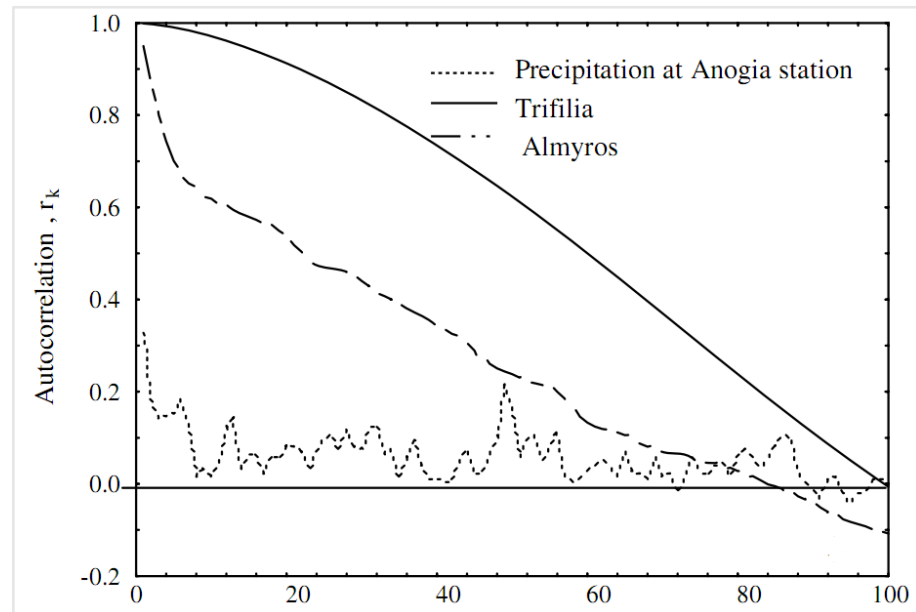

Gambar 2.10. Contoh auto-correlation di dua sistem karst berbeda, Trifilia (dominasi baseflow) dan Almyros (dominasi quickflow)

(Panagopoulus dan Lambarakis, 2006)

\section{Spectral Density}

Perhitungan auto-correlation dapat diubah menjadi bentuk frekuensi yang menghasilkan nilai spectral density. Persamaan spectral density adalah sebagai berikut:

$$
S(f)=2\left[1+2 \sum_{k=1}^{m} D(k) r(k) \cos (2 \pi f k)\right]
$$




$$
D(k)=\frac{1+\cos \pi \frac{k}{m}}{2}
$$

Spectral density menunjukkan distribusi data pada berbagai frekuensi, dimana puncakpuncak grafik meggambarkan siklus atau pola banjir dari suatu sistem karst (Gambar 2.11). Larocque, dkk (1998) dan Zang, dkk (2013) menerangkan bahwa Treg (time regulation) merupakan durasi penyimpanan input signal oleh sistem yang dapat diukur melalui grafik spectral density. Konsep ini menyerupai memory effect pada autocorrelation. Persamaan $\mathrm{T}_{\text {reg }}$ adalah sebagai berikut:

$$
\operatorname{Treg}=\frac{S(f=0)}{2}
$$

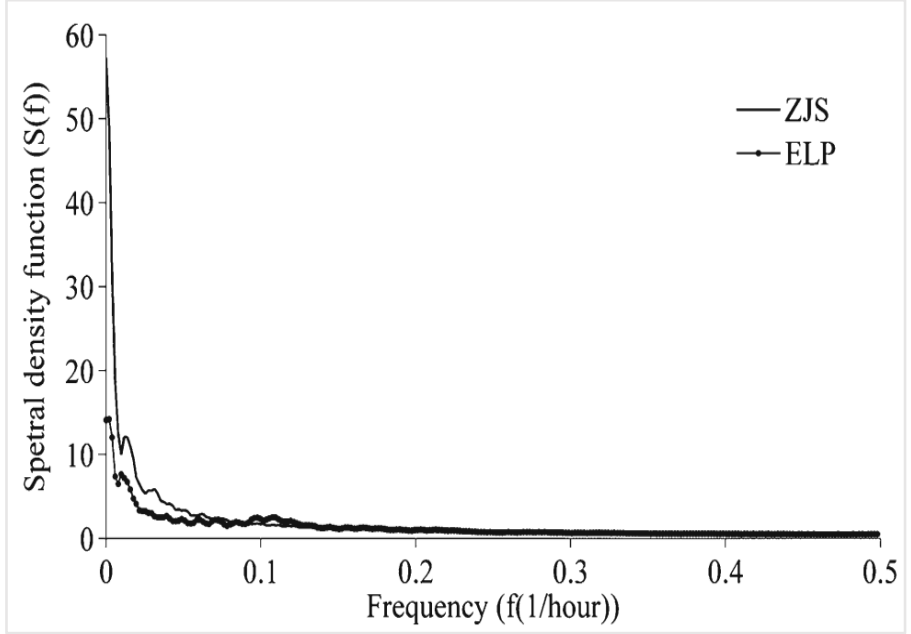

Gambar 2.11. Contoh grafik spectral density, ZJS melepaskan aliran diffuse lebih lambat dibandingkan ELP (Zang, dkk, 2013)

\section{Cross-Correlation}

Cross-correlation merupakan hubungan antata input signal (curah hujan) dengan output signal (debit aliran) (Gambar 2.12) sehingga disebut juga hubungan bivariate. Persamaan dari hubungan ini adalah sebagai berikut:

$$
\begin{aligned}
& r_{x y}(k)=\frac{C_{x y}(k)}{\sqrt{C_{x(0)}^{2} C_{y(0)}^{2}}} \\
& C_{x y}(k)=\frac{1}{n} \sum_{t=1}^{n-k}\left(x_{t}-x \overline{)}\left(y_{t+k}-y \overline{)}\right.\right. \\
& C_{x}(0)=\frac{1}{n} \sum_{t=1}^{n}\left(x_{t}-\bar{x}\right)^{2}
\end{aligned}
$$




$$
C_{y}(0)=\frac{1}{n} \sum_{t=1}^{n}\left(y_{t}-\bar{y}\right)^{2}
$$

$\mathrm{C}_{\mathrm{xy}}(\mathrm{k})$ merupakan cross-correlogram, dimana nilai $\mathrm{T}_{\mathrm{lag}}$ (waktu tunda) adalah rentang antara nilai $\mathrm{T}_{\text {lag }}($ sumbu $\mathrm{x}$ ) ketika nol hingga puncak cross-correlogram. Nilai $\mathrm{C}_{\mathrm{xy}}(\mathrm{k})$ menunjukkan seberapa cepat hujan akan muncul sebagai debit aliran di titik pengukuran. Oleh karena itu, cross-correlgram diidentikkan dengan hidrograf banjir yang memiliki rising limb, debit puncak, dan resesi. $T_{\text {lag }}$ pada metode ini menggambarkan respons sistem karst terhadap aliran conduit. Karst yang telah berkembang akan mempunyai $\mathrm{T}_{\text {lag }}$ yang cepat (Gambar 2.12).

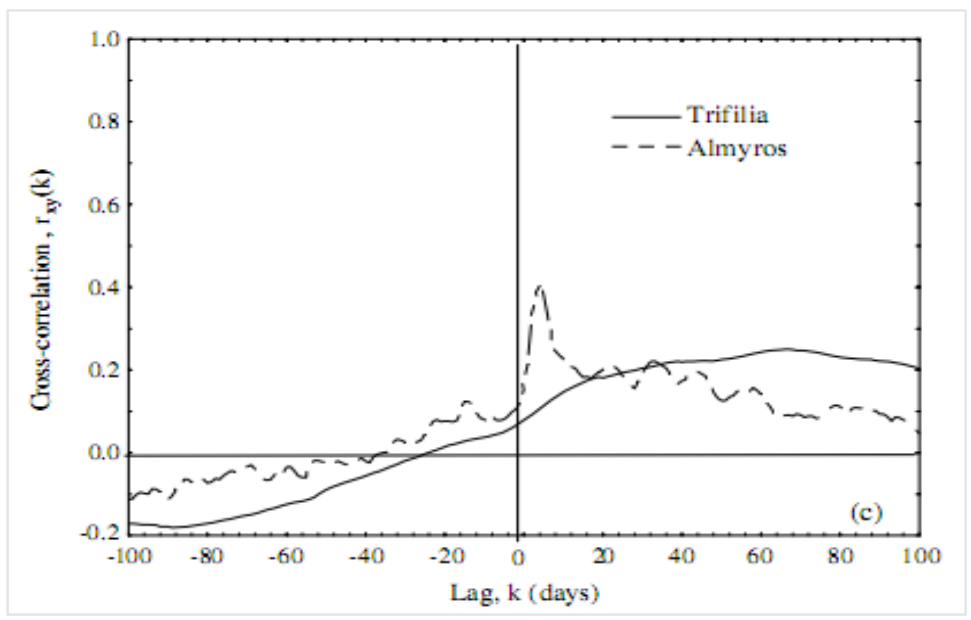

Gambar 2.12. Contoh cross-correlogram, Almyron merupakan karst yang berkembang sehingga memiliki $\mathrm{T}_{\text {lag }}$ yang lebih cepat dibandingkan Trifilias (Panagopoulus dan Lambarakis, 2006)

\section{Cross-Amplitude}

Nilai cross-correlation yang diubah dari satuan waktu menjadi frekuensi akan menghasilkan cross-amplitude. Persamaan metode ini adalah sebagai berikut:

$$
\begin{aligned}
& S_{x y}(f)=h_{x y}(f)-i \lambda_{x y}(f) \\
& h_{x y}(f)=2\left\{r_{x y}(0)+\sum_{1}^{m}\left[r_{x y}(k)+r_{y x}(k)\right] D(k) \cos (2 \pi f k)\right\} \\
& \lambda_{x y}(f)=2\left\{\sum_{1}^{m}\left[r_{x y}(k)-r_{y x}(k)\right] D(k) \sin (2 \pi f k)\right\} .
\end{aligned}
$$

$\mathrm{S}_{\mathrm{xy}}$ merupakan cross-amplitude yang menunjukkan seberapa lama input signal (hujan) difilter oleh sistem karst sebelum keluar sebagai output signal (debit aliran). Menurut Zang, dkk (2013), nilai tersebut menunjukkan Tlag maksimum sistem drainase karst dalam merespons hujan. Nilai tersebut terjadi ketika $S_{x y}$ mendekati 
nol. Karst yang telah berkembang akan mempunyai $\mathrm{T}_{\text {lag }}$ maksimum lebih cepat (Gambar 2.13).

\section{Phase Functions}

Phase functions merupakan hasil modifikasi dari cross-amplitude, persamaan tersebut adalah sebagai berikut:

$$
\theta_{x y}(f)=\arctan \frac{\lambda_{x y}(f)}{h_{x y}(f)}
$$

Nilai $\theta_{\mathrm{xy}}$ merupakan phase yang menunjukkan perbedaan frekuensi antara input signal dengan output signal. Perbedaan frekuensi ini terjadi karena adanya input signal (hujan) yang difilter oleh sistem karst. Nilai tersebut memiliki kegunaan yang komplemen dengan cross-correlation, yaitu menunjukkan waktu jeda terhadap aliran conduit. Waktu jeda (d) dari phase functions dihitung dengan persamaan berikut:

$$
d=\frac{\theta_{x y}(f)}{2 \pi f}
$$

Karst yang berkembang akan mempunyai nilai d yang lebih cepat dibandingkan karst yang belum berkembang (Gambar 2.14)

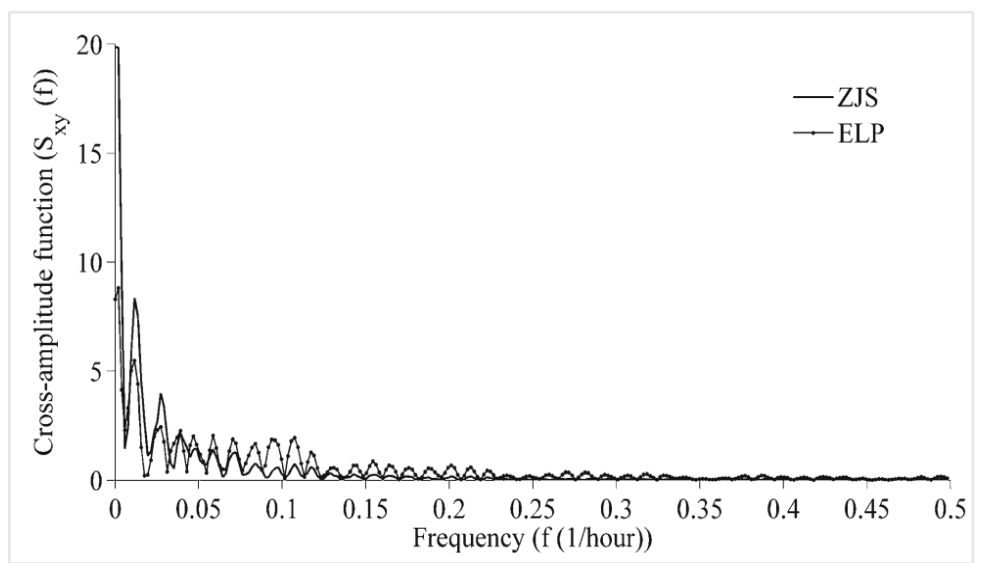

Gambar 2.13. Contoh grafik cross-amplitude, ELP merupakan karst berkembang yang memiliki nilai Sxy lebih cepat mendekati nol daripada ZJS (Zang, dkk, 2013).

\section{Gain-Functions}

Gain functions menunjukkan durasi dari quickflow, interflow, dan baseflow. Padilla dan Pulido-Bosch (1995) membuktikan bahwa gain yang bernilai satu 
menandakan berlakunya baseflow, nilai 0,4 menunjukkan berlakunya quickflow, dan diantara nilai keduanya berlaku interflow. Karst berkembang akan memiliki durasi quickflow, interflow, dan baseflow yang lebih cepat dibandingkan karst belum berkembang (Gambar 2.15). Persamaan dari fungsi ini adalah sebagai berikut:

$$
g_{x y}(f)=\frac{s_{x y}(f)}{S_{x}(f)}
$$
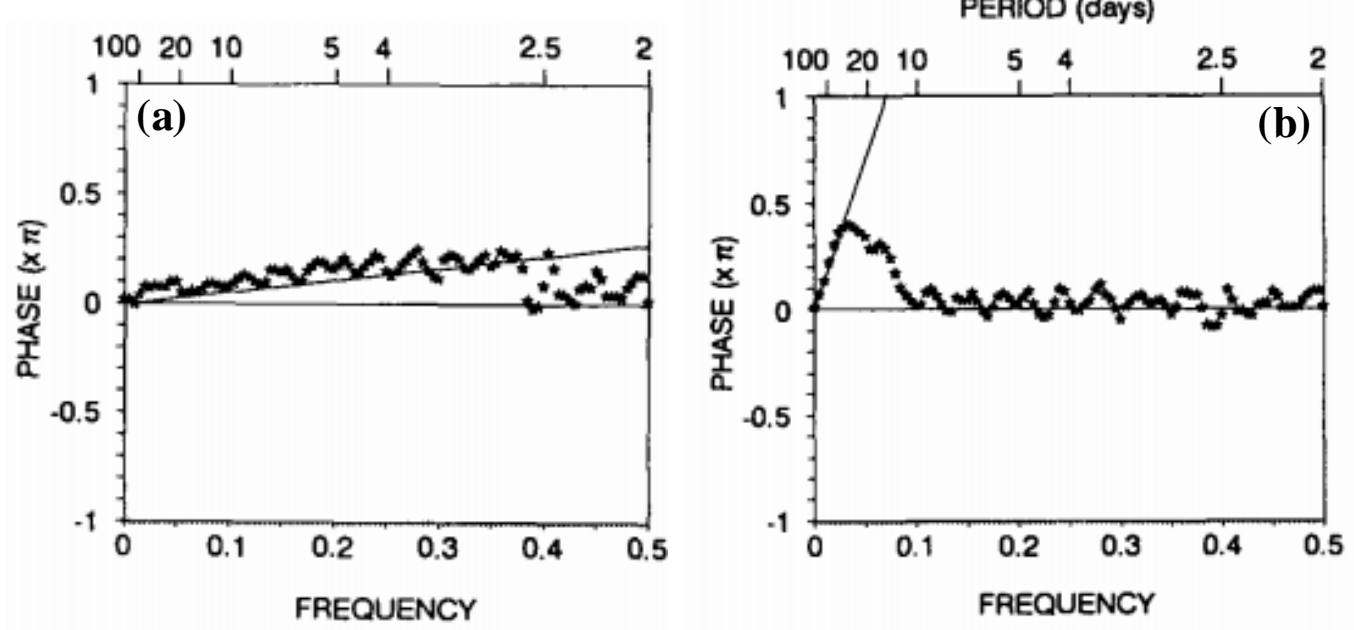

Gambar 2.14. Contoh grafik phase functions, (a) merupakan karst belum berkembang yang memiliki nilai phase lebih lambat daripada (b) yang merupakan karst berkembang (Padilla dan Pulido-Bosch, 1995).

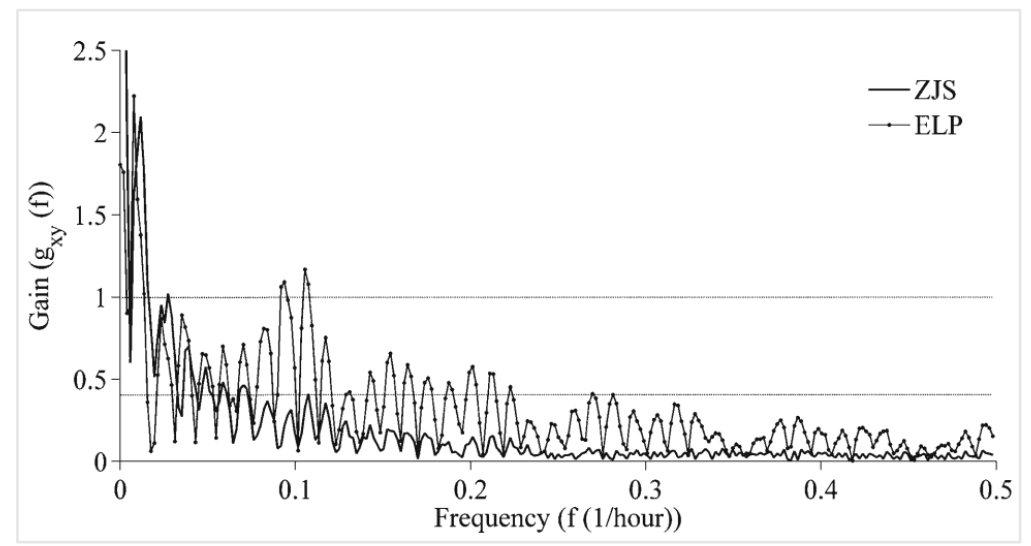

Gambar 2.15. Contoh grafik gain functions, ZJS merupakan karst belum berkembang yang memiliki nilai gain 1 dan 0,4 lebih lambat dibandingkan ELP yang merupakan karst berkembang (Zang, dkk, 2013) 


\subsubsection{Teknik Analisis Data}

\section{a. Analisis Data untuk Karakterisasi Pelepasan Komponen Aliran dan}

Prosentase Aliran Dasar

1. Analisis Deskriptif

Analisis deskriptif yang digunakan berupa grafik dan tabel. Rincian mengenai penggunaan grafik dan tabel pada analisis ini adalah sebagai berikut:

- Tabel:

- Tabel data pengukuran debit aliran dan TMA di Gua Pindul dan Sinking Stream Kedungbuntung.

- Tabel hasil perhitungan konstanta resesi di Gua Pindul dan Sinking Stream Kedungbuntung.

- Tabel prosentase aliran dasar perbulan selama enam bulan di Gua Pindul dan Sinking Stream Kedungbuntung.

- Tabel perbandingnan julat dan rerata nilai konstanta resesi antara Gua Pindul dengan Sinking Stream Kedungbuntung

- Tabel perbandingnan nilai dan rerata prosentase aliran dasar pada setiap kejadian banjir terpilih antara Gua Pindul dengan Sinking Stream Kedungbuntung

- Grafik:

- Grafik rating curve Gua Pindul dan Sinking Stream Kedungbuntung.

- Grafik debit dan curah hujan selama enam bulan Gua Pindul dan Sinking Stream Kedungbuntung.

- Grafik perhitungan nilai konstanta resesi pada setiap kejadian banjir terpilih di Gua Pindul dan Sinking Stream Kedungbuntung.

- Grafik perbandingan debit aliran dasar selama enam bulan di Gua Pindul dan Sinking Stream Kedungbuntung.

2. Analisis Statistik Inferensial

Statistik inferensial yang digunakan berupa regresi dan korelasi. Regresi digunakan untuk mencari rumus hubungan antara debit aliran dengan TMA di Gua Pindul dan Sinking Stream Kedungbuntung. Korelasi digunakan untuk mengetahui 
keeratan hubungan antar debit aliran dengan curah hujan di Gua Pindul dan Sinking Stream Kedungbuntung.

\section{Analisis Keruangan}

Analisis keruangan digunakan untuk membandingkan karakteristik pelepasan komponen aliran (tercermin melalui konstanta resesi) dan simpanan aliran dasar (tercermin melalui prosentase aliran dasar) dari Gua Pindul dan Sinking Stream Kedungbuntung.

4. Analisis Temporal

Analisis temporal digunakan untuk membandingkan karakteristik prosentase aliran dasar pada setiap kejadian banjir dan periode hujan (awal hujan pada bulan Januari-Februari, akhir hujan pada bulan Maret-April, dan awal kemarau pada Mei-Juni).

\section{b. Analisis Data untuk Karakterisasi Banjir}

\section{Analisis Deskriptif}

Analisis deskriptif yang digunakan berupa grafik dan tabel. Rincian mengenai penggunaan grafik dan tabel pada analisis ini adalah sebagai berikut:

- Tabel

- Tabel komponen hujan efektif di Gua Pindul dan Sinking Stream Kedungbuntung.

- Tabel perbandingan komponen hujan efektif antara Gua Pindul dengan Sinking Stream Kedungbuntung.

- Grafik:

- Grafik hidrograf banjir dan hyetograph pada kejadian banjir terpilih di Gua Pindul dan Sinking Stream Kedungbuntung.

- Grafik korelasi debit puncak dengan hujan efektif, hujan puncak, tebal hujan, dan durasi hujan di Gua Pindul dan Sinking Stream Kedungbuntung.

2. Analisis Statistik Inferensial

Statistik inferensial yang digunakan adalah korelasi. Metode ini digunakan untuk mencari keeratan hubungan antara debit puncak dengan tebal hujan, durasi hujan, hujan efektif, dan durasi hujan.

3. Analisis Keruangan 
Analisis keruangan digunakan untuk membandingkan karakteristik komponen hujan efektif dari Gua Pindul dan Sinking Stream Kedungbuntung.

4. Analisis Temporal

Analisis temporal digunakan untuk membandingkan karakteristik komponen hujan efektif pada periode hujan berbeda (awal hujan pada bulan Januari-Februari dan akhir hujan pada bulan Maret-April) di Gua Pindul dan Sinking Stream Kedungbuntung.

\section{c. Analisis Data untuk Karakterisasi Respons Debit Terhadap Hujan}

1. Analisis Deskriptif

Analisis deskriptif yang digunakan berupa grafik dan tabel. Rincian mengenai penggunaan grafik dan tabel pada analisis ini adalah sebagai berikut:

- Tabel perbandingan nilai time serien analysis antara Gua Pindul dan Sinking Stream Kedungbuntung

- Grafik perbandingan auto-correlation, spectral analysis, auto-correlation, cross-amplitude, phase function, gain function antara Gua Pindul dengan Sinking Stream Kedungbuntung.

\section{Analisis Keruangan}

Analisis keruangan digunakan untuk membandingkan karakteristik respons debit aliran terhadap curah hujan (tercermin melalui hasil time series analysis) dari Gua Pindul dan Sinking Stream Kedungbuntung.

\subsection{Tahapan Penelitian}

Penelitian ini berlangsung selama 7 bulan. Pengambilan data dilapangan berlangsung selama 6 bulan, yaitu pada 1 Januari 2017 hingga 30 Juni 2017. Pengolahan data, analisis data, dan pembuatan laporan penelitian berlangsung selama satu bulan, yaitu Juli 2017. Tahapan penelitian dapat dilihat secara sistematis pada Gambar 2.16. Uraian tahapan penelitian ini adalah sebagai berikut:

\subsubsection{Tahap Pra-Lapangan}

a. Studi literatur dilakukan untuk memahami teori mengenai kajian penelitian.

b. Survei lapangan dilakukan untuk lebih mengenali lokasi penelitian. 


\subsubsection{Tahap Lapangan}

a. Pemasangan alat logger muka air di Gua Pindul dan Sinking Stream Kedungbuntung, logger muka air kalibrasi, dan logger hujan

b. Pengukuran debit aliran setiap dua minggu sekali dan ketika terjadi banjir.

\subsubsection{Tahap Paska Lapangan}

a. Pembuatan rating curve untuk mendapatkan data debit secara kontinu

b. Perhitungan konstanta resesi dari hidrograf banjir terpilih.

c. Pemisahan aliran dasar untuk mendapatkan data PAD.

d. Perhitungan time series analysis.

e. Perhitungan hujan efektif.

f. Penyusunan laporan penelitian. 


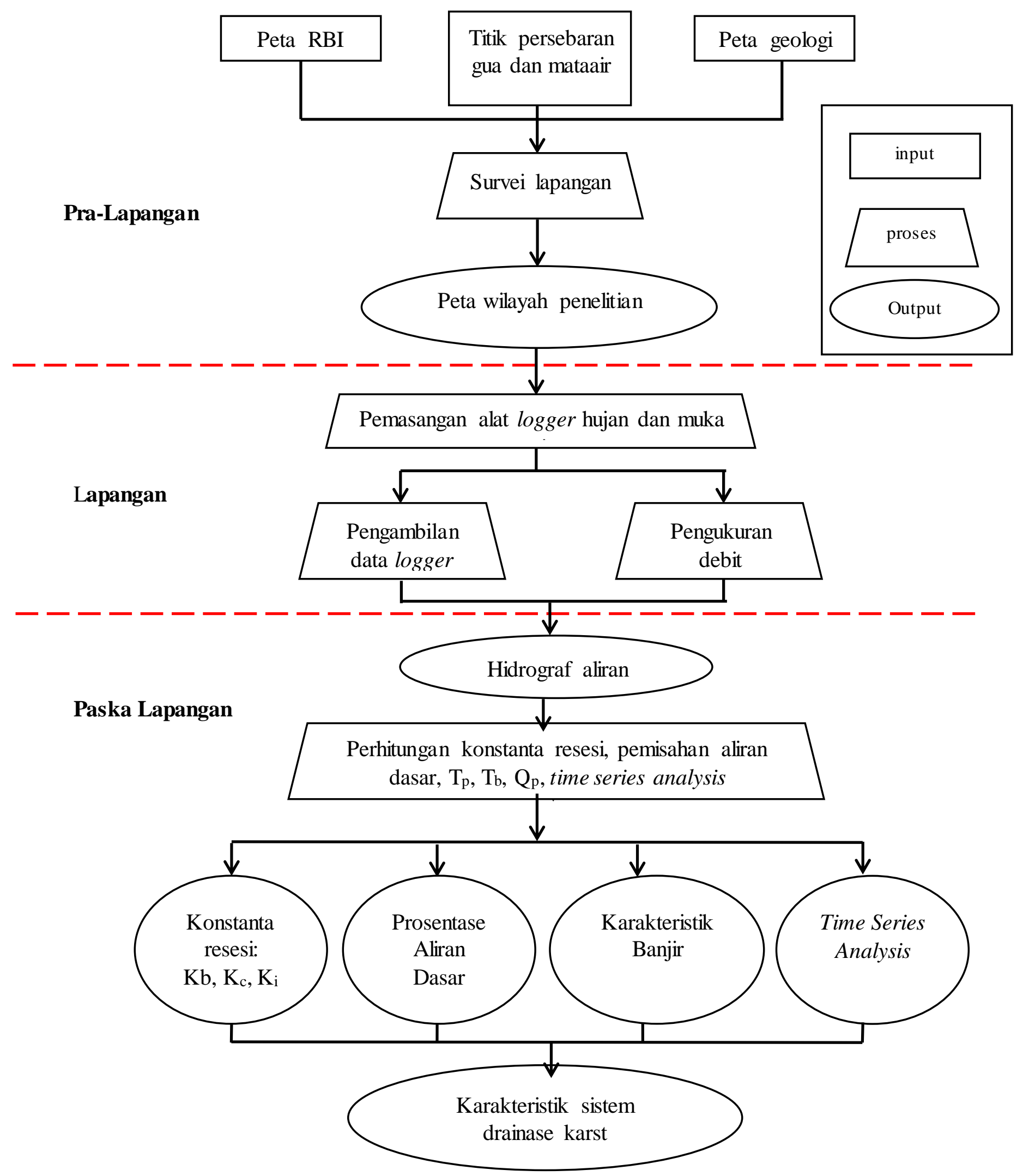

Gambar 2.16. Diagram alir penelitian 


\section{BAB III}

\section{DESKRIPSI WILAYAH}

\subsection{Letak, Batas, dan Luas Daerah Penelitian}

Sistem Drainase Karst Pindul secara administratif berada di Kecamatan Karangmojo, Kabupaten Gunungkidul. Gambar 3.1 menunjukkan lokasi relatif dan absolut dari Sistem Pindul dan Kecamatan Karangmojo. Lokasi absolut Kecamatan Karangmojo berada pada zona 49M dengan koordinat 9117000 - 9129000 mT dan 457500 - $468000 \mathrm{mU}$. Secara relatif, Kecamatan Karangmojo dibatasi oleh:

- Sebelah Utara dibatasi oleh Kecamatan Nglipar, Ngawen, dan Semin;

- Sebelah Barat dibatasi oleh Kecamatan Wonosari;

- Sebelah Timur dibatasi oleh Kecamatan Ponjong;

- Sebelah Selatan dibatasi oleh Kecamatan Semanu.

Kecamatan Karangmojo memiliki luas $80,12 \mathrm{~km}^{2}$ atau 5,39\% dari luas Kabupaten Gunungkidul (BPS, 2016). Terdapat sembilan desa yang menjadi bagian wilayah administrasi kecamatan ini. Tabel 3.1 menunjukkan nama desa dan luasannya.

Desa Bejiharjo memiliki luas terbesar di kecamatan ini. Sementara itu, Bejiharjo, Bendungan, dan Ngawis merupakan tiga desa terluas di dalam Sistem Drainase Karst Gua Pindul. Sistem Drainase Karst Pindul (15,44 km²) dikategorikan menjadi zona diffuse (luas $13,69 \mathrm{~km}^{2}$ ) dan zona conduit (luas 1,75 $\mathrm{km}^{2}$ ) (Agniy, 2016). Zona conduit memiliki ciri adanya sistem perguaan yang seluruhnya berada di Desa Bejiharjo (Gambar 3.1).

\subsection{Kondisi Iklim}

\subsubsection{Curah Hujan}

Data hujan didapatkan dari Balai Besar Wilayah Sungai Serayu-OpakProgo (BBWS SOP). Stasiun hujan tersebut berada di Kecamatan Karangmojo dengan zona 49M serta koordinat $465066 \mathrm{mT}$ dan $9121913 \mathrm{mU}$. Tabel 3.2 menunjukkan data hujan selama 10 tahun (2006-2015).

Gambar 3.2 menunjukkan bahwa wilayah kajian memiliki musim penghujan pada bulan Oktober-April dan musim kemarau pada Mei-September. 
Hal tersebut dipengaruhi oleh adanya angin monsoon di Indonesia. Sementara itu, rerata hujan tahunan di wilayah kajian adalah $1752 \mathrm{~mm}$, dengan anomali hujan terkecil terjadi pada tahun 2007 dan terbesar pada tahun 2013.

PETA ADMINISTRASI SISTEM DRAINASE KARST PINDUL

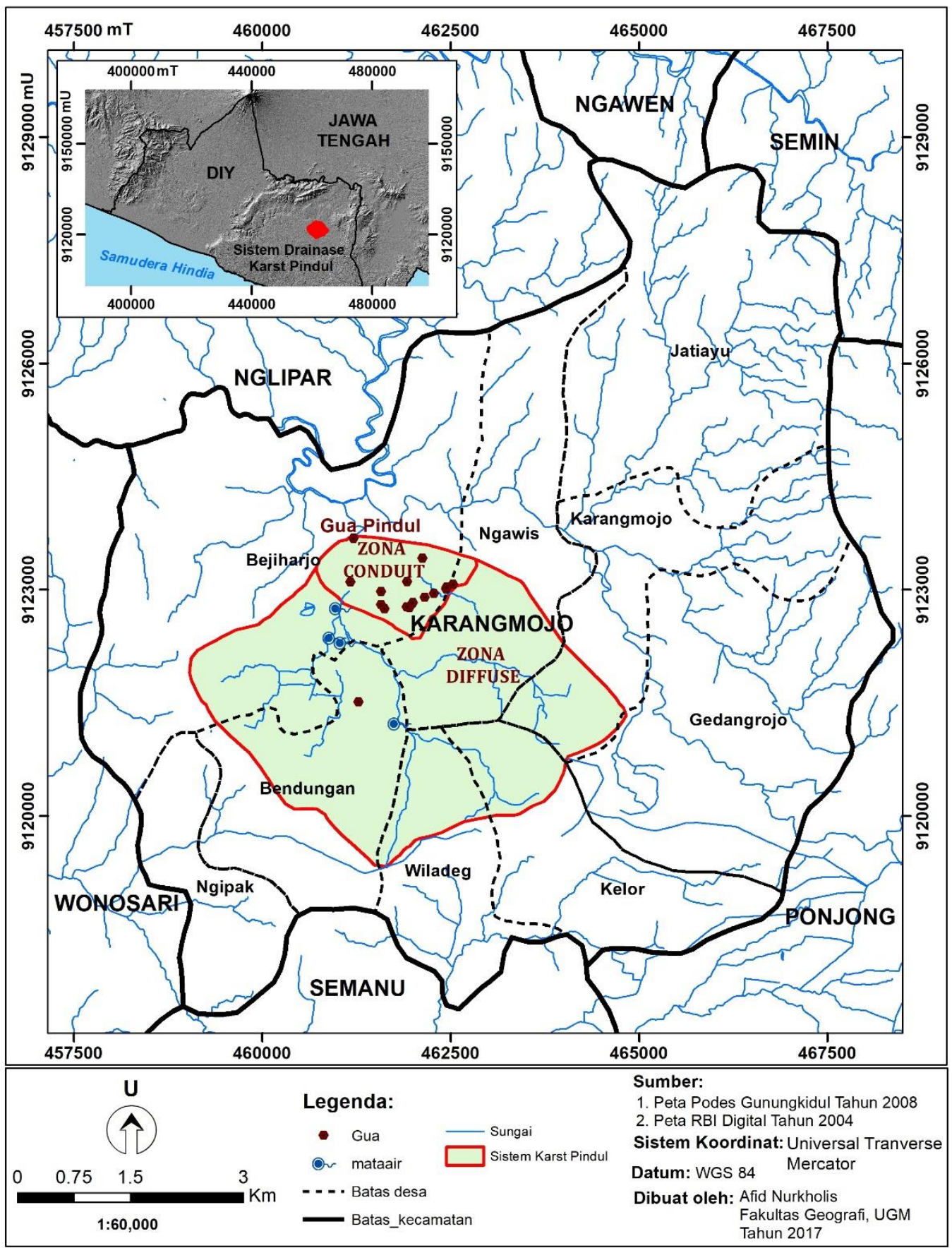

Gambar 3.1. Peta administrasi wilayah kajian 
Tabel 3.1. Luas desa di Kecamatan Karangmojo

(BPS, 2016 dan pengolahan data tahun 2017)

\begin{tabular}{llllll}
\hline No. & Desa & $\begin{array}{l}\text { Luas } \\
\left(\mathrm{km}^{2}\right)\end{array}$ & $\begin{array}{l}\text { \% Luas desa } \\
\text { terhadap } \\
\text { kecamatan }\end{array}$ & $\begin{array}{l}\text { Luas } \\
\text { terhadap } \\
\text { DTA }\left(\mathrm{km}^{2}\right)\end{array}$ & $\begin{array}{l}\text { \% Luas } \\
\text { terhadap } \\
\text { DTA }\end{array}$ \\
\hline 1 & Bendungan & 6,51 & 3,68 & 3,55 & 22,95 \\
2 & Bejiharjo & 22,01 & 27,47 & 4,52 & 29,22 \\
3 & Wiladeg & 6,95 & 8,67 & 1,47 & 9,50 \\
4 & Kelor & 3,68 & 4,59 & 1,29 & 8,34 \\
5 & Ngipak & 5,31 & 6,63 & 0 & 0 \\
6 & Karangmojo & 11,15 & 13,92 & 1,34 & 8,66 \\
7 & Gedangrejo & 6,91 & 8,63 & 0 & 0 \\
8 & Ngawis & 8,35 & 10,42 & 3,30 & 21,33 \\
9 & Jatiayu & 12,81 & 15,99 & 0 & 0 \\
\hline Jumlah & 80,12 & 100 & 15,47 & 100 \\
\hline
\end{tabular}

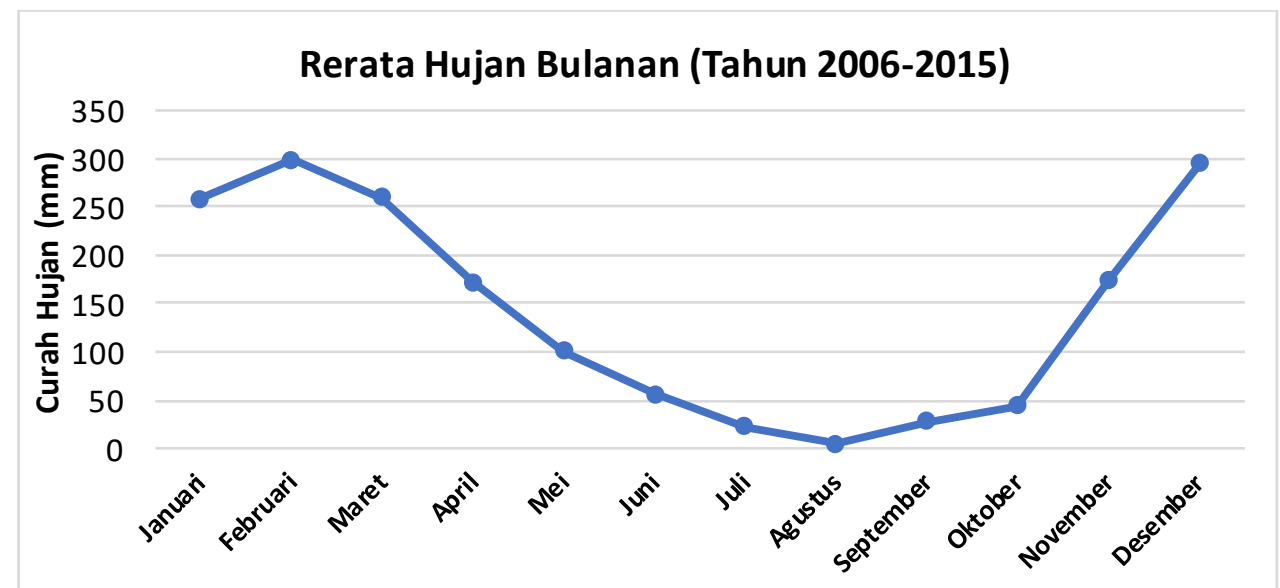

Gambar 3.2. Rerata hujan bulanan Stasiun Karangmojo (BBWS, 2006-2015)

\subsubsection{Suhu dan Kelembapan Udara}

Suhu dan kelembapan udara di wilayah kajian dipengaruhi oleh letaknya yang berada di khatulistiwa. Matahari berada di atas khatulistiwa pada rentang bulan Maret-April-Mei dan September-Oktober-November (Garrison, 2011). Tabel 3.3 menunjukkan rerata suhu udara bulanan wilayah kajian selama enam bulan pengukuran lapangan (Januari-Juni). Suhu udara pada bulan Januari-FebruariMaret memiliki nilai sekitar $26^{\circ} \mathrm{C}$, sedangkan pada bulan April-Mei-Juni memiliki nilai sekitar $27^{\circ} \mathrm{C}$. Kelemababan udara relatif dihitung dengan membandingkan muatan uap air di udara dengan jumlah maksimum uap air yang dapat dimuat udara pada suhu tertentu. Menurut Strahler (2011), suhu udara yang lebih tinggi mampu memuat uap air lebih besar. 
Tabel.3.2. Data hujan selama 10 tahun: (a) Rerata setiap bulan, (b) Hujan tahunan (BBWS, 2006-2015)

\begin{tabular}{|c|c|c|c|c|c|}
\hline (a) No & Bulan & $\begin{array}{l}\text { Rerata } \\
\text { Hujan } \\
(\mathrm{mm})\end{array}$ & (b) $\mathrm{No}$ & Tahun & $\begin{array}{l}\text { Hujan } \\
(\mathrm{mm})\end{array}$ \\
\hline 1 & Januari & 259 & 1 & 2006 & 1703 \\
\hline 2 & Februari & 299 & 2 & 2007 & 926 \\
\hline 3 & Maret & 260 & 3 & 2008 & 1788 \\
\hline 4 & April & 172 & 4 & 2009 & 1558 \\
\hline 5 & Mei & 100 & 5 & 2010 & 2107 \\
\hline 6 & Juni & 56 & 6 & 2011 & 1744 \\
\hline 7 & Juli & 23 & 7 & 2012 & 1937 \\
\hline 8 & Agustus & 5 & 8 & 2013 & 2204 \\
\hline 9 & September & 27 & 9 & 2014 & 1701 \\
\hline 10 & Oktober & 44 & 10 & 2015 & 1851 \\
\hline 11 & November & 173 & \multicolumn{2}{|c|}{ Rerata } & 1752 \\
\hline 12 & Desember & 296 & \multicolumn{2}{|c|}{$\operatorname{Max}$} & 2204 \\
\hline & & & \multicolumn{2}{|l|}{ Min } & 926 \\
\hline
\end{tabular}

Tabel 3.3 menunjukkan bahwa semakin tinggi suhu udara maka kelembapan udara semakin rendah. Hal ini diakibatkan oleh semakin besarnya kapasitas maksimum udara untuk memuat uap air. Kelembapan udara di wilayah kajian memiliki julat 77,8-86,6\% dengan rerata $86,1 \%$. Suhu dan kelembapan udara di Sistem Drainase Karst Pindul dapat dilihat pada Gambar 3.3.

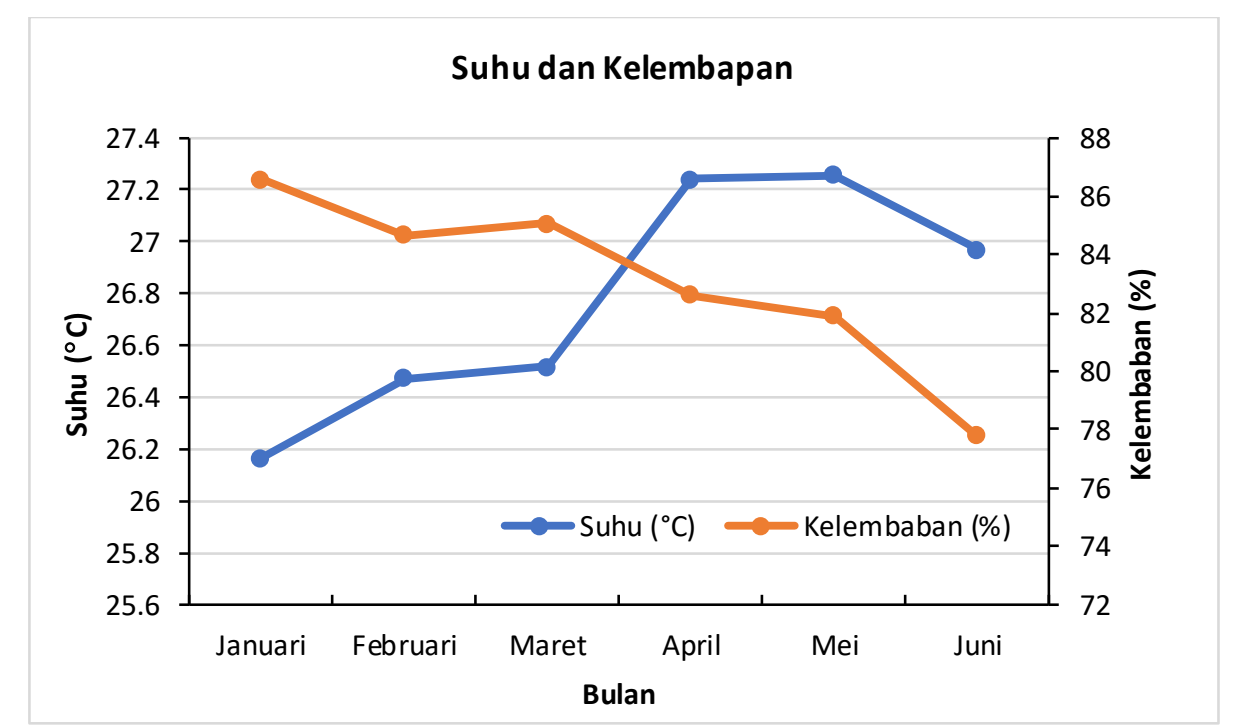

Gambar 3.3. Suhu dan kelembapan udara wilayah kajian 
Tabel 3.3. Suhu dan kelembapan udara wilayah kajian (pengukuran lapangan, 2017)

\begin{tabular}{lll}
\hline Bulan & Suhu $\left({ }^{\circ} \mathrm{C}\right)$ & Kelembaban $(\%)$ \\
\hline Januari & 26,2 & 86,6 \\
Februari & 26,5 & 84,7 \\
Maret & 26,5 & 85,1 \\
April & 27,2 & 82,6 \\
Mei & 27,3 & 81,9 \\
Juni & 27,0 & 77,8 \\
\hline Rerata & 26,8 & 83,1 \\
Max & 27,3 & 86,6 \\
Min & 26,2 & 77,8 \\
\hline
\end{tabular}

\subsection{Kondisi Geologi}

\subsubsection{Fisiografi}

Pegunungan Selatan Jawa Timur bagian barat merupakan salah satu zona dalam fisiografi Pulau Jawa menurut Bemmelen (1949). Zona tersebut selanjutnya dibagi lagi menjadi tiga subzona (Gambar 3.4). Subzona paling selatan adalah Karst Gunungsewu dengan material penyusun utama batugamping dari Formasi Wonosari dengan arah barat-timur. Basin Wonosari merupakan subzona tengah dengan material utama batugamping dari Formasi Wonosari dan napal pasiran dari Formasi Kepek. Subzona bagian utara adalah rangkaian Pegunungan Baturagung, Masif Panggung, dan Punggungan Plopoh dengan material utama batuan gunungapi tua. Gambar 3.4. menunjukkan bahwa Sistem Drainase Karst Pindul terletak di Basin Wonosari.

\subsubsection{Stratigrafi}

Material penyusun Zona Pegunungan Selatan dapat dikelompokkan menjadi batuan vulkanik dan karbonat (Suyoto, 1994 dalam Kusumayudha, 2005). Grup batuan vulkanik terdiri dari Formasi Kebobutak, Semilir, dan Nglanggran. Grup karbonat terdiri dari Formasi Sambipitu, Oyo, Wonosari, dan Kepek. Rahaningmas (2013) melakukan penelitian mengenai stratigrafi lokal wilayah Gua Pindul dan sekitarya. Gambar 3.5 menunjukkan wilayah penelitian ini terdiri dari empat litofasies. Gambar 3.6 menunjukkan hubungan stratigrafinya. Penjelasan dengan urutan dari umur tertua ke yang muda adalah sebagai berikut: 


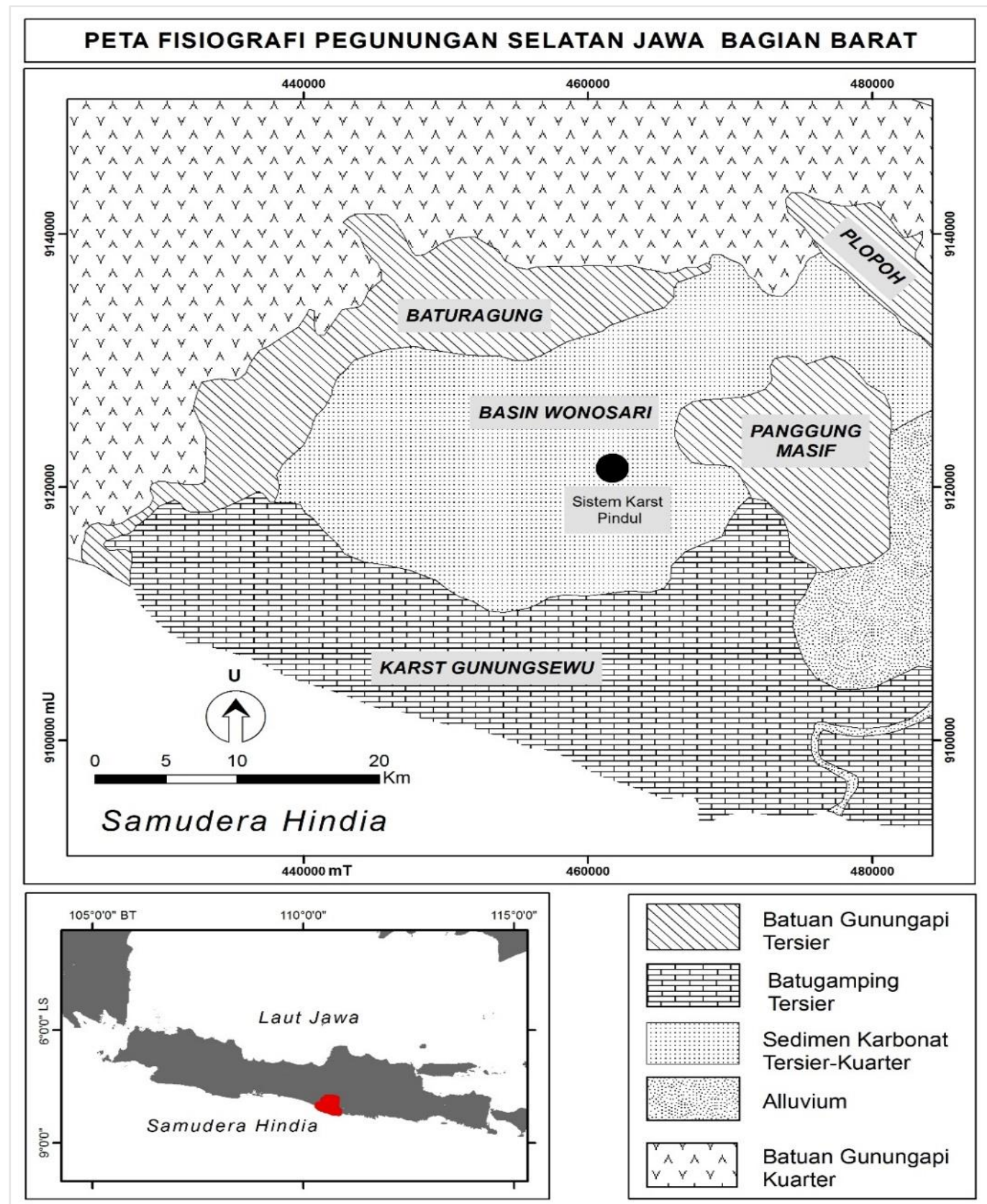

Gambar 3.4. Fisiografi Zona Pegunungan Selatan Jawa Timur Bagian Barat (Bemmelen, 1949)

1. Tuff

Satuan Tuff merupakan yang paling tua di lokasi peneltitian dengan perkiraan berumur Miosen Bawah. Satuan ini secara regioal sebanding dengan Formasi Semilir. Batas satuan tuff dengan satuan diatasnya ditandai dengan perubahan endapan lingkungan laut dalam dengan tidak selaras. 


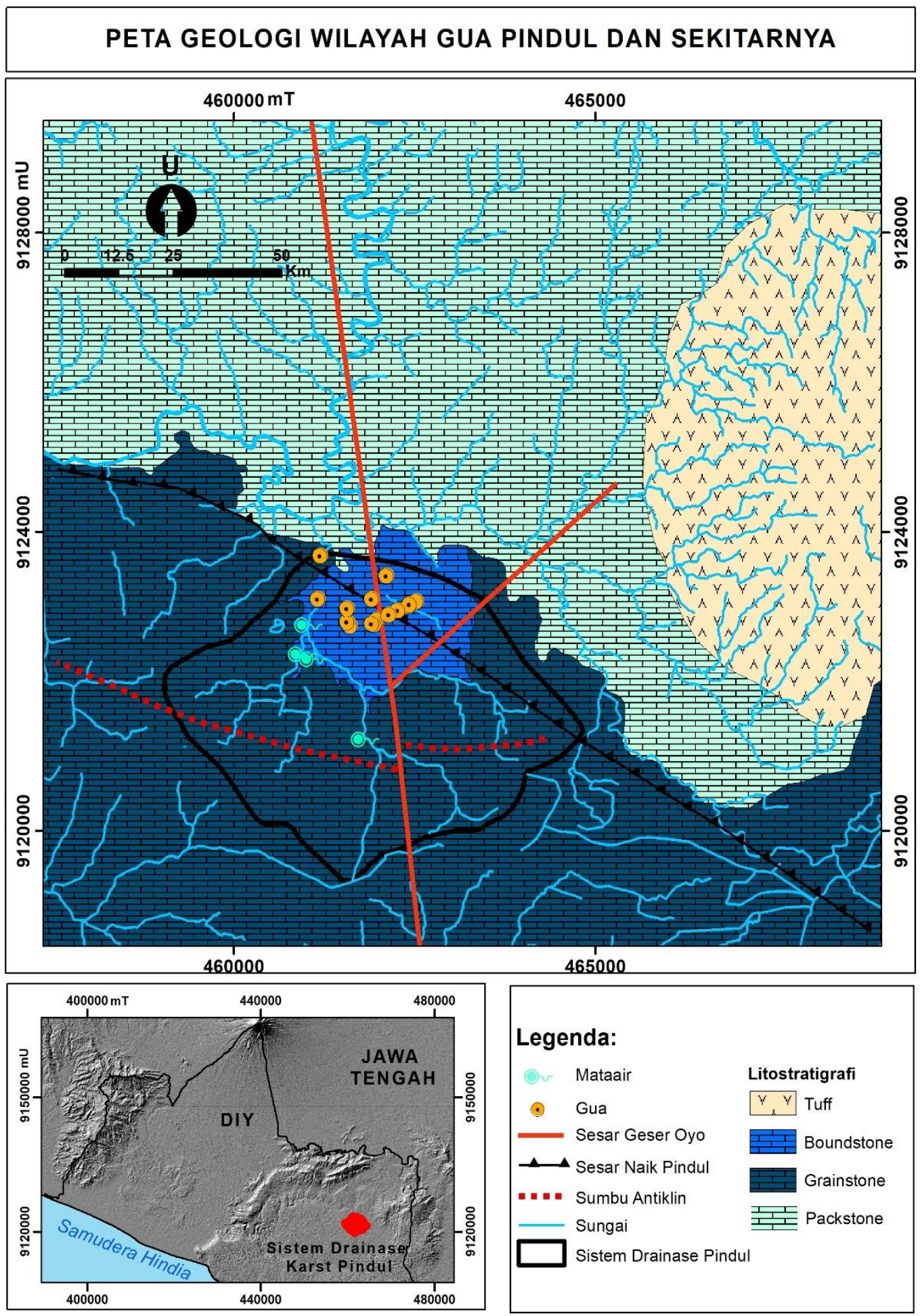

Gambar 3.5. Peta Geologi wilayah Gua Pindul dan sekitarnya (Rahaningmas, 2013) 


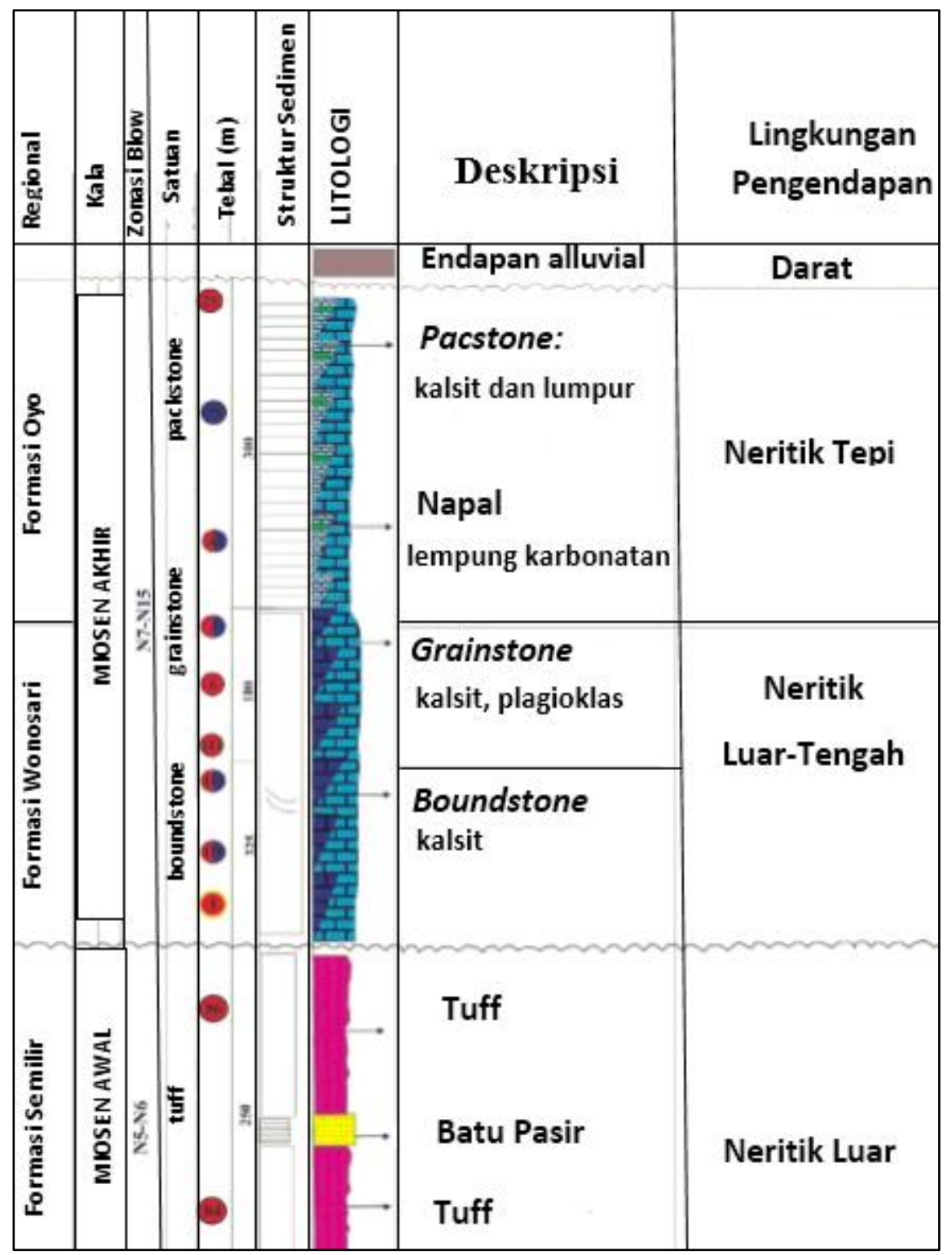

Gambar 3.6. Kolom stratigrafi wilayah Gua Pindul dan sekitarnya (Rahaningmas, 2013)

\section{Boundstone}

Satuan boundstone merupakan batugamping terumbu yang diendapkan kala Miosen Bawah-Miosen Tengah. Satuan ini ditandai dengan perubahan endapan lingkungan laut dalam. Hubungan dengan satuan tuff dibawahnya adalah tidak selaras, sedangkan dengan satuan diatasnya adalah saling memasuki/menjari. 


\section{Grainstone}

Satuan grainstone merupakan batugamping karbonat dengan ukuran butir pasir kasar-halus yang diendapkan pada kala Miosen Tengah. Satuan ini diendapkan pada lingkungan laut neritik. Hubungan dengan satuan boundstone (di bawahnya) dan satuan packstone (di atasnya) adalah saling memasuki/menjari.

4. Packstone

Satuan packstone merupakan batugamping terumbu yang disisipi napal. Satuan ini merupakan yang paling muda, yaitu diendapkan kala Miosen Atas. Satuan ini diendapkan di lingkungan neritik tepi. Satuan packstone sebanding dengan Formasi Oyo.

\subsubsection{Struktur Geologi}

Struktur geologi yang ada di wilayah penelitian terdiri dari kekar, lipatan, dan sesar (Rahaningmas, 2013). Struktur kekar terdiri dari kekar tarik dan kekar gerus. Kekar gerus terbentuk akibat adanya gaya kompresi/tekan. Kekar ini terebentuk menyudut terhadap datangnya arah gaya utama dan terdiri dari sepasang arah. Kekar tarik terbentuk akibat bekerjanya gaya tarik. Kekar ini bersifat terbuka dan tidak berpasangan. Kedua kekar dijumpai pada litofasies grainstone.

Gambar 3.5 menunjukkan letak struktur lipatan dan sesar. Sesar Oyo merupakan sesar geser utama dengan arah relatif Utara-Selatan. Sesar Pindul merupakan sesar naik yang bersifat lokal dengan arah relatif Barat-Timur. Lipatan yang ada di wilayah penelitian dipengaruhi oleh geologi regional Pegunungan Selatan. Struktur tersebut adalah Antiklin Grogol yang memiliki arah relatif Barat Laut-Tenggara dengan kemiringan berlawanan.

\subsection{Kondisi Geomorfologi}

Hasil observasi lapangan dan analisis data morfologi, material penyusun, serta proses geomorfologi menunjukkan Sistem Drainase Karst Pindul memiliki dua satuan bentuklahan (Gambar 3.7). Penjelasan kedua satuan tersebut adalah sebagai berikut: 


\section{Karst Berkembang}

Bentuklahan karst berkembang dicirikan dengan adanya gua-gua yang saling berhubung. Menurut Haryono (2014), Gua Asri, Gua Greng, Gua Emas, Gua Candi, Gua Suruh, dan Gua Sioyot saling terhubung dari Timur ke Barat untuk selanjutnya bermuara di Gua Pindul (Gambar 3.9). Litologi penyusun satuan ini adalah boundstone yang tergolong batu gamping terumbu. Secara hidrogeologi, wilayah ini disebut zona conduit oleh Agniy (2016). Gua-gua yang saling terhubung di atas membentuk sungai bawah tanah yang memiliki karakteristik seperti sungai permukaan.

2. Karst Tidak Berkembang

Karst tidak berkembang dicirikan dengan material bawah permukaan yang homogen, munculnya mataair diffuse, dan adanya sungai permukaan perennial. Material yang homogen tersebut dibuktikan dengan dapat dilakukannya pumping test dan pembuatan peta flownet oleh Agniy (2016). Mataaair diffuse terdapat di Mataair Kali Banteng dan Beji yang tidak keruh meskipun terjadi hujan. Sungai permukaan yang tidak pernah kering menunjukkan adanya aliran baseflow yang mensuplainya ketka musim kemarau.

\subsection{Kondisi Tanah}

Data peta tanah dari Balai Pengkajian Teknologi Pertanian (BPTP) DIY Tahun 2015 menunjukkan bahwa wilayah kajian memiliki empat jenis tanah (Gambar 3.8). Karakteristik setiap jenis tanah dapat dilihat pada Tabel 3.4. Seluruh tanah yang ada memiliki ketabalan yang tipis $(<50 \mathrm{~cm})$. Hal ini disebabkan oleh bahan induk yang berupa batuan gamping (terumbu dan karbonat) sehingga proses solusional lebih dominan daripada pelapukan. Tanah dengan material batugamping terumbu memiliki permeabilitas lebih baik daripada tanah bermaterial batugamping karbonat. Hal ini disebabkan oleh batugamping karbonat mengandung pengotor lempung dan pasir (litofasies grainstone). Karakteristik tanah ini memengaruhi imbuhan air ke zona epikarst Sistem Drainase Karst Pindul. 


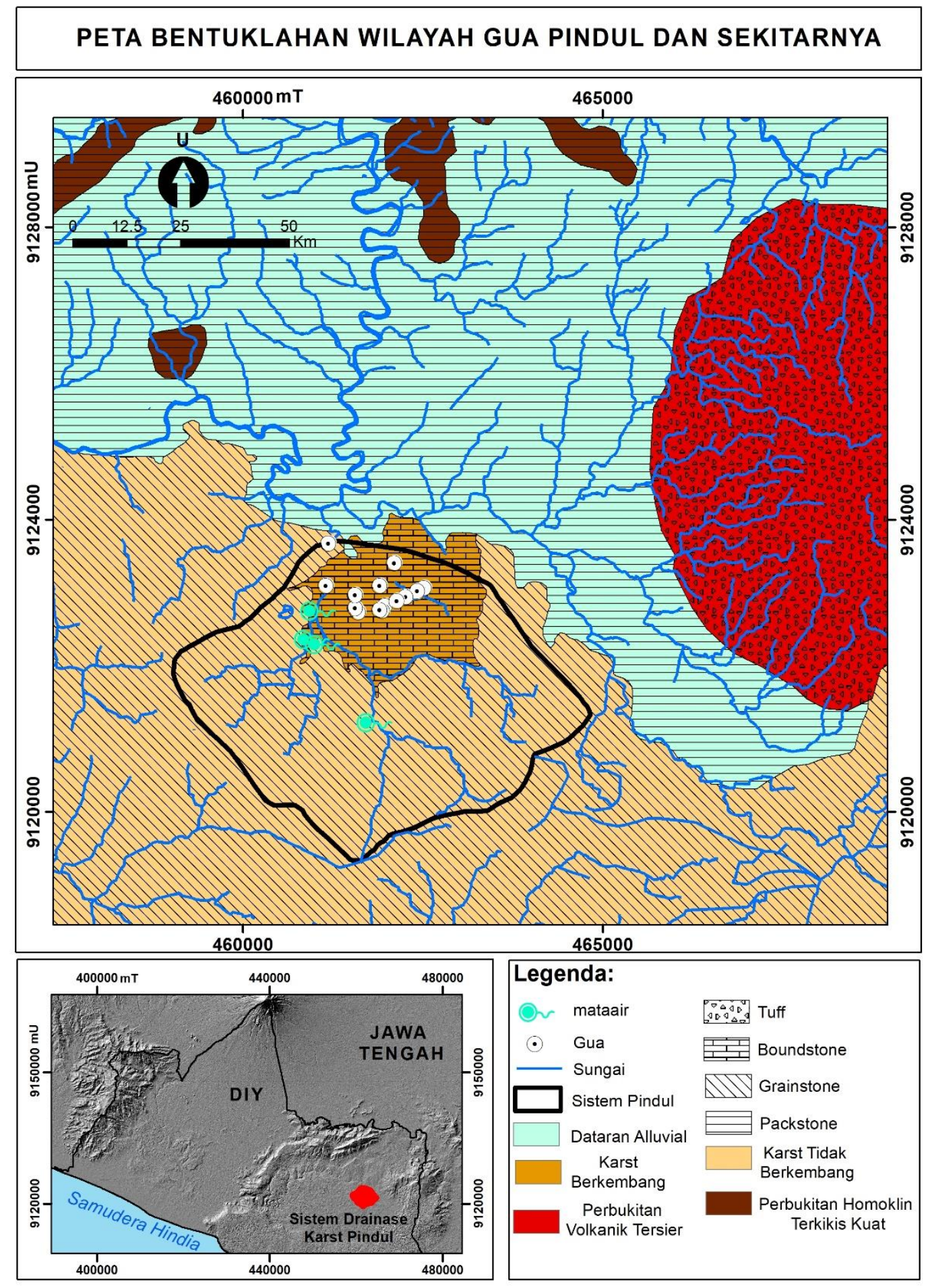

Gambar 3.7. Peta Bentuklahan wilayah Gua Pindul dan sekitarnya (Observasi Lapangan dan Analisis Data, 2017) 


\subsection{Kondisi Penggunaan Lahan}

Tabel 3.5 menunjukkan bahwa tegalan, pemukiman, dan sawah irigasi merupakan aktifitas manusia yang dominan di Sistem Karst Pindul. Tegalan memiliki luas terbesar mengingat karakteristik wilayah karst yang memiliki tanah tipis. Sawah irigasi berada di zona conduit (Gambar 3.9) yang berhubungan dengan adanya sumber air dari sungai bawah tanah untuk dijadikan irigasi. Keberadaan sistem perguaan di zona conduit dimanfaatkan masyarakat sebagai obyek wisata. Gua Pindul di outlet sistem karst dan Gua Tanding di sinking stream Kedungbuntung merupakan ikon wisata di wilayah ini. Sementara itu, zona diffuse memiliki mata air yang tidak pernah kering sepanjang tahun. Mataair ini dimanfaatkan oleh masyarakat untuk kegiatan sehari-hari, seperti mandi, mencuci, dan memandikan ternak.

Tabel 3.4. Karakteristik jenis tanah di Sistem Pindul (BPTP DIY, 2015)

\begin{tabular}{lllllll}
\hline Jenis Tanah & Bahan Induk & Tekstur & $\begin{array}{l}\text { Kedalaman } \\
(\mathrm{cm})\end{array}$ & Permeabilitas & Konsistensi & $\begin{array}{l}\text { Luas } \\
\left(\mathrm{km}^{2}\right)\end{array}$ \\
\hline $\begin{array}{l}\text { Typic } \\
\text { Eutropepts } \\
\text { Lithic }\end{array}$ & $\begin{array}{l}\text { Batugamping } \\
\text { terumbu }\end{array}$ & Lempung & $<50$ & Sedang & Teguh & 2 \\
$\begin{array}{l}\text { Haplustols } \\
\text { Bypic }\end{array}$ & $\begin{array}{l}\text { Terumbu } \\
\text { Kompleks } \\
\text { Hapluderts }\end{array}$ & $\begin{array}{l}\text { Lempung } \\
\text { endapan liat } \\
\text { dan }\end{array}$ & $<50$ & Sedang & Teguh & 3 \\
& $\begin{array}{l}\text { Latugamping } \\
\text { karbonat }\end{array}$ & & & Lambat & Teguh & 4 \\
& $\begin{array}{l}\text { Batugamping } \\
\text { karbonat }\end{array}$ & Lempung & $<50$ & & & \\
$\begin{array}{l}\text { Lithic } \\
\text { Ustropepts }\end{array}$ & & & Agak Lambat & Teguh & 6 \\
\hline
\end{tabular}

Tabel 3.5. Luas penggunaan lahan di Sistem Pindul (Peta Podes, 2008; Citra Geo Eye 2015, Survei Lapangan 2017)

\begin{tabular}{cccc} 
No & Penggunaan Lahan & Luas $\left(\mathrm{km}^{2}\right)$ & $\%$ \\
\hline 1 & Kebun & 0,02 & 0,15 \\
2 & Pemukiman & 4,87 & 31,57 \\
3 & Rumput & 0,02 & 0,13 \\
4 & Sawah irigasi & 1,13 & 7,35 \\
5 & Tegalan & 9,37 & 60,68 \\
6 & Tubuh Air & 0,02 & 0,12 \\
\hline
\end{tabular}




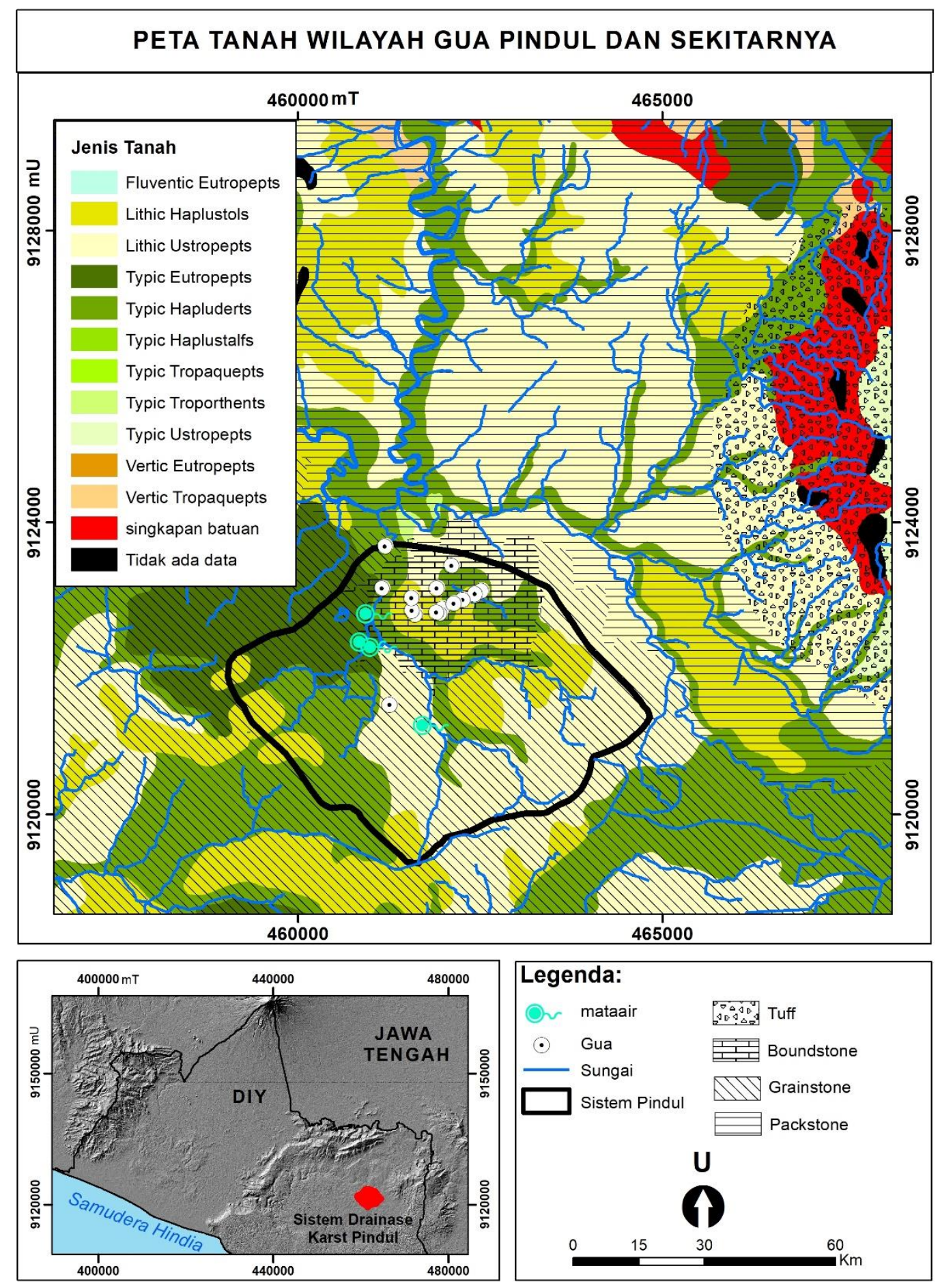

Gambar 3.8. Peta Tanah wilayah Pindul dan sekitarnya (BPTP, 2015) 


\section{PETA PENGGUNAAN LAHAN SISTEM DRAINASE KARST PINDUL}

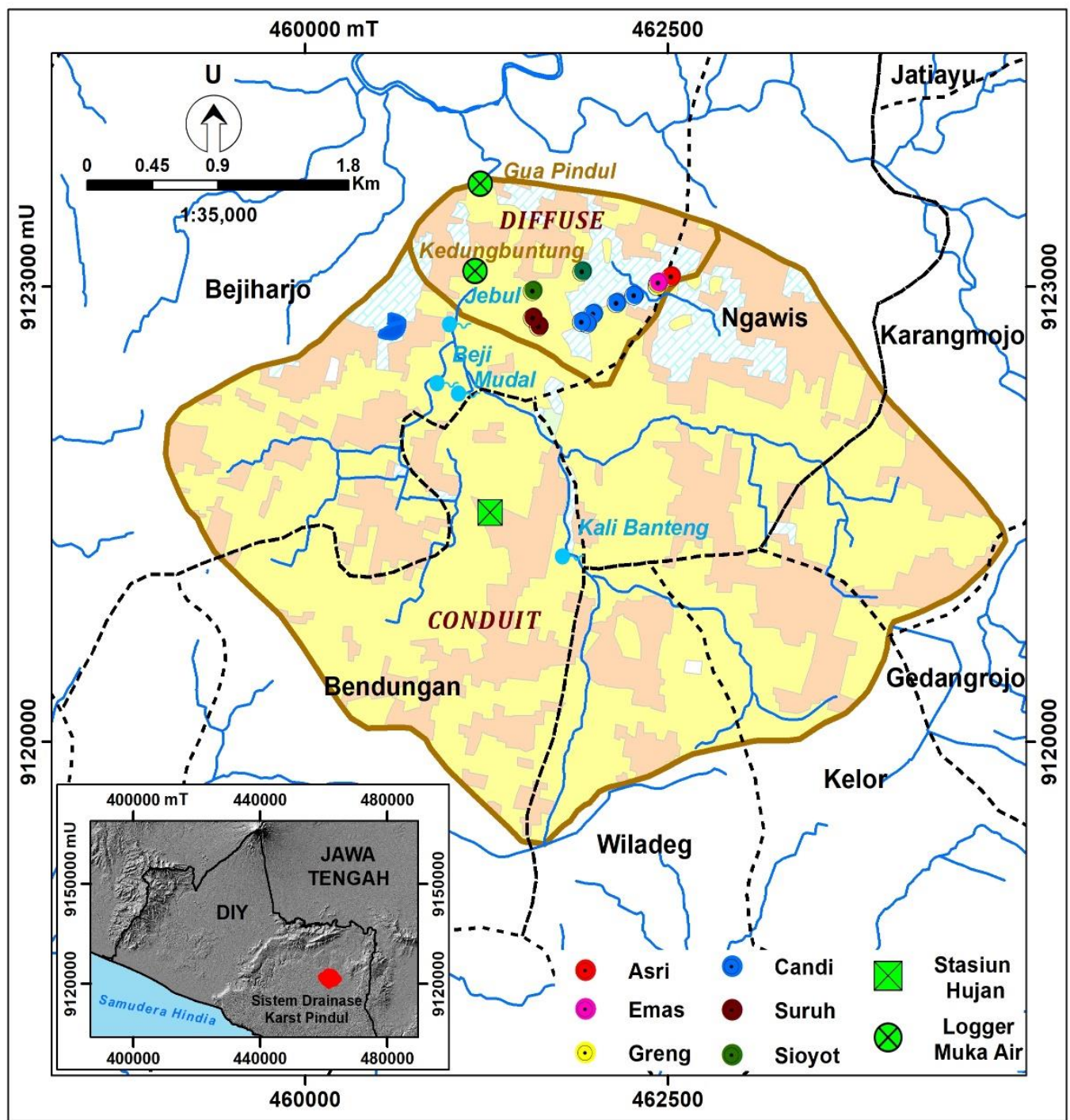

\begin{tabular}{|c|c|c|}
\hline \multirow{7}{*}{$\begin{array}{l}\text { Legenda: } \\
\text { Mataair } \\
\text { Sungai } \\
\text { Sistem Karst Pindul }\end{array}$} & Penggunaan Lahan & Sumber: \\
\hline & Kebun & $\begin{array}{l}\text { 1. Peta Podes Gunungkidul Tahun } 2008 \\
\text { 2. Peta RBI Digital Tahun } 2004\end{array}$ \\
\hline & Permukiman & \multirow{2}{*}{$\begin{array}{c}\text { Sistem Koordinat: Universal Tranverse } \\
\text { Mercator }\end{array}$} \\
\hline & Rumput & \\
\hline & Sawah irigasi & Datum: WGS 84 \\
\hline & Tegalan & \multirow{2}{*}{$\begin{array}{l}\text { Afid Nurkholis } \\
\text { Fakultas Geografi, UGM } \\
\text { Tahun } 2017\end{array}$} \\
\hline & Tubuh air & \\
\hline
\end{tabular}

Gambar 3.9. Peta Penggunaan Lahan Sistem Drainase Karst Pindul (Peta Podes, 2008; Citra Geo Eye 2015, Survei Lapangan 2017) 


\section{BAB IV \\ HASIL DAN PEMBAHASAN}

\subsection{Karakteristik Pelepasan Komponen Aliran dan Prosentase Aliran Dasar}

\subsubsection{Sinking Stream Kedungbuntung}

Sinking Stream Kedungbuntung merupakan sungai permukaan yang tertelan mulut gua (Gambar 4.1.a). Sungai ini tidak pernah kering sepanjang tahun sehingga disebut sebagai sungai perennial. Gambar 3.9 menunjukkan bahwa Mataair Kali Banteng, Beji, Mudal, dan Jebul menjadi suplai utama aliran air saat musim kemarau. Ketika terjadi hujan, sungai ini mendapat imbuhan limpasan permukaan dari lahan sekitarnya. Oleh karena itu, Sinking Stream Kedungbuntung memiliki debit yang lebih besar dan berwarna keruh ketika musim penghujan. Ketika musim kemarau, sungai ini memiliki debit yang lebih rendah dan berwarna jernih (Gambar 4.1).
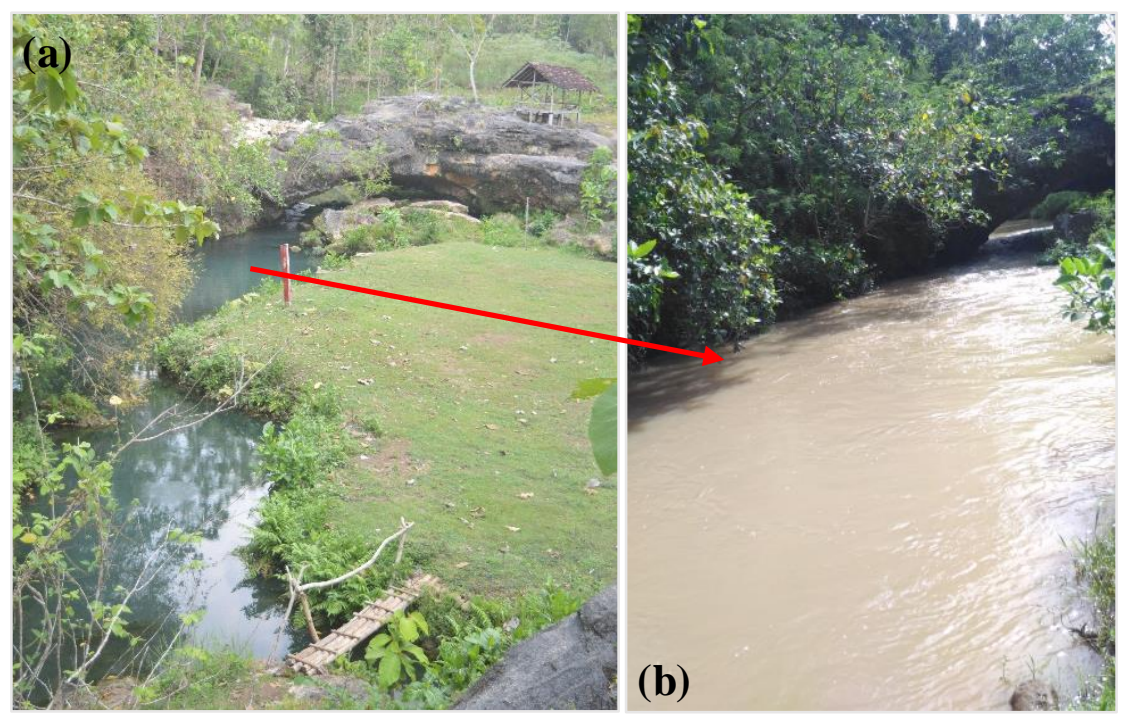

Gambar 4.1. Sinking Stream Kedungbuntung: (a) Kondisi saat musim kemarau, (b) Kondisi saat musim penghujan

\section{a. Rating Curve Sinking Stream Kedungbuntung}

Pengukuran debit di Sinking Stream Kedungbuntung dilakukan sebanyak 29 kali. Tabel 4.1 menunjukkan bahwa pengukuran sempat dilakukan ketika banjir terjadi, yaitu pada tanggal 5 Januari 2017 dengan debit puncak 5.320 liter/detik dan tanggal 3 Februari 2017 dengan debit puncak 6.100 liter/detik. Pengukuran debit 
terendah tercatat ketika hujan tidak sering terjadi lagi, yaitu pada tanggal $17 \mathrm{Mei}$ 2017 dengan debit 1.860 liter/detik.

Tabel 4.1. Hasil pengukuran debit aliran Sinking Stream Kedungbuntung

\begin{tabular}{llllllllll}
\hline No & Tanggal & Waktu & $\begin{array}{l}\text { TMA } \\
\text { (meter) }\end{array}$ & $\begin{array}{l}\text { Q } \\
\text { (lt/detik) }\end{array}$ & No & Tanggal & Waktu & $\begin{array}{l}\text { TMA } \\
\text { (meter) }\end{array}$ & $\begin{array}{l}\text { Q } \\
\text { (lt/detik) }\end{array}$ \\
\hline 1 & $5 / 1 / 2017$ & $18: 00$ & 1,78 & 5.320 & 16 & $3 / 2 / 2017$ & $7: 00$ & 1,49 & 3.866 \\
2 & $5 / 1 / 2017$ & $18: 30$ & 1,73 & 4.780 & 17 & $3 / 2 / 2017$ & $7: 30$ & 1,43 & 3.711 \\
3 & $5 / 1 / 2017$ & $19: 00$ & 1,52 & 3.440 & 18 & $3 / 2 / 2017$ & $8: 00$ & 1,36 & 3.150 \\
4 & $5 / 1 / 2017$ & $19: 30$ & 1,40 & 3.647 & 19 & $3 / 2 / 2017$ & $8: 30$ & 1,32 & 3.445 \\
5 & $5 / 1 / 2017$ & $20: 00$ & 1,34 & 2.980 & 20 & $3 / 2 / 2017$ & $9: 00$ & 1,28 & 3.620 \\
6 & $5 / 1 / 2017$ & $20: 30$ & 1,30 & 3.400 & 21 & $3 / 2 / 2017$ & $9: 30$ & 1,24 & 3.500 \\
7 & $5 / 1 / 2017$ & $21: 00$ & 1,25 & 3.600 & 22 & $3 / 2 / 2017$ & $10: 00$ & 1,21 & 3.181 \\
8 & $5 / 1 / 2017$ & $21: 30$ & 1,19 & 2.880 & 23 & $4 / 2 / 2017$ & $11: 30$ & 0,89 & 2.440 \\
9 & $5 / 1 / 2017$ & $22: 00$ & 1,16 & 2.910 & 24 & $7 / 2 / 2017$ & $13: 15$ & 0,76 & 2.130 \\
10 & $5 / 1 / 2017$ & $22: 30$ & 1,13 & 2.770 & 25 & $12 / 2 / 2017$ & $14: 00$ & 0,81 & 2.160 \\
11 & $3 / 2 / 2017$ & $4: 30$ & 2,21 & 6.100 & 26 & $26 / 2 / 2017$ & $12: 30$ & 0,75 & 1.980 \\
12 & $3 / 2 / 2017$ & $5: 00$ & 2,12 & 5.100 & 27 & $23 / 3 / 2017$ & $13: 45$ & 0,80 & 2.260 \\
13 & $3 / 2 / 2017$ & $5: 30$ & 1,98 & 4.960 & 28 & $20 / 4 / 2017$ & $14: 45$ & 0,74 & 2.010 \\
14 & $3 / 2 / 2017$ & $6: 00$ & 1,78 & 4.589 & 29 & $17 / 5 / 2017$ & $15: 30$ & 0,69 & 1.860 \\
15 & $3 / 2 / 2017$ & $6: 30$ & 1,60 & 4.139 & & & & & \\
\hline
\end{tabular}

Pengukuran debit aliran digunakan untuk membuat rating curve (Gambar 4.2). Debit aliran dan tinggi muka air (TMA) dari hasil pengukuran lapangan di Sinking Stream Kedunguntung memiliki hubungan yang erat. Hal ini ditunjukkan dengan $\mathrm{R}^{2}$ yang bernilai 0,95 . Hubungan tersebut memiliki persamaan sebagai berikut:

$$
\text { Debit }=2,6453 T M A^{0,95}
$$

Rumus diatas digunakan untuk menghitung debit aliran secara kontinu, yaitu menggunakan data TMA yang tercatat setiap 15 menit sekali pada alat logger muka air. Gambar 4.3 menunjukkan variasi debit aliran di Sinking Stream Kedungbuntung selama enam bulan.

\section{b. Konstanta Resesi Sinking Stream Kedungbuntung}

Sinking Stream Kedungbuntung memiliki sebelas kejadian banjir terpilih yang dapat dihitung konstanta resesinya. Pemilihan ini dilakukan pada hidrograf yang memiliki waktu resesi cukup panjang sehingga dapat dihitung konstanta resesi aliran conduit $\left(\mathrm{K}_{\mathrm{c}}\right)$, aliran fissure $\left(\mathrm{K}_{\mathrm{i}}\right)$, dan aliran diffuse $\left(\mathrm{K}_{\mathrm{b}}\right)$. Gambar 4.4.a dan b menunjukkan keadaan resesi dari sebelas kejadian banjir yang telah dipisahkan menjadi overlandflow (aliran conduit), interflow (aliran fissure), dan baseflow 
(aliran diffuse). Gambar tersebut menunjukkan bentuk yang bervariasi. Hal ini disebabkan oleh bervariasinya pelepasan masing-masing komponen oleh sistem drainase karst. Menurut Schulz (1976), pelepasan suatu komponen yang cepat akan memiliki nilai konstanta resesi yang lebih kecil dan memiliki bentuk grafik yang curam.

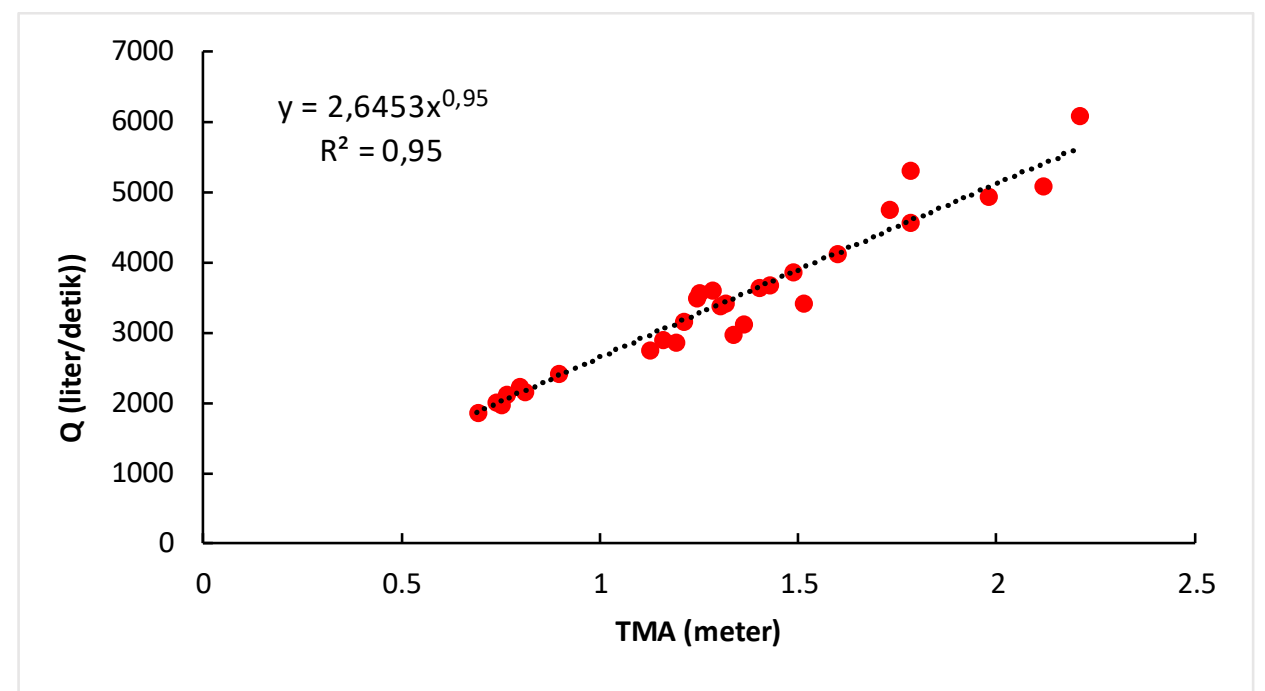

Gambar 4.2. Rating curve Sinking Stream Kedungbuntung

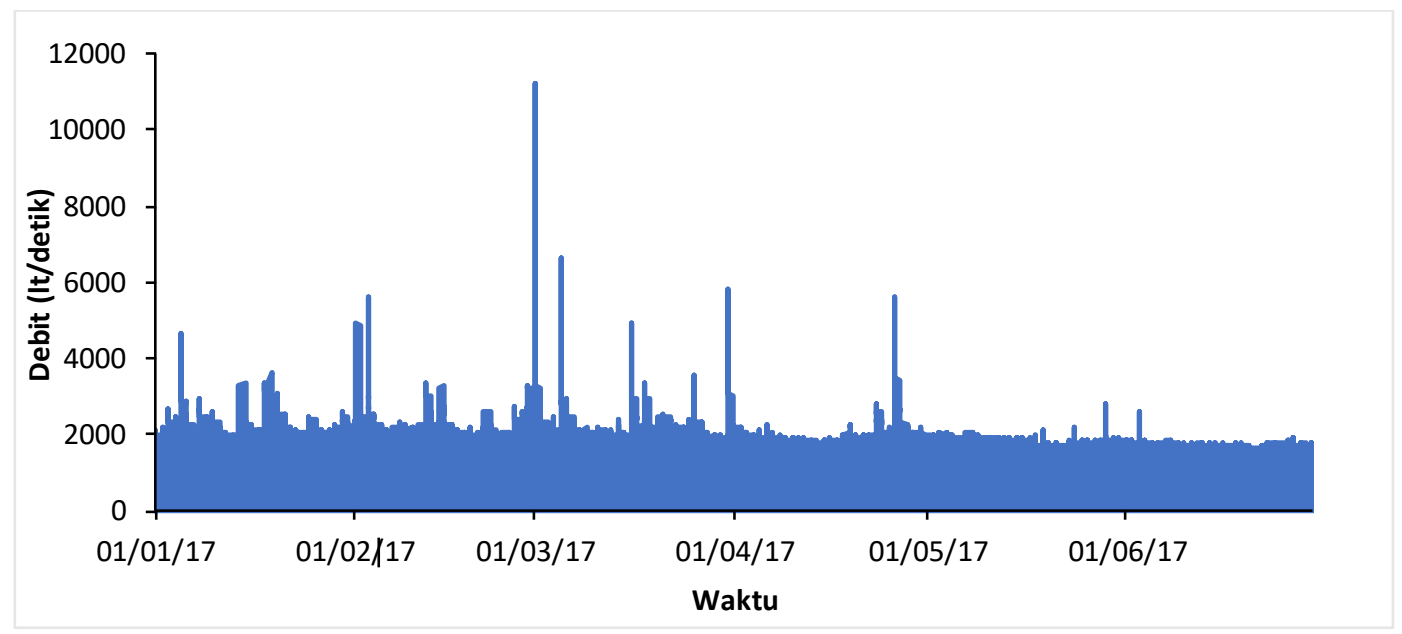

Gambar 4.3. Hidrograf aliran Sinking Stream Kedungbuntung selama kurun waktu 1 Januari-30 Juni 2017

Variasi nilai konstanta resesi dari sebelas kejadian banjir terpilih dapat dilihat pada Tabel 4.2. Ketiga komponen aliran (conduit, fissure, dan diffuse) memiliki konstanta yang bervariasi. Nilai $\mathrm{K}_{\mathrm{b}}$ memiliki julat 0,966-0,998 dengan rerata 0,990 . Nilai $K_{i}$ memiliki julat 0,558-0,890 dengan rerata 0,760. Nilai $K_{b}$ dan 
$\mathrm{K}_{\mathrm{i}}$ yang kecil terjadi ketika banjir memunyai debit puncak $\left(\mathrm{Q}_{\mathrm{p}}\right)$ yang besar, yaitu pada 1 Maret $2017\left(\mathrm{Q}_{\mathrm{p}}=11.215\right.$ liter/detik; $\left.\mathrm{K}_{\mathrm{b}}=0,966 ; \mathrm{K}_{\mathrm{i}}=0,558\right)$ dan pada 5 Maret $2017\left(\mathrm{Q}_{\mathrm{p}}=6.644\right.$ liter/detik; $\left.\mathrm{K}_{\mathrm{b}}=0,982 ; \mathrm{K}_{\mathrm{i}}=0,655\right)$.

Tabel 4.2. Konstanta resesi, $\mathrm{T}_{\mathrm{p}}, \mathrm{T}_{\mathrm{b}}$, dan $\mathrm{Q}_{\mathrm{p}}$ dari hidrograf banjir terpilih Sinking Stream Kedungbuntung

\begin{tabular}{llllllll}
\hline No & Tanggal & $\begin{array}{l}\mathrm{Qp}_{\mathrm{p}} \\
(\mathrm{lt} / \mathrm{detik})\end{array}$ & $\begin{array}{l}\mathrm{K}_{\mathrm{r}} \\
\text { Diffuse } \\
\left(\mathrm{K}_{\mathrm{b}}\right)\end{array}$ & $\begin{array}{l}\mathrm{K}_{\mathrm{r}} \\
\text { Fissure } \\
\left(\mathrm{K}_{\mathrm{i}}\right)\end{array}$ & $\begin{array}{l}\mathrm{K}_{\mathrm{r}} \\
\text { Conduit } \\
\left(\mathrm{K}_{\mathrm{c}}\right)\end{array}$ & $\begin{array}{l}\mathrm{T}_{\mathrm{p}} \\
\text { (jam) }\end{array}$ & $\begin{array}{l}\mathrm{Tb} \\
\text { (jam) }\end{array}$ \\
\hline 1 & $5 / 1 / 2017$ & 4.626 & 0,993 & 0,710 & 0,327 & 2,5 & 13 \\
2 & $14 / 1 / 2017$ & 3.341 & 0,995 & 0,759 & 0,389 & 2,25 & 11 \\
3 & $1 / 2 / 2017$ & 4.934 & 0,990 & 0,728 & 0,262 & 6 & 18 \\
4 & $3 / 2 / 2017$ & 5.617 & 0,992 & 0,706 & 0,439 & 1,75 & 15 \\
5 & $14 / 2 / 2017$ & 3.289 & 0,993 & 0,820 & 0,246 & 2,5 & 19 \\
6 & $1 / 3 / 2017$ & 11.215 & 0,966 & 0,558 & 0,342 & 1,5 & 10 \\
7 & $5 / 3 / 2017$ & 6.644 & 0,982 & 0,655 & 0,292 & 1,25 & 11 \\
8 & $16 / 3 / 2017$ & 4.899 & 0,990 & 0,820 & 0,302 & 1,5 & 12 \\
9 & $25 / 3 / 2017$ & 3.532 & 0,998 & 0,825 & 0,431 & 5 & 16 \\
10 & $31 / 3 / 2017$ & 5.796 & 0,989 & 0,890 & 0,274 & 1,75 & 16 \\
11 & $26 / 4 / 2017$ & 5.614 & 0,993 & 0,888 & 0,275 & 2,25 & 11 \\
\hline \multicolumn{2}{l}{ Rata-Rata } & & 0,99 & 0,76 & 0,33 & 2,6 & 13,8 \\
\multicolumn{2}{l}{ Max } & & 0,998 & 0,89 & 0,439 & 6 & 19 \\
\multicolumn{2}{l}{ Min } & & 0,966 & 0,558 & 0,246 & 1,25 & 10 \\
\hline
\end{tabular}

Nilai $K_{c}$ memiliki julat 0,325-0,439 dengan rerata 0,325. Nilai $K_{c}$ yang kurang dari 0,5 menunjukkan pelepasan komponen aliran permukaan yang cepat (Schulz, 1976; Adji, 2009; Oktama, 2014; Bahtiar 2014). Sinking Stream Kedungbuntung merupakan sungai permukaan sehingga overlandflow (aliran conduit) akan dengan cepat dilepaskan. Overlandflow dari daerah tangkapan air akan mengimbuh saluran sungai yang kemudian akan langsung dilepaskan.

Parameter hidrograf yang berhubungan dengan kejadian resesi adalah $\mathrm{T}_{\mathrm{p}}$ dan $\mathrm{T}_{\mathrm{b}} . \mathrm{T}_{\mathrm{p}}$ memiliki julat antara 1,25-6 jam dengan rerata 2,6 jam. $\mathrm{T}_{\mathrm{b}}$ memiliki julat antara 10-19 jam dengan rerata 13,8 jam. Pembahasan mendetail mengenai keadaan resesi ini akan dibahas pada Subbab 4.1.3.

\section{c. Prosentase Aliran Dasar Sinking Stream Kedungbuntung}

Prosentase aliran dasar didapatkan dengan memisahkan alian conduit dan fissure dengan diffuse. Sinking Stream Kedungbuntung memiliki rasio aliran dasar yang dominan. Gambar 4.5 menunjukkan aliran diffuse memiliki luas area yang lebih besar dibandingkan aliran conduit dan fissure. Dominasi ini juga dibuktikan 
dengan kecilnya fluktuasi nilai PAD ketika musim penghujan dan kemarau (Tabel 4.3). PAD bulanan ini memiliki julat 95,34-99,39\% pada kedua musim. Dominasi aliran dasar pada Kedungbuntung menunjukkan bahwa daerah tangkapan air memiliki dominasi retakan diffuse yang mampu menyimpan air dan melepaskannya perlahan-lahan.
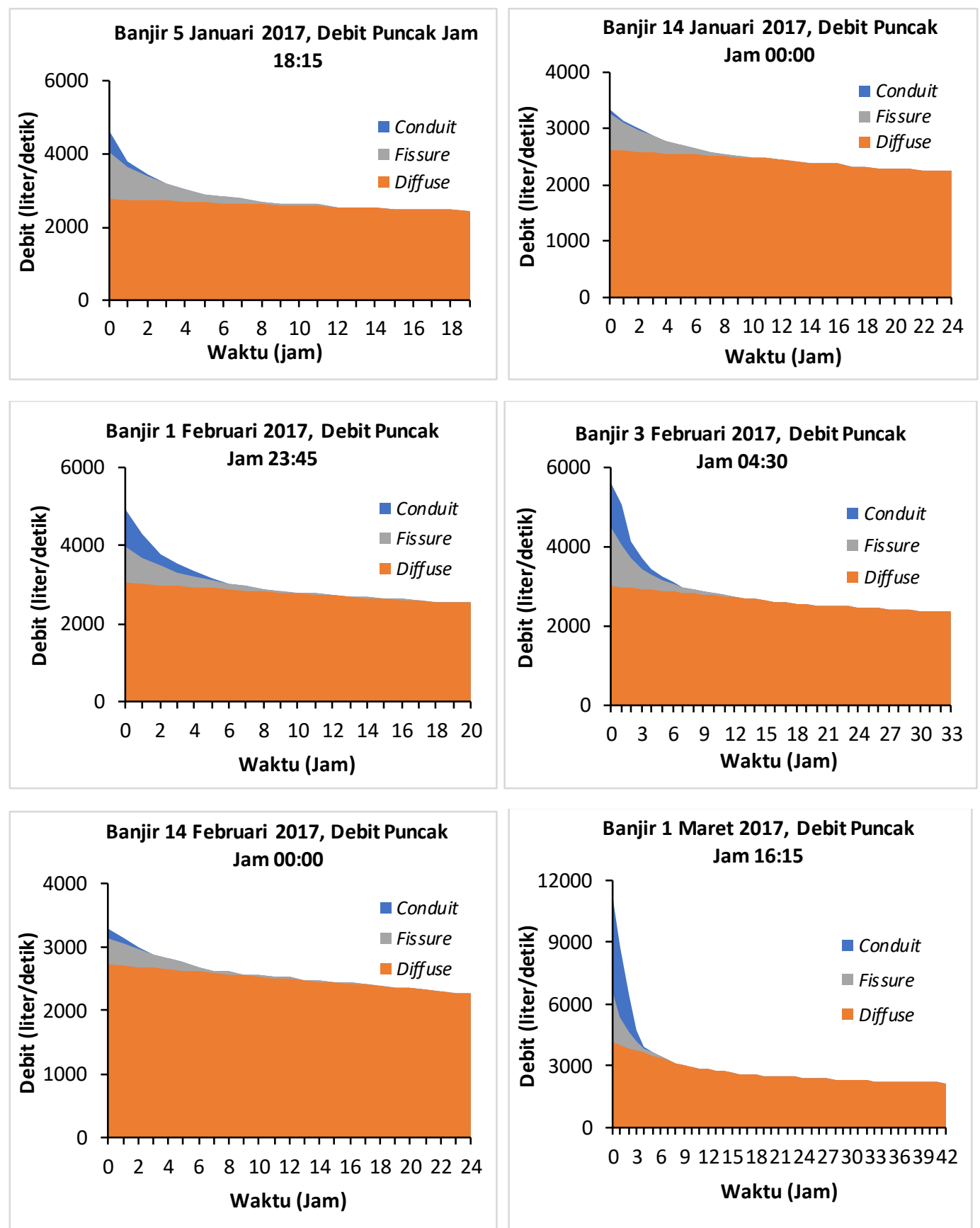

Gambar 4.4.a. Kejadian resesi banjir-banjir terpilih Sinking Stream Kedungbuntung 

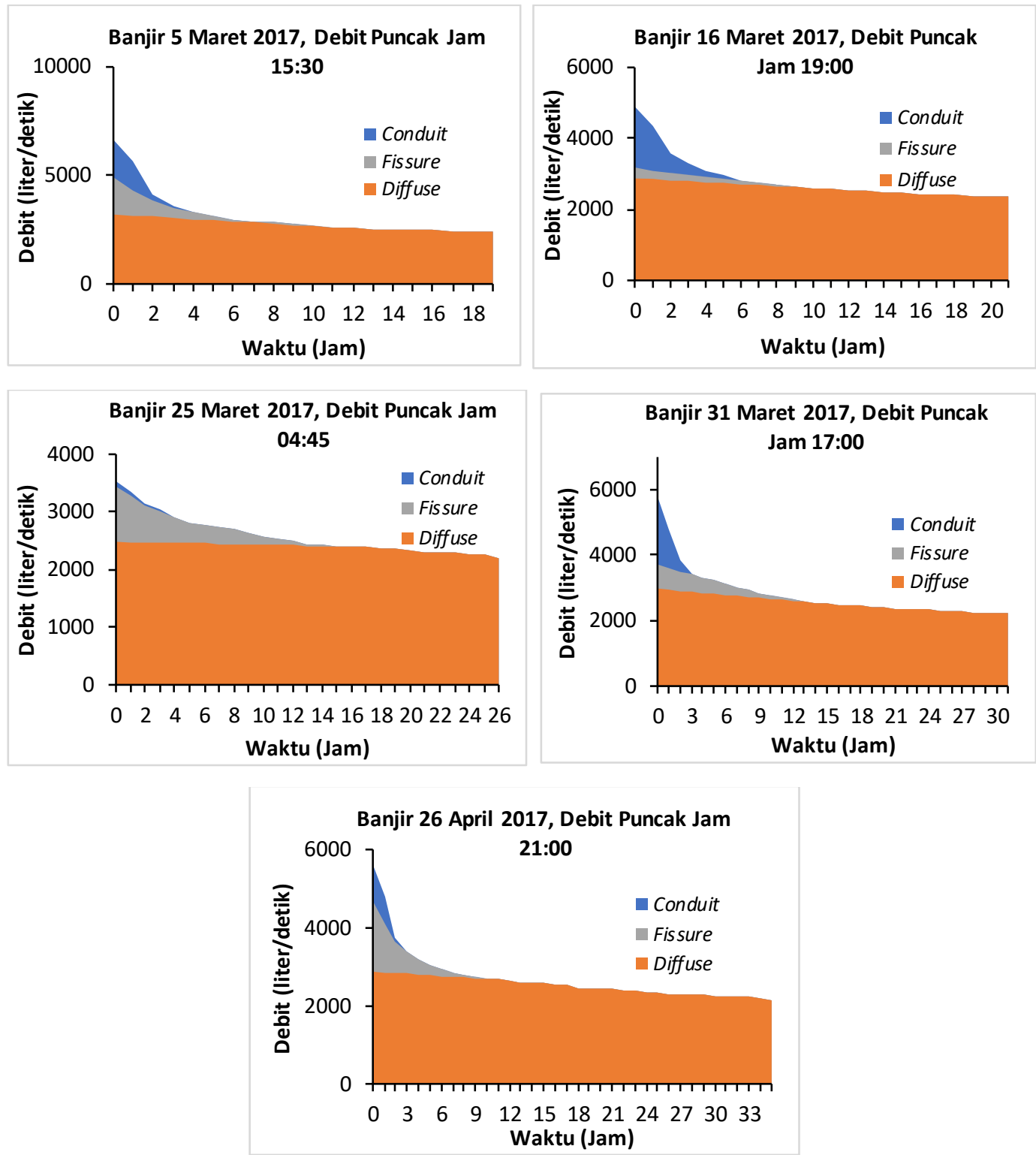

Gambar 4.4.b. Kejadian resesi banjir-banjir terpilih Sinking Stream Kedungbuntung

Prosentase aliran dasar pada musim penghujan yang lebih kecil dibandingkan musim kemarau disebabkan oleh adanya kejadian banjir yang didominasi oleh aliran conduit (Tabel 4.3). Tabel 4.4 menunjukkan PAD pada kejadian banjir. PAD setiap kejadian banjir Kedungbuntung memiliki julat 24,26$72,23 \%$ dengan rerata $47,21 \%$. PAD terkecil terjadi ketika banjir dengan debit puncak $\left(\mathrm{Q}_{\mathrm{p}}\right.$ ) besar (aliran conduit besar) terjadi, yaitu pada tanggal 1 Maret 2017 dengan $Q_{p} 11.215$ lt/detik dan PAD 24,26\%. 


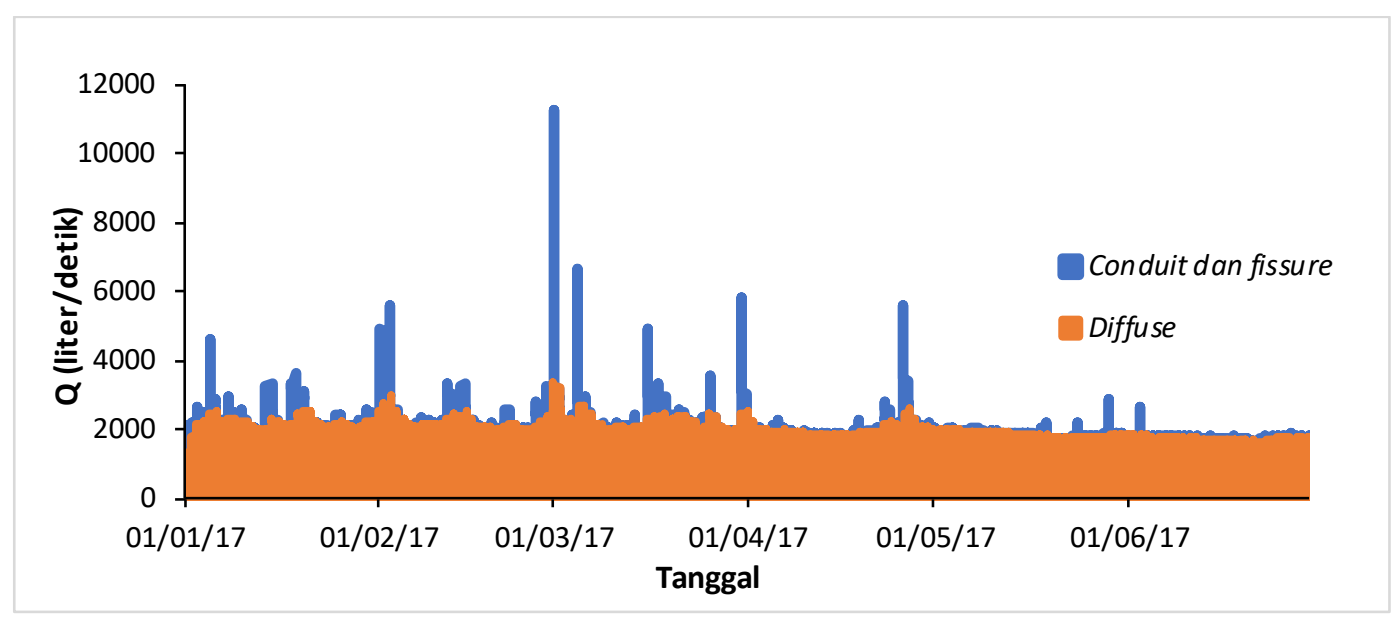

Gambar 4.5. Fluktuasi aliran dasar Sinking Stream Kedungbuntung selama kurun waktu 1 Januari 2017-30 Juni 2017

Tabel 4.3. Fluktasi PAD bulanan Sinking Stream Kedungbuntung

\begin{tabular}{llll}
\hline No & Bulan & PAD $(\%)$ & Musim \\
\hline 1 & Januari & 96,88 & awal hujan \\
2 & Februari & 96,60 & awal hujan \\
3 & Maret & 95,34 & akhir hujan \\
4 & April & 97,61 & akhir hujan \\
5 & Mei & 99,45 & awal kemarau \\
6 & Juni & 99,39 & awal kemarau \\
\hline
\end{tabular}

Tabel 4.4. PAD setiap kejadian banjir di Sinking Stream Kedungbuntung

\begin{tabular}{lllll}
\hline No & Tanggal & $\begin{array}{l}\text { Qp } \\
\text { (lt/detik) }\end{array}$ & $\begin{array}{l}\text { Qb } \\
\text { (lt/detik) }\end{array}$ & $\begin{array}{l}\text { PAD } \\
(\%)\end{array}$ \\
\hline 1 & $5 / 1 / 2017$ & 4.626 & 2.227 & 48,15 \\
2 & $14 / 1 / 2017$ & 3.341 & 2.028 & 60,69 \\
3 & $1 / 2 / 2017$ & 4.934 & 2.511 & 50,89 \\
4 & $3 / 2 / 2017$ & 5.617 & 2.746 & 48,9 \\
5 & $14 / 2 / 2017$ & 3.289 & 2.375 & 72,23 \\
6 & $1 / 3 / 2017$ & 11.215 & 2.721 & 24,26 \\
7 & $5 / 3 / 2017$ & 6.644 & 2.241 & 33,73 \\
8 & $16 / 3 / 2017$ & 4.899 & 2.011 & 41,05 \\
9 & $25 / 3 / 2017$ & 3.532 & 2.252 & 63,76 \\
10 & $31 / 3 / 2017$ & 5.796 & 2.062 & 35,57 \\
11 & $26 / 4 / 2017$ & 5.614 & 2.250 & 40,07 \\
\hline Rata-Rata & & & 47,21 \\
Max & & & & 72,23 \\
Min & & & & 24,26 \\
\hline
\end{tabular}

Dominasi aliran conduit pada setiap kejadian banjir disebabkan oleh karakteristik Sinking Stream Kedungbuntung yang berupa sungai permukaan. Hal tersebut menyebabkan overlandflow (aliran conduit) dan interflow (aliran fissure) langsung mengimbuh saluran sungai. Selain itu, DTA Kedungbuntung yang didominasi retakan diffuse tetap memiliki retakan conduit. Atkinson (1985) 
menyatakan bahwa sifat aliran pada sistem karst tidak pernah mendominasi secara tunggal (Gambar 1.7). Gambar 4.7 menunjukkan adanya retakan conduit yang mengimbuh Mataair Mudal di DTA Kedungbuntung. Retakan conduit menyebabkan mataair menjadi keruh ketika hujan.
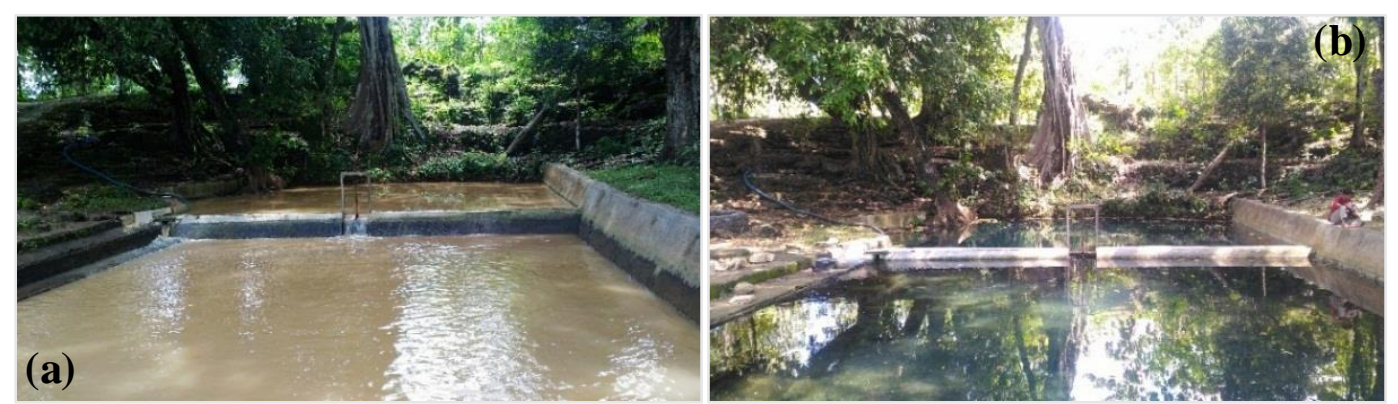

Gambar 4.6. Mataair Mudal: (a) Kondisi setelah hujan,

(b) Kondisi tidak ada hujan

\subsubsection{Gua Pindul}

Gua Pindul merupakan outlet dari daerah tangkapan air (DTA) Sistem Karst Pindul (Agniy, 2016). Air pada Gua Pindul tidak pernah kering sepanjang musim dan berwarna keruh ketika terjadi hujan (Gambar 4.7). Ketika musim kemarau, gua ini mendapat suplai air dari sistem perguaan yang saling terhubung (Gua Asri, Gua Greng, Gua Emas, Gua Candi, Gua Suruh, dan Gua Sioyot) dan Sinking Stream Kedungbuntung (Haryono, 2014; Agniy, 2016). Adanya sistem perguaan dan sinking stream tersebut menjadikan dominannya aliran conduit ketika terjadi hujan. Hal ini menyebabkan keruhnya air di Gua Pindul.

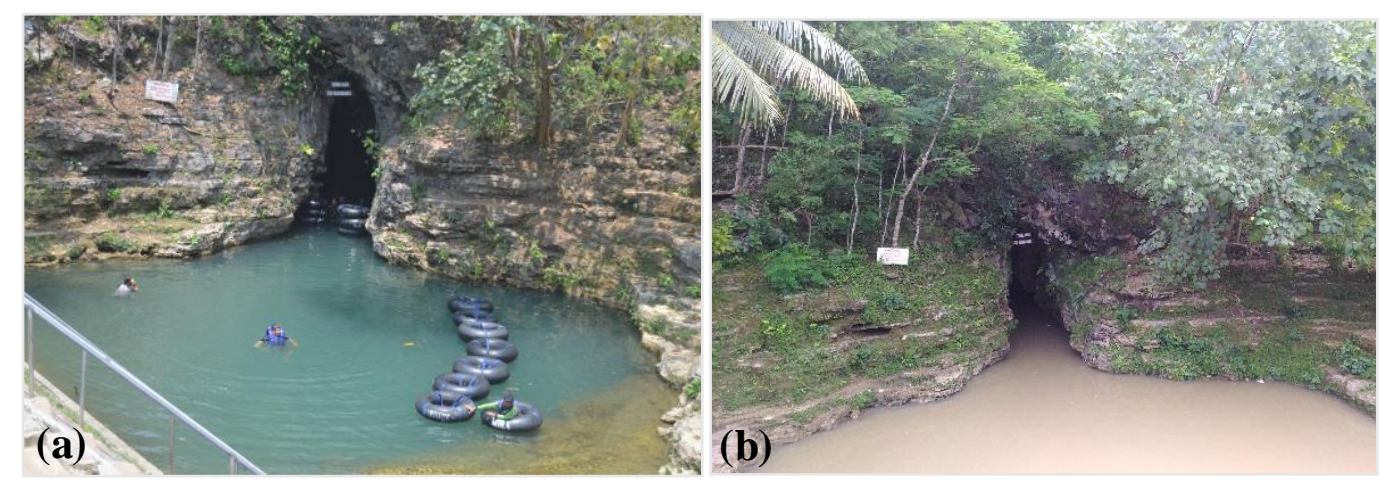

Gambar 4.7. Gua Pindul: (a) Kondisi musim kemarau, (b) Kondisi musim penghujan

\section{a. Rating Curve Gua Pindul}

Pengukuran debit aliran di Gua Pindul dilakukan sebanyak 29 kali. Tabel 4.5 menunjukkan pengukuran debit sempat dilakukan ketika banjir terjadi, yaitu 
pengukuran pada tanggal 5 Januari dengan debit puncak 9.970 liter/detik dan pengukuran pada tanggal 3 Februari 2017 dengan debit puncak 13.050 liter/detik. Debit aliran terendah terjadi pada pengukuran tanggal 17 Mei 2017 dengan nilai 3.523 liter/detik.

Tabel 4.5. Hasil pengukuran debit aliran Gua Pindul

\begin{tabular}{llllllllllll}
\hline \multirow{2}{*}{ No } & Tanggal & Waktu & $\begin{array}{l}\text { TMA } \\
\text { (meter) }\end{array}$ & $\begin{array}{l}\text { Q } \\
\text { (lt/detik) }\end{array}$ & & No & Tanggal & Waktu & $\begin{array}{l}\text { TMA } \\
\text { (meter) }\end{array}$ & $\begin{array}{l}\text { Q } \\
\text { (lt/detik) }\end{array}$ \\
\hline 1 & $5 / 1 / 2017$ & $18: 00$ & 5,63 & 9.970 & & 16 & $3 / 2 / 2017$ & $7: 00$ & 5,35 & 8.250 \\
2 & $5 / 1 / 2017$ & $18: 30$ & 5,63 & 9.730 & & 17 & $3 / 2 / 2017$ & $7: 30$ & 5,25 & 8.006 \\
3 & $5 / 1 / 2017$ & $19: 00$ & 5,48 & 8.700 & & 18 & $3 / 2 / 2017$ & $8: 00$ & 5,15 & 5.400 \\
4 & $5 / 1 / 2017$ & $19: 30$ & 5,35 & 8.625 & & 19 & $3 / 2 / 2017$ & $8: 30$ & 5,08 & 5.350 \\
5 & $5 / 1 / 2017$ & $20: 00$ & 5,22 & 7.874 & & 20 & $3 / 2 / 2017$ & $9: 00$ & 5,02 & 6.695 \\
6 & $5 / 1 / 2017$ & $20: 30$ & 5,12 & 6.770 & & 21 & $3 / 2 / 2017$ & $9: 30$ & 4,97 & 6.403 \\
7 & $5 / 1 / 2017$ & $21: 00$ & 5,04 & 6.400 & & 22 & $3 / 2 / 2017$ & $10: 00$ & 4,92 & 6.156 \\
8 & $5 / 1 / 2017$ & $21: 30$ & 4,95 & 6.334 & & 23 & $4 / 2 / 2017$ & $12: 30$ & 4,53 & 3.898 \\
9 & $5 / 1 / 2017$ & $22: 00$ & 4,90 & 5.450 & & 24 & $7 / 2 / 2017$ & $13: 00$ & 4,47 & 3.609 \\
10 & $5 / 1 / 2017$ & $22: 30$ & 4,85 & 5.750 & & 25 & $12 / 2 / 2017$ & $13: 24$ & 4,49 & 3.653 \\
11 & $3 / 2 / 2017$ & $4: 30$ & 5,97 & 13.050 & & 26 & $26 / 2 / 2017$ & $12: 15$ & 4,47 & 3.609 \\
12 & $3 / 2 / 2017$ & $5: 00$ & 5,92 & 11.050 & & 27 & $23 / 3 / 2017$ & $13: 30$ & 4,48 & 3.653 \\
13 & $3 / 2 / 2017$ & $5: 30$ & 5,83 & 11.334 & & 28 & $20 / 4 / 2017$ & $16: 00$ & 4,45 & 3.674 \\
14 & $3 / 2 / 2017$ & $6: 00$ & 5,67 & 10.412 & & 29 & $17 / 5 / 2017$ & $14: 30$ & 4,47 & 3.523 \\
15 & $3 / 2 / 2017$ & $6: 30$ & 5,50 & 9.438 & & & & & & \\
\hline
\end{tabular}

Rating curve Gua Pindul didapatkan dari pengukuran debit aliran yang telah dijelaskan di atas (Gambar 4.8). Hubungan debit dengan TMA memiliki keeratan yang signifikan, yaitu ditunjukkan dengan nilai $\mathrm{R}^{2}$ sebesar 0,96 . Hubungan tersebut memiliki persamaan sebagai berikut:

$$
\text { Debit }=6,0077 T M A^{4,3}
$$

Debit aliran yang kontinu selama enam bulan (1 Januari 2017-30 Juni 2017) diperoleh melalui persamaan diatas. Gambar 4.9 menunjukkan beberapa kali banjir terjadi pada bulan Januari-April. Nilai debit terbesar didapatkan pada banjir tanggal 1 Maret 2017 dengan nilai 30.681 liter/detik.

\section{b. Konstanta Resesi Gua Pindul}

Gua Pindul memiliki sebelas kejadian banjir yang dapat dihitung nilai konstanta resesinya. Gambar 4.10.a dan b menunjukkan variasi resesi dari sebelas kejadian banjir terpilih. Nilai konstanta resesi yang kecil memiliki bentuk grafik yang curam (Schulz, 1976). Gua Pindul memiliki variasi yang tinggi dalam melepaskan setiap komponen alirannya (Tabel 4.6). Nilai $\mathrm{K}_{\mathrm{b}}$ Gua Pindul memiliki 
julat 0,960-0,994 dengan rerata 0,980. Nilai $\mathrm{K}_{\mathrm{i}}$ memiliki julat 0,596-0,848 dengan rerata 0,710. Nilai $K_{c}$ memiliki julat 0,155-0,544 dengan rerata 0,3. Nilai $T_{p}$ dan $T_{b}$ Gua Pindul juga memiliki variasi yang besar. Nilai $T_{p}$ memiliki julat 1,5-6 jam dengan rerata 2,7 jam. Nilai $\mathrm{T}_{\mathrm{b}}$ memiliki julat 10-20 jam dengan rerata 13,4 jam

Tabel 4.6. Konstanta Resesi, $\mathrm{T}_{\mathrm{p}}, \mathrm{T}_{\mathrm{b}}$, dan $\mathrm{Q}_{\mathrm{p}}$ Hidrograf Banjir Terpilih

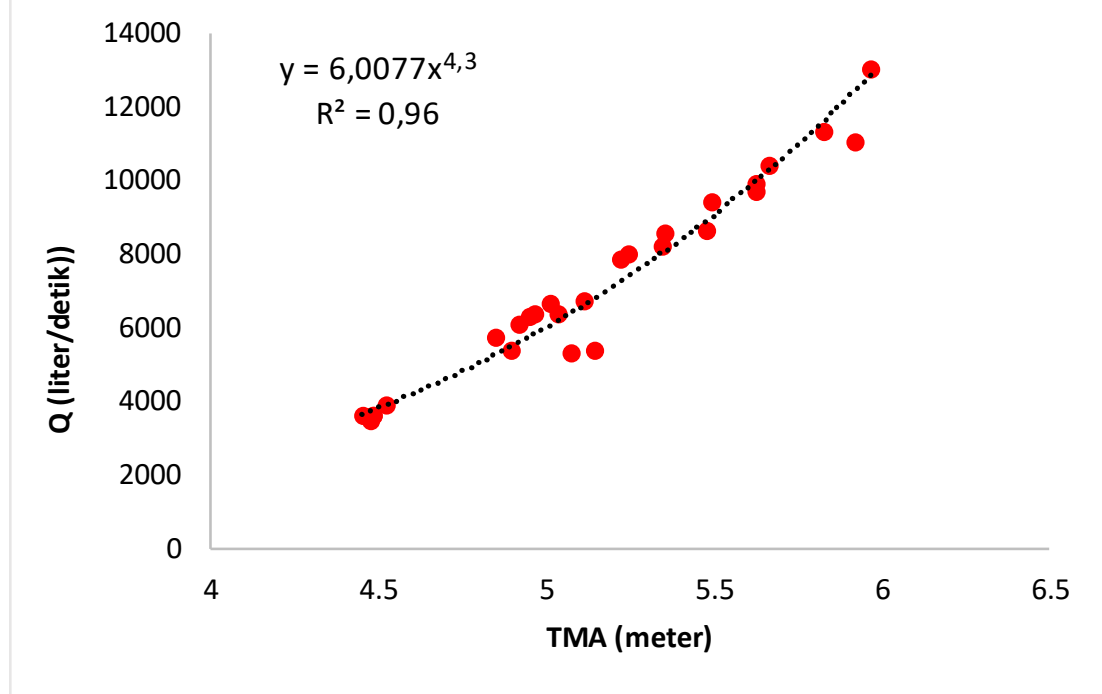

Gambar 4.8. Rating curve Gua Pindul

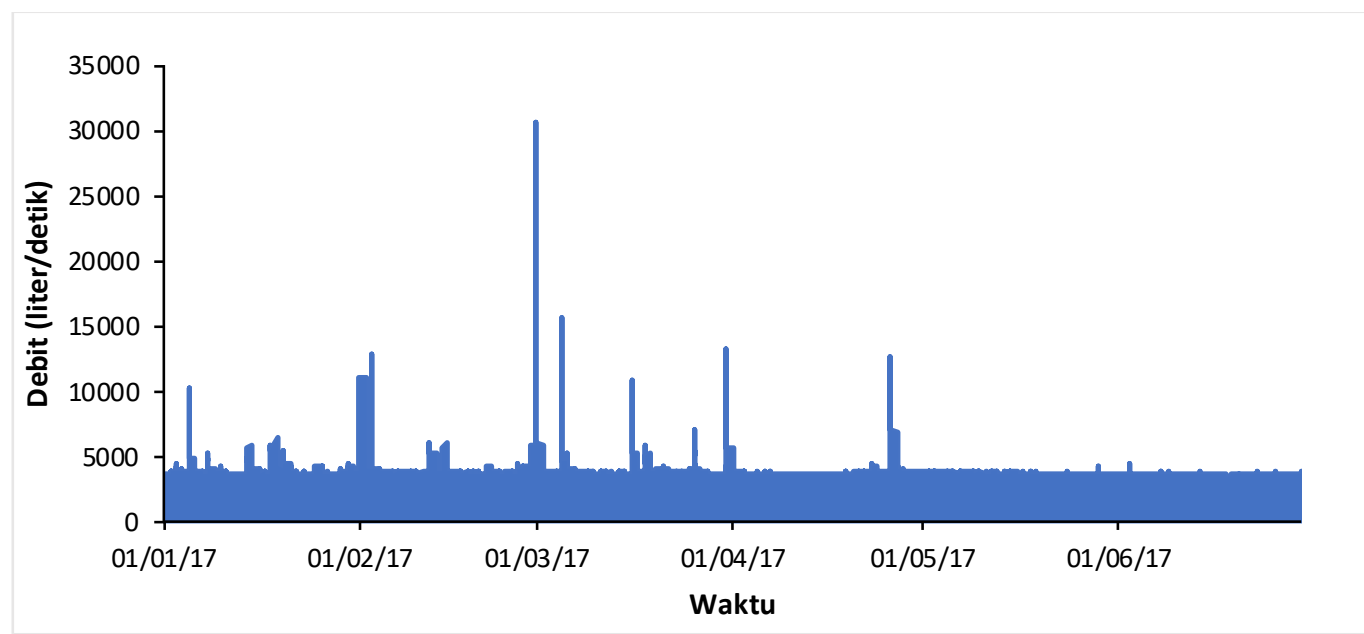

Gambar 4.9. Hidrograf aliran Gua Pindul selama kurun waktu 1 Januari 2017-30 Juni 2017

Nilai $K_{b}$ dan $K_{i}$ memiliki nilai yang kecil ketika banjir besar terjadi. Banjir besar pada tanggal 1 Maret 2017 memiliki debit puncak $\left(\mathrm{Q}_{\mathrm{p}}\right)$ bernilai 30.681 liter/detik serta nilai $\mathrm{Kb}$ dan Ki sebesar 0,961 dan 0,627. Banjir besar kedua terjadi pada tanggal 5 Maret 2017 yang memiliki Qp dengan nilai 15.666 liter/detik serta $\mathrm{K}_{\mathrm{b}}$ dan $\mathrm{K}_{\mathrm{i}}$ dengan nilai 0,981 dan 0,596. 
Tabel 4.6. Konstanta resesi, $\mathrm{T}_{\mathrm{p}}, \mathrm{T}_{\mathrm{b}}$, dan $\mathrm{Q}_{\mathrm{p}}$ dari hidrograf banjir terpilih di Gua Pindul

\begin{tabular}{llllllll}
\hline No & Tanggal & $\begin{array}{l}\mathrm{Qp} \\
\text { (lt/detik) }\end{array}$ & $\begin{array}{l}\mathrm{Kr} \\
\text { Diffuse } \\
(\mathrm{Kb})\end{array}$ & $\begin{array}{l}\mathrm{K}_{\mathrm{r}} \\
\text { Fissure } \\
\left(\mathrm{K}_{\mathrm{i}}\right)\end{array}$ & $\begin{array}{l}\mathrm{Kr}_{\text {Conduit }} \\
\left(\mathrm{K}_{\mathrm{c}}\right)\end{array}$ & $\begin{array}{l}\mathrm{T}_{\mathrm{p}} \\
\text { (jam) }\end{array}$ & $\begin{array}{l}\mathrm{Tb} \\
\text { (jam) }\end{array}$ \\
\hline 1 & $5 / 1 / 2017$ & 10.320 & 0,994 & 0,681 & 0,289 & 2,5 & 15 \\
2 & $14 / 1 / 2017$ & 5.874 & 0,994 & 0,848 & 0,370 & 2,25 & 18 \\
3 & $1 / 2 / 2017$ & 11.132 & 0,992 & 0,743 & 0,288 & 6 & 14 \\
4 & $3 / 2 / 2017$ & 5.617 & 0,991 & 0,673 & 0,155 & 1,75 & 20 \\
5 & $14 / 2 / 2017$ & 6.019 & 0,993 & 0,730 & 0,544 & 2,75 & 12 \\
6 & $1 / 3 / 2017$ & 30.681 & 0,961 & 0,627 & 0,190 & 1,5 & 11 \\
7 & $5 / 3 / 2017$ & 15.666 & 0,981 & 0,596 & 0,159 & 1,5 & 11 \\
8 & $16 / 3 / 2017$ & 10.886 & 0,990 & 0,650 & 0,303 & 1,75 & 12 \\
9 & $25 / 3 / 2017$ & 5.395 & 0,980 & 0,786 & 0,353 & 5,25 & 10 \\
10 & $31 / 3 / 2017$ & 13.213 & 0,960 & 0,773 & 0,301 & 1,75 & 11 \\
11 & $26 / 4 / 2017$ & 12.647 & 0,992 & 0,652 & 0,381 & 2,25 & 13 \\
\hline \multicolumn{2}{l}{ Rata-Rata } & & 0,98 & 0,71 & 0,30 & 2,7 & 13,4 \\
\multicolumn{2}{l}{ Max } & & 0,994 & 0,848 & 0,544 & 6 & 20 \\
\multicolumn{2}{l}{ Min } & & 0,96 & 0,596 & 0,155 & 1,5 & 10 \\
\hline
\end{tabular}

\section{c. Prosentase Aliran Dasar Gua Pindul}

Secara umum, Gua Pindul memiliki dominasi aliran dasar (Gambar 4.11). Sementara itu, aliran conduit dan fissure mendominasi pada banjir-banjir besar yang ditunjukkan dengan nilai debit puncak yang tinggi. Banjir besar di Gua Pindul disebabkan karena adanya imbuhan dari sistem perguaan dan sinking stream. Sinking stream merupakan sungai permukaan yang tertelan oleh gua sehingga tetap memiliki karakteristik respons cepat terhadap hujan. Sementara itu, sungai bawah tanah di sistem perguaan pada dasarnya memiliki karakteristik yang identik dengan sungai permukaan.

Adanya beberapa kali kejadian banjir menyebabkan prosentase aliran dasar (PAD) ketika musim penghujan lebih kecil dibandingkan ketika musim kemarau (Tabel 4.7). Meskipun demikian, fluktuasi PAD pada kedua musim tergolong kecil. PAD bulanana Gua Pindul memiliki julat 95,18-99,85\% pada kedua musim.

Hal diatas menunjukkan bahwa sistem perguaan dan sinking stream yang mensuplai air Gua Pindul masih dapat menyimpan air dan melepaskannya perlahanlahan. Adanya aliran air di sistem perguaan dan Sinking Stream Kedungbuntung 
ketika musim kemarau membuktikan hal tersebut. Ketika musim kemarau, Gua Greng memiliki debit sebesar 360 lt/dt, Gua Sioyot memiliki debit sebesar 390 lt/dt, Gua Suruh memiliki debit sebesar 130 lt/dt, dan Sinking Stream Kedungbuntung memiliki debit sebesar 1580 lt/dt (Agniy, 2016).
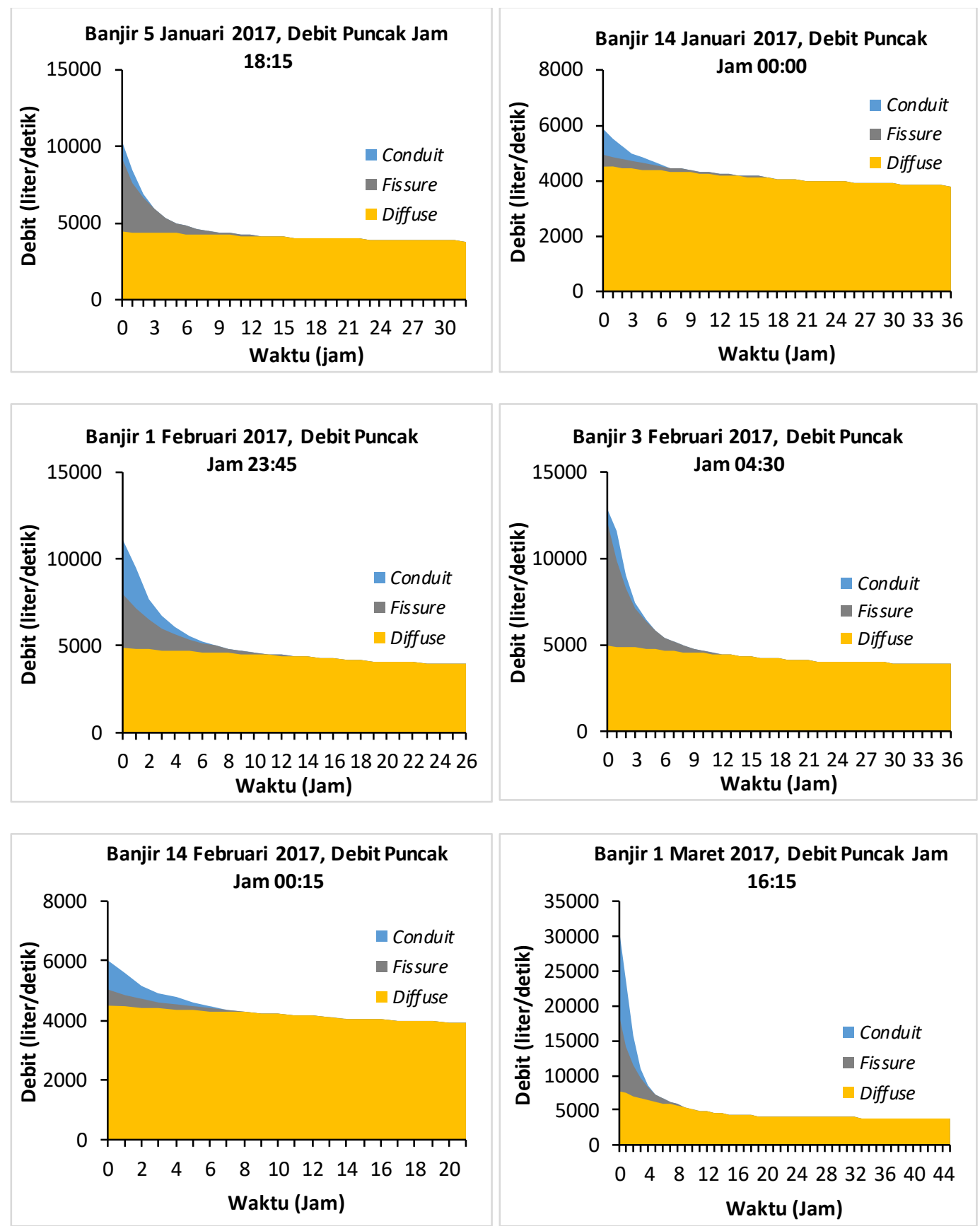

Gambar 4.10.a. Kejadian resesi banjir-banjir terpilih Gua Pindul

Dominasi aliran conduit di Gua Pindul ditunjukkan oleh PAD setiap kejadian banjir (Tabel 4.8). Aliran conduit menyebabkan PAD setiap kejadian 
banjir lebih kecil dibandingkan PAD musim kemarau. PAD setiap kejadian banjir memiliki julat 17,97-68,85\% dengan rerata 42,9\%. PAD terkecil disebabkan oleh adanya aliran conduit yang sangat dominan $\left(\mathrm{Q}_{\mathrm{p}}\right.$ yang besar), yaitu ditunjukkan oleh kejadian banjir pada tanggal 1 Maret 2017 dengan $Q_{p} 30.681$ liter/detik dan PAD $17,97 \%$.
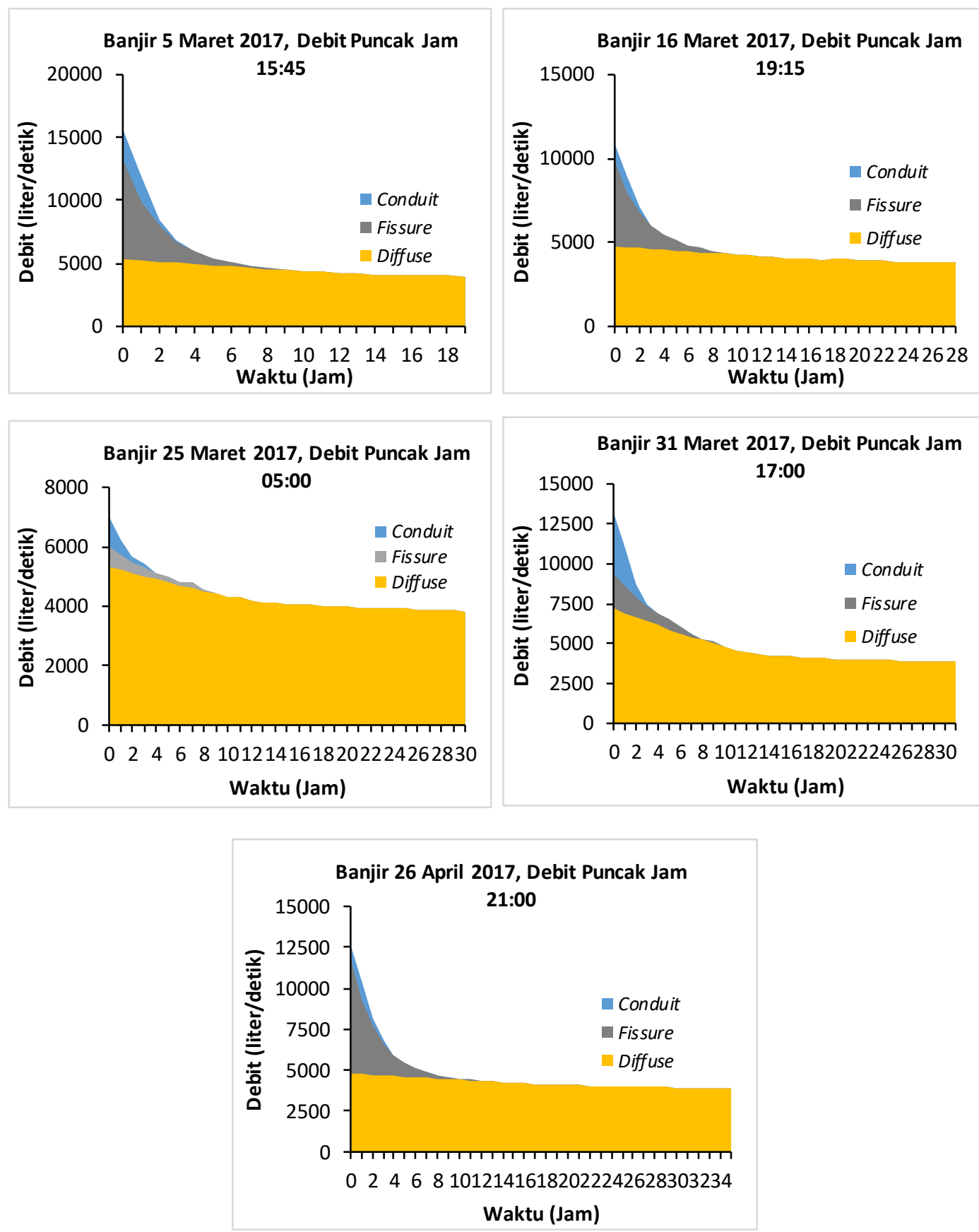

Gambar 4.10.b. Kejadian resesi banjir-banjir terpilih Gua Pindul 
Tabel 4.7. Fluktuasi PAD bulanan Gua Pindul

\begin{tabular}{llll}
\hline No & Bulan & PAD $(\%)$ & Musim \\
\hline 1 & Januari & 97,85 & awal hujan \\
2 & Februari & 97,34 & awal hujan \\
3 & Maret & 95,18 & akhir hujan \\
4 & April & 98,90 & akhir hujan \\
5 & Mei & 99,85 & awal kemarau \\
6 & Juni & 99,82 & awal kemarau \\
\hline
\end{tabular}

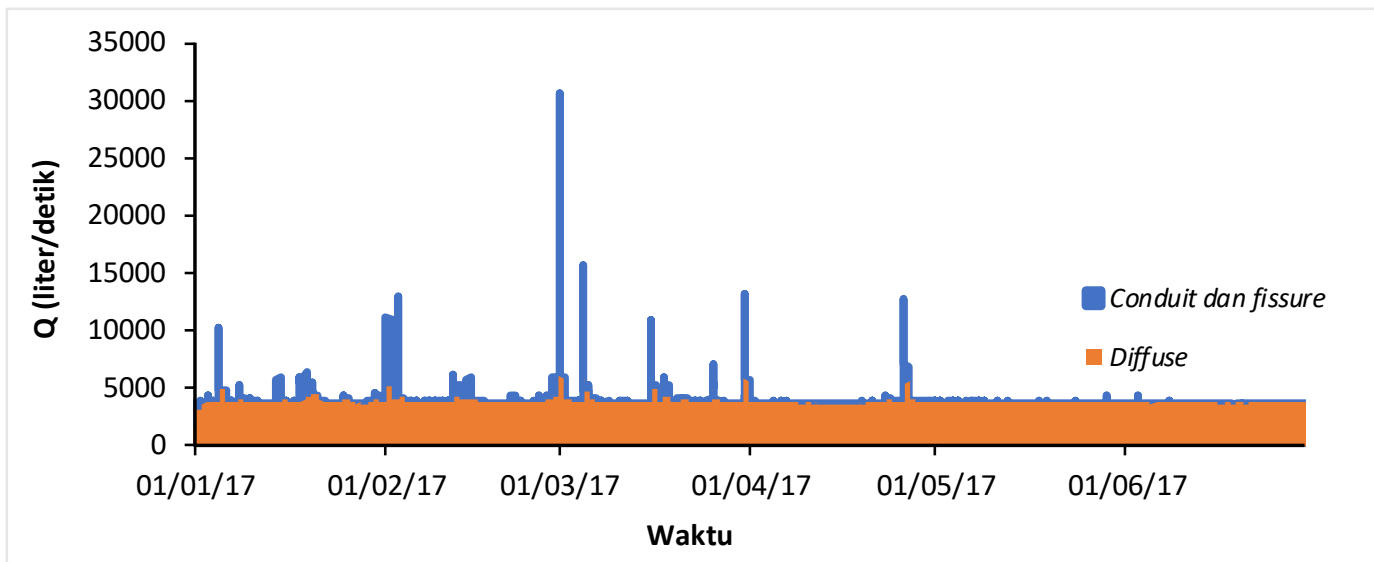

Gambar 4.11. Fluktuasi aliran dasar Gua Pindul selama kurun waktu 1 Januari 2017-30 Juni 2017

Tabel 4.8. PAD setiap kejadian banjir Gua Pindul

\begin{tabular}{lllll}
\hline No & Tanggal & Qp (lt/detik) & Qb (lt/detik) & PAD (\%) \\
\hline 1 & $5 / 1 / 2017$ & 10.320 & 4.271 & 41,39 \\
2 & $14 / 1 / 2017$ & 5.874 & 3.764 & 64,07 \\
3 & $1 / 2 / 2017$ & 11.132 & 5.041 & 45,29 \\
4 & $3 / 2 / 2017$ & 12.867 & 4.894 & 38,04 \\
5 & $14 / 2 / 2017$ & 6.019 & 4.144 & 68,85 \\
6 & $1 / 3 / 2017$ & 30.681 & 5.512 & 17,97 \\
7 & $5 / 3 / 2017$ & 15.666 & 4.371 & 27,9 \\
8 & $16 / 3 / 2017$ & 10.886 & 4.069 & 37,38 \\
9 & $25 / 3 / 2017$ & 7.006 & 4.375 & 62,45 \\
10 & $31 / 3 / 2017$ & 13.213 & 4.232 & 32,03 \\
11 & $26 / 4 / 2017$ & 12.647 & 4.615 & 36,49 \\
\hline Rata-Rata & & & 42,90 \\
Max & & & 68,85 \\
Min & & & & 17,97 \\
\hline
\end{tabular}

\subsubsection{Variasi Spasial dan Temporal Karakteristik Aliran Sistem Drainase}

\section{Karst Pindul}

Karakteristik aliran Sistem Drainase Karst Pindul dijelaskan oleh nilai konstanta resesi dan prosentase aliran dasar. Konstanta resesi mencerminkan 
pelepasan komponen aliran secara spasial antara Gua Pindul dengan Kedungbuntung. Prosentase aliran dasar mencerminkan simpanan aliran dasar secara spasial dan temporal.

\section{a. Variasi Spasial Pelepasan Komponen Aliran}

Nilai konstanta resesi dan parameter banjir di kedua lokasi ditunjukkan pada Tabel 4.9. Gua Pindul dan Kedungbuntung memiliki julat konstanta resesi $\left(\mathrm{K}_{\mathrm{b}}, \mathrm{K}_{\mathrm{i}}\right.$, dan $\mathrm{K}_{\mathrm{c}}$ ) besar. Hal ini menunjukkan bahwa Sistem Drainase Karst Pindul memiliki retakan diffuse, fissure, dan conduit dengan ukuran bervariasi.

Tabel 4.9. Ringkasan nilai konstanta resesi di Gua Pindul dan Kedungbuntung

\begin{tabular}{llll}
\hline Konstanta resesi & Gua Pindul & Kedungbuntung \\
\hline $\mathrm{K}_{\mathrm{b}}$ & $0,960-0,994 \quad($ rerata $=0,980)$ & $0,966-0,998 \quad($ rerata $=0,990)$ \\
$\mathrm{K}_{\mathrm{i}}$ & $0,596-0,848 \quad($ rerata $=0,705)$ & $0,558-0,890 \quad($ rerata $=0,760$ \\
$\mathrm{K}_{\mathrm{c}}$ & $0,155-0,544 \quad($ rerata $=0,303)$ & $0,246-0,439 \quad($ rerata $=0,325)$ \\
\hline
\end{tabular}

Variasi spasial nilai $\mathrm{K}_{\mathrm{b}}, \mathrm{K}_{\mathrm{i}}$, dan $\mathrm{K}_{\mathrm{c}}$ dianalisis menggunakan independent samples $t$-test. Metode ini merupakan salah satu uji hipotesis yang digunakan untuk mengetahui ada atau tidaknya perbedaan rata-rata antara dua sampel yang berbeda/independen (IBM, 2016). Dua sampel dikatakan memiliki perbedaan ratarata apabila nilai siginikansi lebih besar dari 0,05 (nilai taraf nyata yang digunakan pada penelitian ini). Dua sampel yang dimaksud pada penelitian ini adalah konstanta resesi Gua Pindul dan Kedungbuntung.

Hasil uji independent samples t-test dapat dilihat pada Tabel 4.10. Nilai siginifikansi $K_{b}, K_{i}$, dan $K_{c}$ pada kedua sampel memiliki nilai yang lebih besar dari taraf nyata. Hal ini menunjukkan bahwa Gua Pindul dan Kedungbuntung tidak memiliki perbedaan pelepasan komponen aliran. Tidak adanya perbedaan pelepasan komponen aliran tersebut disebabkan oleh karakteristik kedua lokasi.

Sinking stream Kedungbuntung dan Gua Pindul memiliki pelepasan aliran conduit yang cepat $\left(\mathrm{K}_{\mathrm{c}}<0,325\right)$, namun masih baik dalam menyimpan airtanah $\left(\mathrm{K}_{\mathrm{b}}\right.$ $>0,98$ ). Pelepasan aliran conduit yang cepat disebabkan oleh karakteristik Kedungbuntung yang berupa sungai permukaan sehingga limpasan permukaan langsung mengimbuh saluran sungai lalu dilepaskan dengan cepat. Sementara itu, Gua Pindul diimbuh oleh sungai bawah tanah dari sistem perguaan dan Sinking 
Stream Kedungbuntung (Haryono, 2011 dan Agniy 2016). Sungai bawah tanah memiliki karakteristik yang sama dengan sungai permukaan. Pelepasan aliran diffuse yang masih tergolong baik disebabkan karena kedua dilokasi diimbuh oleh akuifer dengan dominasi retakan diffuse seluas $13,7 \mathrm{~km}^{2}$ (88\% dari DTA).

Tabel 4.10. Uji independent samples t-test konstanta resesi Gua Pindul dengan Kedungbuntung

\begin{tabular}{lll}
\hline Konstanta resesi & Taraf nyata & Signifikansi \\
\hline $\mathrm{K}_{\mathrm{b}}$ & 0,05 & 0,31 \\
$\mathrm{~K}_{\mathrm{i}}$ & & 0.17 \\
$\mathrm{~K}_{\mathrm{c}}$ & & 0,58 \\
\hline
\end{tabular}

\section{b. Variasi Spasial dan Temporal Prosentase Aliran Dasar}

Rasio antara aliran dasar dengan debit aliran dapat ditampilkan dalam bentuk rasio setiap bulan dan setiap kejadian banjir. Rasio setiap bulan menunjukkan perbandingan antara total aliran dasar dengan total debit aliran per bulannya. Rasio setiap kejadian banjir menunjukkan perbandingan antara nilai aliran dasar dengan debit puncak pada setiap kejadian banjir terpilih.

Gua Pindul memiliki PAD bulanan yang lebih tinggi dibandingkan Kedungbuntung (Gambar 4.12). Besarnya PAD bulanan Gua Pindul dikarenakan Gua Pindul merupakan outlet dari sitem drainase karst. Hal ini menjadikannya memiliki daerah tangkapan air yang lebih luas dibandingkan Kedungbuntung. Selain itu, Gua Pindul mendapatkan imbuhan dari Sinking Stream Kedungbuntung dan sistem perguaan. Kedua imbuhan tersebut mampu menyimpan air yang dibuktikan dengan tetap adanya debit aliran pada musim kemarau. Meskipun demikian, kedua lokasi penelitian masih baik dalam menyimpan airtanah karena memiliki PAD bulanan yang lebih dari $95 \%$. Hasil ini mendukung nilai konstanta aliran diffuse $\left(\mathrm{K}_{\mathrm{b}}\right)$ yang memiliki nilai $>0,98$.

Tabel 4.11 dan Gambar 4.13 menunjukkan PAD Gua Pindul dan Kedungbuntung pada setiap kejadian banjir. Nilai PAD pada kejadian banjir dipengaruhi oleh besarnya banjir yang terjadi. PAD dengan nilai kecil dihasilkan oleh banjir besar (nilai $Q_{p}$ tinggi) tanggal 1 Maret dan 5 Maret 2017. PAD dengan nilai besar (PAD lebih besar dari 60\%) dihasilkan oleh banjir kecil (nilai $\mathrm{Q}_{\mathrm{p}}$ rendah) pada tanggal 14 Januari, 14 Februari, dan 25 Maret 2017. 
Tabel 4.11. PAD kejadian banjir di Gua Pindul dan Kedungbuntung

\begin{tabular}{lllll}
\hline Tanggal & PAD $(\%)$ & \multicolumn{2}{c}{ Taraf nyata } & Signifikansi \\
\cline { 2 - 3 } & Gua Pindul & \multicolumn{1}{c}{ Kedungbuntung } & & \\
\hline $5 / 1 / 2017$ & 41,39 & 48,15 & & \\
$14 / 1 / 2017$ & 64,07 & 60,69 & & \\
$1 / 2 / 2017$ & 45,29 & 50,89 & & \\
$3 / 2 / 2017$ & 38,04 & 48,90 & 0,05 & \multirow{2}{*}{0,513} \\
$14 / 2 / 2017$ & 68,85 & 72,23 & & \\
$1 / 3 / 2017$ & 17,97 & 24,26 & & \\
$5 / 3 / 2017$ & 27,9 & 33,73 & & \\
$16 / 3 / 2017$ & 37,38 & 41,05 & & \\
$25 / 3 / 2017$ & 62,45 & 63,76 & & \\
$31 / 3 / 2017$ & 32,03 & 35,57 & & \\
$26 / 4 / 2017$ & 36,49 & 40,07 & & \\
\hline rerata & 42,90 & 47,21 & & \\
max & 68,85 & 72,23 & & \\
min & 17,97 & 24,26 & & \\
\hline
\end{tabular}

Qp (debit puncak), Qb (aliran dasar), PAD (Prosentase Aliran Dasar)

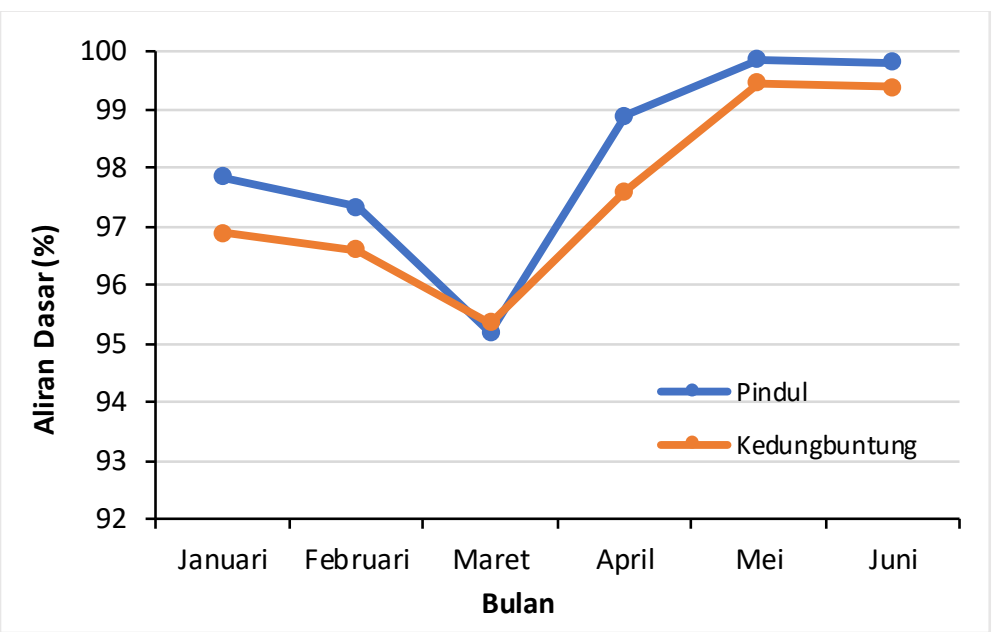

Gambar 4.12. Prosentase aliran dasar bulanan Gua Pindul dan Sinking Stream Kedungbuntung

PAD pada kejadian banjir antara Gua Pindul dengan Kedungbuntung tidak memiliki perbedaan yang signifikan. Nilai signifikansi antara kedua sampel menunjukkan nilai yang lebih besar dari taraf nyata (Tabel 4.11). Selain itu, Gambar 4.13 juga menunjukkan bentuk grafik yang identik. Hasil ini mendukung perhitungan konstanta resesi yang menyatakan bahwa Gua Pindul dan Kedungbuntung memiliki karakteristik pelepasan komponen aliran yang sama. 
Keduanya cepat melepaskan aliran conduit, namun masih baik dalam menyimpan airtanah.

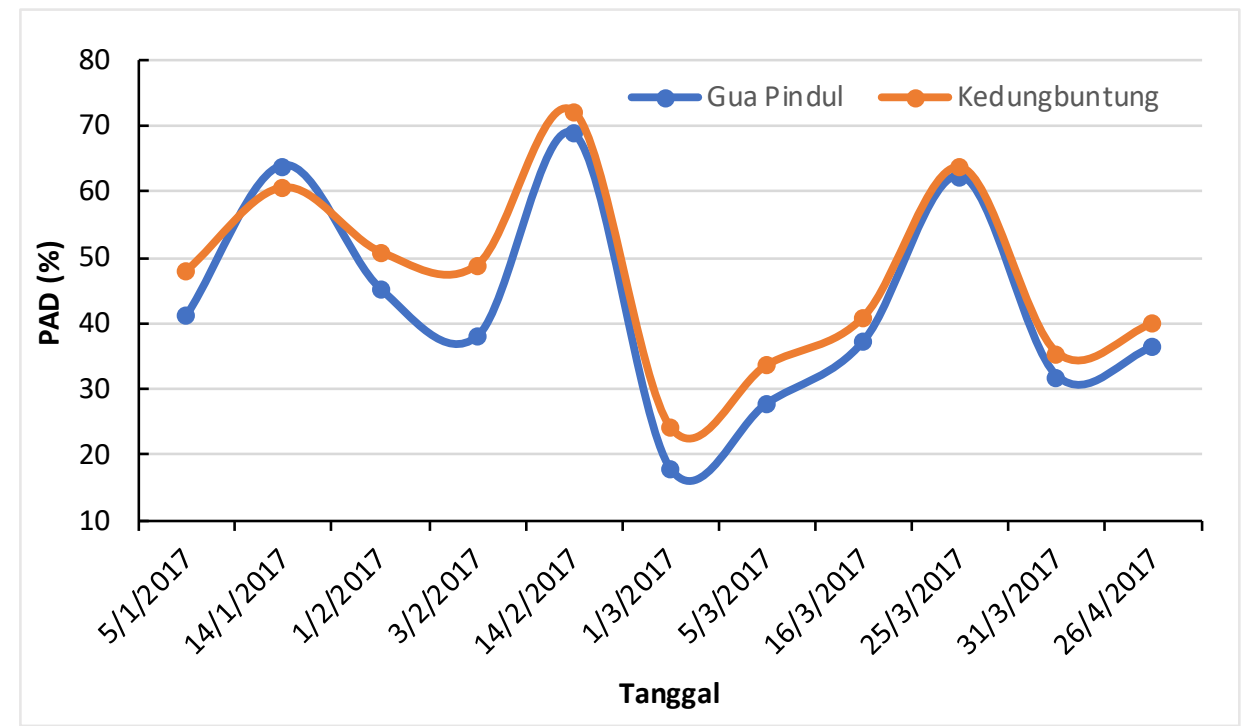

Gambar 4.13. PAD setiap kejadian banjir Gua Pindul dan Kedungbuntung

\subsection{Karakteristik Banjir}

\subsubsection{Sinking Stream Kedungbuntung}

Kedungbuntung mengalami 17 kejadian banjir selama bulan Januari hingga Juni tahun 2017. Secara sederhana, karakteristik dari setiap kejadian banjir dapat dilihat dari bentuk hidrograf banjirnya (Gambar 4.14.a dan b). Bentuk hidrograf tersebut dipengaruhi oleh karakteristik hujan dan daerah tangkapan air (Linsley, dkk, 1975). Kedungbuntung memiliki bentuk hidrograf dengan rising limb yang curam dan resesi yang perlahan-lahan. Hal ini dibuktikan dengan $T_{p}$ yang cepat dan $\mathrm{T}_{\mathrm{b}}$ yang lambat (Tabel 4.12). Nilai rerata $\mathrm{T}_{\mathrm{p}}(2 \mathrm{jam} 36$ menit) memiliki selisih yang kecil dengan rerata durasi hujan (2 jam 24 menit) sedangkan $\mathrm{T}_{\mathrm{b}}$ memiliki rerata 14 jam.

Karakteristik hujan yang dibahas pada penelitian ini adalah tebal hujan, durasi hujan, hujan puncak, dan hujan efektif (Tabel 4.12). Kedungbuntung memiliki julat tebal hujan 4,4-46,8 $\mathrm{mm}$ dengan rerata 22,8 $\mathrm{mm}$. Durasi hujan memiliki julat 30 menit-6 jam dengan rerata 2 jam 24 menit. Hujan puncak memiliki julat 1,4-17,6 mm dengan rerata $8,3 \mathrm{~mm}$. 

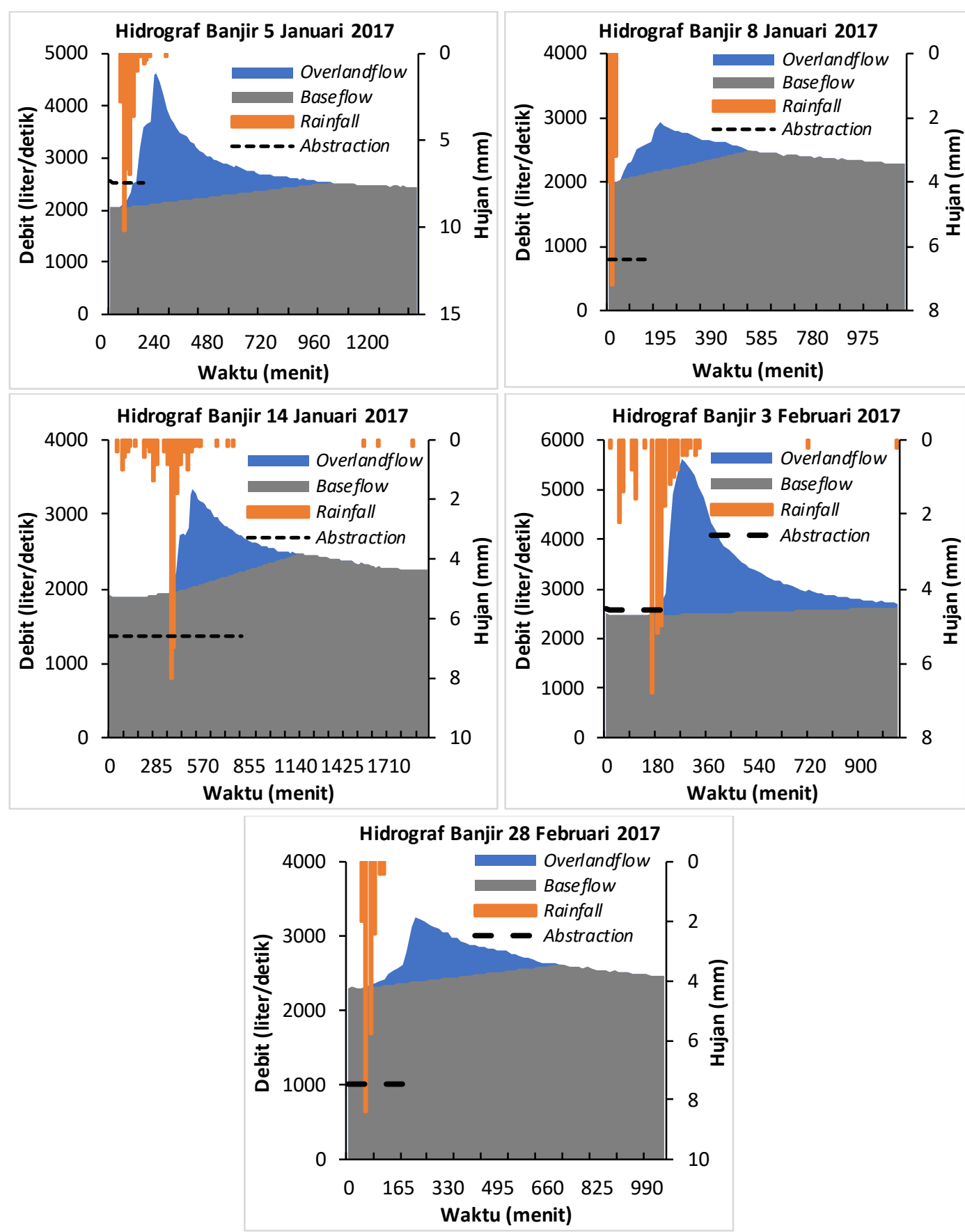

Gambar 4.14.a. Hidrograf banjir dan hyetograf awal musim hujan di Sinking Stream Kedungbuntung

Perhitungan hujan efektif memiliki asumsi bahwa hujan jatuh merata pada area penelitian (Chow, dkk, 1988; Davie 2008). Faktanya adalah tidak semua kejadian hujan jatuh merata di Sistem Drainase Karst Pindul. Perhitungan hujan efektif di penelitian ini hanya dapat dilakukan pada 9 kejadian banjir dari 17 kejadian di Kedungbuntung (Tabel 4.12). 

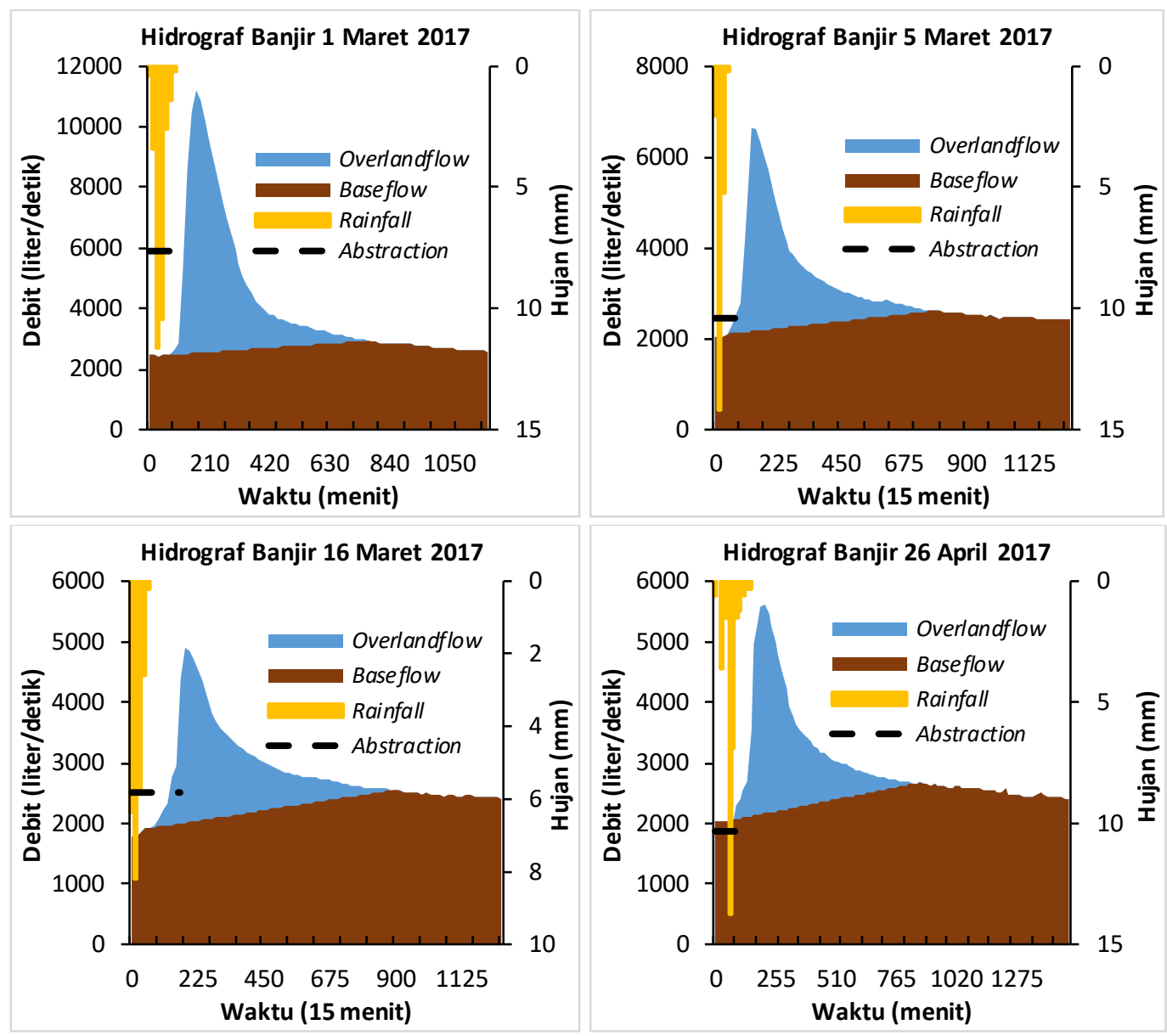

Gambar 4.14.b Hidrograf banjir dan hyetograf akhir musim hujan di Sinking Stream Kedungbuntung

Hujan efektif dihitung menggunakan konsep limpasan permukaan infiltration excess overland flow yang digagas oleh Horton (1933). Konsep ini menjelaskan bahwa limpasan pemukaan terjadi akibat intensitas hujan lebih tinggi dibandingkan kecepatan infiltrasi. DTA Kedungbuntung memiliki pori-pori batuan dan tanah yang telah jenuh oleh air ketika akhir musim hujan. Hal ini menyebabkan kecepatan infiltrasi menjadi lebih lambat dibandingkan pada awal musim hujan. Oleh karena itu, hujan dengan intensitas yang sama akan menyebabkan respons berbeda ketika terjadi pada awal musim hujan dan akhir musim hujan.

Kedungbuntung memiliki prosentase hujan yang menjadi limpasan permukaan (hujan efektif) lebih tinggi pada akhir musim hujan dibandingkan awal musim hujan (Tabel 4.12). Hujan efektif pada awal musim hujan memiliki nilai dengan dominasi kurang dari $10 \%$. Hujan efektif tertinggi pada musim tersebut 
terjadi pada tanggal 3 Februari 2017 dengan nilai 11,5\%. Nilai yang melebihi $10 \%$ terjadi akibat adanya hujan setebal 42,2 mm pada tanggal 1 Februari 2017. Hujan yang lebat ini menyebabkan sistem drainase menjadi jenuh sehingga hujan efektif menjadi tinggi ketika tejadi hujan dengan ketebalan 29,6 mm pada tanggal 3 Februari 2017.

Tabel 4.12. Komponen hidrograf banjir dan karakteristik hujan di Sinking Stream Kedungbuntung

\begin{tabular}{|c|c|c|c|c|c|c|c|c|c|c|}
\hline Musim & $\begin{array}{l}\text { Waktuawal } \\
\text { hujan }\end{array}$ & $\begin{array}{l}\mathrm{Q}_{\mathrm{p}} \\
\text { (lt/detik) }\end{array}$ & $\begin{array}{l}\mathrm{T}_{\mathrm{p}} \\
(\mathrm{jam})\end{array}$ & $\begin{array}{l}\mathrm{T}_{\mathrm{b}} \\
(\mathrm{jam})\end{array}$ & $\begin{array}{l}\text { Tebal } \\
\text { hujan } \\
(\mathrm{mm})\end{array}$ & $\begin{array}{l}\text { Durasi } \\
\text { hujan } \\
\text { (jam) }\end{array}$ & $\begin{array}{l}\text { Puncak } \\
\text { hujan } \\
\text { (mm) }\end{array}$ & $\phi$ & $\begin{array}{l}\text { Hujan } \\
\text { efetif } \\
(\mathrm{mm})\end{array}$ & $\begin{array}{l}\text { Hujan } \\
\text { efektif } \\
(\%)\end{array}$ \\
\hline \multirow{10}{*}{$\begin{array}{l}\text { Awal } \\
\text { Musim } \\
\text { Hujan }\end{array}$} & $\begin{array}{l}5 / 1 / 2017 \\
15: 30\end{array}$ & 4.626 & 2,50 & 13 & 32,6 & 2,25 & 10,2 & 7,3 & 2,9 & 8,9 \\
\hline & $\begin{array}{l}8 / 1 / 2017 \\
15: 15\end{array}$ & 2.934 & 2,25 & 15 & 14,4 & 0,50 & 7,2 & 6,4 & 0,8 & 5,5 \\
\hline & $\begin{array}{l}14 / 1 / 2017 \\
21: 30\end{array}$ & 3.341 & 2,25 & 11 & 21,4 & 2,25 & 8,0 & 6,6 & 1,8 & 8,5 \\
\hline & $\begin{array}{l}18 / 1 / 2017^{*} \\
21: 30\end{array}$ & 3.631 & 2,25 & 25 & 12,6 & 2,00 & 3,6 & - & - & - \\
\hline & $\begin{array}{l}20 / 1 / 2017^{*} \\
11: 00\end{array}$ & 3.112 & 3,00 & 13 & 9,8 & 1,75 & 4,6 & - & - & - \\
\hline & $\begin{array}{l}1 / 2 / 2017^{*} \\
17: 30\end{array}$ & 4.934 & 6,00 & 18 & 42,2 & 5,75 & 8,8 & - & - & - \\
\hline & $\begin{array}{l}3 / 2 / 2017 \\
2: 45\end{array}$ & 5.617 & 1,75 & 15 & 29,6 & 4,75 & 6,8 & 4,6 & 3,4 & 11,5 \\
\hline & $\begin{array}{l}12 / 2 / 2017^{*} \\
16: 45\end{array}$ & 3.326 & 2,25 & 11 & 6,8 & 2,75 & 1,4 & - & - & - \\
\hline & $\begin{array}{l}14 / 2 / 2017^{*} \\
20: 15\end{array}$ & 3.289 & 2,50 & 19 & 10,4 & 3,00 & 2,4 & - & - & - \\
\hline & $\begin{array}{l}28 / 2 / 2017 \\
20: 30\end{array}$ & 3.254 & 2,75 & 10 & 19,4 & 1,25 & 8,4 & 7,9 & 0,9 & 4,8 \\
\hline \multirow{7}{*}{$\begin{array}{l}\text { Akhir } \\
\text { Musim } \\
\text { Hujan }\end{array}$} & $\begin{array}{l}1 / 3 / 2017 \\
14: 15\end{array}$ & 11.215 & 1,50 & 10 & 30,0 & 1,50 & 11,6 & 7,6 & 6,8 & 22,5 \\
\hline & $\begin{array}{l}5 / 3 / 2017 \\
14: 00\end{array}$ & 6.644 & 1,25 & 11 & 21,6 & 0,75 & 14,2 & 10,4 & 3,8 & 17,6 \\
\hline & $\begin{array}{l}6 / 3 / 2017^{*} \\
11: 15\end{array}$ & 2.977 & 3,50 & 14 & 4,4 & 1,00 & 1,8 & - & - & - \\
\hline & $\begin{array}{l}16 / 3 / 2017 \\
17: 15\end{array}$ & 4.899 & 1,50 & 12 & 23,2 & 1,00 & 8,2 & 5,8 & 3,0 & 12,8 \\
\hline & $\begin{array}{l}25 / 3 / 2017^{*} \\
21: 45\end{array}$ & 3.532 & 5,00 & 16 & 31,4 & 6,00 & 12,0 & - & - & - \\
\hline & $\begin{array}{l}31 / 3 / 2017^{*} \\
15: 00\end{array}$ & 5.796 & 1,75 & 16 & 46,8 & 1,25 & 17,6 & - & - & - \\
\hline & $\begin{array}{l}26 / 4 / 2017 \\
17: 45\end{array}$ & 5.614 & 2,25 & 11 & 30,3 & 2,50 & 13,8 & 10,3 & 3,5 & 11,5 \\
\hline Rerata & - & 4.632 & 2,6 & 14 & 22,8 & 2,4 & 8,3 & 7,4 & 3,0 & 11,5 \\
\hline Max & - & 11.215 & 6,0 & 25 & 46,8 & 6,00 & 17,6 & 10,4 & 6,8 & 22,5 \\
\hline Min & - & 2.934 & 1,25 & 10 & 4,4 & 0,50 & 1,4 & 4,6 & 0,8 & 4,8 \\
\hline
\end{tabular}

pinitial abstraction (hujan yang mengalami infiltasi, penggenangan, atau evapotranspirasi [mm/ 15 menit]), * kejadian banjir yang tidak dapat dihitung hujan efektifnya

Hujan efektif pada akhir musim hujan memiliki nilai lebih dari $10 \%$ dengan nilai tertinggi $22,5 \%$ dan nilai terendah $11,5 \%$. Prosentase hujan efektif 
yang tinggi ini disebabkan oleh kecepatan infiltrasi yang menurun akibat pori-pori tanah dan batuan telah jenuh oleh hujan yang terjadi pada awal musim hujan. Tabel 4.12 menunjukkan bahwa hujan setebal 32,6 mm pada tanggal 5 Januari 2017 (awal musim hujan) menghasilkan hujan efektif sebesar 8,9\%. Sementara itu, hujan setebal 30,3 mm pada tanggal 26 April 2017 (akhir musim hujan) mampu menghasilkan $11,5 \%$ hujan efektif.

Pengaruh karakteristik hujan (tebal hujan, durasi hujan, puncak hujan, dan hujan efektif) terhadap respons sistem drainase karst yang berupa debit puncak $\left(\mathrm{Q}_{\mathrm{p}}\right)$ ditunjukkan pada Gambar 4.15 dan Tabel 4.13. Korelasi parsial (masing-masing karakteristik hujan) terhadap debit puncak menunjukkan bahwa hujan efektif memunyai pengaruh yang paling signifikan dengan nilai $R^{2}$ sebesar 0,97 . Sementara itu, tebal dan puncak hujan memiliki pengaruh yang tidak signifikan dengan nilai $\mathrm{R}^{2}$ 0,3 sedangkan durasi hujan memiliki pengaruh paling tidak signifikan dengan nilai $\mathrm{R}^{2} 0,002$ (Gambar 4.15).
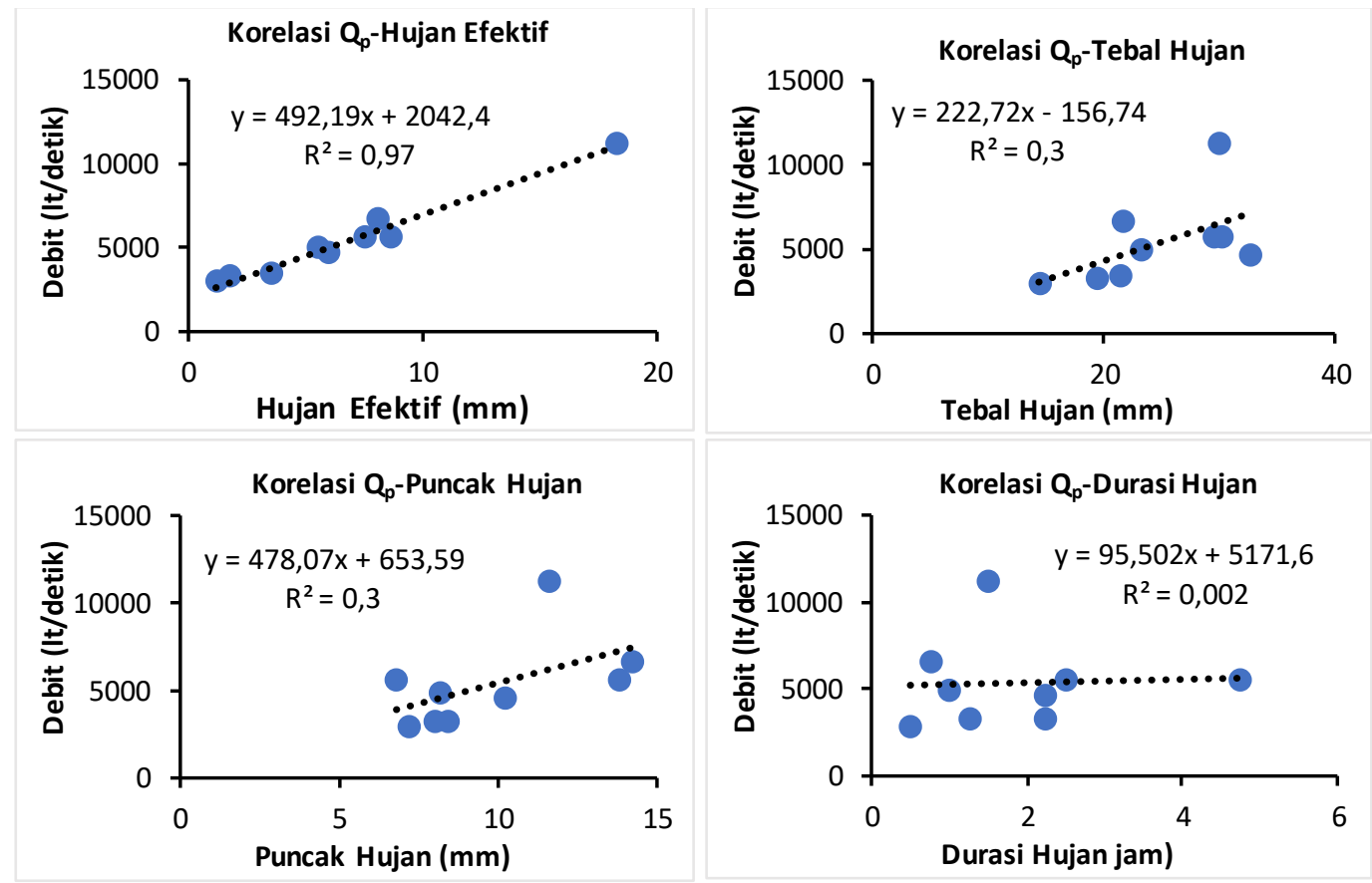

Gambar 4.15. Korelasi parsial karakteristik hujan dengan debit puncak di Sinking Stream Kedungbuntung

Tebal hujan, puncak hujan, dan durasi hujan memiliki pengaruh yang signifikan terhadap $\mathrm{Q}_{\mathrm{p}}$ apabila dilakukan uji korelasi secara simultan (bersamasama). Nilai $\mathrm{R}^{2}$ uji korelasi simultan adalah sebesar 0,9. Uji regresi linier 
menunjukkan bahwa tebal hujan dan puncak hujan memiliki hubungan yang berbanding lurus dengan $Q_{p}$. Hal ini berarti bahwa setiap bertambahnya nilai tebal hujan atau puncak hujan maka $Q_{p}$ juga akan bertambah. Durasi hujan memiliki hubungan yang berbanding terbalik dengan $Q_{p}$. Bertambahnya durasi hujan akan menyebabkan mengecilnya $Q_{p}$. Hal ini dikarenakan intensitas hujan akan menjadi kecil ketika hujan dengan ketebalan yang sama terjadi pada durasi hujan yang lebih panjang.

Tabel 4.13. Korelasi dan regresi simultan karakteristik hujan dengan debit puncak di Sinking Stream Kedungbuntung

\begin{tabular}{llcc}
\hline Karakteristik hujan & $P$-value & Taraf nyata & $\mathrm{R}^{2}$ \\
\hline Tebal & 0,31 & 0,05 & 0,9 \\
Puncak & 0,74 & & \\
Durasi & 0,56 & & \\
\hline Persamaan regresi & $\mathrm{Q}_{\mathrm{p}}=217$ tebal +120 & puncak - 598 durasi & \\
\hline
\end{tabular}

\subsubsection{Gua Pindul}

Gua Pindul juga mengalami 17 kejadian banjir selama 6 bulan waktu penelitian. Karakteristik hujan yang berupa tebal, puncak, dan durasi hujan memiliki nilai yang sama dengan Kedungbuntung. Hal ini disebabkan oleh letaknya yang berdekatan (700 meter). Perhitungan hujan efektif juga hanya dapat dilakukan pada 9 kejadian banjir. Gambar 4.16.a dan b menunjukkan bahwa hidrograf banjir memiliki rising limb yang cepat dan pelepasan komponen aliran yang perlahanlahan. Hal ini dibuktikan dengan cepatnya durasi waktu menunju puncak $\left(T_{p}\right)$ dan lamanya waktu menuju aliran dasar ( $\mathrm{T}_{\mathrm{b}}$ ) (Tabel 4.14). $\mathrm{T}_{\mathrm{p}}$ Gua Pindul memiliki julat 1,5-6 jam dengan rerata 2 jam 42 menit. Nilai $\mathrm{T}_{\mathrm{p}}(2,7$ jam) memiliki selisih yang kecil dengan durasi hujan (2,4 jam). $T_{b}$ Gua Pindul memiliki julat 10 jam-20 jam dengan rerata 14 jam.

Gua Pindul memiliki prosentase hujan efektif yang lebih besar pada akhir musim hujan dibandingkan awal musim hujan (Tabel 4.14). Hujan efektif pada awal musim hujan memiliki dominasi kurang dari 20\%. Hujan efektif pada tanggal 3 Februari 2017 memiliki nilai 29,1\% (lebih dari 20\%). Hal ini disebabkan oleh adanya hujan setebal 42,2 mm pada tanggal 1 Februari 2017 sehingga kondisi sistem drainase menjadi jenuh air. Hujan efektif pada akhir musim hujan memiliki nilai lebih dari $20 \%$ dengan nilai tertinngi $60,7 \%$ dan terendah $23,9 \%$. 

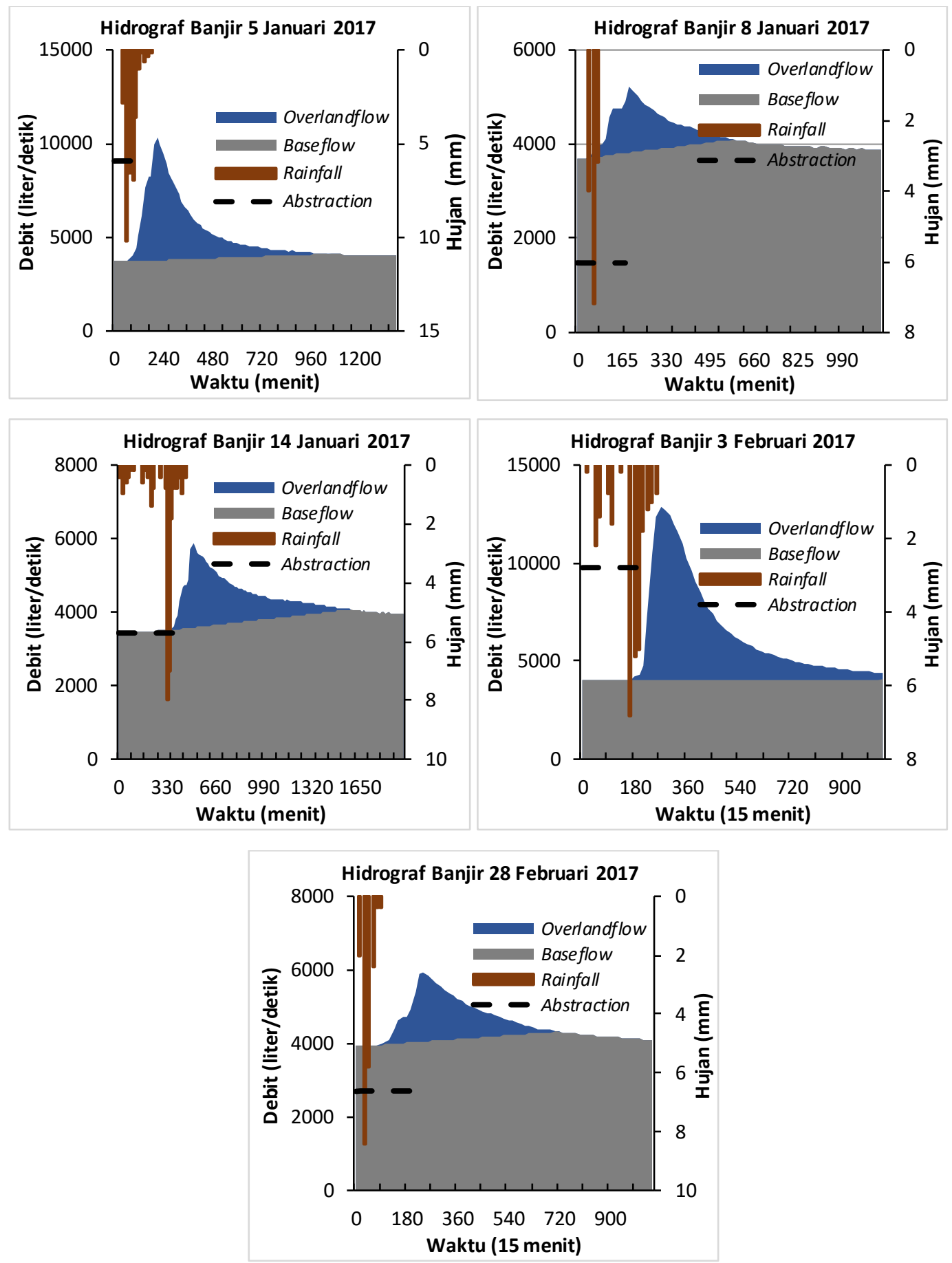

Gambar 4.16.a. Hidrograf banjir dan hyetograf awal musim hujan di Gua Pindul

Pengaruh karakteristik hujan terhadap debit puncak $\left(\mathrm{Q}_{\mathrm{p}}\right)$ dapat dilihat pada Gambar 4.17 dan Tabel 4.15. Korelasi secara parsial menunjukkan bahwa hujan efektif memiliki pengaruh yang paling signifikan dengan nilai $\mathrm{R}^{2} 0,96$ (Gambar 
4.17). Tebal hujan dan puncak hujan memiliki pengaruh yang tidak signifikan terhadap debit puncak (memiliki $\mathrm{R}^{2} 0,3$ ). Durasi hujan memiliki pengaruh yang paling tidak signifikan dengan nilai $\mathrm{R}^{2} 0,001$.
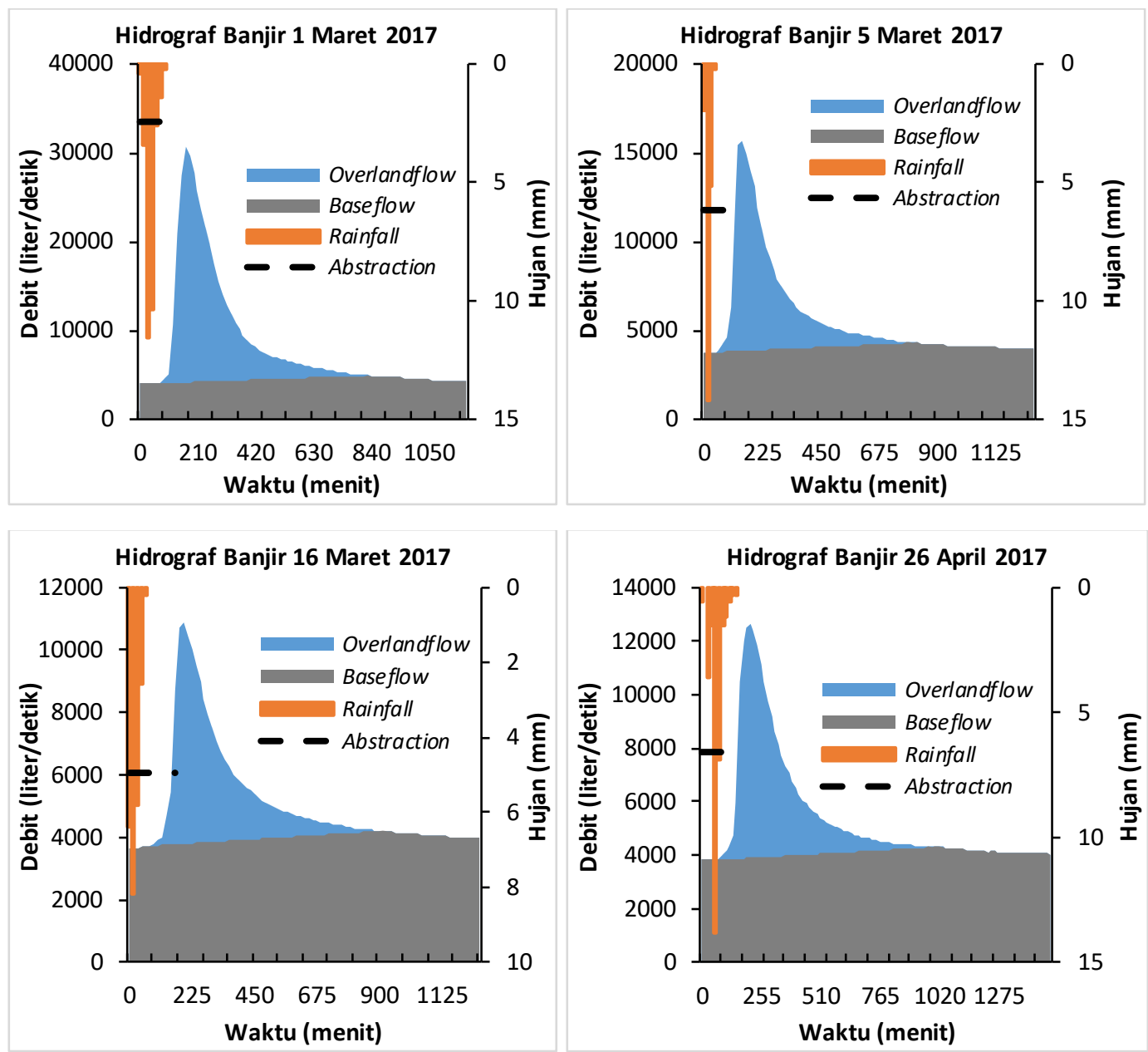

Gambar 4.16.b. Hidrograf banjir dan hyetograf akhir musim hujan di Gua Pindul

Uji korelasi dan regresi secara simultan menunjukkan bahwa tebal hujan, puncak hujan, dan durasi hujan memiliki pengaruh yang signifikan terhadap $Q_{p}$. Uji korelasi memiliki nilai $\mathrm{R}^{2}$ 0,83 (Tabel 4.15). Sementara itu, tebal hujan dan puncak hujan memiliki hubungan yang berbanding lurus dengan $Q_{p}$ yang ditunjukkan oleh koefisien regresi +639 dan +88 . Sementara itu, durasi hujan memiliki hubungan yang berbanding terbalik dengan $\mathrm{Q}_{\mathrm{p}}$ yang ditunjukkan oleh koefisien bernilai -2152 pada uji regresi. 
Tabel 4.14. Komponen hidrograf banjir dan karakteristik hujan di Gua Pindul

\begin{tabular}{|c|c|c|c|c|c|c|c|c|c|c|}
\hline Musim & $\begin{array}{l}\text { Waktu Awal } \\
\text { Hujan }\end{array}$ & $\begin{array}{l}\mathrm{Qp}_{\mathrm{p}} \\
\text { (lt/detik) }\end{array}$ & $\begin{array}{l}\mathrm{T}_{\mathrm{p}} \\
(\mathrm{jam})\end{array}$ & $\begin{array}{l}\mathrm{T}_{\mathrm{b}} \\
\text { (jam) }\end{array}$ & $\begin{array}{l}\text { Tebal } \\
\text { Hujan } \\
(\mathrm{mm})\end{array}$ & $\begin{array}{l}\text { Durasi } \\
\text { Hujan } \\
\text { (jam) }\end{array}$ & $\begin{array}{l}\begin{array}{l}\text { Puncak } \\
\text { Hujan } \\
(\mathrm{mm})\end{array} \\
\end{array}$ & $\phi$ & $\begin{array}{l}\text { Hujan } \\
\text { Efetif } \\
(\mathrm{mm})\end{array}$ & $\begin{array}{l}\text { Hujan } \\
\text { Efektif } \\
(\%)\end{array}$ \\
\hline \multirow{11}{*}{$\begin{array}{l}\text { Awal } \\
\text { Hujan }\end{array}$} & $5 / 1 / 2017$ & 10.320 & 2,5 & 15 & 32,6 & 2,25 & 10,2 & 5,9 & 6 & 18,4 \\
\hline & $15: 30$ & & & & & & & & & \\
\hline & $\begin{array}{l}8 / 1 / 2017 \\
15: 15\end{array}$ & 5.221 & 2,25 & 15 & 14,4 & 0,5 & 7,2 & 6 & 1,2 & 8,1 \\
\hline & $\begin{array}{l}14 / 1 / 2017 \\
21: 30\end{array}$ & 5.874 & 2,25 & 18 & 21,4 & 2,25 & 8 & 5,7 & 3,6 & 16,7 \\
\hline & $18 / 1 / 2017^{*}$ & 6.941 & 2,25 & 18 & 12,6 & 2 & 3,6 & - & - & - \\
\hline & $\begin{array}{l}21: 30 \\
20 / 1 / 2017^{*} \\
11: 00\end{array}$ & 5.421 & 3 & 16 & 9,8 & 1,75 & 4,6 & - & - & - \\
\hline & $\begin{array}{l}1 / 2 / 2017^{*} \\
17: 30\end{array}$ & 11.132 & 6 & 14 & 42,2 & 5,75 & 8,8 & - & - & - \\
\hline & $\begin{array}{l}3 / 2 / 2017 \\
2: 45\end{array}$ & 12.867 & 1,75 & 20 & 29,6 & 4,75 & 6,8 & 2,8 & 8,6 & 29,1 \\
\hline & $\begin{array}{l}12 / 2 / 2017^{*} \\
16: 45\end{array}$ & 6.045 & 2,5 & 16 & 6,8 & 2,75 & 1,4 & - & - & - \\
\hline & $14 / 2 / 2017^{*}$ & 6.019 & 2,75 & 12 & 10,4 & 3 & 2,4 & - & - & - \\
\hline & $\begin{array}{l}20: 15 \\
28 / 2 / 2017 \\
20: 30\end{array}$ & 5.927 & 3 & 10 & 19,4 & 1,25 & 8,4 & 6,6 & 1,8 & 9,2 \\
\hline \multirow{7}{*}{$\begin{array}{l}\text { Akhir } \\
\text { Hujan }\end{array}$} & $1 / 3 / 2017$ & 30.681 & 1,5 & 11 & 30 & 1,5 & 11,6 & 2,4 & 18,2 & 60,7 \\
\hline & $\begin{array}{l}5 / 3 / 2017 \\
14: 00\end{array}$ & 15.666 & 1,5 & 11 & 21,6 & 0,75 & 14,2 & 6,2 & 8 & 37,2 \\
\hline & $\begin{array}{l}6 / 3 / 2017^{*} \\
11: 15\end{array}$ & 5.193 & 3,25 & 10 & 4,4 & 1 & 1,8 & - & - & - \\
\hline & $\begin{array}{l}16 / 3 / 2017 \\
17: 15\end{array}$ & 10.886 & 1,75 & 12 & 23,2 & 1 & 8,2 & 5 & 5,6 & 23,9 \\
\hline & $\begin{array}{l}25 / 3 / 2017^{*} \\
21: 45\end{array}$ & 7.006 & 5,25 & 10 & 31,4 & 6 & 12 & - & - & - \\
\hline & $\begin{array}{l}31 / 3 / 2017^{*} \\
15: 00\end{array}$ & 13.213 & 1,75 & 11 & 46,8 & 1,25 & 17,6 & - & - & - \\
\hline & $\begin{array}{l}26 / 4 / 2017 \\
17: 45\end{array}$ & 12.647 & 2,25 & 13 & 30,3 & 2,5 & 13,8 & 6,6 & 7,5 & 24,8 \\
\hline Rerata & - & 10.062 & 2,7 & 14 & 22,8 & 2,4 & 8,3 & 5,2 & 6,7 & 25,4 \\
\hline $\operatorname{Max}$ & - & 30.681 & 6 & 20 & 46,8 & 6 & 17,6 & 6,6 & 18,2 & 60,7 \\
\hline Min & - & 5.193 & 1,5 & 10 & 4,4 & 0,5 & 1,4 & 2,4 & 1,2 & 8,1 \\
\hline
\end{tabular}

pinitial abstraction (hujan yang mengalami infiltasi, penggenangan, atau evapotranspirasi [mm/ 15 menit]), "kejadian banjir yang tidak dapat dihitung hujan efektifnya

Tabel 4.15. Korelasi dan regresi simultan karakteristik hujan dengan debit puncak di Gua Pindul

\begin{tabular}{llcc}
\hline Karakteristik hujan & $P$-value & Taraf nyata & $\mathrm{R}^{2}$ \\
\hline Tebal & 0,35 & 0,05 & 0,83 \\
Puncak & 0,94 & & \\
Durasi & 0,52 & & \\
\hline Persamaan regresi & $\mathrm{Q}_{\mathrm{p}}=639$ tebal +88 puncak -2152 durasi & \\
\hline
\end{tabular}



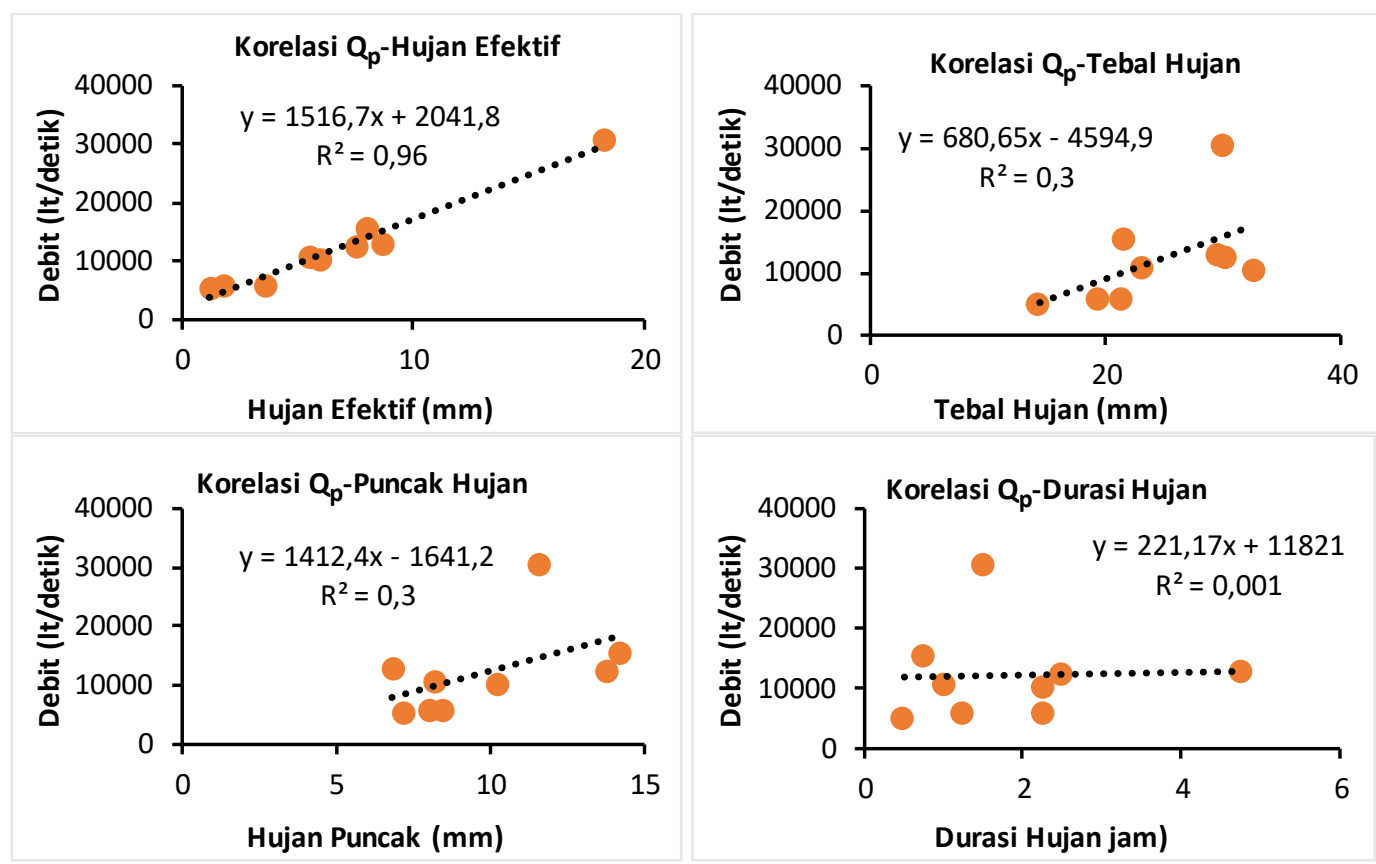

Gambar 4.17. Korelasi parsial karakteristik hujan dengan debit puncak di Gua Pindul

\subsubsection{Variasi Spasial dan Temporal Karakteristik Banjir Sistem Drainase Karst Pindul}

Variasi karakteristik banjir dianalisis berdasarkan karakteristik hidrograf banjir $\left(Q_{p}, T_{p}\right.$, dan $\left.T_{b}\right)$ dan karakteristik hujan (tebal, puncak, durasi, dan hujan efektif. Parameter $\mathrm{T}_{\mathrm{p}}$ dan $\mathrm{T}_{\mathrm{b}}$ antara Gua Pindul dengan Kedungbuntung memiliki perilaku yang sama. Hal ini ditunjukkan dengan nilai signifikansi yang lebih besar dari taraf nyata (Tabel 4.16). Nilai $\mathrm{T}_{\mathrm{p}}$ dan $\mathrm{T}_{\mathrm{b}}$ menunjukkan bahwa kedua lokasi memiliki respons banjir yang cepat $\left(T_{p}<2,7\right.$ jam), namun masih baik dalam menyimpan airtanah $\left(\mathrm{T}_{\mathrm{b}}>10 \mathrm{jam}\right)$. Respons banjir yang cepat disebabkan oleh karakteristik Kedungbuntung yang berupa sungai permukaan dan Gua Pindul yang diimbuh oleh sungai bawah tanah dan Kedungbuntung. Sementara itu, adanya akuifer dengan dominasi retakan diffuse menyebabkan kedua lokasi tergolong masih baik dalam dalam menyimpan airtanah.

Gua Pindul dan Kedungbuntung memiliki karakteristik $Q_{p}$ yang berbeda. Tabel 4.16 menunjukkan bahwa nilai signifikansi $Q_{p}$ lebih kecil dari taraf nyata. Gua Pindul memiliki $Q_{p}$ yang lebih besar dibandingkan Kedungbuntung (Tabel 4.16). Hal ini disebabkan oleh posisi Gua Pindul yang merupakan outlet sistem 
drainase karst. Posisi Gua Pindul tersebut menyebabkannya memiliki daerah tangkapan yang lebih luas dibandingkang Kedungbuntung. Kedua kondisi diatas juga mengakibatkan prosentase hujan efektif Gua Pindul lebih besar dibandingkan Kedungbuntung (Tabel 4.17).

Tabel 4.16. Nilai $\mathrm{Q}_{\mathrm{p}}, \mathrm{T}_{\mathrm{p}}, \mathrm{T}_{\mathrm{b}}$, dan signifikansi di Gua Pindul dan Kedungbuntung

\begin{tabular}{|c|c|c|c|c|c|c|c|c|c|c|}
\hline \multirow[t]{2}{*}{ Ket. } & \multicolumn{2}{|c|}{$\mathrm{Q}_{\mathrm{p}}(\mathrm{lt} / \mathrm{dt})$} & \multicolumn{2}{|c|}{$\mathrm{T}_{\mathrm{p}}(\mathrm{jam})$} & \multicolumn{2}{|c|}{$\mathrm{T}_{\mathrm{b}}(\mathrm{jam})$} & \multirow{2}{*}{$\begin{array}{l}\text { Taraf } \\
\text { nyata }\end{array}$} & \multicolumn{3}{|c|}{ Signifikansi } \\
\hline & GP & KG & GP & $\mathrm{KG}$ & GP & $\mathrm{KG}$ & & $\mathrm{Q}_{\mathrm{p}}$ & $T_{p}$ & $\mathrm{~T}_{\mathrm{b}}$ \\
\hline $\min$ & 5.221 & 2.934 & 1,5 & 1,25 & 14 & 14 & & & & \\
\hline $\max$ & 30.681 & 11.215 & 6 & 6 & 20 & 25 & 0,05 & 0,02 & 0,86 & 0,7 \\
\hline rerata & 10.062 & 4.632 & 2,7 & 2,6 & 10 & 10 & & & & \\
\hline
\end{tabular}

Secara temporal, kedua lokasi memiliki prosentase hujan efektif yang lebih besar pada akhir musim hujan dibandingkan awal musim hujan (Tabel 4.17). Gua Pindul memiliki rerata hujan efektif $16,3 \%$ pada awal musim hujan dan 36,6\% pada akhir musim hujan. Sementara itu, Kedungbuntung memiliki hujan efektif $16,1 \%$ dan $7,84 \%$. Kondisi tersebut disebabkan oleh jenuhnya sistem drainase karst pada akhir musim hujan sehingga hujan dengan intensitas yang sama akan menghasilkan limpasan permukaan lebih tinggi pada akhir musim hujan.

Tabel 4.17 Nilai $\mathrm{P}_{\mathrm{e}}$ di Gua Pindul dan Kedungbuntung

\begin{tabular}{lllllll}
\hline \multirow{2}{*}{ Ket. } & \multicolumn{2}{l}{$\mathrm{P}_{\mathrm{e}}(\%)$} & & \multicolumn{2}{l}{$\mathrm{P}_{\mathrm{e}}$ awal hujan $(\%)$} & \multicolumn{2}{l}{$\mathrm{P}_{\mathrm{e}}$ akhir hujan (\%) } \\
\cline { 2 - 7 } & GP & KG & GP & KG & GP & KG \\
\hline $\min$ & 8,1 & 4,8 & 8,1 & 4,8 & 23,9 & 11,5 \\
$\max$ & 60,7 & 22,5 & 29,1 & 11,5 & 60,7 & 22,5 \\
rerata & 25,4 & 11,5 & 16,3 & 7,8 & 36,6 & 16,1 \\
\hline
\end{tabular}

$P e$ hujan efektif, GP Gua Pindul, $K G$ Kedungbuntung

Pengaruh karakteristik hujan terhadap debit puncak dianalis is menggunakan korelasi parsial dan simultan. Korelasi parsial menunjukkan bahwa hujan efektif merupakan karakterisik hujan yang memiliki pengaruh paling signifikan terhadap debit puncak di kedua lokasi penelitian. Hal ini ditunjukkan dengan $\mathrm{R}^{2}$ yang bernilai 0,96 di Gua Pindul dan 0,97 di Kedungbuntung (Tabel 4.18).

Pada uji korelasi parsial, tebal hujan, puncak hujan, dan durasi hujan memiliki pengaruh yang tidak signifikan terhadap debit puncak. Hal tersebut 
ditunjukkan oleh nilai $\mathrm{R}^{2}$ yang rendah dan $p$-value yang lebih besar dari taraf nyata (Tabel 4.18 dan 4.19). Menurut Juanda dan Junaidi (2012), variabel dengan nilai $p$ value yang lebih besar dari taraf nyata dinyatakan sebagai variabel yang secara parsial tidak berpengaruh signifikan. Rendahnya pengaruh ini dikarenakan ketiga karakteristik hujan dihitung sebelum adanya pengaruh dari sistem drainase karst. Sementara itu, hujan efektif dihitung setelah adanya pengaruh dari sistem drainase karst, yaitu abstraksi (infiltrasi, intersepsi, dan komponen simpanan) (Chow, dkk, 1988).

Tabel 4.18. Nilai $\mathrm{R}^{2}$ uji korelasi parsial antara debit puncak dengan karakteristik hujan di Gua Pindul dan Kedungbuntung

\begin{tabular}{lllll}
\hline & Hujan efektif & Tebal hujan & Puncak hujan & Durasi hujan \\
\hline Gua Pindul & 0,96 & 0,3 & 0,3 & 0,001 \\
Kedungbuntung & 0,97 & 0,3 & 0,3 & 0,002 \\
\hline
\end{tabular}

Tabel 4.19. Uji korelasi simultan dan regresi linier antara debit puncak dengan tebal, puncak, dan durasi hujan di Gua Pindul dan Kedungbuntung

\begin{tabular}{llllll}
\hline $\begin{array}{l}\text { Karakteristik } \\
\text { hujan }\end{array}$ & $\begin{array}{l}\text { Taraf } \\
\text { nyata }\end{array}$ & \multicolumn{3}{l}{ Gua Pindul } & \multicolumn{3}{l}{ Kedungbuntung } \\
\cline { 2 - 6 } & & $p$-value & $\mathrm{R}^{2}$ & $p$-value & $\mathrm{R}^{2}$ \\
\hline Tebal & 0,05 & 0,35 & 0,83 & 0,31 & 0,9 \\
Puncak & & 0,94 & & 0,74 & \\
Durasi & & 0,52 & 0,56 & \\
\hline Persamaan & & $\mathrm{Qp}=639$ tebal +88 puncak & $\mathrm{Q}_{\mathrm{p}}=217$ tebal +120 puncak \\
regresi linier & & \multicolumn{2}{c}{-2152 durasi } & & \\
\hline
\end{tabular}

Ketiga karakteristik hujan (tebal, puncak, dan durasi hujan) memiliki pengaruh yang signifikan terhadap debit puncak apabila dilakukan uji korelasi secara simultan. Tabel 4.19 menunjukkan bahwa Gua Pindul memiliki $\mathrm{R}^{2} 0,83$ sedangkan Kedungbuntung 0,9. Nilai $\mathrm{R}^{2}$ Gua Pindul yang lebih rendah disebabkan karena adanya dominasi retakan conduit yang mengimbuhnya (imbuhan melalui sistem perguaan). Adanya dominasi retakan conduit memungkinkan debit aliran setelah terjadinya hujan tidak mengalir melalui outlet sistem karst (Smart, 1988). Sementara itu, uji regresi linier menunjukkan bahwa tebal dan puncak hujan memiliki hubungan yang berbanding lurus dengan debit puncak sedangkan durasi hujan memiliki hubungan yang berbanding terbalik. Hal tersebut ditunjukkan oleh koefisien yang bernilai positif pada tebal dan puncak hujan sedangkan durasi hujan memiliki koefisien yang bernilai negatif. 


\subsection{Karakteristik Respons Sistem Drainase Karst Terhadap Curah Hujan}

Respons sistem drainase karst terhadap hujan dihitung menggunakan time series analysis yang telah diklasifikasikan oleh Zang, dkk (2013). Penelitian ini memodifikasi klasifikasi tersebut. Modifikasi ini menghasilkan klasifikasi respons sistem drainase karst terhadap aliran conduit, fissure, dan diffuse.

\subsubsection{Respons Aliran Conduit}

Respons aliran conduit dihitung berdasarakan waktu tunda aliran conduit ( $\mathrm{T}_{\mathrm{lag}}$ ) dan durasi maksimum pelepasan aliran conduit. Tlag didapatkan melalui perhitungan cross-correlation, phase functions, dan cross-amplitude. Tlag identik dengan $T_{p}$ yang telah dibahas pada sub bab karakteristik banjir. Durasi maksimum pelepasan aliran conduit didapatkan melalui perhitungan gain functions. Perhitungan $\mathrm{T}_{\text {lag }}$ menggunakan konsep rising limb sedangkan durasi maksimum pelepasan aliran conduit menggunakan konsep resesi pada hidrograf banjir.

$\mathrm{T}_{\text {lag }}$ aliran conduit ditunjukkan oleh nilai cross-correlation $\left(\mathrm{C}_{\mathrm{xy}}\right)$ tertinggi, Gambar 4.18 menunjukkan bahwa kedua lokasi penelitian memiliki $\mathrm{C}_{\mathrm{xy}}$ tertinggi pada $T_{\text {lag }} 105$ menit (0,406 di Gua Pindul dan 0,366 di Kedungbuntung). Hal ini menunjukkan bahwa kedua lokasi memiliki waktu tunda aliran conduit ( $\left.\mathrm{T}_{\text {lag }}\right) 105$ menit (1 jam 45 menit). T lag yang bernilai positif (105 menit) juga menunjukkan bahwa debit aliran memiliki hubungan yang berbanding lurus dengan curah hujan.

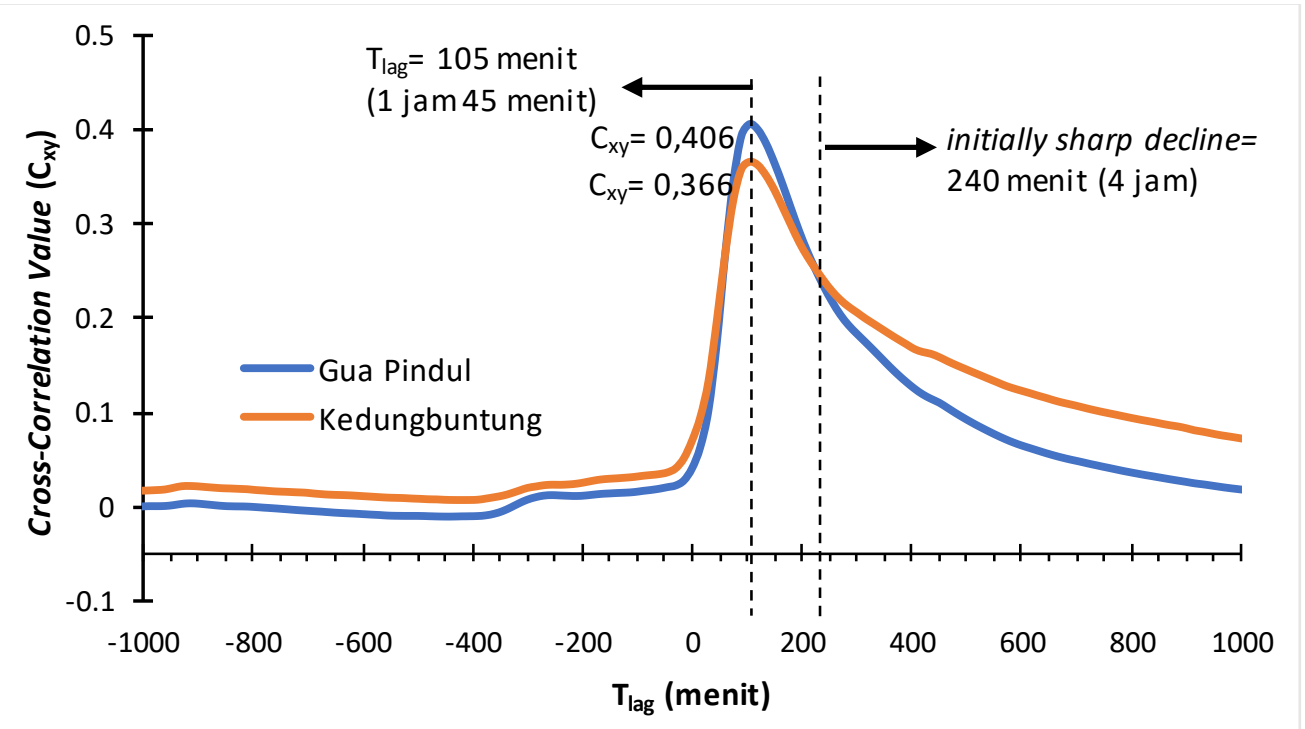

Gambar 4.18. Grafik cross-correlation Gua Pindul dan Kedungbuntung 
Phase functions menunjukkan perbedaan frekuensi antara input (hujan) dengan output (debit aliran). Perbedaan ini disebabkan adanya pemfilteran hujan oleh sistem drainase karst (Panagopoulus dan Lambarakis, 2006). Gambar 4.19 menunjukkan adanya aliran conduit pada frekuensi $0,9 \times 10^{-4}$ hingga $62,4 \times 10^{-4}$ yang menyebabkan bentuk grafik menjadi naik-turun secara kontinu. Rerata waktu tunda aliran conduit dihitung pada julat frekuensi tersebut menggunakan persamaan 30 . Gua Pindul memiliki $\mathrm{T}_{\text {lag }} 1$ jam 45 menit, sedangkan Kedungbuntung memiliki $\mathrm{T}_{\text {lag }}$ 1 jam 36 menit.

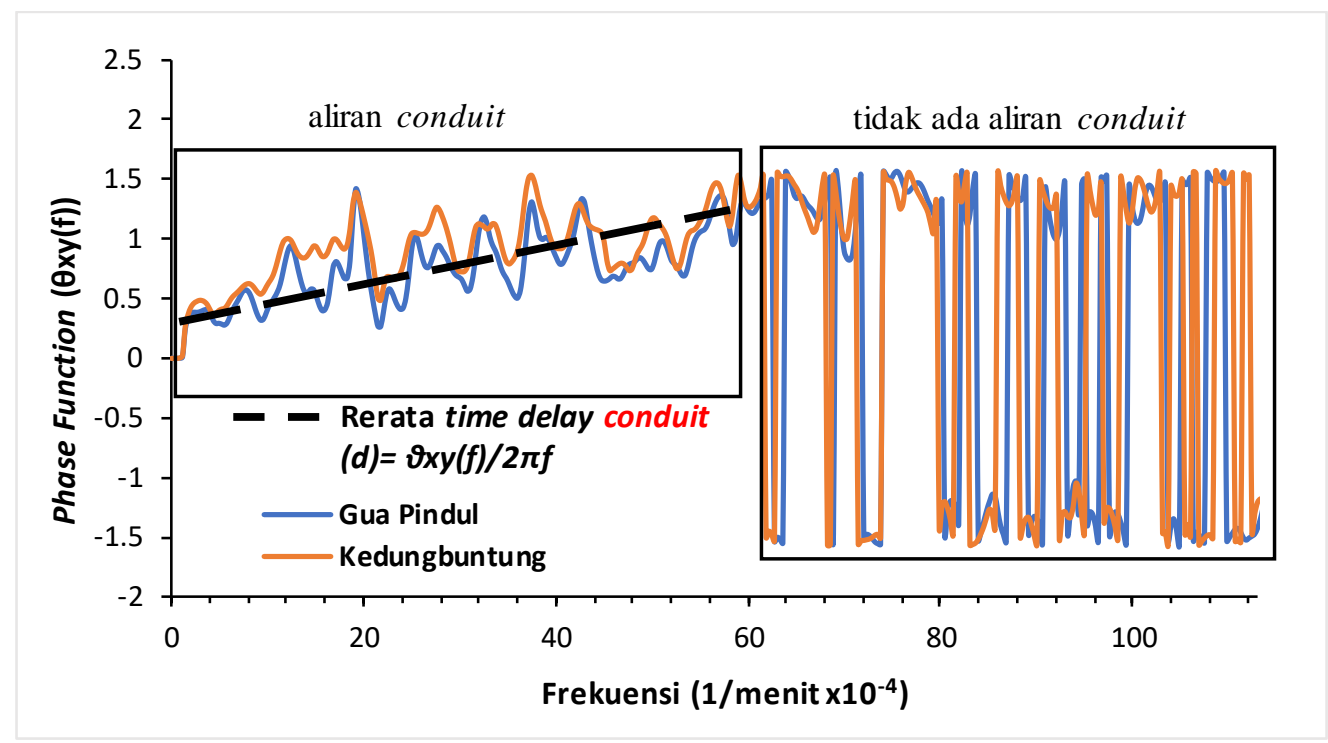

Gambar 4.19. Grafik phase functions Gua Pindul dan Kedungbuntung

Cross-amplitude $\left(\mathrm{S}_{\mathrm{xy}}\right)$ menunjukkan karakteristik pemfilteran input signal (hujan) oleh sistem karst sebelum keluar sebagai output signal (debit aliran). Menurut Zang, dkk (2013), nilai tersebut merupakan Tlag maksimum aliran conduit. $\mathrm{T}_{\text {lag }}$ maksimum ini didapatkan ketika $\mathrm{S}_{\mathrm{xy}}$ mendekati nol pada grafik. Karst yang belum berkembang akan memfilter signal pada frekuensi tinggi (waktu cepat) sehingga memiliki $S_{x y}$ mendekati nol pada frekuensi rendah (waktu lama). Gua Pindul dan Kedungbuntung memiliki $S_{x y}$ mendekati nol pada frekuensi $94 \times 10^{-4}$ (Gambar 4.20 dan 4.21). Oleh karena itu, keduanya memiliki $\mathrm{T}_{\text {lag }}$ maksimum <1 jam 46 menit.

Gain functions $\left(\mathrm{G}_{\mathrm{xy}}\right)$ menunjukkan durasi maksimum pelepasan aliran conduit ketika nilai $\mathrm{G}_{\mathrm{xy}}$ pada grafik memiliki nilai $<0,4$. Angka ini merupakan nilai 
yang ditetapkan oleh Padilla dan Pulido-Bosch (1995). Gambar 4.22 menunjukkan Gua Pindul memiliki $G_{x y}$ dengan nilai $<0,4$ pada frekuensi $>550 \times 10^{-4}$ (durasi= $[1 / 550] \times 10^{4}=18$ menit). Sementara itu, Kedungbuntung memiliki $\mathrm{G}_{\mathrm{xy}}$ dengan nilai $<0,4$ pada frekuensi $>330 \times 10^{-4}$ (durasi $=[1 / 330] \times 10^{4}=30$ menit) (Gambar 4.23). Hal ini menunjukkan bahwa Gua Pindul memiliki durasi pelepaan aliran conduit yang lebih cepat (<18 menit) dibandingkan Kedungbuntung ( $<30$ menit).

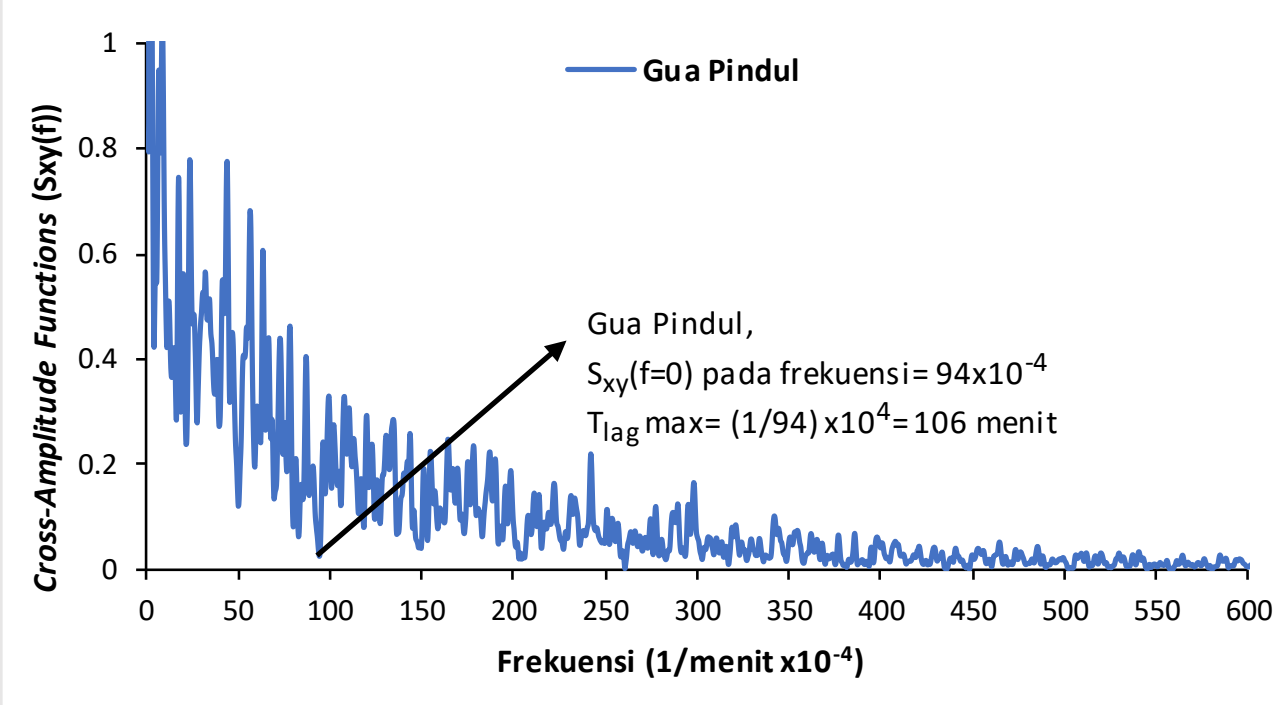

Gambar 4.20. Grafik cross-amplitude Gua Pindul

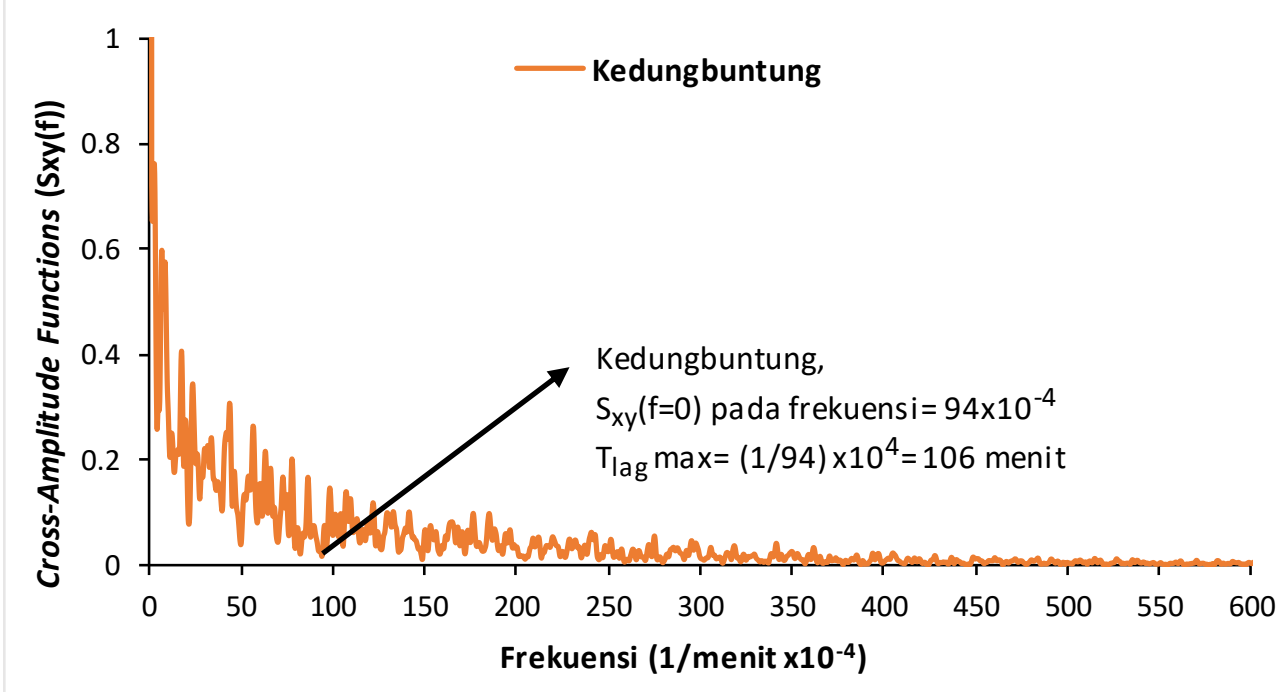

Gambar 4.21. Grafik cross-amplitude Kedungbuntung 


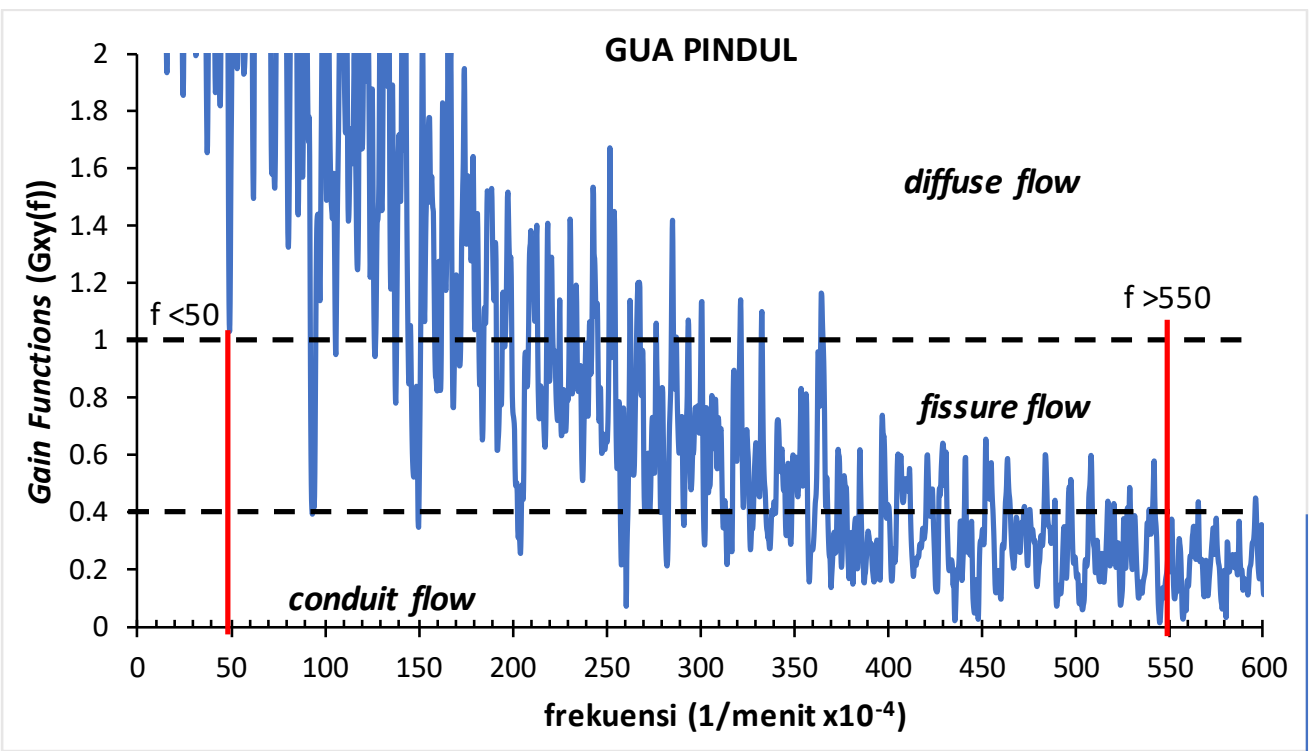

Gambar 4.22. Grafik gain functions Gua Pindul

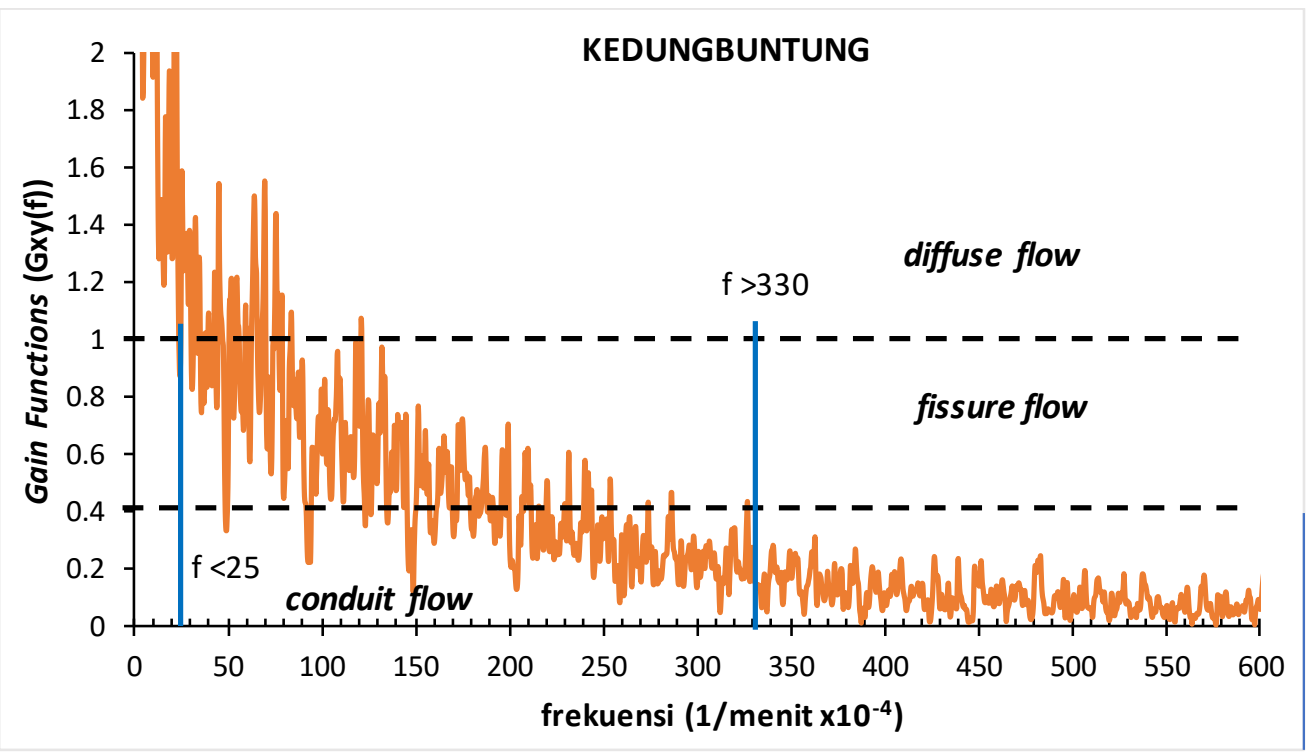

Gambar 4.23. Grafik gain functions Kedungbuntung

\subsubsection{Respons Aliran Fissure}

Respons sistem drainase karst terhadap aliran fissure dihitung berdasarkan rerata durasi pelepasan aliran fissure dan julat durasi pelepasan aliran fissure. Rerata durasi pelepasan aliran fissure dihitung dengan initially sharp decline pada grafik auto-correlation dan cross-correlation yang menggunakan konsep resesi pada grafik hidrograf banjir. Initially sharp decline pada kedua grafik merupakan saat dimana aliran fissure mulai dilepaskan. Gua Pindul dan Kedungbuntung memiliki initially sharp decline yang sama pada grafik cross-correlation dan auto- 
correlation, yaitu sekitar 4 jam (Gambar 4.18 dan 4.24). Hal ini menunjukkan bahwa Gua Pindul dan Kedungbuntung memiliki rerata durasi pelepasan aliran fissure 4 jam.

Sementara itu, julat durasi pelepasan aliran fissure diperoleh melalui perhitungan gain functions. Gain functions $\left(\mathrm{G}_{\mathrm{xy}}\right)$ menunjukkan julat durasi pelepasan aliran fissure ketika grafik menunjukkan nilai $\mathrm{G}_{\mathrm{xy}}>0,4$ dan $\mathrm{G}_{\mathrm{xy}}<1$ atau dapat dituliskan $0,4<\mathrm{G}_{\mathrm{xy}}<1$. Angka ini merupakan nilai yang ditetapkan oleh Padilla dan Pulido-Bosch (1995). Gambar 4.22 menunjukkan Gua Pindul memiliki grafik dengan nilai $0,4<\mathrm{G}_{\mathrm{xy}}<1$ pada frekuensi $50 \times 10^{-4}$ (durasi= $[1 / 50] \times 10^{4}=200$ menit) hingga $550 \times 10^{-4}$ (durasi $=[1 / 550] \times 10^{4}=18$ menit) yang berarti memiliki julat durasi pelepasan aliran fissure 18 menit hingga 3,5 jam. Sementara itu, Kedungbuntung memiliki grafik dengan nilai $0,4<\mathrm{G}_{\mathrm{xy}}<1$ pada frekuensi $13 \times 10^{-4}$ (durasi $=[1 / 25] \times 10^{4}=400$ menit) hingga $330 \times 10^{-4}\left(\right.$ durasi $=[1 / 330] \times 10^{4}=30$ menit $)$ yang berarti memiliki julat durasi 30 menit hingga 6,5 jam (Gambar 4.23).

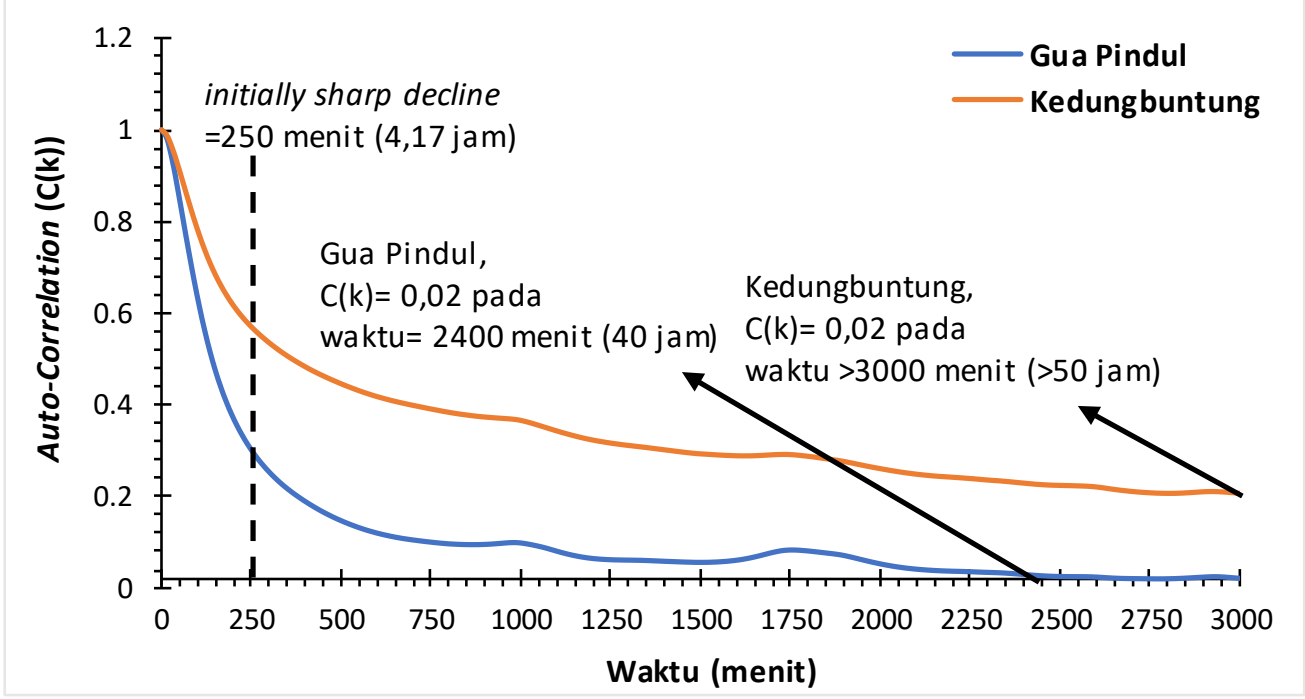

Gambar 4.24. Grafik auto-correlation Gua Pindul dan Kedungbuntung

\subsubsection{Respons Aliran Diffuse}

Respons sistem drainase karst terhadap aliran diffuse dihitung berdasarkan durasi pelepasan aliran diffuse dan durasi minimum pelepasan alirannya. Durasi pelepasan aliran diffuse didapatkan melalui perhitungan auto-correlation dan spectral density functions. Kedua perhitungan tersebut menggunakan konsep resesi 
pada grafik hidrograf banjir. Durasi minimum pelepasan aliran diffuse didapatkan dengan perhitungan gain functions.

Auto-correlation $(\mathrm{C}(\mathrm{k}))$ menunjukkan rerata durasi pelepasan aliran diffuse dari seluruh kejadian banjir yang terjadi. Rerata durasi tersebut diperoleh ketika nilai $\mathrm{C}(\mathrm{k})$ mencapai predetermined value pada grafik auto-correlation. Menurut Zang, dkk (2013), predetermine value dapat dihitung dengan persamaan 18. Hasil perhitungan predetermine value pada penelitian ini adalah 0,02 .

Gua Pindul memiliki $\mathrm{C}(\mathrm{k})$ yang mencapai nilai 0,02 pada waktu 40 jam (Gambar 4.22). Sementara itu, nilai $\mathrm{C}(\mathrm{k})$ Kedungbuntung belum mecapai 0,02 pada waktu maksimal yang ditunjukkan grafik. Hal ini menunjukkan bahwa Gua Pindul memiliki rerata pelepasan aliran diffuse yang lebih cepat (40 jam) dibandingkan Kedungbuntung (>50 jam).

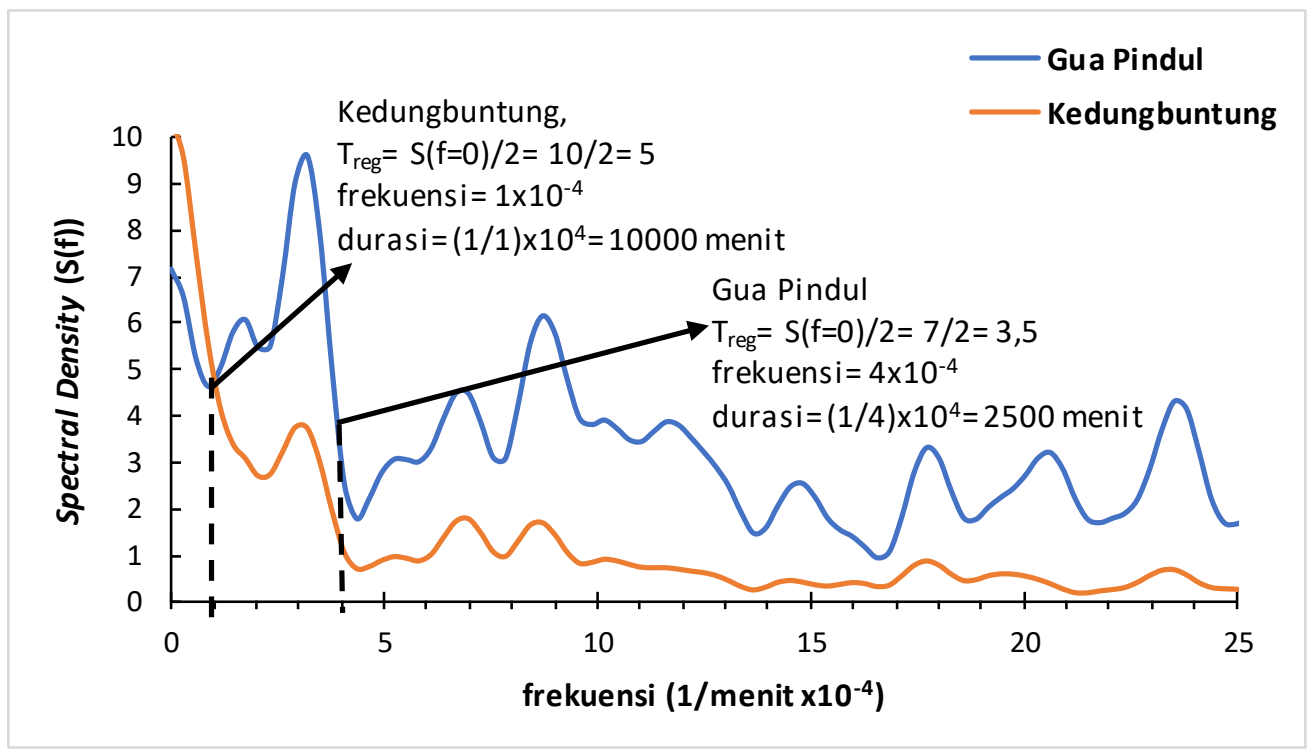

Gambar 4.25. Grafik spectral density Gua Pindul dan Kedungbuntung

Spectral density (S(f)) juga menunjukkan rerata durasi pelepasan aliran diffuse dari seluruh kejadian banjir yang terjadi (durasi penyimpanan input signal oleh sistem drainase karst) (Larocque, 1998). Rerata durasi tersebut diperoleh ketika nilai $\mathrm{S}(\mathrm{f})$ pada grafik spectral density mencapai nilai time regulation $\left(\mathrm{T}_{\mathrm{reg}}\right)$.

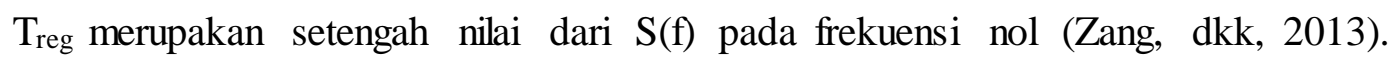
Perhitungan menggunakan persamaan 21 menunjukkan bahwa grafik $\mathrm{S}(\mathrm{f})$ Gua Pindul mencapai $\mathrm{T}_{\text {reg }}$ pada frekuensi $4 \times 10^{-4}$ sedangkan Kedungbuntung pada 
frekuensi $1 \times 10^{-4}$ (Gambar 4.25). Hal tersebut menunjukkan bahwa Gua Pindul memiliki rerata pelepasan aliran diffuse dengan durasi 41 jam 40 menit yang lebih cepat dibandingkan Kedungbuntung yang memiliki durasi 166 jam 40 menit.

Gain functions $\left(\mathrm{G}_{\mathrm{xy}}\right)$ menunjukkan durasi minimum pelepasan aliran diffuse ketika nilai $\mathrm{G}_{\mathrm{xy}}>1$ pada grafik. Angka tersebut merupakan nilai yang ditetapkan oleh Padilla dan Pulido-Bosch (1995). Gua Pindul memiliki grafik gain functions dengan nilai $\mathrm{G}_{\mathrm{xy}}>1$ pada frekuensi $50 \times 10^{-4}$ (durasi= $[1 / 50] \times 10^{4}=3,5 \mathrm{jam}$ ) sedangkan Kedungbuntung pada frekuensi $13 \times 10^{-4}$ (durasi $=[1 / 25] \times 10^{4}=6,5 \mathrm{jam}$ ) (Gambar 4.22 dan 4.23). Hal tersebut memiliki arti bahwa Gua Pindul memiliki durasi minimum pelepasan aliran diffuse dengan waktu $>3,5$ jam yang lebih cepat dibandingkan Kedungbuntung yang memiliki durasi >6,5 jam.

\subsubsection{Variasi Spasial Respons Sistem Drainase Karst Terhadap Curah Hujan}

Perhitungan time series analysis menunjukkan bahwa Gua Pindul dan Kedungbuntung memiliki respons terhadap aliran conduit dan fissure yang sama. Sementara itu, pelepasan aliran diffuse Gua Pindul lebih cepat dibandingkan Kedungbuntung. Meskipun demikian keduanya masih tergolong baik dalam melepaskan aliran diffuse. Respons terhadap aliran conduit ditunjukkan dengan $\mathrm{T}_{\text {lag }}$ maksimum dan durasi maksimum pelepasan aliran conduit. Respons terhadap aliran fissure ditunjukkan oleh julat durasi pelepasan aliran fissure. Respons terhadap aliran diffuse ditunjukkan oleh rerata durasi pelepasan aliran diffuse dan rerata durasi minimumnya.

Tlag maksimum Gua Pindul dan Kedungbuntung memiliki waktu $<1$ jam 46 menit. Nilai $\mathrm{T}_{\text {lag }}$ tersebut ( $<1$ jam 46 menit) memiliki perbedaan dengan nilai $\mathrm{T}_{\mathrm{p}}$ yang dihitung menggunakan hidrograf banjir ( $<2$ jam 42 menit) (Tabel 4.20). Perbedaan ini disebabkan karena perhitungan $\mathrm{T}_{\mathrm{p}}$ dilakukan dengan mengamati grafik hidrograf banjir sedangkan $\mathrm{T}_{\text {lag }}$ dihitung menggunakan metode statistik (time series analysis). Meskipun demikian, $\mathrm{T}_{\text {lag }}$ dan $\mathrm{T}_{\mathrm{p}}$ menunjukkan respons banjir yang cepat karena memiliki nilai yang berselisih kecil dengan rerata durasi hujan (2 jam 24 menit).

Rerata durasi maksimum pelepasan aliran conduit di Gua Pindul memiliki waktu <18 menit yang juga lebih cepat dibandingkan Kedungbuntung yang 
memiliki durasi maksimum <30 menit. Lebih cepatnya pelepasan aliran conduit Gua Pindul tersebut disebabkan karena adanya imbuhan dari sinking stream Kedungbuntung dan sistem perguaan. Sementara itu, Kedungbuntung diimbuh oleh akuifer dengan dominasi retakan diffuse. Meskipun demikian, perbedaan pelepasan aliran conduit tidak begitu besar yaitu hanya 12 menit. Hal ini juga didukung oleh hasil perhitungan konstanta resesi aliran conduit $\left(\mathrm{K}_{\mathrm{c}}\right)$ (Tabel 4.20). Perhitungan $\mathrm{K}_{\mathrm{c}}$ Gua Pindul $\left(\mathrm{K}_{\mathrm{c}}=0,303\right)$ memiliki nilai yang lebih kecil dibandingkan Kedungbuntung $\left(\mathrm{K}_{\mathrm{c}}=0,325\right)$, namun hail uji $t$-test menunjukkan perbedaan ini tidak signifikan (Tabel 4.10).

Perhitungan initially sharp decline pada auto-correlation dan crosscorellation menunjukkan kedua lokasi memiliki rerata durasi pelepasan aliran fissure yang sama (sekitar 4 jam). Analisis berdasarkan frequency base (gain functions) menunjukkan nilai durasi yang berbeda pada kedua lokasi (18 menit 3,5 jam pada Gua Pindul dan 30 menit - 6,5 jam pada Kedungbuntung). Meskipun demikian, perbedaan tersebut tidak signifikan. Hal ini didukung oleh perhitungan konstanta resesi aliran fissure $\left(\mathrm{K}_{\mathrm{i}}\right)$ (Tabel 4.20). Nilai $\mathrm{K}_{\mathrm{i}}$ Gua Pindul $\left(\mathrm{K}_{\mathrm{i}}=0,705\right)$ lebih kecil dibandingkan Kedungbuntung $\left(\mathrm{K}_{\mathrm{i}}=0,760\right)$, namun uji $t$-test menunjukkan perbedaan tersebut tidak signifikan (Tabel 4.10).

Gua Pindul memiliki rerata pelepasan aliran diffuse (41 jam 40 menit) yang lebih cepat dibanding Kedungbuntung (166 jam 40 menit). Hal ini disebabkan karena Gua Pindul mendapat imbuhan dari Sinking Stream Kedungbuntung dan sistem perguaan sedangkan Kedungbuntung diimbuh oleh akuifer dengan dominasi retakan diffuse. Meskipun demikian, durasi keduanya tergolong masih baik dalam melepaskan aliran diffuse. Hal ini didukung oleh konstanta resesi aliran diffuse $\left(\mathrm{K}_{\mathrm{b}}\right)$ yang menunjukkan kedua memiliki nilai >0,98 dan tidak memiliki perbedaan siginifikan (Tabel 4.10 dan 4.20)

Kedua lokasi memiliki durasi minimum pelepasan aliran diffuse yang tergolong cepat (>3,5 jam pada Gua Pindul dan >6,5 jam pada Kedungbuntung). Hal ini disebabkan oleh karakteristik kedua lokasi. Sinking Stream Kedungbuntung merupakan sungai permukaan sedangkan Gua Pindul merupakan outlet system drainase karst yang diimbuh oleh jaringan sungai bawah tanah. 
Tabel 4.20. Hasil perhitungan time series analysis, $\mathrm{T}_{\mathrm{lag}}, \mathrm{T}_{\mathrm{b}}$, dan konstanta resesi di Gua Pindul dan Kedungbuntung

\begin{tabular}{|c|c|c|c|c|c|c|c|c|c|c|c|}
\hline \multirow[t]{2}{*}{ Respons } & \multirow[t]{2}{*}{ Keterangan } & \multirow[t]{2}{*}{ Metode } & \multirow[t]{2}{*}{ Indikator } & \multicolumn{2}{|c|}{ Time series analysis } & \multicolumn{2}{|l|}{${ }^{*} \mathrm{~T}_{\mathrm{p}}$} & \multicolumn{2}{|l|}{${ }^{*} \mathrm{~T}_{\mathrm{b}}$} & \multicolumn{2}{|c|}{ Konstant resesi } \\
\hline & & & & GP (jam) & $\mathrm{KG}$ (jam) & $\begin{array}{l}\text { GP } \\
\text { (jam) }\end{array}$ & $\begin{array}{l}\text { KG } \\
\text { (jam) }\end{array}$ & $\begin{array}{l}\text { GP } \\
\text { (jam) }\end{array}$ & $\begin{array}{l}\text { KG } \\
\text { (jam) }\end{array}$ & GP & KG \\
\hline \multirow[t]{4}{*}{ Conduit } & Rerata $\mathrm{T}_{\text {lag }}$ & Cross-correlation & Time of graphic peak & 1,75 & 1,75 & 2,7 & 2,6 & - & - & 0,303 & 0,325 \\
\hline & & Phase functions & $T_{\text {lag }}=\theta_{x y}(f) / 2 \pi f$ & 1,75 & 1,6 & & & & & & \\
\hline & $\begin{array}{l}\mathrm{T}_{\text {lag }} \\
\text { maksimum }\end{array}$ & Cross-amplitude & {$\left[\mathrm{S}_{\mathrm{xy}}(\mathrm{f})\right]$ tends to be zero } & $<1,77$ & $<1,77$ & & & & & & \\
\hline & $\begin{array}{l}\text { Durasi } \\
\text { maksimum } \\
\text { pelepasan } \\
\text { aliran }\end{array}$ & Gain functions & $\mathrm{G}_{\mathrm{xy}}<0,4$ & $<0,3$ & $<0,5$ & & & & & & \\
\hline \multirow[t]{2}{*}{ Fissure } & Rerata durasi & Auto-correlation & Initially sharp decline & 4,17 & 4,17 & - & - & - & - & 0,705 & 0,76 \\
\hline & & Cross-correlation & Initially sharp decline & 4 & 4 & & & & & & \\
\hline \multirow[t]{3}{*}{ Diffuse } & Rerata durasi & Auto-correlation & $C(k)=0,02$ & 40 & $>50$ & - & - & 14 & 14 & 0,98 & 0,99 \\
\hline & & $\begin{array}{l}\text { Spectral density } \\
\text { functions }\end{array}$ & $T_{\text {reg }}=S(f=0) / 2$ & 41,7 & 166,7 & & & & & & \\
\hline & $\begin{array}{l}\text { Durasi } \\
\text { minimum } \\
\text { pelepasan } \\
\text { aliran }\end{array}$ & Gain functions & $\mathrm{G}_{\mathrm{xy}}>1$ & $>3,5$ & $>6,5$ & & & & & & \\
\hline
\end{tabular}

$G P$ Gua Pindul, $K G$ Kedungbuntung, ${ }^{*} T_{\text {lag }}$ time lag yang dihitung dengan hidrograf banjir, * $T_{b}$ time to baseflow yang dihitung menggunakan hidrograf banjir 


\section{BAB V \\ KESIMPULAN DAN SARAN}

\subsection{Kesimpulan}

1. Sistem Drainase Karst Pindul memiliki sifat aliran yang bersifat campuran (mixed). Sistem karst ini memiliki pelepasan komponen aliran conduit yang cepat $\left(\mathrm{K}_{\mathrm{c}}<0,5\right)$, namun masih mampu menyimpan airtanah dengan baik yang ditunjukkan oleh nilai $\mathrm{K}_{\mathrm{b}}>0,98$ dan PAD bulanan $>95 \%$. Secara spasial, Gua Pindul memiliki pelepasan komponen aliran yang tidak berbeda signifikan dengan Sinking Stream Kedungbuntung. Uji t-test terhadap variabel konstanta resesi dan PAD setiap kejadian banjir menunjukkan kedua lokasi memiliki rerata yang identik. Nilai $K_{c}, K_{i}$, dan $K_{b}$ Gua Pindul $(0,303 ; 0,705$; dan 0,98) tidak jauh berbeda dengan Kedungbuntung (0,325; 0,760; dan 0,99). Selain itu, PAD setiap kejadian banjir di Gua Pindul (42,9\%) juga memiliki selisih yang kecil dengan Kedungbuntung (47,21\%).

2. Sistem Drainase Karst Pindul memiliki perilaku banjir yang cepat, namun masih baik dalam menyimpan airtanah. Hal ini ditunjukkan dengan $T_{p}(2,7$ jam $)$ yang hampir sama dengan durasi hujan (2,4 jam) dan Tb yang panjang (14 jam). Secara temporal, prosentase hujan yang menjadi overlandflow memiliki nilai yang lebih besar pada akhir musim penghujan. Hal ini menunjukkan jenuhnya sistem drainase karst oleh hujan pada awal musim penghujan. Analisis secara parsial menunjukkan bahwa hujan efektif $\left(\mathrm{P}_{\mathrm{e}}\right)$ merupakan karakteristik hujan yang paling berpengaruh terhadap debit puncak $\left(\mathrm{Q}_{\mathrm{p}}\right)$. Sementara itu, tebal, puncak, dan durasi hujan memiliki pengaruh yang kuat apabila dianalisis secara simultan. Secara spasial, uji t-test menunjukkan kedua lokasi memiliki perilaku $\mathrm{T}_{\mathrm{p}}$ dan $\mathrm{T}_{\mathrm{b}}$ yang identik. Sementara itu, $\mathrm{Q}_{\mathrm{p}}$ dan $\mathrm{P}_{\mathrm{e}} \mathrm{Gua}$ Pindul lebih besar dibandingkan Kedungbuntung karena posisinya sebagai outlet sistem karst.

3. Perhitungan time series analysis menunjukkan bahwa Gua Pindul dan Kedungbuntung memiliki respons terhadap aliran conduit dan fissure yang sama. Durasi maksimum pelepasan aliran conduit di Gua Pindul ( $<18$ menit) tidak jauh berbeda dengan Kedungbuntung ( $<30$ menit). Julat durasi pelepasan aliran 
fissure Gua Pindul (18 menit - 3,5 jam) juga tidak jauh berbeda dengan Kedungbuntung (30 menit - 6,5 jam). Sementara itu, pelepasan aliran diffuse Gua Pindul (>3,5 jam) lebih cepat dibandingkan Kedungbuntung (>6,5 jam). Meskipun demikian keduanya masih tergolong baik dalam melepaskan aliran diffuse (rerata 41 jam 40 menit pada Gua Pindul dan 166 jam 40 menit pada Kedungbuntung).

\subsection{Saran}

1. Imbuhan sistem perguaan di Sistem Drainase Karst Pindul perlu dilakukan monitoring secara kontinu. Hal ini dapat dilakukan dengan memasang logger muka air pada Gua Suruh atau Gua Sioyot. Monitoring ini akan melengkapi karakterisasi sistem drainase karst yang pada penelitian ini telah dilakukan di Sinking Stream Kedungbuntung dan Gua Pindul.

2. Karaktersisasi sistem drainase karst perlu membandingkan dua lokasi yang memiliki perbedaan daerah tangkapan air (DTA). Penelitian ini membandingkan Gua Pindul dan Sinking Stream Kedungbuntung yang masih berada dalam satu DTA. Penelitian dengan perbedaan DTA akan memberikan hasil yang lebih bervariasi secara spasial.

3. Penelitian mengenai pemodelan hubungan airtanah dengan sungai permukaan di Sistem Drainase Karst Pindul perlu dilakukan. Penelitian tersebut dapat memprediksi kejadian banjir secara akurat dan mendetail seperti yang telah dilakukan oleh Marechal, dkk (2008, 2009) dan Fleury, dkk (2013) di Sistem Karst Nimes, Prancis. 


\section{DAFTAR PUSTAKA}

Adji, T.N., Sudarmadji., Woro, S. Hendrayana, H., Hariadi, B. 2006. The Distribution of Flood Hydrograph Recession Constant of Bribin River for Gunung Sewu Karst Aquifer Characterization. Dipublikasi ulang dari Gunung Sewu-Indonesian Cave and Karst Journal vol.2, no.2.

Adji, T.N. 2009. Variasi Spasial-Temporal Hidrogeokimia dan Sifat Aliran Untuk Karakterisasi Sistem Karst Dinamis di Sungai Bawah Tanah Bribin, Kabupaten Gunungkidul, DIY. Desertasi. Fakultas Geografi UGM.

Adji, T.N. dan Bahtiar, I.Y. 2016. Rainfall-Discharge Relationship and Karst Flow Components Analysis for Karst Aquifer Characterization in Petoyan Spring, Java, Indonesia. Environmental Earth Sciences, v.75: p.735.

Adji, T.N. dan Cahyadi, A. 2016. Pentingnya Monitoring Parameter-Parameter Hidrograf Dalam Pengelolaan Airtanah di Kawasan Karst. National Workshop: Best Parctice of Sustainable Water Resources Management Based on Ecohydrology Approach, 12-14 Oktober 2016, Yogyakarta.

Agniy, R.F. 2016. Kajian Hidrogeologi Karst Sistem Gua Pindul, Kecamatan Karangmojo, Kabupaten Gunungkidul. Skripsi. Fakultas Geografi UGM.

Atkinson, T.C. 1977. Diffuse Flow and Conduit Flow in Limestone Terrain in The Mendip Hills, Somerset (Great Britain). Journal of Hydrology 35: p.95-110.

Atkinson, T.C. 1985. Present and Future Directions in Karst Hydrogeology. Ann. Soc. Geoi. Belgique 108: 293-296.

Bahtiar, Y.I. 2014. Kajian Respons Debit Mataair Ngeleng Terhadap Curah Hujan untuk Karakterisasi Akuifer Karst. Skripsi. Fakultas Geografi UGM.

Badan Pusat Statistik (BPS). 2016. Gunungkidul Dalam Angka. Gunungkidul: BPS.

Bambang, J dan Junaidi. 2012. Ekonometrika Deret Waktu: Teori dan Aplikasi. Bogor: IPB Pres.

Bemmelen, R.W. Van. 1949. The Geology of Indonesia Vol. 1 A. Government Printing Office: The Hauge.

Bogli, A. 1980. Karst Hydrology and Physical Speleology. Berlin: Springer Berlin Heidelberg.

Chow, V.T. 1959. Open-Channel Hydraulics. United States of America: McGrawHill.

Chow, V.T., Maidment, D.R., Mays, L.W. 1988. Applied Hydrology. United States of America: McGraw-Hill.

Davie, T. 2008. Fundamentals of Hydrology 2th edition. New York: Routledge. 
Ford, D. dan William, P. 1989. Karst Hydrogeology and Geomorphology. Netherlands: Springer.

Fleury, P., Maréchal, J.C., dan Ladouche, B. 2013. Karst flash-flood forecasting in the city of Nîmes (southern France). Engineering Geology, v.164: p.26-35.

Garrison, T. 2011. Essentials of Oceanography $6^{\text {th }}$ edition. USA: Brooks/Cola Cengage Learning.

Gillieson, D. 1996. Caves: Processes, Development, and Management. Oxford: Blackwell Publishers.

Goldscheider, N. dan Drew, D. 2007. Method in Karst Hydrogeology. London: Taylor \& Francis Group.

Gregor, M. 2010. BFI+ 3.0 User's Manual. Slovakia: Hydrooffice.

Haryono, E. dan Adji, T.N. 2004. Pengantar Geomorfologi dan Hidrologi Karst. Yogyakarta: Kelompok Studi Karst Fakultas Geografi UGM.

Haryono, E. dan Day, M. 2004. Landform Differentiation Within the Gunung Kidul Kegel Karst, Java, Indonesia. Journal of Cave and Karst Studies, v.66, no.2: p.62-69.

Haryono, E. 2014. Speleogenesis Gua Pindul dan Sekitarnya. Laporan Penelitian Hibah Fakultas. Fakultas Geografi UGM.

Horton, R.E. 1933. The Role of Infiltration in The Hydrological Cycle. Transactions of the American Geophysical Union, v.14: p.446-460.

IBM. 2016. IBM SPSS Statistics Base 24. Tokyo:

Jemcov, I. dan Petric, M. 2009. Measured Precipitation Vs. Effective Infiltration and Their Influence on The Assessment of Karst Systems Based on Results of The Time Series Analysis. Journal of Hydrology v.379: p.304-314.

Karimi, H., Raeisi, E., Zare, M. 2003. Hydrodynamic Behavior of The Gilan Karst Spring, West of Zagros, Iran. BCRA Cave and Karst Science, vol 30 no.1: p.15-22.

Kovacs, A. dan Sauter, M. 2007. Modelling Karst Hydrodynamics, In: Goldscheider, N. dan Drew, D., Methods in Karst Hyddrogeology, p.201220. London: Taylor \& Francis Group.

Kusumayudha, S.B. 2005. Hidrogeologi Karst dan Geometri Fraktal Daerah Gunungsewu. Yogyakarta: Adicita Karya Nusa.

Larocque, M., Mangin, A., Razack, M., Banton, O. 1998. Contribution of Correlation and Spectral Analyses to The Regional Study of a Large Karst Aquifer (Charente, France). Journal of Hydrology, v.205: p.217-231.

Lyne, V. dan Hollick, M. 1979. Stochastic Time-Variable Rainfall-Runoff Modelling. I.E., Aust., Natl., Conf., Publ., 79/10, pp.89-93. 
Linsley, JR., Kohler,M.A., Paulhus, J.L.H. 1975. Applied Hydrology. New Delhi: Tata McGraw-Hill.

Mangin, A. 1984. Pour une meilleure conaissance des syste'mes hydrologiques a' partir des analyses corre'latoire et spectrale (For a Better Understanding of Hydrological Systems from Correlation and Spectral Analysis). Journal of Hydrology, v.67: p.25-43.

Maréchal, J.C., Ladouche, B. dan Dörfliger, N. 2008 Karst flash flooding in a Mediterranean karst, the example of Fontaine de Nîmes. Engineering Geology, v.99: p.138-146.

Maréchal, J.C., Ladouche, B. dan Dörfliger, N. 2009. Hydrogeological analysis of groundwater contribution to the 6-8 September 2005 flash flood in Nîmes. La Houille Blanche, v.2: p.88-93.

Misqi, M. 2010. Analis is Konstanta Resesi Sungai Bawah Tanah Untuk Karakterisasi Pelepasan Komponen Akuifer Karst (Studi Kasus: Mataair Beton, Sungai Bawah Tanah Seropan, dan Sungai Bawah Tanah Bribin, Kab. Gunungkidul, Provinsi DIY. Skripsi. Fakultas Geografi UGM.

Musadad. 2014. Partisipasi Masyarakat Dusun Gelaran II dalam Pengembangan Wisata di Goa Pindul, Kabupaten Gunungkidul, Yogyakarta. Tesis. Fakultas Geografi UGM.

Nathan, R.J. dan McMahon, T.A. 1990. Evaluation of Automated Techniques for Baseflow and Recession Analysis. Water Resources Research, v.26, no.7: p.1465-1473.

Oktama, R. 2014. Karakterisasi Akuifer Karst Mataair Ngeleng Dengan Pendekatan Variasi Temporal Sifat Aliran dan Hidrogeokimia. Skripsi. Fakultas Geografi UGM.

Padilla, A. dan Pulido-Bosch, A. 1995. Study of Hydrographs of Karstic Aquifers by means of Correlation and Cross-Spectral Analysis. Journal of Hydrology v.168: p.73-89.

Panagopoulos, G. dan Lambrakis, N. 2006. The Contribution of Time Series Analysis to The Study of The Hydrodynamic Characteristics of The Karst Systems: Application on Two Typical Karst Aquifers of Greece (Trifilia, Almyros Crete). Journal of Hydrology v.329 no.3-4: p.368-376.

Raeisi, R. dan Karami, G. 1997. Hydrochemographs of Berghan Karst Spring as Indicators of Aquifer Characteristics. Journal of Cave and Karst Studies v.59, no.3: p.112-118.

Rahaningmas, F.R. 2013. Geologi dan Hubungan Antara Fasies Karbonat dan Jenis Porositas Terhadap Pembentukan Gua Pindul Desa Bejiharjo dan Sekitarnya, Kecamatan Karangmojo, Kabupaten Gunungkidul, Daerah Istimewa Yogyakarta. Skripsi. Teknik Geologi, Fakultas Teknologi Mineral, AKPRIND Yogyakarta. 
Rahnemaei, M., Zare, M., Nematollahi, A.R., Sedghi, H. 2005. Application of Spectral Analysis of Daily Water Level and Spring Discharge Hydrographs Data for Comparing Physical Characteristics of Karstic Aquifers. Journal of Hydrology v.311: p.106-116.

Schulz, E.F. 1976. Problems in Applied Hydrology. Colorado: Water Resources Publication.

Seyhan, E. 1977. Fundamentals of Hydrology. Netherland: Utrecth.

Smart, P.L. dan Hobbes, S.L. 1986. Characteristics of Carbonate Aquifers: A conceptual basis. In Proceedings, Environmental Problem in Karst Terrains and Their Solution. Bowling Green, KY: National Well Water Association, p.1-4.

Smart, C.C. 1988. Artificial Tracer Techniques for The Determination of Structure of Conduit Aquifer. Groundwater Journal, vol. 26, no. 4.

Soewarno. 1991. Hidrologi - Pengukuran dan Pengolahan Data Aliran SungaiHidrometri. Bandung: Penerbit Nova.

Strahler, A. 2011. Introducing Physical Geography $5^{\text {th }}$ edition. USA: John Wiley and Sons.

Sweeting, M.M. 1972. Karst Landforms. London: Macmillan.

Todd, D.K. 1980. Groundwater Hidrology. New York: John Willey and Sons.

White, W.B. 1969. Conceptual Models for Carbonate Aquifers. Ground Water, v.7, no.3.

White, W.B. 1988. Geomorphology and Hydrology of Karst Terrains. New York: Oxford University Press.

White, W.B. 2002. Conceptual Models For Karstic Aquifers. Speleogenesis and Evolution of Karst Aquifers v.1: p.2.

Williams, P.W. 1983. The Role of the Subcutaneous Zone in Karst Hydrology. Journal of Hydrology v.61: p.45-67.

Zhang, Z., Chen, Xi., Chen X., Shi, P. 2013. Quantifying Time Lag of Epikarst Spring Hydrograph Response to Rainfall Using Correlation and Spectral Analysis. Hydrogeology Journal v.21: p.1619-1631. 


\section{LAMPIRAN}

Lampiran 1. Perhitungan konstanta resesi Gua Pindul

Puncak Banjir: 5 Januari 2017 18:15

\begin{tabular}{|c|c|c|c|c|c|c|c|c|c|c|c|}
\hline Waktu & $\begin{array}{c}\mathbf{Q} \\
(\mathbf{L t} / \mathbf{d t})\end{array}$ & $\begin{array}{c}\text { Alpha } \\
\text { Baseflow }\end{array}$ & $\begin{array}{c}\mathbf{K r} \\
\text { Baseflow }\end{array}$ & $\begin{array}{c}Q \\
\text { Baseflow }\end{array}$ & $\begin{array}{c}\text { Q Interflow } \\
+ \text { Streamflow }\end{array}$ & $\begin{array}{c}\text { Alpha } \\
\text { Interflow }\end{array}$ & $\begin{array}{c}\mathbf{K r} \\
\text { Interflow }\end{array}$ & $\begin{array}{c}\mathbf{Q} \\
\text { Interflow }\end{array}$ & $\begin{array}{c}\text { Q } \\
\text { Streamflow }\end{array}$ & $\begin{array}{c}\text { Alpha } \\
\text { Streamflow }\end{array}$ & $\begin{array}{c}\mathbf{K r} \\
\text { Streamflow }\end{array}$ \\
\hline $\begin{array}{ll}5 / 1 / 2017 & 18: 15\end{array}$ & 10.320 & & & 4.452 & 5.867 & & & 4764 & 1103 & & \\
\hline $\begin{array}{ll}5 / 1 / 2017 & 19: 15\end{array}$ & 8.469 & 0,198 & 0,821 & 4.427 & 4.042 & 0,373 & 0,689 & 3242 & 800 & 0,322 & 0,725 \\
\hline $5 / 1 / 2017 \quad 20: 15$ & 6.931 & 0,200 & 0,818 & 4.403 & 2.529 & 0,469 & 0,626 & 2207 & 321 & 0,911 & 0,402 \\
\hline $5 / 1 / 2017 \quad 21: 15$ & 5.973 & 0,149 & 0,862 & 4.378 & 1.595 & 0,461 & 0,631 & 1502 & 93 & 1,241 & 0,289 \\
\hline $5 / 1 / 2017 \quad 22: 15$ & 5.376 & 0,105 & 0,900 & 4.353 & 1.022 & 0,445 & 0,641 & 1022 & 0 & & \\
\hline $5 / 1 / 2017 \quad 23: 15$ & 5.025 & 0,068 & 0,935 & 4.329 & 696 & 0,385 & 0,681 & 696 & 0 & & \\
\hline $6 / 1 / 2017 \quad 0: 15$ & 4.795 & 0,047 & 0,954 & 4.305 & 490 & 0,350 & 0,705 & 490 & 0 & & \\
\hline $6 / 1 / 2017 \quad 1: 15$ & 4.620 & 0,037 & 0,963 & 4.280 & 339 & 0,369 & 0,692 & 339 & 0 & & \\
\hline $6 / 1 / 2017 \quad 2: 15$ & 4.478 & 0,031 & 0,969 & 4.256 & 222 & 0,426 & 0,653 & 222 & 0 & & \\
\hline $6 / 1 / 2017 \quad 3: 15$ & 4.388 & 0,020 & 0,980 & 4.232 & 156 & 0,354 & 0,702 & 156 & 0 & & \\
\hline $6 / 1 / 2017 \quad 4: 15$ & 4.315 & 0,017 & 0,983 & 4.209 & 107 & 0,376 & 0,686 & 107 & 0 & & \\
\hline $6 / 1 / 2017 \quad 5: 15$ & 4.275 & 0,009 & 0,991 & 4.185 & 90 & 0,165 & 0,848 & 90 & 0 & & \\
\hline $6 / 1 / 2017 \quad 6: 15$ & 4.208 & 0,016 & 0,984 & 4.161 & 47 & 0,659 & 0,517 & 47 & 0 & & \\
\hline $6 / 1 / 2017 \quad 7: 15$ & 4.154 & 0,013 & 0,987 & 4.138 & 15 & 1,106 & 0,331 & 15 & 0 & & \\
\hline $6 / 1 / 2017 \quad 8: 15$ & 4.115 & 0,009 & 0,991 & 4.115 & 0 & & & 0 & 0 & & \\
\hline $6 / 1 / 20179: 15$ & 4.092 & 0,006 & 0,994 & 4.092 & - & & & 0 & 0 & & \\
\hline $6 / 1 / 2017 \quad 10: 15$ & 4.057 & 0,008 & 0,992 & 4.057 & - & & & 0 & 0 & & \\
\hline $6 / 1 / 2017 \quad 11: 15$ & 4.042 & 0,004 & 0,996 & 4.042 & - & & & 0 & 0 & & \\
\hline $6 / 1 / 2017 \quad 12: 15$ & 4.027 & 0,004 & 0,996 & 4.027 & - & & & 0 & 0 & & \\
\hline
\end{tabular}


Lampiran 1. Perhitungan konstanta resesi Gua Pindul

Puncak Banjir: 15 Januari 2017 00:00

\begin{tabular}{|c|c|c|c|c|c|c|c|c|c|c|c|}
\hline Date & $Q(\mathbf{L t})$ & $\begin{array}{c}\text { Alpha } \\
\text { Baseflow }\end{array}$ & $\begin{array}{c}\mathbf{K r} \\
\text { Baseflow }\end{array}$ & $\begin{array}{c}\text { Q } \\
\text { Baseflow }\end{array}$ & $\begin{array}{c}\text { Q Interflow } \\
+ \\
\text { Streamflow }\end{array}$ & $\begin{array}{c}\text { Alpha } \\
\text { Interflow }\end{array}$ & $\begin{array}{c}\mathbf{K r} \\
\text { Interflow }\end{array}$ & $\begin{array}{c}Q \\
\text { Interflow }\end{array}$ & $\begin{array}{c}\mathbf{Q} \\
\text { Streamflow }\end{array}$ & $\begin{array}{c}\text { Alpha } \\
\text { Streamflow }\end{array}$ & $\begin{array}{c}\mathbf{K r} \\
\text { Streamflow }\end{array}$ \\
\hline $1 / 15 / 20170: 00$ & 5874 & & & 4506 & 1368 & & & 432 & 936 & & \\
\hline 1/15/2017 1:00 & 5503 & 0,065 & 0,937 & 4481 & 1022 & 0,291 & 0,747 & 366 & 656 & 0,356 & 0,701 \\
\hline $1 / 15 / 2017 \quad 2: 00$ & 5238 & 0,049 & 0,952 & 4455 & 782 & 0,267 & 0,765 & 311 & 472 & 0,330 & 0,719 \\
\hline 1/15/2017 3:00 & 4996 & 0,047 & 0,954 & 4430 & 566 & 0,324 & 0,723 & 263 & 302 & 0,445 & 0,641 \\
\hline $1 / 15 / 2017 \quad 4: 00$ & 4819 & 0,036 & 0,965 & 4405 & 414 & 0,312 & 0,732 & 223 & 190 & 0,462 & 0,630 \\
\hline $1 / 15 / 20175: 00$ & 4707 & 0,024 & 0,977 & 4381 & 326 & 0,238 & 0,789 & 190 & 137 & 0,331 & 0,719 \\
\hline $1 / 15 / 2017 \quad 6: 00$ & 4567 & 0,030 & 0,970 & 4356 & 211 & 0,434 & 0,648 & 161 & 51 & 0,994 & 0,370 \\
\hline $1 / 15 / 2017 \quad 7: 00$ & 4468 & 0,022 & 0,978 & 4332 & 136 & 0,438 & 0,645 & 136 & 0 & & \\
\hline $1 / 15 / 20178: 00$ & 4423 & 0,010 & 0,990 & 4307 & 116 & 0,165 & 0,848 & 116 & 0 & & \\
\hline 1/15/2017 9:00 & 4354 & 0,016 & 0,984 & 4283 & 71 & 0,489 & 0,613 & 71 & 0 & & \\
\hline 1/15/2017 10:00 & 4330 & 0,006 & 0,994 & 4259 & 71 & 0,001 & 0,999 & 71 & 0 & & \\
\hline $1 / 15 / 2017 \quad 11: 00$ & 4310 & 0,005 & 0,995 & 4235 & 75 & $-0,054$ & 1,055 & 75 & 0 & & \\
\hline $1 / 15 / 2017 \quad 12: 00$ & 4278 & 0,007 & 0,993 & 4211 & 67 & 0,114 & 0,892 & 67 & 0 & & \\
\hline 1/15/2017 13:00 & 4246 & 0,007 & 0,993 & 4187 & 59 & 0,128 & 0,879 & 59 & 0 & & \\
\hline 1/15/2017 14:00 & 4183 & 0,015 & 0,985 & 4164 & 19 & & & 19 & 0 & & \\
\hline 1/15/2017 15:00 & 4179 & 0,001 & 0,999 & 4141 & 39 & & & 39 & 0 & & \\
\hline $1 / 15 / 2017 \quad 16: 00$ & 4152 & 0,007 & 0,993 & 4117 & 35 & & & 35 & 0 & & \\
\hline 1/15/2017 17:00 & 4094 & 0,014 & 0,986 & 4094 & 0 & & & 0 & 0 & & \\
\hline 1/15/2017 18:00 & 4071 & 0,006 & 0,994 & 4071 & 0 & & & 0 & 0 & & \\
\hline 1/15/2017 19:00 & 4037 & 0,008 & 0,992 & 4037 & 0 & & & 0 & 0 & & \\
\hline $1 / 15 / 2017 \quad 20: 00$ & 4025 & 0,003 & 0,997 & 4025 & 0 & & & 0 & 0 & & \\
\hline
\end{tabular}




\section{Lampiran 1. Perhitungan konstanta resesi Gua Pindul}

Puncak Banjir: 1 Februari 2017 23:45

\begin{tabular}{|c|c|c|c|c|c|c|c|c|c|c|c|}
\hline Date & $\mathbf{Q}(\mathbf{L t})$ & $\begin{array}{c}\text { Alpha } \\
\text { Baseflow }\end{array}$ & $\begin{array}{c}\mathrm{Kr} \\
\text { Baseflow }\end{array}$ & $\begin{array}{c}\text { Q } \\
\text { Baseflow }\end{array}$ & $\begin{array}{c}\text { Q Interflow } \\
+ \\
\text { Streamflow }\end{array}$ & $\begin{array}{c}\text { Alpha } \\
\text { Interflow }\end{array}$ & $\begin{array}{c}\text { Kr } \\
\text { Interflow }\end{array}$ & $\begin{array}{c}Q \\
\text { Interflow }\end{array}$ & $\begin{array}{c}\text { Q } \\
\text { Streamflow }\end{array}$ & $\begin{array}{c}\text { Alpha } \\
\text { Streamflow }\end{array}$ & $\begin{array}{c}\mathbf{K r} \\
\text { Streamflow }\end{array}$ \\
\hline $2 / 1 / 2017 \quad 23: 45$ & 11132 & & & 4894 & 6238 & & & 3098 & 3140 & & \\
\hline $2 / 2 / 2017 \quad 0: 45$ & 9465 & 0,162 & 0,850 & 4853 & 4612 & 0,302 & 0,739 & 2300 & 2311 & 0,306 & 0,736 \\
\hline $2 / 2 / 2017 \quad 1: 45$ & 7699 & 0,207 & 0,813 & 4813 & 2886 & 0,469 & 0,626 & 1708 & 1178 & 0,674 & 0,510 \\
\hline $2 / 2 / 2017 \quad 2: 45$ & 6698 & 0,139 & 0,870 & 4773 & 1925 & 0,405 & 0,667 & 1268 & 657 & 0,584 & 0,558 \\
\hline $2 / 2 / 2017 \quad 3: 45$ & 6050 & 0,102 & 0,903 & 4734 & 1317 & 0,380 & 0,684 & 942 & 375 & 0,560 & 0,571 \\
\hline $2 / 2 / 2017 \quad 4: 45$ & 5587 & 0,080 & 0,923 & 4694 & 893 & 0,388 & 0,678 & 699 & 194 & 0,660 & 0,517 \\
\hline $2 / 2 / 2017 \quad 5: 45$ & 5230 & 0,066 & 0,936 & 4655 & 575 & 0,440 & 0,644 & 519 & 56 & 1,245 & 0,288 \\
\hline $2 / 2 / 2017 \quad 6: 45$ & 5002 & 0,045 & 0,956 & 4617 & 385 & 0,400 & 0,670 & 385 & 0 & & \\
\hline $2 / 2 / 2017 \quad 7: 45$ & 4865 & 0,028 & 0,973 & 4579 & 286 & 0,298 & 0,743 & 286 & 0 & & \\
\hline $2 / 2 / 2017 \quad 8: 45$ & 4700 & 0,034 & 0,966 & 4541 & 160 & 0,584 & 0,558 & 160 & 0 & & \\
\hline 2/2/2017 9:45 & 4598 & 0,022 & 0,978 & 4503 & 95 & 0,514 & 0,598 & 95 & 0 & & \\
\hline $2 / 2 / 2017 \quad 10: 45$ & 4523 & 0,016 & 0,984 & 4466 & 58 & 0,505 & 0,603 & 58 & 0 & & \\
\hline $2 / 2 / 2017 \quad 11: 45$ & 4465 & 0,013 & 0,987 & 4429 & 37 & 0,448 & 0,639 & 37 & 0 & & \\
\hline 2/2/2017 12:45 & 4392 & 0,017 & 0,984 & 4392 & 0 & & & 0 & 0 & & \\
\hline 2/2/2017 13:45 & 4356 & 0,008 & 0,992 & 4356 & 0 & & & 0 & 0 & & \\
\hline $2 / 2 / 2017 \quad 14: 45$ & 4311 & 0,010 & 0,990 & 4311 & 0 & & & 0 & 0 & & \\
\hline $2 / 2 / 2017 \quad 15: 45$ & 4252 & 0,014 & 0,986 & 4252 & 0 & & & 0 & 0 & & \\
\hline $2 / 2 / 2017 \quad 16: 45$ & 4204 & 0,011 & 0,989 & 4204 & 0 & & & 0 & 0 & & \\
\hline
\end{tabular}


Lampiran 1. Perhitungan konstanta resesi Gua Pindul

Puncak Banjir: 3 Februari 2017 04:30

\begin{tabular}{|c|c|c|c|c|c|c|c|c|c|c|c|}
\hline Date & $\mathbf{Q}(\mathbf{L t})$ & $\begin{array}{c}\text { Alpha } \\
\text { Baseflow }\end{array}$ & $\begin{array}{c}\mathrm{Kr} \\
\text { Baseflow }\end{array}$ & $\begin{array}{c}Q \\
\text { Baseflow }\end{array}$ & $\begin{array}{c}Q \\
\text { Interflow + } \\
\text { Streamflow }\end{array}$ & $\begin{array}{c}\text { Alpha } \\
\text { Interflow }\end{array}$ & $\begin{array}{c}\mathrm{Kr} \\
\text { Interflow }\end{array}$ & $\begin{array}{c}Q \\
\text { Interflow }\end{array}$ & $\begin{array}{c}Q \\
\text { Streamflow }\end{array}$ & $\begin{array}{c}\text { Alpha } \\
\text { Streamflow }\end{array}$ & $\begin{array}{c}\mathbf{K r} \\
\text { Streamflow }\end{array}$ \\
\hline $2 / 3 / 2017 \quad 4: 30$ & 12.867 & & & 4.956 & 7911 & & & 7.165 & 746 & & \\
\hline 2/3/2017 5:30 & 11.595 & 0,104 & 0,901 & 4.910 & 6685 & 0,168 & 0,845 & 4.929 & 1755 & $-0,855$ & 2,352 \\
\hline 2/3/2017 6:30 & 9.020 & 0,251 & 0,778 & 4.865 & 4155 & 0,475 & 0,622 & 3.391 & 764 & 0,832 & 0,435 \\
\hline 2/3/2017 7:30 & 7.385 & 0,200 & 0,819 & 4.820 & 2566 & 0,482 & 0,617 & 2.333 & 232 & 1,190 & 0,304 \\
\hline $2 / 3 / 2017 \quad 9: 30$ & 5.836 & 0,095 & 0,909 & 4.731 & 1104 & 0,396 & 0,673 & 1.104 & 0 & 11,775 & 0,000 \\
\hline $2 / 3 / 2017 \quad 10: 30$ & 5.447 & 0,069 & 0,933 & 4.687 & 760 & 0,374 & 0,688 & 760 & 0 & & \\
\hline $2 / 3 / 2017 \quad 11: 30$ & 5.138 & 0,058 & 0,943 & 4.644 & 494 & 0,430 & 0,650 & 494 & 0 & & \\
\hline $2 / 3 / 2017 \quad 12: 30$ & 4.927 & 0,042 & 0,959 & 4.601 & 326 & 0,418 & 0,659 & 326 & 0 & & \\
\hline 2/3/2017 13:30 & 4.756 & 0,035 & 0,965 & 4.558 & 198 & 0,499 & 0,607 & 198 & 0 & & \\
\hline $2 / 3 / 2017 \quad 15: 30$ & 4.536 & 0,021 & 0,979 & 4.475 & 61 & 0,639 & 0,528 & 61 & 0 & & \\
\hline $2 / 3 / 2017 \quad 16: 30$ & 4.449 & 0,019 & 0,981 & 4.433 & 16 & 1,351 & 0,259 & 16 & 0 & & \\
\hline $2 / 3 / 2017 \quad 17: 30$ & 4.392 & 0,013 & 0,987 & 4.392 & 0 & & & $(0)$ & 0 & & \\
\hline $2 / 3 / 2017 \quad 18: 30$ & 4.360 & 0,007 & 0,993 & 4.352 & 8 & & & 8 & 0 & & \\
\hline $2 / 3 / 2017 \quad 19: 30$ & 4.311 & 0,011 & 0,989 & 4.311 & 0 & & & 0 & 0 & & \\
\hline $2 / 3 / 2017 \quad 20: 30$ & 4.271 & 0,009 & 0,991 & 4.271 & 0 & & & - & 0 & & \\
\hline $2 / 3 / 2017 \quad 21: 30$ & 4.224 & 0,011 & 0,989 & 4.224 & 0 & & & - & 0 & & \\
\hline 2/3/2017 22:30 & 4.177 & 0,011 & 0,989 & 4.177 & 0 & & & - & & & \\
\hline $2 / 3 / 2017 \quad 23: 30$ & 4.154 & 0,006 & 0,994 & 4.154 & 0 & & & - & & & \\
\hline 2/4/2017 $0: 30$ & 4.115 & 0,009 & 0,991 & 4.115 & 0 & & & - & & & \\
\hline 2/4/2017 1:30 & 4.080 & 0,008 & 0,992 & 4.080 & 0 & & & - & & & \\
\hline $2 / 4 / 2017 \quad 2: 30$ & 4.069 & 0,003 & 0,997 & 4.069 & 0 & & & - & & & \\
\hline
\end{tabular}




\section{Lampiran 1. Perhitungan konstanta resesi Gua Pindul}

Puncak Banjir: 15 Februari 2017 00:15

\begin{tabular}{|c|c|c|c|c|c|c|c|c|c|c|c|}
\hline Date & $\mathbf{Q}(\mathbf{L t})$ & $\begin{array}{c}\text { Alpha } \\
\text { Baseflow }\end{array}$ & $\begin{array}{c}\text { Kr } \\
\text { Baseflow }\end{array}$ & $\begin{array}{c}\text { Q } \\
\text { Baseflow }\end{array}$ & $\begin{array}{c}\text { Q Interflow } \\
+ \\
\text { Streamflow }\end{array}$ & $\begin{array}{c}\text { Alpha } \\
\text { Interflow }\end{array}$ & $\begin{array}{c}\mathrm{Kr} \\
\text { Interflow }\end{array}$ & $\begin{array}{c}Q \\
\text { Interflow }\end{array}$ & $\begin{array}{c}\mathbf{Q} \\
\text { Streamflow }\end{array}$ & $\begin{array}{c}\text { Alpha } \\
\text { Streamflow }\end{array}$ & $\begin{array}{c}\mathbf{K r} \\
\text { Streamflow }\end{array}$ \\
\hline 2/15/2017 $0: 15$ & 6.019 & & & 4497 & 1.522 & & & 543 & 979 & & \\
\hline $2 / 15 / 2017 \quad 1: 15$ & 5.607 & 0,071 & 0,931 & 4468 & 1.139 & 0,290 & 0,748 & 396 & 743 & 0,276 & 0,759 \\
\hline $2 / 15 / 2017 \quad 2: 15$ & 5.175 & 0,080 & 0,923 & 4439 & 736 & 0,436 & 0,646 & 289 & 447 & 0,508 & 0,602 \\
\hline $2 / 15 / 2017 \quad 3: 15$ & 4.900 & 0,055 & 0,947 & 4410 & 490 & 0,407 & 0,666 & 211 & 279 & 0,470 & 0,625 \\
\hline $2 / 15 / 2017 \quad 4: 15$ & 4.765 & 0,028 & 0,972 & 4381 & 384 & 0,245 & 0,783 & 154 & 230 & 0,195 & 0,823 \\
\hline $2 / 15 / 2017 \quad 5: 15$ & 4.620 & 0,031 & 0,970 & 4352 & 267 & 0,362 & 0,696 & 112 & 155 & 0,395 & 0,674 \\
\hline $2 / 15 / 2017 \quad 6: 15$ & 4.490 & 0,028 & 0,972 & 4324 & 166 & 0,475 & 0,622 & 82 & 84 & 0,609 & 0,544 \\
\hline $2 / 15 / 2017 \quad 7: 15$ & 4.356 & 0,030 & 0,970 & 4296 & 60 & 1,023 & 0,360 & 60 & 0 & & \\
\hline $2 / 15 / 2017 \quad 8: 15$ & 4.311 & 0,010 & 0,990 & 4268 & 44 & 0,315 & 0,730 & 44 & 0 & & \\
\hline 2/15/2017 9:15 & 4.248 & 0,015 & 0,985 & 4240 & 8 & 1,723 & 0,178 & 8 & 0 & & \\
\hline $2 / 15 / 2017 \quad 10: 15$ & 4.228 & 0,005 & 0,995 & 4212 & 16 & & & 16 & 0 & & \\
\hline $2 / 15 / 2017 \quad 11: 15$ & 4.185 & 0,010 & 0,990 & 4185 & 0 & & & 0 & 0 & & \\
\hline $2 / 15 / 2017 \quad 12: 15$ & 4.157 & 0,007 & 0,993 & 4157 & - & & & - & 0 & & \\
\hline $2 / 15 / 2017 \quad 13: 15$ & 4.123 & 0,008 & 0,992 & 4123 & - & & & - & 0 & & \\
\hline $2 / 15 / 2017 \quad 14: 15$ & 4.057 & 0,016 & 0,984 & 4057 & - & & & - & 0 & & \\
\hline $2 / 15 / 2017 \quad 15: 15$ & 4.031 & 0,007 & 0,993 & 4031 & - & & & - & 0 & & \\
\hline
\end{tabular}




\section{Lampiran 1. Perhitungan konstanta resesi Gua Pindul}

Puncak Banjir: 1 Maret 2017 16:15

\begin{tabular}{|c|c|c|c|c|c|c|c|c|c|c|c|}
\hline Date & $\mathbf{Q}(\mathbf{L t})$ & $\begin{array}{c}\text { Alpha } \\
\text { Baseflow }\end{array}$ & $\begin{array}{c}\mathbf{K r} \\
\text { Baseflow }\end{array}$ & $\begin{array}{c}\mathbf{Q} \\
\text { Baseflow }\end{array}$ & $\begin{array}{c}\text { Q Interflow } \\
+ \\
\text { Streamflow }\end{array}$ & $\begin{array}{c}\text { Alpha } \\
\text { Interflow }\end{array}$ & $\begin{array}{c}\mathbf{K r} \\
\text { Interflow }\end{array}$ & $\begin{array}{c}Q \\
\text { Interflow }\end{array}$ & $\begin{array}{c}\text { Q } \\
\text { Streamflow }\end{array}$ & $\begin{array}{c}\text { Alpha } \\
\text { Streamflow }\end{array}$ & $\begin{array}{c}\mathbf{K r} \\
\text { Streamflow }\end{array}$ \\
\hline $3 / 1 / 2017 \quad 16: 15$ & 30.681 & & & 7.692 & 22.989 & & & 10.829 & 12.160 & & \\
\hline $3 / 1 / 2017 \quad 17: 15$ & 23.633 & 0,261 & 0,770 & 7.389 & 16.244 & 0,347 & 0,707 & 6.787 & 9.457 & 0,251 & 0,778 \\
\hline $3 / 1 / 2017 \quad 18: 15$ & 15.612 & 0,415 & 0,661 & 7.097 & 8.515 & 0,646 & 0,524 & 4.254 & 4.261 & 0,797 & 0,451 \\
\hline 3/1/2017 19:15 & 10.902 & 0,359 & 0,698 & 6.817 & 4.085 & 0,735 & 0,480 & 2.666 & 1.419 & 1,100 & 0,333 \\
\hline 3/1/2017 20:15 & 8.490 & 0,250 & 0,779 & 6.548 & 1.941 & 0,744 & 0,475 & 1.671 & 270 & 1,658 & 0,190 \\
\hline $3 / 1 / 2017 \quad 21: 15$ & 7.337 & 0,146 & 0,864 & 6.290 & 1.047 & 0,617 & 0,540 & 1.047 & 0 & & \\
\hline $3 / 1 / 2017 \quad 22: 15$ & 6.698 & 0,091 & 0,913 & 6.042 & 657 & 0,467 & 0,627 & 657 & - & & \\
\hline 3/1/2017 23:15 & 6.250 & 0,069 & 0,933 & 5.803 & 447 & 0,384 & 0,681 & 447 & - & & \\
\hline $3 / 2 / 2017 \quad 0: 15$ & 5.785 & 0,077 & 0,926 & 5.574 & 211 & 0,750 & 0,472 & 211 & - & & \\
\hline $3 / 2 / 2017 \quad 1: 15$ & 5.433 & 0,063 & 0,939 & 5.354 & 79 & 0,986 & 0,373 & 79 & - & & \\
\hline $3 / 2 / 2017 \quad 2: 15$ & 5.143 & 0,055 & 0,947 & 5.143 & 0 & 13,245 & 0,000 & 0 & - & & \\
\hline $3 / 2 / 2017 \quad 3: 15$ & 4.940 & 0,040 & 0,961 & 4.940 & - & & & - & - & & \\
\hline $3 / 2 / 2017 \quad 4: 15$ & 4.830 & 0,023 & 0,978 & 4.830 & - & & & - & - & & \\
\hline $3 / 2 / 2017 \quad 5: 15$ & 4.687 & 0,030 & 0,971 & 4.687 & - & & & - & - & & \\
\hline $3 / 2 / 2017 \quad 6: 15$ & 4.544 & 0,031 & 0,969 & 4.544 & - & & & - & - & & \\
\hline $3 / 2 / 2017 \quad 7: 15$ & 4.425 & 0,027 & 0,974 & 4.425 & - & & & - & - & & \\
\hline $3 / 2 / 20178: 15$ & 4.352 & 0,017 & 0,984 & 4.352 & - & & & - & - & & \\
\hline $3 / 2 / 2017 \quad 9: 15$ & 4.283 & 0,016 & 0,984 & 4.283 & - & & & - & - & & \\
\hline
\end{tabular}




\section{Lampiran 1. Perhitungan konstanta resesi Gua Pindul}

Puncak Banjir: 5 Maret 2017 15:45

\begin{tabular}{|c|c|c|c|c|c|c|c|c|c|c|c|}
\hline Date & $Q(\mathbf{L t})$ & $\begin{array}{c}\text { Alpha } \\
\text { Baseflow }\end{array}$ & $\begin{array}{c}\mathrm{Kr} \\
\text { Baseflow }\end{array}$ & $\begin{array}{c}Q \\
\text { Baseflow }\end{array}$ & $\begin{array}{c}\mathrm{Q} \\
\text { Interflow + } \\
\text { Streamflow }\end{array}$ & $\begin{array}{c}\text { Alpha } \\
\text { Interflow }\end{array}$ & $\begin{array}{c}\mathrm{Kr} \\
\text { Interflow }\end{array}$ & $\begin{array}{c}Q \\
\text { Interflow }\end{array}$ & $\begin{array}{c}Q \\
\text { Streamflow }\end{array}$ & $\begin{array}{c}\text { Alpha } \\
\text { Streamflow }\end{array}$ & $\begin{array}{c}\mathbf{K r} \\
\text { Streamflow }\end{array}$ \\
\hline $3 / 5 / 2017 \quad 15: 45$ & 15.666 & & & 5.339 & 10.327 & & & 7.932 & 2.395 & & \\
\hline $3 / 5 / 2017 \quad 16: 45$ & 11.923 & 0,273 & 0,761 & 5.237 & 6.687 & 0,435 & 0,647 & 4.729 & 1.957 & 0,202 & 0,817 \\
\hline $3 / 5 / 2017 \quad 17: 45$ & 8.396 & 0,351 & 0,704 & 5.136 & 3.260 & 0,718 & 0,488 & 2.820 & 440 & 1,492 & 0,225 \\
\hline $3 / 5 / 2017 \quad 18: 45$ & 6.788 & 0,213 & 0,809 & 5.037 & 1.751 & 0,621 & 0,537 & 1.681 & 70 & 1,836 & 0,159 \\
\hline $3 / 5 / 2017 \quad 19: 45$ & 5.942 & 0,133 & 0,875 & 4.940 & 1.002 & 0,558 & 0,572 & 1.002 & 0 & & \\
\hline $3 / 5 / 2017 \quad 20: 45$ & 5.442 & 0,088 & 0,916 & 4.845 & 598 & 0,517 & 0,596 & 598 & - & & \\
\hline $3 / 5 / 2017 \quad 21: 45$ & 5.074 & 0,070 & 0,932 & 4.752 & 323 & 0,615 & 0,540 & 323 & - & & \\
\hline $3 / 5 / 2017 \quad 22: 45$ & 4.856 & 0,044 & 0,957 & 4.660 & 196 & 0,499 & 0,607 & 196 & - & & \\
\hline $3 / 5 / 2017 \quad 23: 45$ & 4.730 & 0,026 & 0,974 & 4.570 & 160 & 0,204 & 0,816 & 160 & - & & \\
\hline $3 / 6 / 2017 \quad 0: 45$ & 4.557 & 0,037 & 0,963 & 4.482 & 74 & 0,767 & 0,465 & 74 & - & & \\
\hline $3 / 6 / 2017 \quad 1: 45$ & 4.396 & 0,036 & 0,965 & 4.396 & 0 & & & 0 & - & & \\
\hline $3 / 6 / 2017 \quad 2: 45$ & 4.311 & 0,019 & 0,981 & 4.311 & - & & & - & - & & \\
\hline $3 / 6 / 2017 \quad 3: 45$ & 4.240 & 0,017 & 0,983 & 4.240 & - & & & - & - & & \\
\hline $3 / 6 / 2017 \quad 4: 45$ & 4.177 & 0,015 & 0,985 & 4.177 & - & & & - & - & & \\
\hline $3 / 6 / 2017 \quad 5: 45$ & 4.138 & 0,009 & 0,991 & 4.138 & - & & & - & - & & \\
\hline $3 / 6 / 2017 \quad 6: 45$ & 4.061 & 0,019 & 0,981 & 4.061 & - & & & - & - & & \\
\hline $3 / 6 / 2017 \quad 7: 45$ & 4.053 & 0,002 & 0,998 & 4.053 & - & & & - & - & & \\
\hline $3 / 6 / 2017 \quad 8: 45$ & 4.034 & 0,005 & 0,995 & 4.034 & - & & & - & - & & \\
\hline
\end{tabular}


Lampiran 1. Perhitungan konstanta resesi Gua Pindul

Puncak Banjir: 16 Maret 2017 19:15

\begin{tabular}{|c|c|c|c|c|c|c|c|c|c|c|c|}
\hline Date & $Q(\mathbf{L t})$ & $\begin{array}{c}\text { Alpha } \\
\text { Baseflow }\end{array}$ & $\begin{array}{c}\mathrm{Kr} \\
\text { Baseflow }\end{array}$ & $\begin{array}{c}Q \\
\text { Baseflow }\end{array}$ & $\begin{array}{c}\text { Q Interflow } \\
+ \\
\text { Streamflow }\end{array}$ & $\begin{array}{c}\text { Alpha } \\
\text { Interflow }\end{array}$ & $\begin{array}{c}\mathrm{Kr} \\
\text { Interflow }\end{array}$ & $\begin{array}{c}Q \\
\text { Interflow }\end{array}$ & $\begin{array}{c}\text { Q } \\
\text { Streamflow }\end{array}$ & $\begin{array}{c}\text { Alpha } \\
\text { Streamflow }\end{array}$ & $\begin{array}{c}\mathbf{K r} \\
\text { Streamflow }\end{array}$ \\
\hline 3/16/2017 19:15 & 10.886 & & & 4.755 & 6.131 & & & 5.111 & 1.020 & & \\
\hline $3 / 16 / 2017 \quad 20: 15$ & 8.999 & 0,190 & 0,827 & 4.706 & 4.292 & 0,357 & 0,700 & 3.322 & 971 & 0,050 & 0,951 \\
\hline $3 / 16 / 2017 \quad 21: 15$ & 7.111 & 0,235 & 0,790 & 4.658 & 2.453 & 0,560 & 0,571 & 2.159 & 294 & 1,195 & 0,303 \\
\hline $3 / 16 / 2017 \quad 22: 15$ & 6.014 & 0,168 & 0,846 & 4.611 & 1.403 & 0,558 & 0,572 & 1.403 & 0 & & \\
\hline $3 / 16 / 2017 \quad 23: 15$ & 5.476 & 0,094 & 0,911 & 4.564 & 912 & 0,431 & 0,650 & 912 & - & & \\
\hline $3 / 17 / 2017 \quad 0: 15$ & 5.097 & 0,072 & 0,931 & 4.517 & 580 & 0,453 & 0,636 & 580 & - & & \\
\hline $3 / 17 / 2017 \quad 1: 15$ & 4.830 & 0,054 & 0,948 & 4.471 & 359 & 0,481 & 0,618 & 359 & - & & \\
\hline $3 / 17 / 2017 \quad 2: 15$ & 4.649 & 0,038 & 0,963 & 4.426 & 224 & 0,473 & 0,623 & 224 & - & & \\
\hline $3 / 17 / 2017 \quad 3: 15$ & 4.519 & 0,028 & 0,972 & 4.380 & 139 & 0,477 & 0,620 & 139 & - & & \\
\hline $3 / 17 / 2017 \quad 4: 15$ & 4.412 & 0,024 & 0,976 & 4.336 & 77 & 0,595 & 0,552 & 77 & - & & \\
\hline $3 / 17 / 2017 \quad 5: 15$ & 4.311 & 0,023 & 0,977 & 4.292 & 20 & 1,349 & 0,260 & 20 & - & & \\
\hline $3 / 17 / 2017 \quad 6: 15$ & 4.248 & 0,015 & 0,985 & 4.248 & 0 & & & 0 & - & & \\
\hline $3 / 17 / 2017 \quad 7: 15$ & 4.204 & 0,010 & 0,990 & 4.204 & - & & & - & - & & \\
\hline $3 / 17 / 2017 \quad 8: 15$ & 4.142 & 0,015 & 0,985 & 4.142 & - & & & - & - & & \\
\hline $3 / 17 / 20179: 15$ & 4.096 & 0,011 & 0,989 & 4.096 & - & & & - & - & & \\
\hline $3 / 17 / 2017 \quad 10: 15$ & 4.034 & 0,015 & 0,985 & 4.034 & - & & & - & - & & \\
\hline
\end{tabular}




\section{Lampiran 1. Perhitungan konstanta resesi Gua Pindul}

Puncak Banjir: 26 Maret 2017 05:00

\begin{tabular}{|c|c|c|c|c|c|c|c|c|c|c|c|}
\hline Date & $\mathbf{Q}(\mathbf{L t})$ & $\begin{array}{c}\text { Alpha } \\
\text { Baseflow }\end{array}$ & $\begin{array}{c}\text { Kr } \\
\text { Baseflow }\end{array}$ & $\begin{array}{c}\text { Q } \\
\text { Baseflow }\end{array}$ & $\begin{array}{c}\text { Q Interflow } \\
+ \text { Streamflow }\end{array}$ & $\begin{array}{c}\text { Alpha } \\
\text { Interflow }\end{array}$ & $\begin{array}{c}\mathbf{K r} \\
\text { Interflow }\end{array}$ & $\begin{array}{c}\mathbf{Q} \\
\text { Interflow }\end{array}$ & $\begin{array}{c}\text { Q } \\
\text { Streamflow }\end{array}$ & $\begin{array}{c}\text { Alpha } \\
\text { Streamflow }\end{array}$ & $\begin{array}{c}\mathbf{K r} \\
\text { Streamflow }\end{array}$ \\
\hline $3 / 26 / 20175: 00$ & 7.006 & & & 5.313 & 1.693 & & & 693 & 1.000 & & \\
\hline $3 / 26 / 20176: 00$ & 6.250 & 0,114 & 0,892 & 5.206 & 1.044 & 0,484 & 0,617 & 518 & 525 & 0,644 & 0,525 \\
\hline $3 / 26 / 2017 \quad 7: 00$ & 5.681 & 0,096 & 0,909 & 5.102 & 579 & 0,589 & 0,555 & 388 & 191 & 1,010 & 0,364 \\
\hline $3 / 26 / 20178: 00$ & 5.404 & 0,050 & 0,951 & 4.999 & 405 & 0,357 & 0,700 & 290 & 115 & 0,507 & 0,602 \\
\hline $3 / 26 / 20179: 00$ & 5.115 & 0,055 & 0,947 & 4.898 & 217 & 0,624 & 0,536 & 217 & 0 & & \\
\hline $3 / 26 / 2017 \quad 10: 00$ & 4.962 & 0,030 & 0,970 & 4.800 & 163 & 0,290 & 0,748 & 163 & - & & \\
\hline $3 / 26 / 2017 \quad 11: 00$ & 4.799 & 0,033 & 0,967 & 4.703 & 96 & 0,522 & 0,593 & 96 & - & & \\
\hline $3 / 26 / 2017 \quad 12: 00$ & 4.830 & $-0,006$ & 1,006 & 4.608 & 222 & $-0,832$ & 2,298 & 222 & - & & \\
\hline 3/26/2017 13:00 & 4.548 & 0,060 & 0,942 & 4.515 & 33 & 1,910 & 0,148 & 33 & - & & \\
\hline $3 / 26 / 2017 \quad 14: 00$ & 4.425 & 0,028 & 0,973 & 4.425 & 0 & & & 0 & - & & \\
\hline $3 / 26 / 2017 \quad 15: 00$ & 4.335 & 0,020 & 0,980 & 4.335 & - & & & - & - & & \\
\hline $3 / 26 / 2017 \quad 16: 00$ & 4.283 & 0,012 & 0,988 & 4.283 & - & & & - & - & & \\
\hline $3 / 26 / 2017 \quad 17: 00$ & 4.212 & 0,017 & 0,983 & 4.212 & - & & & - & - & & \\
\hline 3/26/2017 18:00 & 4.150 & 0,015 & 0,985 & 4.150 & - & & & - & - & & \\
\hline
\end{tabular}




\section{Lampiran 1. Perhitungan konstanta resesi Gua Pindul}

Puncak Banjir: 31 Maret 2017 17:00

\begin{tabular}{|c|c|c|c|c|c|c|c|c|c|c|c|}
\hline Date & $Q(\mathbf{L t})$ & $\begin{array}{c}\text { Alpha } \\
\text { Baseflow }\end{array}$ & $\begin{array}{c}\text { Kr } \\
\text { Baseflow }\end{array}$ & $\begin{array}{c}\text { Q } \\
\text { Baseflow }\end{array}$ & $\begin{array}{c}\text { Q Interflow } \\
+ \\
\text { Streamflow }\end{array}$ & $\begin{array}{c}\text { Alpha } \\
\text { Interflow }\end{array}$ & $\begin{array}{c}\mathrm{Kr} \\
\text { Interflow }\end{array}$ & $\begin{array}{c}\mathrm{Q} \\
\text { Interflow }\end{array}$ & $\begin{array}{c}\text { Q } \\
\text { Streamflow }\end{array}$ & $\begin{array}{c}\text { Alpha } \\
\text { Streamflow }\end{array}$ & $\begin{array}{c}\mathbf{K r} \\
\text { Streamflow }\end{array}$ \\
\hline 3/31/2017 17:00 & 13.213 & & & 7.220 & 5.993 & & & 2.150 & 3.843 & & \\
\hline $3 / 31 / 2017 \quad 18: 00$ & 11.017 & 0,182 & 0,834 & 6.931 & 4.086 & 0,383 & 0,682 & 1.661 & 2.425 & 0,461 & 0,631 \\
\hline 3/31/2017 19:00 & 8.666 & 0,240 & 0,787 & 6.653 & 2.013 & 0,708 & 0,493 & 1.284 & 729 & 1,201 & 0,301 \\
\hline $3 / 31 / 2017 \quad 20: 00$ & 7.422 & 0,155 & 0,856 & 6.386 & 1.036 & 0,664 & 0,515 & 992 & 44 & 2,815 & 0,060 \\
\hline $3 / 31 / 2017 \quad 21: 00$ & 6.897 & 0,073 & 0,929 & 6.130 & 767 & 0,301 & 0,740 & 767 & 0 & & \\
\hline $3 / 31 / 2017 \quad 22: 00$ & 6.477 & 0,063 & 0,939 & 5.884 & 593 & 0,258 & 0,773 & 593 & - & & \\
\hline 3/31/2017 23:00 & 6.035 & 0,071 & 0,932 & 5.648 & 387 & 0,426 & 0,653 & 387 & - & & \\
\hline 4/1/2017 $0: 00$ & 5.592 & 0,076 & 0,927 & 5.421 & 171 & 0,818 & 0,441 & 171 & - & & \\
\hline $4 / 1 / 2017 \quad 1: 00$ & 5.305 & 0,053 & 0,949 & 5.204 & 101 & 0,525 & 0,591 & 101 & - & & \\
\hline $4 / 1 / 2017 \quad 2: 00$ & 5.097 & 0,040 & 0,961 & 4.995 & 102 & & & 102 & - & & \\
\hline $4 / 1 / 20173: 00$ & 4.795 & 0,061 & 0,941 & 4.795 & 0 & & & 0 & - & & \\
\hline $4 / 1 / 2017 \quad 4: 00$ & 4.603 & 0,041 & 0,960 & 4.603 & - & & & - & - & & \\
\hline 4/1/2017 5:00 & 4.490 & 0,025 & 0,976 & 4.490 & - & & & - & - & & \\
\hline 4/1/2017 6:00 & 4.396 & 0,021 & 0,979 & 4.396 & - & & & - & - & & \\
\hline 4/1/2017 7:00 & 4.279 & 0,027 & 0,973 & 4.279 & - & & & - & - & & \\
\hline 4/1/2017 8:00 & 4.260 & 0,005 & 0,995 & 4.260 & - & & & - & - & & \\
\hline 4/1/2017 9:00 & 4.189 & 0,017 & 0,983 & 4.189 & - & & & - & - & & \\
\hline 4/1/2017 10:00 & 4.123 & 0,016 & 0,984 & 4.123 & - & & & - & - & & \\
\hline
\end{tabular}




\section{Lampiran 1. Perhitungan konstanta resesi Gua Pindul}

Puncak Banjir: 26 April 2017 21:00

\begin{tabular}{|c|c|c|c|c|c|c|c|c|c|c|c|}
\hline Date & $\mathbf{Q}(\mathbf{L t})$ & $\begin{array}{c}\text { Alpha } \\
\text { Baseflow }\end{array}$ & $\begin{array}{c}\mathbf{K r} \\
\text { Baseflow }\end{array}$ & $\begin{array}{c}\text { Q } \\
\text { Baseflow }\end{array}$ & $\begin{array}{c}\mathbf{Q} \\
\text { Interflow + } \\
\text { Streamflow }\end{array}$ & $\begin{array}{c}\text { Alpha } \\
\text { Interflow }\end{array}$ & $\begin{array}{c}\mathbf{K r} \\
\text { Interflow }\end{array}$ & $\begin{array}{c}Q \\
\text { Interflow }\end{array}$ & $\begin{array}{c}\text { Q } \\
\text { Streamflow }\end{array}$ & $\begin{array}{c}\text { Alpha } \\
\text { Streamflow }\end{array}$ & $\begin{array}{c}\mathbf{K r} \\
\text { Streamflow }\end{array}$ \\
\hline 4/26/2017 21:00 & 12.647 & & & 4.784 & 7.863 & & & 7.018 & 845 & & \\
\hline 4/26/2017 22:00 & 10.453 & 0,190 & 0,827 & 4.744 & 5.709 & 0,320 & 0,726 & 4.575 & 1.135 & $-0,295$ & 1,343 \\
\hline 4/26/2017 23:00 & 8.113 & 0,253 & 0,776 & 4.704 & 3.408 & 0,516 & 0,597 & 2.982 & 426 & 0,978 & 0,376 \\
\hline $4 / 27 / 2017 \quad 0: 00$ & 6.771 & 0,181 & 0,835 & 4.665 & 2.106 & 0,481 & 0,618 & 1.944 & 162 & 0,966 & 0,381 \\
\hline 4/27/2017 1:00 & 5.907 & 0,137 & 0,872 & 4.626 & 1.280 & 0,498 & 0,608 & 1.267 & 13 & 2,514 & 0,081 \\
\hline $4 / 27 / 2017 \quad 2: 00$ & 5.414 & 0,087 & 0,917 & 4.588 & 826 & 0,438 & 0,645 & 826 & 0 & & \\
\hline 4/27/2017 3:00 & 5.088 & 0,062 & 0,940 & 4.550 & 538 & 0,428 & 0,652 & 538 & - & & \\
\hline $4 / 27 / 2017 \quad 4: 00$ & 4.852 & 0,048 & 0,954 & 4.512 & 340 & 0,460 & 0,631 & 340 & - & & \\
\hline $4 / 27 / 2017 \quad 5: 00$ & 4.687 & 0,034 & 0,966 & 4.474 & 213 & 0,467 & 0,627 & 213 & - & & \\
\hline 4/27/2017 7:00 & 4.470 & 0,022 & 0,978 & 4.400 & 69 & & & 69 & - & & \\
\hline $4 / 27 / 20178: 00$ & 4.400 & 0,016 & 0,984 & 4.364 & 36 & & & 36 & - & & \\
\hline 4/27/2017 9:00 & 4.327 & 0,017 & 0,983 & 4.327 & 0 & & & 0 & & & \\
\hline 4/27/2017 10:00 & 4.291 & 0,008 & 0,992 & 4.291 & - & & & - & & & \\
\hline 4/27/2017 11:00 & 4.264 & 0,007 & 0,994 & 4.264 & - & & & - & & & \\
\hline 4/27/2017 12:00 & 4.232 & 0,007 & 0,993 & 4.232 & - & & & - & & & \\
\hline 4/27/2017 13:00 & 4.173 & 0,014 & 0,986 & 4.173 & - & & & - & & & \\
\hline 4/27/2017 14:00 & 4.119 & 0,013 & 0,987 & 4.119 & - & & & - & & & \\
\hline 4/27/2017 15:00 & 4.099 & 0,005 & 0,995 & 4.099 & - & & & - & & & \\
\hline
\end{tabular}


Lampiran 2. Perhitungan konstanta resesi Sinking Stream Kedungbuntung

Puncak Banjir 5 Januari 2017 18:15

\begin{tabular}{|c|c|c|c|c|c|c|c|c|c|c|c|}
\hline Date & $\mathbf{Q}(\mathbf{L t})$ & $\begin{array}{c}\text { Alpha } \\
\text { Baseflow }\end{array}$ & $\begin{array}{c}\mathbf{K r} \\
\text { Baseflow }\end{array}$ & Q Baseflow & $\begin{array}{l}\text { Q Interflow + } \\
\text { Streamflow }\end{array}$ & $\begin{array}{c}\text { Alpha } \\
\text { Interflow }\end{array}$ & $\begin{array}{c}\mathbf{K r} \\
\text { Interflow }\end{array}$ & $\begin{array}{c}\mathbf{Q} \\
\text { Interflow }\end{array}$ & $\begin{array}{c}\text { Q } \\
\text { Streamflow }\end{array}$ & $\begin{array}{c}\text { Alpha } \\
\text { Streamflow }\end{array}$ & $\begin{array}{c}\mathbf{K r} \\
\text { Streamflow }\end{array}$ \\
\hline 1/5/2017 18:15 & 4.626 & & & 2.771 & 1.855 & & & 1.276 & 579 & & \\
\hline 1/5/2017 19:15 & 3.772 & 0,204 & 0,816 & 2.752 & 1.020 & 0,598 & 0,550 & 906 & 115 & 1,618 & 0,198 \\
\hline 1/5/2017 20:15 & 3.440 & 0,092 & 0,912 & 2.733 & 707 & 0,366 & 0,693 & 643 & 65 & 0,576 & 0,562 \\
\hline $1 / 5 / 2017 \quad 21: 15$ & 3.191 & 0,075 & 0,928 & 2.714 & 477 & 0,393 & 0,675 & 456 & 21 & 1,118 & 0,327 \\
\hline $1 / 5 / 2017 \quad 22: 15$ & 3.019 & 0,056 & 0,946 & 2.695 & 324 & 0,388 & 0,678 & 324 & 0 & & \\
\hline $1 / 5 / 2017 \quad 23: 15$ & 2.906 & 0,038 & 0,963 & 2.677 & 230 & 0,343 & 0,710 & 230 & - & & \\
\hline $1 / 6 / 2017 \quad 0: 15$ & 2.841 & 0,023 & 0,978 & 2.658 & 183 & 0,227 & 0,797 & 183 & - & & \\
\hline $1 / 6 / 2017 \quad 1: 15$ & 2.761 & 0,029 & 0,972 & 2.640 & 121 & 0,412 & 0,662 & 121 & - & & \\
\hline $1 / 6 / 2017 \quad 2: 15$ & 2.696 & 0,024 & 0,976 & 2.621 & 74 & 0,491 & 0,612 & 74 & - & & \\
\hline $1 / 6 / 2017 \quad 3: 15$ & 2.655 & 0,015 & 0,985 & 2.603 & 52 & 0,354 & 0,702 & 52 & - & & \\
\hline $1 / 6 / 2017 \quad 4: 15$ & 2.620 & 0,013 & 0,987 & 2.585 & 35 & 0,401 & 0,670 & 35 & - & & \\
\hline $1 / 6 / 2017 \quad 5: 15$ & 2.615 & 0,002 & 0,998 & 2.567 & 48 & & & 48 & - & & \\
\hline $1 / 6 / 2017 \quad 6: 15$ & 2.550 & 0,025 & 0,975 & 2.550 & 0 & & & 0 & - & & \\
\hline $1 / 6 / 2017 \quad 7: 15$ & 2.532 & 0,007 & 0,993 & 2.532 & - & & & - & - & & \\
\hline $1 / 6 / 20178: 15$ & 2.519 & 0,005 & 0,995 & 2.519 & - & & & - & - & & \\
\hline 1/6/2017 9:15 & 2.476 & 0,017 & 0,983 & 2.476 & - & & & - & - & & \\
\hline 1/6/2017 10:15 & 2.466 & 0,004 & 0,996 & 2.466 & - & & & - & - & & \\
\hline 1/6/2017 11:15 & 2.469 & $-0,001$ & 1,001 & 2.469 & - & & & - & - & & \\
\hline $1 / 6 / 2017 \quad 12: 15$ & 2.464 & 0,002 & 0,998 & 2.464 & - & & & - & - & & \\
\hline
\end{tabular}


Lampiran 2. Perhitungan konstanta resesi Sinking Stream Kedungbuntung

Puncak Banjir 15 Januari 2017 00:00

\begin{tabular}{|c|c|c|c|c|c|c|c|c|c|c|c|}
\hline Date & $\mathbf{Q}(\mathbf{L t})$ & $\begin{array}{c}\text { Alpha } \\
\text { Baseflow }\end{array}$ & $\begin{array}{c}\mathbf{K r} \\
\text { Baseflow }\end{array}$ & $\begin{array}{c}\text { Q } \\
\text { Baseflow }\end{array}$ & $\begin{array}{c}\text { Q Interflow } \\
+ \\
\text { Streamflow }\end{array}$ & $\begin{array}{c}\text { Alpha } \\
\text { Interflow }\end{array}$ & $\begin{array}{c}\mathbf{K r} \\
\text { Interflow }\end{array}$ & $\begin{array}{c}Q \\
\text { Interflow }\end{array}$ & $\begin{array}{c}\text { Q } \\
\text { Streamflow }\end{array}$ & $\begin{array}{c}\text { Alpha } \\
\text { Streamflow }\end{array}$ & Kr Streamflow \\
\hline $1 / 15 / 2017 \quad 0: 00$ & 3.341 & & & 2.616 & 725 & & & 654 & 71 & & \\
\hline $1 / 15 / 2017 \quad 1: 00$ & 3.154 & 0,058 & 0,944 & 2.603 & 551 & 0,274 & 0,760 & 496 & 55 & 0,262 & 0,769 \\
\hline $1 / 15 / 2017 \quad 2: 00$ & 3.014 & 0,045 & 0,956 & 2.590 & 424 & 0,261 & 0,770 & 377 & 47 & 0,143 & 0,867 \\
\hline $1 / 15 / 20173: 00$ & 2.881 & 0,045 & 0,956 & 2.577 & 305 & 0,331 & 0,718 & 286 & 18 & 0,944 & 0,389 \\
\hline $1 / 15 / 2017 \quad 4: 00$ & 2.781 & 0,035 & 0,965 & 2.564 & 217 & 0,337 & 0,714 & 217 & 0 & & \\
\hline $1 / 15 / 2017 \quad 5: 00$ & 2.716 & 0,024 & 0,977 & 2.551 & 165 & 0,275 & 0,759 & 165 & - & & \\
\hline $1 / 15 / 2017 \quad 6: 00$ & 2.633 & 0,031 & 0,969 & 2.538 & 95 & 0,552 & 0,576 & 95 & - & & \\
\hline $1 / 15 / 2017 \quad 7: 00$ & 2.572 & 0,023 & 0,977 & 2.525 & 48 & 0,694 & 0,500 & 48 & - & & \\
\hline $1 / 15 / 2017 \quad 8: 00$ & 2.545 & 0,011 & 0,989 & 2.512 & 33 & 0,377 & 0,686 & 33 & - & & \\
\hline $1 / 15 / 20179: 00$ & 2.502 & 0,017 & 0,983 & 2.499 & 2 & & & 2 & - & & \\
\hline 1/15/2017 10:00 & 2.486 & 0,006 & 0,994 & 2.486 & 0 & & & 0 & - & & \\
\hline 1/15/2017 11:00 & 2.474 & 0,005 & 0,995 & 2.474 & - & & & - & - & & \\
\hline 1/15/2017 12:00 & 2.454 & 0,008 & 0,992 & 2.454 & - & & & - & - & & \\
\hline 1/15/2017 13:00 & 2.433 & 0,008 & 0,992 & 2.433 & - & & & - & - & & \\
\hline $1 / 15 / 2017 \quad 14: 00$ & 2.393 & 0,017 & 0,983 & 2.393 & - & & & - & - & & \\
\hline 1/15/2017 15:00 & 2.390 & 0,001 & 0,999 & 2.390 & - & & & - & - & & \\
\hline 1/15/2017 16:00 & 2.373 & 0,007 & 0,993 & 2.373 & - & & & - & - & & \\
\hline
\end{tabular}


Lampiran 2. Perhitungan konstanta resesi Sinking Stream Kedungbuntung

Puncak Banjir 1 Februari 2017 23:45

\begin{tabular}{|c|c|c|c|c|c|c|c|c|c|c|c|}
\hline Date & $\begin{array}{c}\mathbf{Q} \\
(\mathbf{L t})\end{array}$ & $\begin{array}{c}\text { Alpha } \\
\text { Baseflow }\end{array}$ & $\begin{array}{c}\mathrm{Kr} \\
\text { Baseflow }\end{array}$ & $\begin{array}{c}\mathbf{Q} \\
\text { Baseflow }\end{array}$ & $\begin{array}{c}\mathrm{Q} \\
\text { Interflow + } \\
\text { Streamflow }\end{array}$ & $\begin{array}{c}\text { Alpha } \\
\text { Interflow }\end{array}$ & $\begin{array}{c}\mathrm{Kr} \\
\text { Interflow }\end{array}$ & $\begin{array}{c}Q \\
\text { Interflow }\end{array}$ & $\begin{array}{c}\text { Q } \\
\text { Streamflow }\end{array}$ & $\begin{array}{c}\text { Alpha } \\
\text { Streamflow }\end{array}$ & $\begin{array}{c}\mathbf{K r} \\
\text { Streamflow }\end{array}$ \\
\hline $2 / 1 / 2017 \quad 23: 45$ & 4.934 & & & 3.051 & 1.883 & & & 923 & 959 & & \\
\hline $2 / 2 / 2017 \quad 0: 45$ & 4.278 & 0,143 & 0,867 & 3.021 & 1.256 & 0,404 & 0,667 & 673 & 584 & 0 & 0,609 \\
\hline $2 / 2 / 2017 \quad 1: 45$ & 3.753 & 0,131 & 0,877 & 2.992 & 761 & 0,502 & 0,606 & 490 & 271 & 1 & 0,464 \\
\hline $2 / 2 / 2017 \quad 2: 45$ & 3.532 & 0,061 & 0,941 & 2.963 & 570 & 0,289 & 0,749 & 357 & 213 & 0 & 0,785 \\
\hline $2 / 2 / 2017 \quad 3: 45$ & 3.333 & 0,058 & 0,944 & 2.934 & 400 & 0,354 & 0,702 & 260 & 140 & 0 & 0,657 \\
\hline $2 / 2 / 2017 \quad 4: 45$ & 3.169 & 0,051 & 0,951 & 2.905 & 264 & 0,415 & 0,660 & 189 & 75 & 1 & 0,534 \\
\hline $2 / 2 / 2017 \quad 5: 45$ & 3.034 & 0,043 & 0,957 & 2.877 & 158 & 0,516 & 0,597 & 138 & 20 & 1 & 0,262 \\
\hline $2 / 2 / 2017 \quad 6: 45$ & 2.949 & 0,028 & 0,972 & 2.849 & 101 & 0,449 & 0,638 & 101 & 0 & & \\
\hline $2 / 2 / 2017 \quad 7: 45$ & 2.894 & 0,019 & 0,981 & 2.821 & 73 & 0,317 & 0,728 & 73 & - & & \\
\hline $2 / 2 / 2017 \quad 9: 45$ & 2.801 & 0,011 & 0,989 & 2.766 & 35 & 0,078 & 0,925 & 35 & - & & \\
\hline $2 / 2 / 2017 \quad 10: 45$ & 2.771 & 0,011 & 0,989 & 2.739 & 32 & 0,093 & 0,911 & 32 & - & & \\
\hline 2/2/2017 11:45 & 2.733 & 0,014 & 0,986 & 2.712 & 21 & 0,417 & 0,659 & 21 & - & & \\
\hline $2 / 2 / 2017 \quad 12: 45$ & 2.708 & 0,009 & 0,991 & 2.686 & 23 & $-0,061$ & 1,063 & 23 & - & & \\
\hline $2 / 2 / 2017 \quad 13: 45$ & 2.688 & 0,007 & 0,993 & 2.659 & 29 & $-0,240$ & 1,271 & 29 & - & & \\
\hline $2 / 2 / 2017 \quad 14: 45$ & 2.655 & 0,012 & 0,988 & 2.633 & 22 & 0,269 & 0,764 & 22 & - & & \\
\hline $2 / 2 / 2017 \quad 15: 45$ & 2.620 & 0,013 & 0,987 & 2.608 & 12 & 0,573 & 0,564 & 12 & - & & \\
\hline $2 / 2 / 2017 \quad 16: 45$ & 2.582 & 0,015 & 0,986 & 2.582 & 0 & & & 0 & - & & \\
\hline $2 / 2 / 2017 \quad 17: 45$ & 2.557 & 0,010 & 0,990 & 2.557 & - & & & - & - & & \\
\hline $2 / 2 / 2017 \quad 18: 45$ & 2.542 & 0,006 & 0,994 & 2.542 & - & & & - & - & & \\
\hline $2 / 2 / 2017 \quad 19: 45$ & 2.522 & 0,008 & 0,992 & 2.522 & - & & & - & - & & \\
\hline
\end{tabular}


Lampiran 2. Perhitungan konstanta resesi Sinking Stream Kedungbuntung

Puncak Banjir 3 Februari 2017 04:30

\begin{tabular}{|c|c|c|c|c|c|c|c|c|c|c|c|}
\hline Date & $\mathbf{Q}(\mathbf{L t})$ & $\begin{array}{c}\text { Alpha } \\
\text { Bas eflow }\end{array}$ & $\begin{array}{c}\mathbf{K r} \\
\text { Baseflow }\end{array}$ & $\begin{array}{c}\text { Q } \\
\text { Baseflow }\end{array}$ & $\begin{array}{c}\mathrm{Q} \\
\text { Interflow + } \\
\text { Streamflow }\end{array}$ & $\begin{array}{c}\text { Alpha } \\
\text { Interflow }\end{array}$ & $\begin{array}{c}\mathbf{K r} \\
\text { Interflow }\end{array}$ & $\begin{array}{c}Q \\
\text { Interflow }\end{array}$ & $\begin{array}{c}\text { Q } \\
\text { Streamflow }\end{array}$ & $\begin{array}{c}\text { Alpha } \\
\text { Streamflow }\end{array}$ & $\begin{array}{c}\mathbf{K r} \\
\text { Streamflow }\end{array}$ \\
\hline $2 / 3 / 2017 \quad 4: 30$ & 5.617 & & & 3.014 & 2.603 & & & 1.484 & 1.119 & & \\
\hline $2 / 3 / 2017 \quad 5: 30$ & 5.060 & 0,104 & 0,901 & 2.988 & 2.072 & 0,228 & 0,796 & 1.048 & 1.024 & 0,088 & 0,916 \\
\hline $2 / 3 / 2017 \quad 6: 30$ & 4.135 & 0,202 & 0,817 & 2.963 & 1.172 & 0,570 & 0,566 & 740 & 432 & 0,863 & 0,422 \\
\hline $2 / 3 / 2017 \quad 7: 30$ & 3.706 & 0,110 & 0,896 & 2.938 & 768 & 0,423 & 0,655 & 522 & 245 & 0,566 & 0,568 \\
\hline $2 / 3 / 2017 \quad 8: 30$ & 3.438 & 0,075 & 0,928 & 2.913 & 525 & 0,380 & 0,684 & 369 & 156 & 0,452 & 0,636 \\
\hline $2 / 3 / 2017 \quad 9: 30$ & 3.249 & 0,057 & 0,945 & 2.888 & 361 & 0,376 & 0,687 & 260 & 100 & 0,444 & 0,641 \\
\hline $2 / 3 / 2017 \quad 10: 30$ & 3.104 & 0,046 & 0,955 & 2.864 & 240 & 0,406 & 0,667 & 184 & 56 & 0,573 & 0,564 \\
\hline $2 / 3 / 2017 \quad 11: 30$ & 2.994 & 0,036 & 0,965 & 2.840 & 155 & 0,441 & 0,643 & 130 & 25 & 0,823 & 0,439 \\
\hline $2 / 3 / 2017 \quad 12: 30$ & 2.919 & 0,025 & 0,975 & 2.816 & 103 & 0,401 & 0,670 & 92 & 12 & 0,735 & 0,479 \\
\hline $2 / 3 / 2017 \quad 13: 30$ & 2.856 & 0,022 & 0,979 & 2.792 & 65 & 0,470 & 0,625 & 65 & 0 & & \\
\hline $2 / 3 / 2017 \quad 14: 30$ & 2.814 & 0,015 & 0,985 & 2.768 & 46 & 0,348 & 0,706 & 46 & - & & \\
\hline $2 / 3 / 2017 \quad 15: 30$ & 2.771 & 0,015 & 0,985 & 2.745 & 26 & 0,547 & 0,578 & 26 & - & & \\
\hline $2 / 3 / 2017 \quad 16: 30$ & 2.731 & 0,015 & 0,985 & 2.721 & 9 & 1,028 & 0,358 & 9 & - & & \\
\hline $2 / 3 / 2017 \quad 17: 30$ & 2.716 & 0,006 & 0,994 & 2.698 & 17 & $-0,611$ & 1,842 & 17 & - & & \\
\hline 2/3/2017 18:30 & 2.676 & 0,015 & 0,985 & 2.676 & 0 & & & 0 & - & & \\
\hline $2 / 3 / 2017 \quad 19: 30$ & 2.653 & 0,009 & 0,992 & 2.653 & - & & & - & - & & \\
\hline $2 / 3 / 2017 \quad 20: 30$ & 2.618 & 0,013 & 0,987 & 2.618 & - & & & - & - & & \\
\hline 2/3/2017 21:30 & 2.613 & 0,002 & 0,998 & 2.613 & - & & & - & - & & \\
\hline $2 / 3 / 2017 \quad 22: 30$ & 2.570 & 0,017 & 0,984 & 2.570 & - & & & - & - & & \\
\hline
\end{tabular}


Lampiran 2. Perhitungan konstanta resesi Sinking Stream Kedungbuntung

Puncak Banjir 15 Februari 2017 00:00

\begin{tabular}{|c|c|c|c|c|c|c|c|c|c|c|c|}
\hline Date & $\mathbf{Q}(\mathbf{L t})$ & $\begin{array}{c}\text { Alpha } \\
\text { Baseflow }\end{array}$ & $\begin{array}{c}\mathbf{K r} \\
\text { Baseflow }\end{array}$ & $\begin{array}{c}Q \\
\text { Baseflow }\end{array}$ & $\begin{array}{c}\text { Q } \\
\text { Interflow + } \\
\text { Streamflow }\end{array}$ & $\begin{array}{c}\text { Alpha } \\
\text { Interflow }\end{array}$ & $\begin{array}{c}\mathbf{K r} \\
\text { Interflow }\end{array}$ & $\begin{array}{c}\text { Q } \\
\text { Interflow }\end{array}$ & $\begin{array}{c}\text { Q } \\
\text { Streamflow }\end{array}$ & $\begin{array}{c}\text { Alpha } \\
\text { Streamflow }\end{array}$ & $\begin{array}{c}\mathbf{K r} \\
\text { Streamflow }\end{array}$ \\
\hline 2/15/2017 0:00 & 3.289 & & & 2.728 & 561 & & & 406 & 154 & & \\
\hline 2/15/2017 1:00 & 3.147 & 0,044 & 0,957 & 2.708 & 439 & 0,245 & 0,783 & 333 & 106 & 0,378 & 0,685 \\
\hline $2 / 15 / 2017 \quad 2: 00$ & 2.987 & 0,052 & 0,949 & 2.688 & 299 & 0,384 & 0,681 & 273 & 26 & 1,404 & 0,246 \\
\hline $2 / 15 / 2017 \quad 3: 00$ & 2.891 & 0,032 & 0,968 & 2.668 & 224 & 0,290 & 0,749 & 224 & - & & \\
\hline $2 / 15 / 2017 \quad 4: 00$ & 2.831 & 0,021 & 0,979 & 2.648 & 183 & 0,199 & 0,820 & 183 & - & & \\
\hline 2/15/2017 5:00 & 2.769 & 0,022 & 0,978 & 2.628 & 140 & 0,268 & 0,765 & 140 & - & & \\
\hline 2/15/2017 6:00 & 2.691 & 0,029 & 0,972 & 2.609 & 82 & 0,538 & 0,584 & 82 & - & & \\
\hline 2/15/2017 7:00 & 2.628 & 0,024 & 0,977 & 2.589 & 38 & 0,757 & 0,469 & 38 & - & & \\
\hline 2/15/2017 8:00 & 2.608 & 0,008 & 0,992 & 2.570 & 38 & 0,024 & 0,976 & 38 & - & & \\
\hline $2 / 15 / 2017 \quad 10: 00$ & 2.560 & 0,003 & 0,997 & 2.532 & 28 & $-0,529$ & 1,698 & 28 & - & & \\
\hline 2/15/2017 11:00 & 2.539 & 0,008 & 0,992 & 2.513 & 26 & 0,051 & 0,951 & 26 & - & & \\
\hline 2/15/2017 $12: 00$ & 2.524 & 0,006 & 0,994 & 2.494 & 30 & $-0,126$ & 1,134 & 30 & - & & \\
\hline 2/15/2017 13:00 & 2.486 & 0,015 & 0,985 & 2.476 & 11 & 1,043 & 0,352 & 11 & & & \\
\hline 2/15/2017 14:00 & 2.461 & 0,010 & 0,990 & 2.458 & 4 & 1,058 & 0,347 & 4 & & & \\
\hline 2/15/2017 15:00 & 2.449 & 0,005 & 0,995 & 2.439 & 9 & $-0,932$ & 2,539 & 9 & & & \\
\hline 2/15/2017 16:00 & 2.438 & 0,004 & 0,996 & 2.421 & 17 & $-0,623$ & 1,864 & 17 & & & \\
\hline 2/15/2017 17:00 & 2.418 & 0,008 & 0,992 & 2.403 & 15 & 0,139 & 0,870 & 15 & & & \\
\hline 2/15/2017 18:00 & 2.385 & 0,014 & 0,986 & 2.385 & 0 & & & 0 & & & \\
\hline 2/15/2017 19:00 & 2.368 & 0,007 & 0,993 & 2.368 & - & & & - & & & \\
\hline 2/15/2017 20:00 & 2.345 & 0,010 & 0,990 & 2.345 & - & & & - & & & \\
\hline 2/15/2017 21:00 & 2.317 & 0,012 & 0,988 & 2.317 & - & & & - & & & \\
\hline
\end{tabular}


Lampiran 2. Perhitungan konstanta resesi Sinking Stream Kedungbuntung

Puncak Banjir 1 Maret 2017 06:15

\begin{tabular}{|c|c|c|c|c|c|c|c|c|c|c|c|}
\hline Date & $Q(\mathbf{L t})$ & $\begin{array}{c}\text { Alpha } \\
\text { Baseflow }\end{array}$ & $\begin{array}{c}\text { Kr } \\
\text { Baseflow }\end{array}$ & $\begin{array}{c}Q \\
\text { Baseflow }\end{array}$ & $\begin{array}{c}\mathbf{Q} \\
\text { Interflow + } \\
\text { Streamflow }\end{array}$ & $\begin{array}{c}\text { Alpha } \\
\text { Interflow }\end{array}$ & $\begin{array}{c}\mathbf{K r} \\
\text { Interflow }\end{array}$ & $\begin{array}{c}Q \\
\text { Interflow }\end{array}$ & $\begin{array}{c}\text { Q } \\
\text { Streamflow }\end{array}$ & $\begin{array}{c}\text { Alpha } \\
\text { Streamflow }\end{array}$ & $\begin{array}{c}\mathbf{K r} \\
\text { Streamflow }\end{array}$ \\
\hline $3 / 1 / 2017 \quad 16: 15$ & 11.215 & & & 4.142 & 7.073 & & & 2.439 & 4.634 & & \\
\hline $3 / 1 / 2017 \quad 17: 15$ & 8.848 & 0,237 & 0,789 & 4.002 & 4.845 & 0,378 & 0,685 & 1.362 & 3.483 & 0,285 & 0,752 \\
\hline $3 / 1 / 2017 \quad 18: 15$ & 6.409 & 0,322 & 0,724 & 3.867 & 2.542 & 0,645 & 0,525 & 761 & 1.781 & 0,671 & 0,511 \\
\hline $3 / 1 / 2017 \quad 19: 15$ & 4.770 & 0,295 & 0,744 & 3.737 & 1.033 & 0,900 & 0,407 & 425 & 609 & 1,074 & 0,342 \\
\hline $3 / 1 / 2017 \quad 20: 15$ & 3.908 & 0,199 & 0,819 & 3.611 & 297 & 1,245 & 0,288 & 237 & 60 & 2,311 & 0,099 \\
\hline $3 / 1 / 2017 \quad 21: 15$ & 3.621 & 0,076 & 0,927 & 3.489 & 132 & 0,809 & 0,445 & 132 & 0 & 13,967 & 0,000 \\
\hline $3 / 1 / 2017 \quad 22: 15$ & 3.445 & 0,050 & 0,951 & 3.371 & 74 & 0,583 & 0,558 & 74 & & & \\
\hline $3 / 1 / 2017 \quad 23: 15$ & 3.301 & 0,043 & 0,958 & 3.258 & 43 & 0,533 & 0,587 & 43 & & & \\
\hline $3 / 2 / 2017 \quad 0: 15$ & 3.161 & 0,043 & 0,958 & 3.148 & 14 & 1,152 & 0,316 & 14 & & & \\
\hline $3 / 2 / 2017 \quad 1: 15$ & 3.042 & 0,039 & 0,962 & 3.042 & 0 & & & 0 & & & \\
\hline $3 / 2 / 2017 \quad 2: 15$ & 2.939 & 0,034 & 0,966 & 2.939 & - & & & - & & & \\
\hline $3 / 2 / 2017 \quad 3: 15$ & 2.841 & 0,034 & 0,967 & 2.841 & - & & & - & & & \\
\hline $3 / 2 / 2017 \quad 4: 15$ & 2.819 & 0,008 & 0,992 & 2.819 & - & & & - & & & \\
\hline $3 / 2 / 2017 \quad 5: 15$ & 2.774 & 0,016 & 0,984 & 2.774 & - & & & - & & & \\
\hline $3 / 2 / 2017 \quad 6: 15$ & 2.721 & 0,019 & 0,981 & 2.721 & - & & & - & & & \\
\hline $3 / 2 / 2017 \quad 7: 15$ & 2.663 & 0,021 & 0,979 & 2.663 & - & & & - & & & \\
\hline $3 / 2 / 20178: 15$ & 2.618 & 0,017 & 0,983 & 2.618 & - & & & - & & & \\
\hline
\end{tabular}


Lampiran 2. Perhitungan konstanta resesi Sinking Stream Kedungbuntung

Puncak Banjir 5 Maret 2017 15:30

\begin{tabular}{|c|c|c|c|c|c|c|c|c|c|c|c|}
\hline Date & $\mathbf{Q}(\mathbf{L t})$ & $\begin{array}{c}\text { Alpha } \\
\text { Baseflow }\end{array}$ & $\begin{array}{c}\mathbf{K r} \\
\text { Baseflow }\end{array}$ & $\begin{array}{c}\text { Q } \\
\text { Baseflow }\end{array}$ & $\begin{array}{c}\mathbf{Q} \\
\text { Interflow + } \\
\text { Streamflow }\end{array}$ & $\begin{array}{c}\text { Alpha } \\
\text { Interflow }\end{array}$ & $\begin{array}{c}\mathbf{K r} \\
\text { Interflow }\end{array}$ & $\begin{array}{c}\text { Q } \\
\text { Interflow }\end{array}$ & $\begin{array}{c}\text { Q } \\
\text { Streamflow }\end{array}$ & $\begin{array}{c}\text { Alpha } \\
\text { Streamflow }\end{array}$ & $\begin{array}{c}\mathbf{K r} \\
\text { Streamflow }\end{array}$ \\
\hline $3 / 5 / 2017 \quad 15: 30$ & 6.644 & & & 3.202 & 3.443 & & & 1.715 & 1.728 & & \\
\hline 3/5/2017 16:30 & 5.641 & 0,164 & 0,849 & 3.145 & 2.496 & 0,321 & 0,725 & 1.122 & 1.374 & 0,229 & 0,795 \\
\hline $3 / 5 / 2017 \quad 17: 30$ & 4.157 & 0,305 & 0,737 & 3.088 & 1.069 & 0,848 & 0,428 & 735 & 334 & 1,414 & 0,243 \\
\hline $3 / 5 / 2017 \quad 18: 30$ & 3.612 & 0,141 & 0,869 & 3.033 & 578 & 0,614 & 0,541 & 481 & 98 & 1,231 & 0,292 \\
\hline $3 / 5 / 2017 \quad 19: 30$ & 3.294 & 0,092 & 0,912 & 2.979 & 315 & 0,608 & 0,544 & 315 & 0 & & \\
\hline 3/5/2017 20:30 & 3.132 & 0,050 & 0,951 & 2.926 & 206 & 0,424 & 0,655 & 206 & - & & \\
\hline $3 / 5 / 2017 \quad 21: 30$ & 2.974 & 0,052 & 0,950 & 2.873 & 101 & 0,714 & 0,490 & 101 & - & & \\
\hline $3 / 5 / 2017 \quad 22: 30$ & 2.851 & 0,042 & 0,959 & 2.822 & 30 & 1,227 & 0,293 & 30 & - & & \\
\hline $3 / 5 / 2017 \quad 23: 30$ & 2.849 & 0,001 & 0,999 & 2.771 & 78 & $-0,964$ & 2,623 & 78 & - & & \\
\hline $3 / 6 / 2017 \quad 0: 30$ & 2.758 & 0,032 & 0,968 & 2.722 & 37 & 0,746 & 0,474 & 37 & - & & \\
\hline $3 / 6 / 2017 \quad 1: 30$ & 2.673 & 0,031 & 0,969 & 2.673 & 0 & & & 0 & - & & \\
\hline $3 / 6 / 2017 \quad 2: 30$ & 2.625 & 0,018 & 0,982 & 2.625 & - & & & - & - & & \\
\hline $3 / 6 / 2017 \quad 3: 30$ & 2.575 & 0,019 & 0,981 & 2.575 & - & & & - & - & & \\
\hline $3 / 6 / 2017 \quad 4: 30$ & 2.542 & 0,013 & 0,987 & 2.542 & - & & & - & - & & \\
\hline $3 / 6 / 2017 \quad 5: 30$ & 2.499 & 0,017 & 0,983 & 2.499 & - & & & - & - & & \\
\hline $3 / 6 / 2017 \quad 6: 30$ & 2.476 & 0,009 & 0,991 & 2.476 & - & & & - & - & & \\
\hline $3 / 6 / 2017 \quad 7: 30$ & 2.474 & 0,001 & 0,999 & 2.474 & - & & & - & - & & \\
\hline
\end{tabular}


Lampiran 2. Perhitungan konstanta resesi Sinking Stream Kedungbuntung

Puncak Banjir 16 Maret 2017 19:00

\begin{tabular}{|c|c|c|c|c|c|c|c|c|c|c|c|}
\hline Date & $Q(\mathbf{L t})$ & $\begin{array}{c}\text { Alpha } \\
\text { Baseflow }\end{array}$ & $\begin{array}{c}\text { Kr } \\
\text { Baseflow }\end{array}$ & $\begin{array}{c}Q \\
\text { Baseflow }\end{array}$ & $\begin{array}{c}Q \\
\text { Interflow + } \\
\text { Streamflow }\end{array}$ & $\begin{array}{c}\text { Alpha } \\
\text { Interflow }\end{array}$ & $\begin{array}{c}\mathrm{Kr} \\
\text { Interflow }\end{array}$ & $\begin{array}{c}\mathbf{Q} \\
\text { Interflow }\end{array}$ & $\begin{array}{c}\text { Q } \\
\text { Streamflow }\end{array}$ & $\begin{array}{c}\text { Alpha } \\
\text { Streamflow }\end{array}$ & $\begin{array}{c}\text { Kr } \\
\text { Streamflow }\end{array}$ \\
\hline 3/16/2017 19:00 & 4.899 & & & 2.872 & 2.028 & & & 311 & 1.716 & & \\
\hline $3 / 16 / 2017 \quad 20: 00$ & 4.332 & 0,123 & 0,884 & 2.844 & 1.488 & 0,309 & 0,734 & 255 & 1.233 & 0,331 & 0,718 \\
\hline 3/16/2017 21:00 & 3.554 & 0,198 & 0,821 & 2.816 & 739 & 0,700 & 0,496 & 210 & 529 & 0,846 & 0,429 \\
\hline $3 / 16 / 2017 \quad 22: 00$ & 3.281 & 0,080 & 0,923 & 2.788 & 493 & 0,405 & 0,667 & 172 & 321 & 0,500 & 0,607 \\
\hline 3/16/2017 23:00 & 3.087 & 0,061 & 0,941 & 2.761 & 326 & 0,414 & 0,661 & 141 & 185 & 0,553 & 0,575 \\
\hline 3/17/2017 0:00 & 2.947 & 0,046 & 0,955 & 2.734 & 213 & 0,426 & 0,653 & 116 & 97 & 0,644 & 0,525 \\
\hline $3 / 17 / 2017 \quad 1: 00$ & 2.831 & 0,040 & 0,961 & 2.707 & 124 & 0,538 & 0,584 & 95 & 29 & 1,198 & 0,302 \\
\hline $3 / 17 / 2017 \quad 2: 00$ & 2.758 & 0,026 & 0,974 & 2.681 & 78 & 0,467 & 0,627 & 78 & 0 & & \\
\hline $3 / 17 / 2017 \quad 3: 00$ & 2.718 & 0,015 & 0,985 & 2.654 & 64 & 0,198 & 0,820 & 64 & - & & \\
\hline $3 / 17 / 2017 \quad 4: 00$ & 2.663 & 0,021 & 0,980 & 2.628 & 34 & 0,616 & 0,540 & 34 & - & & \\
\hline 3/17/2017 5:00 & 2.610 & 0,020 & 0,980 & 2.603 & 7 & & & 7 & - & & \\
\hline $3 / 17 / 2017 \quad 6: 00$ & 2.577 & 0,013 & 0,987 & 2.577 & 0 & & & 0 & - & & \\
\hline $3 / 17 / 2017 \quad 7: 00$ & 2.552 & 0,010 & 0,990 & 2.552 & - & & & - & - & & \\
\hline $3 / 17 / 2017 \quad 8: 00$ & 2.519 & 0,013 & 0,987 & 2.519 & - & & & - & - & & \\
\hline 3/17/2017 9:00 & 2.474 & 0,018 & 0,982 & 2.474 & - & & & - & - & & \\
\hline 3/17/2017 10:00 & 2.459 & 0,006 & 0,994 & 2.459 & - & & & - & - & & \\
\hline 3/17/2017 11:00 & 2.448 & 0,004 & 0,996 & 2.448 & - & & & - & - & & \\
\hline
\end{tabular}


Lampiran 2. Perhitungan konstanta resesi Sinking Stream Kedungbuntung

Puncak Banjir 26 Maret 2017 04:45

\begin{tabular}{|c|c|c|c|c|c|c|c|c|c|c|c|}
\hline Date & $Q(\mathbf{L t})$ & $\begin{array}{c}\text { Alpha } \\
\text { Baseflow }\end{array}$ & $\begin{array}{c}\text { Kr } \\
\text { Baseflow }\end{array}$ & $\begin{array}{c}Q \\
\text { Baseflow }\end{array}$ & $\begin{array}{c}\mathrm{Q} \\
\text { Interflow + } \\
\text { Streamflow }\end{array}$ & $\begin{array}{c}\text { Alpha } \\
\text { Interflow }\end{array}$ & $\begin{array}{c}\mathrm{Kr} \\
\text { Interflow }\end{array}$ & $\begin{array}{c}\text { Q } \\
\text { Interflow }\end{array}$ & $\begin{array}{c}\text { Q } \\
\text { Streamflow }\end{array}$ & $\begin{array}{c}\text { Alpha } \\
\text { Streamflow }\end{array}$ & $\begin{array}{c}\mathbf{K r} \\
\text { Streamflow }\end{array}$ \\
\hline $3 / 26 / 2017 \quad 4: 45$ & 3.532 & & & 2.483 & 1.049 & & & 956 & 93 & & \\
\hline $3 / 26 / 2017 \quad 5: 45$ & 3.351 & 0,053 & 0,949 & 2.478 & 873 & 0,184 & 0,832 & 789 & 85 & 0,093 & 0,911 \\
\hline $3 / 26 / 2017 \quad 6: 45$ & 3.159 & 0,059 & 0,943 & 2.472 & 687 & 0,240 & 0,786 & 650 & 36 & 0,843 & 0,431 \\
\hline $3 / 26 / 2017 \quad 7: 45$ & 3.047 & 0,036 & 0,964 & 2.467 & 580 & 0,170 & 0,844 & 536 & 43 & $-0,174$ & 1,190 \\
\hline $3 / 26 / 2017 \quad 8: 45$ & 2.904 & 0,048 & 0,953 & 2.462 & 442 & 0,271 & 0,763 & 442 & 0 & 13,536 & 0,000 \\
\hline $3 / 26 / 2017 \quad 9: 45$ & 2.821 & 0,029 & 0,972 & 2.457 & 364 & 0,193 & 0,825 & 364 & - & & \\
\hline 3/26/2017 10:45 & 2.789 & 0,012 & 0,988 & 2.452 & 337 & 0,078 & 0,925 & 337 & - & & \\
\hline $3 / 26 / 2017 \quad 11: 45$ & 2.748 & 0,015 & 0,986 & 2.446 & 302 & 0,110 & 0,896 & 302 & - & & \\
\hline $3 / 26 / 2017 \quad 12: 45$ & 2.698 & 0,018 & 0,982 & 2.441 & 257 & 0,162 & 0,851 & 257 & - & & \\
\hline $3 / 26 / 2017 \quad 13: 45$ & 2.628 & 0,026 & 0,974 & 2.436 & 192 & 0,294 & 0,746 & 192 & - & & \\
\hline $3 / 26 / 2017 \quad 14: 45$ & 2.572 & 0,021 & 0,979 & 2.431 & 141 & 0,305 & 0,737 & 141 & - & & \\
\hline $3 / 26 / 2017 \quad 15: 45$ & 2.547 & 0,010 & 0,990 & 2.426 & 121 & 0,154 & 0,858 & 121 & - & & \\
\hline $3 / 26 / 2017 \quad 16: 45$ & 2.504 & 0,017 & 0,983 & 2.421 & 83 & 0,374 & 0,688 & 83 & - & & \\
\hline $3 / 26 / 2017 \quad 17: 45$ & 2.446 & 0,023 & 0,977 & 2.416 & 30 & 1,011 & 0,364 & 30 & - & & \\
\hline $3 / 26 / 2017 \quad 18: 45$ & 2.421 & 0,010 & 0,990 & 2.411 & 10 & 1,098 & 0,333 & 10 & - & & \\
\hline $3 / 26 / 2017 \quad 19: 45$ & 2.406 & 0,006 & 0,994 & 2.406 & 0 & & & 0 & - & & \\
\hline $3 / 26 / 2017 \quad 20: 45$ & 2.401 & 0,002 & 0,998 & 2.401 & - & & & - & - & & \\
\hline $3 / 26 / 2017 \quad 21: 45$ & 2.401 & 0,000 & 1,000 & 2.401 & - & & & - & - & & \\
\hline
\end{tabular}




\section{Lampiran 2. Perhitungan konstanta resesi Sinking Stream Kedungbuntung}

Puncak Banjir 31 Maret 2017 17:00

\begin{tabular}{|c|c|c|c|c|c|c|c|c|c|c|c|}
\hline Date & $\mathbf{Q}(\mathbf{L t})$ & $\begin{array}{c}\text { Alpha } \\
\text { Baseflow }\end{array}$ & $\begin{array}{c}\mathrm{Kr} \\
\text { Baseflow }\end{array}$ & $\begin{array}{c}Q \\
\text { Baseflow }\end{array}$ & $\begin{array}{c}\mathrm{Q} \\
\text { Interflow + } \\
\text { Streamflow }\end{array}$ & $\begin{array}{c}\text { Alpha } \\
\text { Interflow }\end{array}$ & $\begin{array}{c}\mathbf{K r} \\
\text { Interflow }\end{array}$ & $\begin{array}{c}\text { Q } \\
\text { Interflow }\end{array}$ & $\begin{array}{c}\text { Q } \\
\text { Streamflow }\end{array}$ & $\begin{array}{c}\text { Alpha } \\
\text { Streamflow }\end{array}$ & $\begin{array}{c}\mathbf{K r} \\
\text { Streamflow }\end{array}$ \\
\hline $3 / 31 / 2017 \quad 17: 00$ & 5.796 & & & 2.982 & 2.814 & & & 735 & 2.079 & & \\
\hline 3/31/2017 18:00 & 4.809 & 0,187 & 0,830 & 2.950 & 1.860 & 0,414 & 0,661 & 654 & 1.206 & 0,545 & 0,580 \\
\hline 3/31/2017 19:00 & 3.829 & 0,228 & 0,796 & 2.917 & 912 & 0,712 & 0,490 & 582 & 331 & 1,294 & 0,274 \\
\hline $3 / 31 / 2017 \quad 20: 00$ & 3.428 & 0,111 & 0,895 & 2.885 & 543 & 0,519 & 0,595 & 517 & 26 & 2,561 & 0,077 \\
\hline 3/31/2017 21:00 & 3.314 & 0,034 & 0,967 & 2.853 & 460 & 0,165 & 0,848 & 460 & 0 & & \\
\hline $3 / 31 / 2017 \quad 22: 00$ & 3.231 & 0,025 & 0,975 & 2.822 & 409 & 0,117 & 0,890 & 409 & - & & \\
\hline 3/31/2017 23:00 & 3.142 & 0,028 & 0,972 & 2.791 & 351 & 0,155 & 0,856 & 351 & - & & \\
\hline 4/1/2017 0:00 & 3.024 & 0,038 & 0,963 & 2.760 & 264 & 0,284 & 0,753 & 264 & - & & \\
\hline $4 / 1 / 2017 \quad 1: 00$ & 2.942 & 0,028 & 0,973 & 2.730 & 212 & 0,221 & 0,802 & 212 & - & & \\
\hline $4 / 1 / 2017 \quad 2: 00$ & 2.851 & 0,031 & 0,969 & 2.700 & 151 & 0,335 & 0,715 & 151 & - & & \\
\hline 4/1/2017 3:00 & 2.748 & 0,037 & 0,964 & 2.670 & 78 & 0,662 & 0,516 & 78 & - & & \\
\hline 4/1/2017 4:00 & 2.703 & 0,017 & 0,984 & 2.641 & 62 & 0,228 & 0,796 & 62 & - & & \\
\hline 4/1/2017 5:00 & 2.643 & 0,023 & 0,978 & 2.612 & 31 & 0,703 & 0,495 & 31 & - & & \\
\hline 4/1/2017 6:00 & 2.605 & 0,014 & 0,986 & 2.583 & 22 & 0,349 & 0,705 & 22 & - & & \\
\hline 4/1/2017 7:00 & 2.560 & 0,018 & 0,983 & 2.555 & 5 & & & 5 & - & & \\
\hline 4/1/2017 8:00 & 2.527 & 0,013 & 0,987 & 2.527 & 0 & & & 0 & - & & \\
\hline 4/1/2017 9:00 & 2.499 & 0,011 & 0,989 & 2.499 & - & & & - & - & & \\
\hline 4/1/2017 10:00 & 2.461 & 0,015 & 0,985 & 2.461 & - & & & - & - & & \\
\hline
\end{tabular}


Lampiran 2. Perhitungan konstanta resesi Sinking Stream Kedungbuntung

Puncak Banjir 26 April 2017 21:00

\begin{tabular}{|c|c|c|c|c|c|c|c|c|c|c|c|}
\hline Date & $\mathbf{Q}(\mathbf{L t})$ & $\begin{array}{c}\text { Alpha } \\
\text { Baseflow }\end{array}$ & $\begin{array}{c}\mathbf{K r} \\
\text { Baseflow }\end{array}$ & $\begin{array}{c}\text { Q } \\
\text { Baseflow }\end{array}$ & $\begin{array}{c}\mathbf{Q} \\
\text { Interflow + } \\
\text { Streamflow }\end{array}$ & $\begin{array}{c}\text { Alpha } \\
\text { Interflow }\end{array}$ & $\begin{array}{c}\mathbf{K r} \\
\text { Interflow }\end{array}$ & $\begin{array}{c}Q \\
\text { Interflow }\end{array}$ & $\begin{array}{c}Q \\
\text { Streamflow }\end{array}$ & $\begin{array}{c}\text { Alpha } \\
\text { Streamflow }\end{array}$ & $\begin{array}{c}\mathbf{K r} \\
\text { Streamflow }\end{array}$ \\
\hline 4/26/2017 21:00 & 5.614 & & & 2.873 & 2.741 & & & 1.806 & 935 & & \\
\hline 4/26/2017 22:00 & 4.775 & 0,162 & 0,850 & 2.854 & 1.921 & 0,356 & 0,701 & 1.217 & 703 & 0,285 & 0,752 \\
\hline 4/26/2017 23:00 & 3.733 & 0,246 & 0,782 & 2.836 & 897 & 0,761 & 0,467 & 820 & 77 & 2,216 & 0,109 \\
\hline 4/27/2017 $0: 00$ & 3.406 & 0,092 & 0,912 & 2.817 & 588 & 0,422 & 0,656 & 553 & 35 & 0,774 & 0,461 \\
\hline 4/27/2017 $1: 00$ & 3.174 & 0,070 & 0,932 & 2.799 & 375 & 0,450 & 0,638 & 373 & 3 & 2,640 & 0,071 \\
\hline $4 / 27 / 2017 \quad 2: 00$ & 3.032 & 0,046 & 0,955 & 2.780 & 251 & 0,401 & 0,669 & 251 & 0 & & \\
\hline 4/27/2017 3:00 & 2.932 & 0,034 & 0,967 & 2.762 & 169 & 0,394 & 0,674 & 169 & - & & \\
\hline 4/27/2017 4:00 & 2.834 & 0,034 & 0,967 & 2.744 & 90 & 0,636 & 0,529 & 90 & - & & \\
\hline 4/27/2017 5:00 & 2.781 & 0,019 & 0,981 & 2.726 & 55 & 0,490 & 0,612 & 55 & - & & \\
\hline 4/27/2017 6:00 & 2.733 & 0,017 & 0,983 & 2.708 & 25 & 0,786 & 0,456 & 25 & - & & \\
\hline 4/27/2017 7:00 & 2.691 & 0,016 & 0,984 & 2.691 & 0 & & & 0 & - & & \\
\hline 4/27/2017 8:00 & 2.673 & 0,007 & 0,993 & 2.673 & - & & & - & - & & \\
\hline 4/27/2017 9:00 & 2.638 & 0,013 & 0,987 & 2.638 & - & & & - & - & & \\
\hline 4/27/2017 10:00 & 2.597 & 0,015 & 0,985 & 2.597 & - & & & - & - & & \\
\hline 4/27/2017 11:00 & 2.595 & 0,001 & 0,999 & 2.595 & - & & & - & - & & \\
\hline 4/27/2017 12:00 & 2.572 & 0,009 & 0,991 & 2.572 & - & & & - & - & & \\
\hline 4/27/2017 13:00 & 2.545 & 0,011 & 0,989 & 2.545 & - & & & - & - & & \\
\hline
\end{tabular}


Lampiran 3. Perhitungan hujan efektif Gua Pindul

Waktu awal hujan 5 Januari 2017 15:30

\begin{tabular}{|c|c|c|c|c|c|c|c|c|c|c|c|}
\hline Waktu & $\begin{array}{c}\mathrm{Q} \\
(\mathrm{m} 3 / \mathrm{s})\end{array}$ & $\mathbf{P}$ & $\begin{array}{c}\text { Bas eflow } \\
(\mathrm{m} 3 / \mathrm{s})\end{array}$ & $\begin{array}{c}\text { DRO } \\
(\mathrm{m} 3 / \mathrm{s})\end{array}$ & $\begin{array}{c}\text { Total } \\
\text { DRO } \\
(\mathrm{m} 3 / \mathbf{s}) \\
\end{array}$ & $\begin{array}{c}\text { Volume } \\
\text { DRO } \\
\text { (m3) }\end{array}$ & $\begin{array}{l}\text { Luas } \\
\text { DTA } \\
(\mathbf{m} 2)\end{array}$ & $\begin{array}{l}\text { Tebal } \\
\text { DRO } \\
(\mathrm{mm})\end{array}$ & $\begin{array}{c}\phi(\mathrm{mm} / \\
15 \\
\text { menit })\end{array}$ & $\begin{array}{c}\begin{array}{c}\text { Hujan } \\
\text { efektif } \\
(\mathbf{m m})\end{array} \\
\end{array}$ & $\begin{array}{c}\text { Total } \\
\text { Hujan } \\
\text { Efetif } \\
\end{array}$ \\
\hline $5 / 1 / 2017 \quad 14: 45$ & 3,71 & 0 & 3,71 & 0,000 & 103 & 92664 & 15440000 & 6,00 & 5,93 & & 6,00 \\
\hline $5 / 1 / 2017 \quad 15: 00$ & 3,71 & 0 & 3,71 & 0,000 & & & & & & & \\
\hline 5/1/2017 15:15 & 3,72 & 0 & 3,72 & 0,000 & & & & & & & \\
\hline 5/1/2017 15:30 & 3,71 & 2,8 & 3,71 & 0,000 & & & & & & & \\
\hline 5/1/2017 15:45 & 3,77 & 10,2 & 3,71 & 0,062 & & & & & & 4,27 & \\
\hline 5/1/2017 16:00 & 3,88 & 6,6 & 3,72 & 0,158 & & & & & & 0,67 & \\
\hline $5 / 1 / 2017 \quad 16: 15$ & 4,03 & 7 & 3,73 & 0,309 & & & & & & 1,07 & \\
\hline $5 / 1 / 2017 \quad 16: 30$ & 4,40 & 3,6 & 3,73 & 0,673 & & & & & & & \\
\hline $5 / 1 / 2017 \quad 16: 45$ & 5,12 & 1 & 3,74 & 1,378 & & & & & & & \\
\hline 5/1/2017 17:00 & 6,10 & 0,2 & 3,74 & 2,354 & & & & & & & \\
\hline $5 / 1 / 2017 \quad 17: 15$ & 7,69 & 0,6 & 3,75 & 3,943 & & & & & & & \\
\hline $5 / 1 / 2017 \quad 17: 30$ & 8,19 & 0,4 & 3,76 & 4,436 & & & & & & & \\
\hline $5 / 1 / 2017 \quad 17: 45$ & 8,21 & 0,2 & 3,76 & 4,449 & & & & & & & \\
\hline 5/1/2017 18:00 & 9,97 & 0 & 3,77 & 6,205 & & & & & & & \\
\hline 5/1/2017 18:15 & 10,32 & 0 & 3,77 & 6,546 & & & & & & & \\
\hline $5 / 1 / 2017 \quad 18: 30$ & 10,00 & 0 & 3,78 & 6,215 & & & & & & & \\
\hline $5 / 1 / 2017 \quad 18: 45$ & 9,45 & 0 & 3,79 & 5,664 & & & & & & & \\
\hline $5 / 1 / 2017 \quad 19: 00$ & 8,89 & 0,2 & 3,79 & 5,102 & & & & & & & \\
\hline $5 / 1 / 2017 \quad 19: 15$ & 8,47 & 0 & 3,80 & 4,671 & & & & & & & \\
\hline 5/1/2017 19:30 & 8,06 & 0 & 3,80 & 4,257 & & & & & & & \\
\hline $5 / 1 / 2017 \quad 19: 45$ & 7,62 & 0 & 3,81 & 3,814 & & & & & & & \\
\hline 5/1/2017 20:00 & 7,25 & 0 & 3,82 & 3,431 & & & & & & & \\
\hline $5 / 1 / 2017 \quad 20: 15$ & 6,93 & 0 & 3,82 & 3,109 & & & & & & & \\
\hline $5 / 1 / 2017 \quad 20: 30$ & 6,64 & 0 & 3,83 & 2,814 & & & & & & & \\
\hline
\end{tabular}




\begin{tabular}{|c|c|c|c|c|c|c|c|c|c|c|c|}
\hline Waktu & $\begin{array}{c}\mathbf{Q} \\
(\mathrm{m} 3 / \mathbf{s})\end{array}$ & $\mathbf{P}$ & $\begin{array}{c}\text { Baseflow } \\
(\mathrm{m} 3 / \mathbf{s})\end{array}$ & $\begin{array}{c}\text { DRO } \\
(\mathrm{m} 3 / \mathrm{s})\end{array}$ & 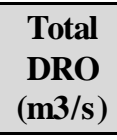 & $\begin{array}{c}\text { Volume } \\
\text { DRO } \\
(\mathrm{m} 3) \\
\end{array}$ & $\begin{array}{l}\text { Luas } \\
\text { DTA } \\
\text { (m2) } \\
\end{array}$ & $\begin{array}{l}\text { Tebal } \\
\text { DRO } \\
\text { (mm) }\end{array}$ & $\begin{array}{c}\phi(\mathbf{m m} / \\
15 \\
\text { menit })\end{array}$ & $\begin{array}{c}\text { Hujan } \\
\text { efektif } \\
(\mathbf{m m})\end{array}$ & $\begin{array}{l}\text { Total } \\
\text { Hujan } \\
\text { Efetif } \\
\end{array}$ \\
\hline $5 / 1 / 2017 \quad 20: 45$ & 6,44 & 0 & 3,83 & 2,609 & & & & & & & \\
\hline 5/1/2017 21:00 & 6,20 & 0 & 3,84 & 2,362 & & & & & & & \\
\hline 5/1/2017 21:15 & 5,97 & 0 & 3,85 & 2,126 & & & & & & & \\
\hline 5/1/2017 21:30 & 5,78 & 0 & 3,85 & 1,922 & & & & & & & \\
\hline 5/1/2017 21:45 & 5,65 & 0 & 3,86 & 1,787 & & & & & & & \\
\hline 5/1/2017 $22: 00$ & 5,50 & 0 & 3,87 & 1,640 & & & & & & & \\
\hline 5/1/2017 22:15 & 5,38 & 0 & 3,87 & 1,505 & & & & & & & \\
\hline 5/1/2017 $22: 30$ & 5,28 & 0 & 3,88 & 1,404 & & & & & & & \\
\hline 5/1/2017 22:45 & 5,19 & 0 & 3,88 & 1,305 & & & & & & & \\
\hline 5/1/2017 23:00 & 5,10 & 0 & 3,89 & 1,212 & & & & & & & \\
\hline 5/1/2017 $23: 15$ & 5,02 & 0 & 3,90 & 1,129 & & & & & & & \\
\hline 5/1/2017 23:30 & 4,95 & 0 & 3,90 & 1,047 & & & & & & & \\
\hline 5/1/2017 23:45 & 4,89 & 0 & 3,91 & 0,983 & & & & & & & \\
\hline 6/1/2017 0:00 & 4,84 & 0 & 3,91 & 0,925 & & & & & & & \\
\hline $6 / 1 / 2017 \quad 0: 15$ & 4,79 & 0 & 3,92 & 0,875 & & & & & & & \\
\hline $6 / 1 / 2017 \quad 0: 30$ & 4,73 & 0 & 3,93 & 0,808 & & & & & & & \\
\hline $6 / 1 / 2017 \quad 0: 45$ & 4,70 & 0 & 3,93 & 0,768 & & & & & & & \\
\hline $6 / 1 / 2017 \quad 1: 00$ & 4,65 & 0 & 3,94 & 0,711 & & & & & & & \\
\hline $6 / 1 / 2017 \quad 1: 15$ & 4,62 & 0 & 3,94 & 0,675 & & & & & & & \\
\hline $6 / 1 / 2017 \quad 1: 30$ & 4,58 & 0 & 3,95 & 0,627 & & & & & & & \\
\hline $6 / 1 / 2017 \quad 1: 45$ & 4,54 & 0 & 3,96 & 0,583 & & & & & & & \\
\hline $6 / 1 / 2017 \quad 2: 00$ & 4,52 & 0 & 3,96 & 0,561 & & & & & & & \\
\hline $6 / 1 / 2017 \quad 2: 15$ & 4,48 & 0 & 3,97 & 0,509 & & & & & & & \\
\hline $6 / 1 / 2017 \quad 2: 30$ & 4,47 & 0 & 3,97 & 0,491 & & & & & & & \\
\hline $6 / 1 / 2017 \quad 2: 45$ & 4,44 & 0 & 3,98 & 0,456 & & & & & & & \\
\hline $6 / 1 / 2017 \quad 3: 00$ & 4,40 & 0 & 3,99 & 0,417 & & & & & & & \\
\hline
\end{tabular}




\begin{tabular}{|c|c|c|c|c|c|c|c|c|c|c|c|}
\hline Waktu & $\underset{(\mathbf{m} 3 / \mathbf{s})}{\mathbf{Q}}$ & $\mathbf{P}$ & $\begin{array}{c}\text { Baseflow } \\
(\mathrm{m} 3 / \mathbf{s})\end{array}$ & $\begin{array}{c}\text { DRO } \\
(\mathbf{m} 3 / \mathbf{s})\end{array}$ & $\begin{array}{c}\text { Total } \\
\text { DRO } \\
(\mathrm{m} 3 / \mathbf{s})\end{array}$ & $\begin{array}{c}\text { Volume } \\
\text { DRO } \\
\text { (m3) }\end{array}$ & $\begin{array}{l}\text { Luas } \\
\text { DTA } \\
\text { (m2) } \\
\end{array}$ & $\begin{array}{l}\text { Tebal } \\
\text { DRO } \\
\text { (mm) }\end{array}$ & $\begin{array}{c}\phi(\mathbf{m m} / \\
15 \\
\text { menit })\end{array}$ & $\begin{array}{l}\text { Hujan } \\
\text { efektif } \\
(\mathbf{m m})\end{array}$ & $\begin{array}{l}\text { Total } \\
\text { Hujan } \\
\text { Ffetif }\end{array}$ \\
\hline 6/1/2017 3:15 & 4,39 & 0 & 3,99 & 0,395 & & & & & & & \\
\hline 6/1/2017 3:30 & 4,37 & 0 & 4,00 & 0,369 & & & & & & & \\
\hline 6/1/2017 3:45 & 4,35 & 0 & 4,01 & 0,342 & & & & & & & \\
\hline 6/1/2017 4:00 & 4,34 & 0 & 4,01 & 0,324 & & & & & & & \\
\hline 6/1/2017 4:15 & 4,32 & 0 & 4,02 & 0,298 & & & & & & & \\
\hline 6/1/2017 4:30 & 4,30 & 0 & 4,02 & 0,272 & & & & & & & \\
\hline 6/1/2017 4:45 & 4,29 & 0 & 4,03 & 0,258 & & & & & & & \\
\hline 6/1/2017 5:00 & 4,27 & 0 & 4,04 & 0,236 & & & & & & & \\
\hline 6/1/2017 5:15 & 4,28 & 0 & 4,04 & 0,234 & & & & & & & \\
\hline 6/1/2017 5:30 & 4,26 & 0 & 4,05 & 0,216 & & & & & & & \\
\hline 6/1/2017 5:45 & 4,24 & 0 & 4,05 & 0,190 & & & & & & & \\
\hline 6/1/2017 6:00 & 4,22 & 0 & 4,06 & 0,164 & & & & & & & \\
\hline 6/1/2017 6:15 & 4,21 & 0 & 4,07 & 0,142 & & & & & & & \\
\hline 6/1/2017 6:30 & 4,19 & 0 & 4,07 & 0,120 & & & & & & & \\
\hline 6/1/2017 6:45 & 4,18 & 0 & 4,08 & 0,106 & & & & & & & \\
\hline 6/1/2017 7:00 & 4,18 & 0 & 4,08 & 0,093 & & & & & & & \\
\hline 6/1/2017 7:15 & 4,15 & 0 & 4,09 & 0,063 & & & & & & & \\
\hline 6/1/2017 7:30 & 4,15 & 0 & 4,10 & 0,049 & & & & & & & \\
\hline 6/1/2017 7:45 & 4,14 & 0 & 4,10 & 0,039 & & & & & & & \\
\hline 6/1/2017 8:00 & 4,13 & 0 & 4,11 & 0,022 & & & & & & & \\
\hline
\end{tabular}




\section{Lampiran 3. Perhitungan Hujan Efektif Gua Pindul}

Waktu awal hujan 8 Januari 2017 15:15

\begin{tabular}{|c|c|c|c|c|c|c|c|c|c|c|c|}
\hline Waktu & $Q(\mathrm{~m} 3 / \mathrm{s})$ & $\mathbf{P}$ & $\begin{array}{c}\text { Baseflow } \\
(\mathrm{m} 3 / \mathrm{s})\end{array}$ & $\begin{array}{l}\text { DRO } \\
(\mathbf{m} 3 / \mathbf{s})\end{array}$ & $\begin{array}{l}\text { Total } \\
\text { DRO } \\
(\mathrm{m} 3 / \mathbf{s})\end{array}$ & $\begin{array}{c}\text { Volume DRO } \\
(\mathrm{m} 3)\end{array}$ & $\begin{array}{l}\text { Luas } \\
\text { DTA } \\
(\mathrm{m} 2)\end{array}$ & $\begin{array}{l}\text { Tebal } \\
\text { DRO } \\
(\mathrm{mm})\end{array}$ & $\begin{array}{c}\phi(\mathrm{mm} / \\
15 \\
\text { menit })\end{array}$ & $\begin{array}{c}\text { Hujan } \\
\text { efektif } \\
(\mathrm{mm})\end{array}$ & $\begin{array}{c}\text { Total } \\
\text { Hujan } \\
\text { Efetif }\end{array}$ \\
\hline $8 / 1 / 2017 \quad 14: 30$ & 3,703 & 0 & 3,703 & 0,000 & 20 & 18122 & 15440000 & 1,17 & 6,03 & & 1,17 \\
\hline 8/1/2017 14:45 & 3,700 & 0 & 3,700 & 0,000 & & & & & & & \\
\hline $8 / 1 / 2017 \quad 15: 00$ & 3,703 & 0 & 3,703 & 0,000 & & & & & & & \\
\hline $8 / 1 / 2017 \quad 15: 15$ & 3,717 & 4 & 3,717 & 0,000 & & & & & & & \\
\hline $8 / 1 / 2017 \quad 15: 30$ & 3,826 & 7,2 & 3,728 & 0,098 & & & & & & 1,17 & \\
\hline $8 / 1 / 2017 \quad 15: 45$ & 3,974 & 3,2 & 3,738 & 0,235 & & & & & & & \\
\hline 8/1/2017 16:00 & 4,004 & 0 & 3,749 & 0,255 & & & & & & & \\
\hline $8 / 1 / 2017 \quad 16: 15$ & 4,123 & 0 & 3,759 & 0,363 & & & & & & & \\
\hline $8 / 1 / 2017 \quad 16: 30$ & 4,548 & 0 & 3,770 & 0,778 & & & & & & & \\
\hline 8/1/2017 $16: 45$ & 4,739 & 0 & 3,780 & 0,958 & & & & & & & \\
\hline 8/1/2017 17:00 & 4,765 & 0 & 3,791 & 0,974 & & & & & & & \\
\hline $8 / 1 / 2017 \quad 17: 15$ & 4,752 & 0 & 3,801 & 0,950 & & & & & & & \\
\hline $8 / 1 / 2017 \quad 17: 30$ & 4,918 & 0 & 3,812 & 1,106 & & & & & & & \\
\hline 8/1/2017 17:45 & 5,221 & 0 & 3,823 & 1,399 & & & & & & & \\
\hline 8/1/2017 18:00 & 5,147 & 0 & 3,833 & 1,314 & & & & & & & \\
\hline 8/1/2017 18:15 & 5,029 & 0 & 3,844 & 1,186 & & & & & & & \\
\hline $8 / 1 / 2017 \quad 18: 30$ & 4,891 & 0 & 3,854 & 1,037 & & & & & & & \\
\hline 8/1/2017 18:45 & 4,847 & 0 & 3,865 & 0,983 & & & & & & & \\
\hline 8/1/2017 19:00 & 4,778 & 0 & 3,875 & 0,903 & & & & & & & \\
\hline 8/1/2017 19:15 & 4,726 & 0 & 3,886 & 0,840 & & & & & & & \\
\hline 8/1/2017 19:30 & 4,653 & 0 & 3,896 & 0,757 & & & & & & & \\
\hline 8/1/2017 19:45 & 4,598 & 0 & 3,907 & 0,692 & & & & & & & \\
\hline 8/1/2017 20:00 & 4,548 & 0 & 3,917 & 0,631 & & & & & & & \\
\hline 8/1/2017 20:15 & 4,494 & 0 & 3,928 & 0,567 & & & & & & & \\
\hline
\end{tabular}




\begin{tabular}{|c|c|c|c|c|c|c|c|c|c|c|c|}
\hline Waktu & $\mathbf{Q}(\mathbf{m} 3 / \mathbf{s})$ & $\mathbf{P}$ & $\begin{array}{c}\text { Baseflow } \\
(\mathrm{m} 3 / \mathbf{s})\end{array}$ & $\begin{array}{c}\text { DRO } \\
(\mathbf{m} 3 / \mathbf{s})\end{array}$ & $\begin{array}{c}\text { Total } \\
\text { DRO } \\
(\mathrm{m} 3 / \mathbf{s}) \\
\end{array}$ & $\begin{array}{c}\text { Volume DRO } \\
(\mathrm{m} 3)\end{array}$ & $\begin{array}{l}\text { Luas } \\
\text { DTA } \\
(\mathrm{m} 2) \\
\end{array}$ & $\begin{array}{l}\text { Tebal } \\
\text { DRO } \\
(\mathbf{m m})\end{array}$ & $\begin{array}{c}\phi(\mathrm{mm} / \\
15 \\
\text { menit })\end{array}$ & $\begin{array}{c}\text { Hujan } \\
\text { efektif } \\
(\mathbf{m m})\end{array}$ & $\begin{array}{l}\text { Total } \\
\text { Hujan } \\
\text { Efetif }\end{array}$ \\
\hline 8/1/2017 20:30 & 4,449 & 0 & 3,938 & 0,511 & & & & & & & \\
\hline 8/1/2017 20:45 & 4,420 & 0 & 3,949 & 0,472 & & & & & & & \\
\hline $8 / 1 / 2017 \quad 21: 00$ & 4,400 & 0 & 3,959 & 0,441 & & & & & & & \\
\hline $8 / 1 / 2017 \quad 21: 15$ & 4,384 & 0 & 3,970 & 0,414 & & & & & & & \\
\hline $8 / 1 / 2017 \quad 21: 30$ & 4,372 & 0 & 3,980 & 0,392 & & & & & & & \\
\hline $8 / 1 / 2017 \quad 21: 45$ & 4,343 & 0 & 3,991 & 0,353 & & & & & & & \\
\hline 8/1/2017 22:00 & 4,315 & 0 & 4,001 & 0,314 & & & & & & & \\
\hline $8 / 1 / 2017 \quad 22: 15$ & 4,295 & 0 & 4,012 & 0,284 & & & & & & & \\
\hline $8 / 1 / 2017 \quad 22: 30$ & 4,264 & 0 & 4,022 & 0,241 & & & & & & & \\
\hline $8 / 1 / 2017 \quad 22: 45$ & 4,236 & 0 & 4,033 & 0,203 & & & & & & & \\
\hline 8/1/2017 23:00 & 4,216 & 0 & 4,043 & 0,173 & & & & & & & \\
\hline $8 / 1 / 2017 \quad 23: 15$ & 4,181 & 0 & 4,054 & 0,127 & & & & & & & \\
\hline 8/1/2017 23:30 & 4,157 & 0 & 4,064 & 0,093 & & & & & & & \\
\hline 8/1/2017 23:45 & 4,130 & 0 & 4,075 & 0,056 & & & & & & & \\
\hline 9/1/2017 0:00 & 4,119 & 0 & 4,085 & 0,034 & & & & & & & \\
\hline
\end{tabular}




\section{Lampiran 3. Perhitungan Hujan Efektif Gua Pindul}

Waktu awal hujan 14 Januari 2017 21:30

\begin{tabular}{|c|c|c|c|c|c|c|c|c|c|c|c|}
\hline Waktu & $\mathbf{Q}(\mathrm{m} 3 / \mathrm{s})$ & $\mathbf{P}$ & $\begin{array}{c}\text { Bas eflow } \\
(\mathrm{m} 3 / \mathrm{s})\end{array}$ & $\begin{array}{l}\text { DRO } \\
(\mathrm{m} 3 / \mathrm{s})\end{array}$ & $\begin{array}{l}\text { Total } \\
\text { DRO } \\
(\mathrm{m} 3 / \mathrm{s})\end{array}$ & $\begin{array}{c}\text { Volume } \\
\text { DRO } \\
\text { (m3) }\end{array}$ & $\begin{array}{l}\text { Luas DTA } \\
\quad(\mathrm{m} 2)\end{array}$ & $\begin{array}{l}\text { Tebal } \\
\text { DRO } \\
(\mathrm{mm})\end{array}$ & $\begin{array}{c}\phi(\mathrm{mm} / \\
15 \\
\text { menit })\end{array}$ & $\begin{array}{c}\text { Hujan } \\
\text { efektif } \\
(\mathbf{m m})\end{array}$ & $\begin{array}{c}\text { Total } \\
\text { Hujan } \\
\text { Efetif }\end{array}$ \\
\hline $14 / 1 / 2017 \quad 21: 30$ & 3,513 & 0,8 & 3,513 & 0,000 & 61 & 55.340 & 15.440 .000 & 3,58 & 5,71 & & 3,58 \\
\hline 14/1/2017 21:45 & 3,638 & 8 & 3,520 & 0,118 & & & & & & 2,29 & \\
\hline 14/1/2017 22:00 & 3,795 & 7 & 3,527 & 0,268 & & & & & & 1,29 & \\
\hline $14 / 1 / 2017 \quad 22: 15$ & 3,909 & 1,8 & 3,534 & 0,375 & & & & & & & \\
\hline $14 / 1 / 2017 \quad 22: 30$ & 4,310 & 0,8 & 3,541 & 0,769 & & & & & & & \\
\hline 14/1/2017 22:45 & 4,703 & 0,8 & 3,547 & 1,155 & & & & & & & \\
\hline 14/1/2017 23:00 & 4,759 & 0,4 & 3,554 & 1,204 & & & & & & & \\
\hline $14 / 1 / 2017 \quad 23: 15$ & 4,720 & 0,4 & 3,561 & 1,159 & & & & & & & \\
\hline $14 / 1 / 2017 \quad 23: 30$ & 4,885 & 1 & 3,568 & 1,317 & & & & & & & \\
\hline $14 / 1 / 2017 \quad 23: 45$ & 5,704 & 0,4 & 3,575 & 2,129 & & & & & & & \\
\hline 15/1/2017 $0: 00$ & 5,874 & 0,2 & 3,581 & 2,293 & & & & & & & \\
\hline $15 / 1 / 2017 \quad 0: 15$ & 5,753 & 0,2 & 3,588 & 2,165 & & & & & & & \\
\hline $15 / 1 / 2017 \quad 0: 30$ & 5,615 & 0,2 & 3,595 & 2,020 & & & & & & & \\
\hline $15 / 1 / 2017 \quad 0: 45$ & 5,576 & 0,2 & 3,602 & 1,974 & & & & & & & \\
\hline $\begin{array}{ll}15 / 1 / 2017 & 1: 00\end{array}$ & 5,503 & 0 & 3,609 & 1,894 & & & & & & & \\
\hline $15 / 1 / 2017 \quad 1: 15$ & 5,445 & 0 & 3,615 & 1,830 & & & & & & & \\
\hline $15 / 1 / 2017 \quad 1: 30$ & 5,383 & 0 & 3,622 & 1,761 & & & & & & & \\
\hline 15/1/2017 1:45 & 5,336 & 0 & 3,629 & 1,707 & & & & & & & \\
\hline $15 / 1 / 2017 \quad 2: 00$ & 5,238 & 0 & 3,636 & 1,602 & & & & & & & \\
\hline $15 / 1 / 2017 \quad 2: 15$ & 5,164 & 0 & 3,643 & 1,521 & & & & & & & \\
\hline $15 / 1 / 2017 \quad 2: 30$ & 5,123 & 0,2 & 3,649 & 1,473 & & & & & & & \\
\hline $15 / 1 / 2017 \quad 2: 45$ & 5,059 & 0 & 3,656 & 1,403 & & & & & & & \\
\hline $15 / 1 / 2017 \quad 3: 00$ & 4,996 & 0 & 3,663 & 1,333 & & & & & & & \\
\hline
\end{tabular}




\begin{tabular}{|c|c|c|c|c|c|c|c|c|c|c|c|}
\hline Waktu & $Q(\mathrm{~m} 3 / \mathrm{s})$ & $\mathbf{P}$ & $\begin{array}{c}\text { Baseflow } \\
(\mathrm{m} 3 / \mathrm{s})\end{array}$ & $\begin{array}{c}\text { DRO } \\
(\mathrm{m} 3 / \mathrm{s})\end{array}$ & $\begin{array}{l}\text { Total } \\
\text { DRO } \\
(\mathrm{m} 3 / \mathrm{s})\end{array}$ & $\begin{array}{c}\text { Volume } \\
\text { DRO } \\
\text { (m3) }\end{array}$ & $\begin{array}{l}\text { Luas DTA } \\
\quad(\mathbf{m} 2)\end{array}$ & $\begin{array}{l}\text { Tebal } \\
\text { DRO } \\
(\mathrm{mm})\end{array}$ & $\begin{array}{c}\phi(\mathrm{mm} / \\
15 \\
\text { menit })\end{array}$ & $\begin{array}{c}\begin{array}{c}\text { Hujan } \\
\text { efektif } \\
(\mathrm{mm})\end{array} \\
\end{array}$ & $\begin{array}{l}\text { Total } \\
\text { Hujan } \\
\text { Efetif }\end{array}$ \\
\hline 15/1/2017 $3: 15$ & 4,920 & 0 & 3,670 & 1,251 & & & & & & & \\
\hline 15/1/2017 $3: 30$ & 4,907 & 0,2 & 3,677 & 1,230 & & & & & & & \\
\hline 15/1/2017 3:45 & 4,872 & 0 & 3,683 & 1,188 & & & & & & & \\
\hline 15/1/2017 4:00 & 4,819 & 0,2 & 3,690 & 1,129 & & & & & & & \\
\hline 15/1/2017 $4: 15$ & 4,785 & 0 & 3,697 & 1,088 & & & & & & & \\
\hline 15/1/2017 4:30 & 4,750 & 0 & 3,704 & 1,046 & & & & & & & \\
\hline 15/1/2017 $4: 45$ & 4,694 & 0 & 3,711 & 0,984 & & & & & & & \\
\hline 15/1/2017 5:00 & 4,707 & 0 & 3,717 & 0,990 & & & & & & & \\
\hline 15/1/2017 5:15 & 4,643 & 0 & 3,724 & 0,919 & & & & & & & \\
\hline 15/1/2017 5:30 & 4,631 & 0 & 3,731 & 0,899 & & & & & & & \\
\hline 15/1/2017 $5: 45$ & 4,588 & 0 & 3,738 & 0,851 & & & & & & & \\
\hline 15/1/2017 6:00 & 4,567 & 0 & 3,745 & 0,823 & & & & & & & \\
\hline 15/1/2017 6:15 & 4,542 & 0 & 3,751 & 0,791 & & & & & & & \\
\hline 15/1/2017 6:30 & 4,538 & 0 & 3,758 & 0,780 & & & & & & & \\
\hline 15/1/2017 $6: 45$ & 4,493 & 0 & 3,765 & 0,728 & & & & & & & \\
\hline 15/1/2017 7:00 & 4,468 & 0 & 3,772 & 0,696 & & & & & & & \\
\hline 15/1/2017 7:15 & 4,468 & 0 & 3,779 & 0,689 & & & & & & & \\
\hline 15/1/2017 7:30 & 4,456 & 0 & 3,785 & 0,670 & & & & & & & \\
\hline 15/1/2017 $7: 45$ & 4,419 & 0 & 3,792 & 0,627 & & & & & & & \\
\hline 15/1/2017 8:00 & 4,423 & 0 & 3,799 & 0,624 & & & & & & & \\
\hline 15/1/2017 $8: 15$ & 4,423 & 0 & 3,806 & 0,617 & & & & & & & \\
\hline 15/1/2017 $8: 30$ & 4,403 & 0 & 3,813 & 0,590 & & & & & & & \\
\hline 15/1/2017 $8: 45$ & 4,358 & 0 & 3,819 & 0,539 & & & & & & & \\
\hline 15/1/2017 9:00 & 4,354 & 0 & 3,826 & 0,528 & & & & & & & \\
\hline 15/1/2017 9:15 & 4,362 & 0 & 3,833 & 0,529 & & & & & & & \\
\hline 15/1/2017 9:30 & 4,358 & 0 & 3,840 & 0,518 & & & & & & & \\
\hline
\end{tabular}




\begin{tabular}{|c|c|c|c|c|c|c|c|c|c|c|c|}
\hline Waktu & $Q(\mathrm{~m} 3 / \mathbf{s})$ & $\mathbf{P}$ & $\begin{array}{c}\text { Baseflow } \\
(\mathrm{m} 3 / \mathrm{s})\end{array}$ & $\begin{array}{c}\text { DRO } \\
(\mathrm{m} 3 / \mathrm{s})\end{array}$ & $\begin{array}{l}\text { Total } \\
\text { DRO } \\
(\mathrm{m} 3 / \mathrm{s})\end{array}$ & $\begin{array}{c}\text { Volume } \\
\text { DRO } \\
\text { (m3) }\end{array}$ & $\begin{array}{l}\text { Luas DTA } \\
\quad(\mathbf{m} 2)\end{array}$ & $\begin{array}{l}\text { Tebal } \\
\text { DRO } \\
(\mathrm{mm})\end{array}$ & $\begin{array}{c}\phi(\mathrm{mm} / \\
15 \\
\text { menit })\end{array}$ & $\begin{array}{c}\begin{array}{c}\text { Hujan } \\
\text { efektif } \\
(\mathrm{mm})\end{array} \\
\end{array}$ & $\begin{array}{l}\text { Total } \\
\text { Hujan } \\
\text { Efetif }\end{array}$ \\
\hline 15/1/2017 9:45 & 4,350 & 0 & 3,847 & 0,503 & & & & & & & \\
\hline 15/1/2017 10:00 & 4,330 & 0 & 3,853 & 0,476 & & & & & & & \\
\hline 15/1/2017 10:15 & 4,342 & 0 & 3,860 & 0,482 & & & & & & & \\
\hline 15/1/2017 10:30 & 4,318 & 0 & 3,867 & 0,451 & & & & & & & \\
\hline 15/1/2017 10:45 & 4,326 & 0 & 3,874 & 0,452 & & & & & & & \\
\hline 15/1/2017 11:00 & 4,310 & 0 & 3,881 & 0,429 & & & & & & & \\
\hline 15/1/2017 11:15 & 4,298 & 0 & 3,887 & 0,410 & & & & & & & \\
\hline 15/1/2017 11:30 & 4,278 & 0 & 3,894 & 0,384 & & & & & & & \\
\hline 15/1/2017 11:45 & 4,286 & 0 & 3,901 & 0,385 & & & & & & & \\
\hline 15/1/2017 12:00 & 4,278 & 0 & 3,908 & 0,370 & & & & & & & \\
\hline 15/1/2017 12:15 & 4,282 & 0 & 3,915 & 0,367 & & & & & & & \\
\hline 15/1/2017 $12: 30$ & 4,270 & 0 & 3,921 & 0,348 & & & & & & & \\
\hline 15/1/2017 12:45 & 4,266 & 0 & 3,928 & 0,338 & & & & & & & \\
\hline 15/1/2017 13:00 & 4,246 & 0 & 3,935 & 0,311 & & & & & & & \\
\hline 15/1/2017 13:15 & 4,254 & 0 & 3,942 & 0,312 & & & & & & & \\
\hline 15/1/2017 13:30 & 4,230 & 0 & 3,949 & 0,282 & & & & & & & \\
\hline 15/1/2017 13:45 & 4,234 & 0 & 3,955 & 0,279 & & & & & & & \\
\hline 15/1/2017 14:00 & 4,183 & 0 & 3,962 & 0,221 & & & & & & & \\
\hline 15/1/2017 14:15 & 4,199 & 0 & 3,969 & 0,230 & & & & & & & \\
\hline 15/1/2017 14:30 & 4,199 & 0 & 3,976 & 0,223 & & & & & & & \\
\hline 15/1/2017 14:45 & 4,191 & 0 & 3,983 & 0,208 & & & & & & & \\
\hline 15/1/2017 15:00 & 4,179 & 0 & 3,989 & 0,190 & & & & & & & \\
\hline 15/1/2017 15:15 & 4,168 & 0 & 3,996 & 0,171 & & & & & & & \\
\hline 15/1/2017 15:30 & 4,168 & 0 & 4,003 & 0,165 & & & & & & & \\
\hline 15/1/2017 15:45 & 4,144 & 0 & 4,010 & 0,134 & & & & & & & \\
\hline 15/1/2017 16:00 & 4,152 & 0 & 4,017 & 0,135 & & & & & & & \\
\hline
\end{tabular}




\begin{tabular}{|c|c|c|c|c|c|c|c|c|c|c|c|}
\hline Waktu & $\mathbf{Q}(\mathrm{m} 3 / \mathrm{s})$ & $\mathbf{P}$ & $\begin{array}{c}\text { Baseflow } \\
(\mathbf{m} 3 / \mathbf{s})\end{array}$ & $\begin{array}{c}\text { DRO } \\
(\mathbf{m} 3 / \mathbf{s})\end{array}$ & $\begin{array}{l}\text { Total } \\
\text { DRO } \\
(\mathrm{m} 3 / \mathrm{s})\end{array}$ & $\begin{array}{c}\text { Volume } \\
\text { DRO } \\
\text { (m3) }\end{array}$ & $\begin{array}{c}\text { Luas DTA } \\
\quad(\mathrm{m} 2)\end{array}$ & $\begin{array}{l}\text { Tebal } \\
\text { DRO } \\
(\mathbf{m m})\end{array}$ & $\begin{array}{c}\phi(\mathrm{mm} / \\
15 \\
\text { menit) }\end{array}$ & $\begin{array}{c}\text { Hujan } \\
\text { efek tif } \\
(\mathrm{mm})\end{array}$ & $\begin{array}{l}\text { Total } \\
\text { Hujan } \\
\text { Efetif }\end{array}$ \\
\hline $15 / 1 / 2017 \quad 16: 15$ & 4,144 & 0 & 4,023 & 0,121 & & & & & & & \\
\hline $15 / 1 / 2017 \quad 16: 30$ & 4,109 & 0 & 4,030 & 0,079 & & & & & & & \\
\hline $\begin{array}{lll}15 / 1 / 2017 & 16: 45\end{array}$ & 4,102 & 0 & 4,037 & 0,065 & & & & & & & \\
\hline 15/1/2017 $17: 00$ & 4,094 & 0 & 4,044 & 0,050 & & & & & & & \\
\hline 15/1/2017 17:15 & 4,109 & 0 & 4,051 & 0,059 & & & & & & & \\
\hline $15 / 1 / 2017 \quad 17: 30$ & 4,094 & 0,2 & 4,057 & 0,037 & & & & & & & \\
\hline $15 / 1 / 2017 \quad 17: 45$ & 4,090 & 0 & 4,064 & 0,026 & & & & & & & \\
\hline
\end{tabular}




\section{Lampiran 3. Perhitungan Hujan Efektif Gua Pindul}

Waktu awal hujan 3 Februari 2017 02:45

\begin{tabular}{|c|c|c|c|c|c|c|c|c|c|c|c|}
\hline Waktu & $\mathrm{Q}(\mathrm{m} 3 / \mathrm{s})$ & $\mathbf{P}$ & $\begin{array}{c}\text { Baseflow } \\
(\mathrm{m} 3 / \mathrm{s})\end{array}$ & $\begin{array}{c}\text { DRO } \\
(\mathrm{m} 3 / \mathrm{s})\end{array}$ & $\begin{array}{c}\text { Total } \\
\text { DRO } \\
(\mathrm{m} 3 / \mathbf{s})\end{array}$ & $\begin{array}{c}\text { Volume } \\
\text { DRO } \\
\text { (m3) }\end{array}$ & $\begin{array}{l}\text { Luas } \\
\text { DTA } \\
(\mathbf{m} 2)\end{array}$ & $\begin{array}{l}\text { Tebal } \\
\text { DRO } \\
(\mathrm{mm})\end{array}$ & $\begin{array}{c}\phi(\mathrm{mm} / \\
15 \\
\text { menit })\end{array}$ & $\begin{array}{c}\text { Hujan } \\
\text { efektif } \\
(\mathbf{m m})\end{array}$ & $\begin{array}{c}\text { Total } \\
\text { Hujan } \\
\text { Efetif }\end{array}$ \\
\hline $3 / 2 / 2017 \quad 0: 00$ & 4,012 & 0 & 4,012 & 0,000 & 148 & 133155 & 15440000 & 8,62 & 2,79 & & 8,62 \\
\hline $3 / 2 / 2017 \quad 0: 15$ & 4,012 & 0,2 & 4,012 & 0,000 & & & & & & & \\
\hline $3 / 2 / 2017 \quad 0: 30$ & 4,004 & 0 & 4,004 & 0,000 & & & & & & & \\
\hline $3 / 2 / 2017 \quad 0: 45$ & 4,004 & 2,2 & 4,004 & 0,000 & & & & & & & \\
\hline $3 / 2 / 2017 \quad 1: 00$ & 4,004 & 1,4 & 4,004 & 0,000 & & & & & & & \\
\hline $3 / 2 / 2017 \quad 1: 15$ & 4,004 & 0 & 4,004 & 0,000 & & & & & & & \\
\hline $3 / 2 / 2017 \quad 1: 30$ & 4,004 & 0,8 & 4,004 & 0,000 & & & & & & & \\
\hline $3 / 2 / 2017 \quad 1: 45$ & 4,015 & 1,6 & 4,015 & 0,000 & & & & & & & \\
\hline $3 / 2 / 2017 \quad 2: 00$ & 4,004 & 0 & 4,004 & 0,000 & & & & & & & \\
\hline $3 / 2 / 2017 \quad 2: 15$ & 4,012 & 0,2 & 4,012 & 0,000 & & & & & & & \\
\hline $3 / 2 / 2017 \quad 2: 30$ & 4,015 & 0 & 4,015 & 0,000 & & & & & & & \\
\hline $3 / 2 / 2017 \quad 2: 45$ & 4,050 & 6,8 & 4,017 & 0,033 & & & & & & 4,01 & \\
\hline $3 / 2 / 2017 \quad 3: 00$ & 4,220 & 5,2 & 4,018 & 0,202 & & & & & & 2,41 & \\
\hline $3 / 2 / 2017 \quad 3: 15$ & 4,343 & 5 & 4,019 & 0,325 & & & & & & 2,21 & \\
\hline $3 / 2 / 2017 \quad 3: 30$ & 4,747 & 1,8 & 4,020 & 0,727 & & & & & & & \\
\hline $3 / 2 / 2017 \quad 3: 45$ & 7,265 & 1,2 & 4,021 & 3,244 & & & & & & & \\
\hline $3 / 2 / 2017 \quad 4: 00$ & 10,524 & 1 & 4,022 & 6,502 & & & & & & & \\
\hline $3 / 2 / 2017 \quad 4: 15$ & 12,348 & 0,8 & 4,023 & 8,325 & & & & & & & \\
\hline $3 / 2 / 2017 \quad 4: 30$ & 12,867 & 0,4 & 4,024 & 8,843 & & & & & & & \\
\hline $3 / 2 / 2017 \quad 4: 45$ & 12,738 & 0,4 & 4,026 & 8,713 & & & & & & & \\
\hline $3 / 2 / 2017 \quad 5: 00$ & 12,429 & 0,2 & 4,027 & 8,402 & & & & & & & \\
\hline $3 / 2 / 2017 \quad 5: 15$ & 12,020 & 0,4 & 4,028 & 7,992 & & & & & & & \\
\hline $3 / 2 / 2017 \quad 5: 30$ & 11,595 & 0,2 & 4,029 & 7,566 & & & & & & & \\
\hline $3 / 2 / 2017 \quad 5: 45$ & 10,943 & 0 & 4,030 & 6,913 & & & & & & & \\
\hline
\end{tabular}




\begin{tabular}{|c|c|c|c|c|c|c|c|c|c|c|c|}
\hline Waktu & $Q(\mathbf{m} 3 / \mathbf{s})$ & $\mathbf{P}$ & $\begin{array}{c}\text { Bas eflow } \\
(\mathrm{m} 3 / \mathrm{s})\end{array}$ & $\begin{array}{c}\text { DRO } \\
(\mathrm{m} 3 / \mathrm{s})\end{array}$ & $\begin{array}{c}\text { Total } \\
\text { DRO } \\
(\mathrm{m} 3 / \mathbf{s}) \\
\end{array}$ & $\begin{array}{c}\text { Volume } \\
\text { DRO } \\
(\mathrm{m3}) \\
\end{array}$ & $\begin{array}{l}\text { Luas } \\
\text { DTA } \\
(\mathrm{m} 2) \\
\end{array}$ & $\begin{array}{l}\text { Tebal } \\
\text { DRO } \\
(\mathrm{mm}) \\
\end{array}$ & $\begin{array}{c}\phi(\mathrm{mm} / \\
15 \\
\text { menit })\end{array}$ & $\begin{array}{c}\text { Hujan } \\
\text { efektif } \\
(\mathrm{mm})\end{array}$ & $\begin{array}{r}\text { Total } \\
\text { Hujan } \\
\text { Efetif } \\
\end{array}$ \\
\hline $3 / 2 / 2017 \quad 6: 00$ & 10,281 & 0 & 4,031 & 6,249 & & & & & & & \\
\hline $3 / 2 / 2017 \quad 6: 15$ & 9,597 & 0 & 4,032 & 5,565 & & & & & & & \\
\hline $3 / 2 / 2017 \quad 6: 30$ & 9,020 & 0 & 4,034 & 4,986 & & & & & & & \\
\hline $3 / 2 / 2017 \quad 6: 45$ & 8,503 & 0 & 4,035 & 4,468 & & & & & & & \\
\hline $3 / 2 / 2017 \quad 7: 00$ & 8,016 & 0 & 4,036 & 3,980 & & & & & & & \\
\hline $3 / 2 / 2017 \quad 7: 15$ & 7,649 & 0 & 4,037 & 3,612 & & & & & & & \\
\hline $3 / 2 / 2017 \quad 7: 30$ & 7,385 & 0 & 4,038 & 3,347 & & & & & & & \\
\hline $3 / 2 / 2017 \quad 7: 45$ & 7,076 & 0 & 4,039 & 3,037 & & & & & & & \\
\hline $3 / 2 / 2017 \quad 8: 00$ & 6,805 & 0 & 4,040 & 2,765 & & & & & & & \\
\hline $3 / 2 / 2017 \quad 8: 15$ & 6,598 & 0 & 4,041 & 2,556 & & & & & & & \\
\hline $3 / 2 / 2017 \quad 8: 30$ & 6,417 & 0 & 4,043 & 2,374 & & & & & & & \\
\hline $3 / 2 / 2017 \quad 8: 45$ & 6,245 & 0 & 4,044 & 2,201 & & & & & & & \\
\hline 3/2/2017 9:00 & 6,097 & 0 & 4,045 & 2,052 & & & & & & & \\
\hline $3 / 2 / 2017 \quad 9: 15$ & 5,973 & 0 & 4,046 & 1,927 & & & & & & & \\
\hline $3 / 2 / 2017 \quad 9: 30$ & 5,836 & 0 & 4,047 & 1,788 & & & & & & & \\
\hline $3 / 2 / 2017 \quad 9: 45$ & 5,735 & 0 & 4,048 & 1,687 & & & & & & & \\
\hline $3 / 2 / 2017 \quad 10: 00$ & 5,622 & 0 & 4,049 & 1,572 & & & & & & & \\
\hline $3 / 2 / 2017 \quad 10: 15$ & 5,539 & 0 & 4,050 & 1,488 & & & & & & & \\
\hline $3 / 2 / 2017 \quad 10: 30$ & 5,447 & 0 & 4,052 & 1,396 & & & & & & & \\
\hline $3 / 2 / 2017 \quad 10: 45$ & 5,376 & 0 & 4,053 & 1,323 & & & & & & & \\
\hline 3/2/2017 11:00 & 5,300 & 0 & 4,054 & 1,246 & & & & & & & \\
\hline $3 / 2 / 2017 \quad 11: 15$ & 5,221 & 0 & 4,055 & 1,166 & & & & & & & \\
\hline $3 / 2 / 2017 \quad 11: 30$ & 5,138 & 0 & 4,056 & 1,082 & & & & & & & \\
\hline 3/2/2017 11:45 & 5,088 & 0 & 4,057 & 1,031 & & & & & & & \\
\hline 3/2/2017 12:00 & 5,029 & 0,2 & 4,058 & 0,971 & & & & & & & \\
\hline $3 / 2 / 2017 \quad 12: 15$ & 4,975 & 0 & 4,060 & 0,916 & & & & & & & \\
\hline
\end{tabular}




\begin{tabular}{|c|c|c|c|c|c|c|c|c|c|c|c|}
\hline Waktu & $Q(\mathbf{m} 3 / \mathbf{s})$ & $\mathbf{P}$ & $\begin{array}{c}\text { Baseflow } \\
(\mathrm{m} 3 / \mathrm{s})\end{array}$ & $\begin{array}{c}\text { DRO } \\
(\mathrm{m} 3 / \mathbf{s})\end{array}$ & $\begin{array}{c}\text { Total } \\
\text { DRO } \\
(\mathrm{m} 3 / \mathbf{s}) \\
\end{array}$ & $\begin{array}{c}\text { Volume } \\
\text { DRO } \\
(\mathrm{m3}) \\
\end{array}$ & $\begin{array}{l}\text { Luas } \\
\text { DTA } \\
(\mathrm{m} 2) \\
\end{array}$ & $\begin{array}{l}\text { Tebal } \\
\text { DRO } \\
(\mathrm{mm}) \\
\end{array}$ & $\begin{array}{c}\phi(\mathrm{mm} / \\
15 \\
\text { menit })\end{array}$ & $\begin{array}{c}\text { Hujan } \\
\text { efektif } \\
(\mathrm{mm})\end{array}$ & $\begin{array}{r}\text { Total } \\
\text { Hujan } \\
\text { Efetif } \\
\end{array}$ \\
\hline $3 / 2 / 2017 \quad 12: 30$ & 4,927 & 0 & 4,061 & 0,866 & & & & & & & \\
\hline $3 / 2 / 2017 \quad 12: 45$ & 4,882 & 0 & 4,062 & 0,821 & & & & & & & \\
\hline 3/2/2017 13:00 & 4,843 & 0 & 4,063 & 0,780 & & & & & & & \\
\hline $3 / 2 / 2017 \quad 13: 15$ & 4,799 & 0 & 4,064 & 0,735 & & & & & & & \\
\hline $3 / 2 / 2017 \quad 13: 30$ & 4,756 & 0 & 4,065 & 0,691 & & & & & & & \\
\hline $3 / 2 / 2017 \quad 13: 45$ & 4,722 & 0 & 4,066 & 0,655 & & & & & & & \\
\hline $3 / 2 / 2017 \quad 14: 00$ & 4,687 & 0 & 4,067 & 0,620 & & & & & & & \\
\hline $3 / 2 / 2017 \quad 14: 15$ & 4,675 & 0 & 4,069 & 0,606 & & & & & & & \\
\hline $3 / 2 / 2017 \quad 14: 30$ & 4,632 & 0 & 4,070 & 0,563 & & & & & & & \\
\hline $3 / 2 / 2017 \quad 14: 45$ & 4,615 & 0 & 4,071 & 0,545 & & & & & & & \\
\hline 3/2/2017 15:00 & 4,577 & 0 & 4,072 & 0,506 & & & & & & & \\
\hline $3 / 2 / 2017 \quad 15: 15$ & 4,548 & 0 & 4,073 & 0,475 & & & & & & & \\
\hline $3 / 2 / 2017 \quad 15: 30$ & 4,536 & 0 & 4,074 & 0,462 & & & & & & & \\
\hline $3 / 2 / 2017 \quad 15: 45$ & 4,507 & 0 & 4,075 & 0,431 & & & & & & & \\
\hline 3/2/2017 16:00 & 4,490 & 0 & 4,076 & 0,414 & & & & & & & \\
\hline $3 / 2 / 2017 \quad 16: 15$ & 4,465 & 0 & 4,078 & 0,388 & & & & & & & \\
\hline $3 / 2 / 2017 \quad 16: 30$ & 4,449 & 0 & 4,079 & 0,370 & & & & & & & \\
\hline 3/2/2017 $16: 45$ & 4,433 & 0 & 4,080 & 0,353 & & & & & & & \\
\hline 3/2/2017 17:00 & 4,412 & 0 & 4,081 & 0,331 & & & & & & & \\
\hline $3 / 2 / 2017 \quad 17: 15$ & 4,400 & 0,2 & 4,082 & 0,318 & & & & & & & \\
\hline $3 / 2 / 2017 \quad 17: 30$ & 4,392 & 0 & 4,083 & 0,309 & & & & & & & \\
\hline $3 / 2 / 2017 \quad 17: 45$ & 4,388 & 1,2 & 4,084 & 0,304 & & & & & & & \\
\hline $3 / 2 / 2017 \quad 18: 00$ & 4,384 & 0 & 4,085 & 0,298 & & & & & & & \\
\hline $3 / 2 / 2017 \quad 18: 15$ & 4,376 & 0 & 4,087 & 0,289 & & & & & & & \\
\hline $3 / 2 / 2017 \quad 18: 30$ & 4,360 & 0 & 4,088 & 0,272 & & & & & & & \\
\hline $3 / 2 / 2017 \quad 18: 45$ & 4,347 & 0 & 4,089 & 0,259 & & & & & & & \\
\hline
\end{tabular}




\begin{tabular}{|c|c|c|c|c|c|c|c|c|c|c|c|}
\hline Waktu & $Q(\mathbf{m} 3 / \mathbf{s})$ & $\mathbf{P}$ & $\begin{array}{c}\text { Bas eflow } \\
(\mathrm{m} 3 / \mathrm{s})\end{array}$ & $\begin{array}{c}\text { DRO } \\
(\mathrm{m} 3 / \mathrm{s})\end{array}$ & $\begin{array}{c}\text { Total } \\
\text { DRO } \\
(\mathrm{m} 3 / \mathbf{s}) \\
\end{array}$ & $\begin{array}{c}\text { Volume } \\
\text { DRO } \\
(\mathrm{m3}) \\
\end{array}$ & $\begin{array}{l}\text { Luas } \\
\text { DTA } \\
(\mathrm{m} 2) \\
\end{array}$ & $\begin{array}{l}\text { Tebal } \\
\text { DRO } \\
(\mathrm{mm}) \\
\end{array}$ & $\begin{array}{c}\phi(\mathrm{mm} / \\
15 \\
\text { menit }) \\
\end{array}$ & $\begin{array}{c}\text { Hujan } \\
\text { efektif } \\
(\mathrm{mm})\end{array}$ & $\begin{array}{r}\text { Total } \\
\text { Hujan } \\
\text { Efetif } \\
\end{array}$ \\
\hline $3 / 2 / 2017 \quad 19: 00$ & 4,343 & 0 & 4,090 & 0,253 & & & & & & & \\
\hline $3 / 2 / 2017 \quad 19: 15$ & 4,335 & 0 & 4,091 & 0,244 & & & & & & & \\
\hline $3 / 2 / 2017 \quad 19: 30$ & 4,311 & 0 & 4,092 & 0,219 & & & & & & & \\
\hline $3 / 2 / 2017 \quad 19: 45$ & 4,299 & 0 & 4,093 & 0,206 & & & & & & & \\
\hline $3 / 2 / 2017 \quad 20: 00$ & 4,291 & 0 & 4,095 & 0,197 & & & & & & & \\
\hline $3 / 2 / 2017 \quad 20: 15$ & 4,291 & 0 & 4,096 & 0,196 & & & & & & & \\
\hline $3 / 2 / 2017 \quad 20: 30$ & 4,271 & 0 & 4,097 & 0,175 & & & & & & & \\
\hline $3 / 2 / 2017 \quad 20: 45$ & 4,268 & 0 & 4,098 & 0,170 & & & & & & & \\
\hline 3/2/2017 21:00 & 4,240 & 0 & 4,099 & 0,141 & & & & & & & \\
\hline $3 / 2 / 2017 \quad 21: 15$ & 4,232 & 0 & 4,100 & 0,132 & & & & & & & \\
\hline $3 / 2 / 2017 \quad 21: 30$ & 4,224 & 0 & 4,101 & 0,123 & & & & & & & \\
\hline 3/2/2017 21:45 & 4,208 & 0 & 4,102 & 0,106 & & & & & & & \\
\hline 3/2/2017 22:00 & 4,204 & 0 & 4,104 & 0,101 & & & & & & & \\
\hline $3 / 2 / 2017 \quad 22: 15$ & 4,204 & 0 & 4,105 & 0,100 & & & & & & & \\
\hline $3 / 2 / 2017 \quad 22: 30$ & 4,177 & 0 & 4,106 & 0,071 & & & & & & & \\
\hline $3 / 2 / 2017 \quad 22: 45$ & 4,169 & 0,2 & 4,107 & 0,062 & & & & & & & \\
\hline 3/2/2017 23:00 & 4,169 & 0 & 4,108 & 0,061 & & & & & & & \\
\hline $3 / 2 / 2017 \quad 23: 15$ & 4,157 & 0 & 4,109 & 0,048 & & & & & & & \\
\hline $3 / 2 / 2017 \quad 23: 30$ & 4,154 & 0 & 4,110 & 0,043 & & & & & & & \\
\hline $3 / 2 / 2017 \quad 23: 45$ & 4,138 & 0 & 4,111 & 0,027 & & & & & & & \\
\hline 4/2/2017 0:00 & 4,134 & 0 & 4,113 & 0,022 & & & & & & & \\
\hline 4/2/2017 $0: 15$ & 4,134 & 0 & 4,114 & 0,020 & & & & & & & \\
\hline
\end{tabular}




\section{Lampiran 3. Perhitungan Hujan Efektif Gua Pindul}

Waktu awal hujan 28 Februari 2017 20:30

\begin{tabular}{|c|c|c|c|c|c|c|c|c|c|c|c|}
\hline Waktu & $Q(\mathbf{m} 3 / \mathbf{s})$ & $\mathbf{P}$ & $\begin{array}{c}\text { Baseflow } \\
(\mathrm{m} 3 / \mathrm{s})\end{array}$ & $\begin{array}{c}\text { DRO } \\
(\mathrm{m} 3 / \mathrm{s})\end{array}$ & $\begin{array}{c}\text { Total } \\
\text { DRO } \\
(\mathrm{m} 3 / \mathrm{s})\end{array}$ & $\begin{array}{c}\text { Volume } \\
\text { DRO } \\
\text { (m3) }\end{array}$ & $\begin{array}{l}\text { Luas DTA } \\
\quad(\mathbf{m} 2)\end{array}$ & $\begin{array}{l}\text { Tebal } \\
\text { DRO } \\
(\mathrm{mm})\end{array}$ & $\begin{array}{c}\phi(\mathrm{mm} / \\
15 \\
\text { menit })\end{array}$ & $\begin{array}{l}\text { Hujan } \\
\text { efektif } \\
(\mathrm{mm})\end{array}$ & $\begin{array}{l}\text { Total } \\
\text { Hujan } \\
\text { Efetif }\end{array}$ \\
\hline 28/2/2017 19:45 & 3,929 & 0 & 3,929 & 0,000 & 30,30 & 27.268 & 15.440 .000 & 1,77 & 6,63 & & 1,77 \\
\hline 28/2/2017 20:00 & 3,929 & 0 & 3,929 & 0,000 & & & & & & & \\
\hline $28 / 2 / 2017 \quad 20: 15$ & 3,929 & 0 & 3,929 & 0,000 & & & & & & & \\
\hline 28/2/2017 20:30 & 3,929 & 2 & 3,938 & 0,000 & & & & & & & \\
\hline $28 / 2 / 2017 \quad 20: 45$ & 3,936 & 8,4 & 3,946 & 0,000 & & & & & & 1,77 & \\
\hline 28/2/2017 21:00 & 3,959 & 5,8 & 3,954 & 0,004 & & & & & & & \\
\hline $28 / 2 / 2017 \quad 21: 15$ & 3,997 & 2,4 & 3,963 & 0,034 & & & & & & & \\
\hline 28/2/2017 21:30 & 4,019 & 0,4 & 3,971 & 0,048 & & & & & & & \\
\hline $28 / 2 / 2017 \quad 21: 45$ & 4,073 & 0,4 & 3,980 & 0,093 & & & & & & & \\
\hline $28 / 2 / 2017 \quad 22: 00$ & 4,380 & 0 & 3,988 & 0,391 & & & & & & & \\
\hline $28 / 2 / 2017 \quad 22: 15$ & 4,636 & 0 & 3,997 & 0,639 & & & & & & & \\
\hline 28/2/2017 22:30 & 4,713 & 0 & 4,005 & 0,708 & & & & & & & \\
\hline 28/2/2017 22:45 & 4,743 & 0 & 4,014 & 0,729 & & & & & & & \\
\hline $28 / 2 / 2017 \quad 23: 00$ & 4,922 & 0 & 4,022 & 0,900 & & & & & & & \\
\hline $28 / 2 / 2017 \quad 23: 15$ & 5,404 & 0 & 4,031 & 1,373 & & & & & & & \\
\hline $28 / 2 / 2017 \quad 23: 30$ & 5,912 & 0 & 4,039 & 1,872 & & & & & & & \\
\hline 28/2/2017 23:45 & 5,927 & 0 & 4,048 & 1,879 & & & & & & & \\
\hline 1/3/2017 0:00 & 5,841 & 0 & 4,056 & 1,784 & & & & & & & \\
\hline $1 / 3 / 2017 \quad 0: 15$ & 5,740 & 0 & 4,065 & 1,675 & & & & & & & \\
\hline $1 / 3 / 2017 \quad 0: 30$ & 5,646 & 0 & 4,073 & 1,573 & & & & & & & \\
\hline $1 / 3 / 2017 \quad 0: 45$ & 5,558 & 0 & 4,082 & 1,476 & & & & & & & \\
\hline $1 / 3 / 2017 \quad 1: 00$ & 5,438 & 0 & 4,090 & 1,347 & & & & & & & \\
\hline $1 / 3 / 2017 \quad 1: 15$ & 5,362 & 0 & 4,099 & 1,263 & & & & & & & \\
\hline $1 / 3 / 2017 \quad 1: 30$ & 5,286 & 0 & 4,107 & 1,179 & & & & & & & \\
\hline
\end{tabular}




\begin{tabular}{|c|c|c|c|c|c|c|c|c|c|c|c|}
\hline Waktu & $\mathrm{Q}(\mathrm{m} 3 / \mathrm{s})$ & $\mathbf{P}$ & $\begin{array}{c}\text { Baseflow } \\
(\mathrm{m} 3 / \mathrm{s})\end{array}$ & $\begin{array}{c}\text { DRO } \\
(\mathrm{m} 3 / \mathrm{s})\end{array}$ & $\begin{array}{c}\text { Total } \\
\text { DRO } \\
\text { (m3/s) } \\
\end{array}$ & $\begin{array}{c}\text { Volume } \\
\text { DRO } \\
(\mathrm{m3}) \\
\end{array}$ & $\begin{array}{l}\text { Luas DTA } \\
\quad(\mathbf{m} 2)\end{array}$ & $\begin{array}{l}\text { Tebal } \\
\text { DRO } \\
(\mathrm{mm})\end{array}$ & $\begin{array}{c}\phi(\mathrm{mm} / \\
15 \\
\text { menit })\end{array}$ & $\begin{array}{c}\text { Hujan } \\
\text { efektif } \\
(\mathrm{mm})\end{array}$ & $\begin{array}{l}\text { Total } \\
\text { Hujan } \\
\text { Efetif }\end{array}$ \\
\hline $1 / 3 / 2017 \quad 1: 45$ & 5,203 & 0 & 4,116 & 1,087 & & & & & & & \\
\hline $1 / 3 / 2017 \quad 2: 00$ & 5,134 & 0 & 4,124 & 1,009 & & & & & & & \\
\hline $1 / 3 / 2017 \quad 2: 15$ & 5,056 & 0 & 4,133 & 0,924 & & & & & & & \\
\hline $1 / 3 / 2017 \quad 2: 30$ & 4,998 & 0 & 4,141 & 0,857 & & & & & & & \\
\hline $1 / 3 / 2017 \quad 2: 45$ & 4,949 & 0 & 4,150 & 0,799 & & & & & & & \\
\hline $1 / 3 / 2017 \quad 3: 00$ & 4,896 & 0 & 4,158 & 0,737 & & & & & & & \\
\hline $1 / 3 / 2017 \quad 3: 15$ & 4,852 & 0 & 4,167 & 0,685 & & & & & & & \\
\hline $1 / 3 / 2017 \quad 3: 30$ & 4,830 & 0 & 4,175 & 0,655 & & & & & & & \\
\hline $1 / 3 / 2017 \quad 3: 45$ & 4,808 & 0 & 4,184 & 0,624 & & & & & & & \\
\hline $1 / 3 / 2017 \quad 4: 00$ & 4,765 & 0 & 4,192 & 0,573 & & & & & & & \\
\hline $1 / 3 / 2017 \quad 4: 15$ & 4,730 & 0 & 4,201 & 0,530 & & & & & & & \\
\hline $1 / 3 / 2017 \quad 4: 30$ & 4,692 & 0 & 4,209 & 0,483 & & & & & & & \\
\hline $1 / 3 / 2017 \quad 4: 45$ & 4,645 & 0 & 4,218 & 0,427 & & & & & & & \\
\hline $1 / 3 / 2017 \quad 5: 00$ & 4,598 & 0 & 4,226 & 0,372 & & & & & & & \\
\hline $1 / 3 / 2017 \quad 5: 15$ & 4,557 & 0 & 4,235 & 0,322 & & & & & & & \\
\hline $1 / 3 / 2017 \quad 5: 30$ & 4,519 & 0 & 4,243 & 0,276 & & & & & & & \\
\hline $1 / 3 / 2017 \quad 5: 45$ & 4,494 & 0 & 4,251 & 0,243 & & & & & & & \\
\hline $1 / 3 / 2017 \quad 6: 00$ & 4,461 & 0 & 4,260 & 0,201 & & & & & & & \\
\hline $1 / 3 / 2017 \quad 6: 15$ & 4,429 & 0 & 4,268 & 0,160 & & & & & & & \\
\hline $1 / 3 / 2017 \quad 6: 30$ & 4,400 & 0 & 4,277 & 0,123 & & & & & & & \\
\hline $1 / 3 / 2017 \quad 6: 45$ & 4,372 & 0 & 4,285 & 0,086 & & & & & & & \\
\hline 1/3/2017 7:00 & 4,372 & 0 & 4,294 & 0,078 & & & & & & & \\
\hline $1 / 3 / 2017 \quad 7: 15$ & 4,356 & 0 & 4,302 & 0,053 & & & & & & & \\
\hline $1 / 3 / 2017 \quad 7: 30$ & 4,335 & 0 & 4,311 & 0,025 & & & & & & & \\
\hline
\end{tabular}




\section{Lampiran 3. Perhitungan Hujan Efektif Gua Pindul}

Waktu awal hujan 1 Maret 2017 14:15

\begin{tabular}{|c|c|c|c|c|c|c|c|c|c|c|c|}
\hline Waktu & $Q(\mathbf{m} 3 / \mathbf{s})$ & $\begin{array}{c}\mathbf{P} \\
(\mathbf{m m})\end{array}$ & $\begin{array}{c}\text { Baseflow } \\
(\mathrm{m} 3 / \mathrm{s})\end{array}$ & $\begin{array}{c}\text { DRO } \\
(\mathrm{m} 3 / \mathrm{s})\end{array}$ & $\begin{array}{c}\text { Total } \\
\text { DRO } \\
(\mathrm{m} 3 / \mathrm{s})\end{array}$ & $\begin{array}{c}\text { Volume } \\
\text { DRO } \\
\text { (m3) }\end{array}$ & $\begin{array}{l}\text { Luas } \\
\text { DTA } \\
(\mathbf{m} 2)\end{array}$ & $\begin{array}{l}\text { Tebal } \\
\text { DRO } \\
(\mathrm{mm})\end{array}$ & $\begin{array}{c}\phi(\mathrm{mm} / \\
15 \\
\text { menit })\end{array}$ & $\begin{array}{c}\text { Hujan } \\
\text { efektif } \\
(\mathbf{m m})\end{array}$ & $\begin{array}{l}\text { Total } \\
\text { Hujan } \\
\text { Efetif }\end{array}$ \\
\hline 3/1/2017 13:30 & 4,088 & 0 & 4,088 & 0,00 & 313 & 281368 & 15440000 & 18,22 & 2,44 & & 18,22 \\
\hline $3 / 1 / 2017 \quad 13: 45$ & 4,080 & 0 & 4,080 & 0,00 & & & & & & & \\
\hline 3/1/2017 14:00 & 4,069 & 0 & 4,069 & 0,00 & & & & & & & \\
\hline $3 / 1 / 2017 \quad 14: 15$ & 4,046 & 0,4 & 4,046 & 0,00 & & & & & & & \\
\hline $3 / 1 / 2017 \quad 14: 30$ & 4,042 & 3,4 & 4,042 & 0,00 & & & & & & 0,96 & \\
\hline $3 / 1 / 2017 \quad 14: 45$ & 4,119 & 11,6 & 4,060 & 0,06 & & & & & & 9,16 & \\
\hline $3 / 1 / 2017 \quad 15: 00$ & 4,437 & 10,4 & 4,077 & 0,36 & & & & & & 7,96 & \\
\hline $3 / 1 / 2017 \quad 15: 15$ & 5,161 & 2,6 & 4,095 & 1,07 & & & & & & 0,16 & \\
\hline $3 / 1 / 2017 \quad 15: 30$ & 10,620 & 1,4 & 4,112 & 6,51 & & & & & & & \\
\hline $3 / 1 / 2017 \quad 15: 45$ & 20,807 & 0,2 & 4,130 & 16,68 & & & & & & & \\
\hline $3 / 1 / 2017 \quad 16: 00$ & 27,466 & 0 & 4,148 & 23,32 & & & & & & & \\
\hline $3 / 1 / 2017 \quad 16: 15$ & 30,681 & 0 & 4,165 & 26,52 & & & & & & & \\
\hline $3 / 1 / 2017 \quad 16: 30$ & 29,597 & 0 & 4,183 & 25,41 & & & & & & & \\
\hline $3 / 1 / 2017 \quad 16: 45$ & 27,649 & 0 & 4,200 & 23,45 & & & & & & & \\
\hline 3/1/2017 17:00 & 25,643 & 0 & 4,218 & 21,43 & & & & & & & \\
\hline $3 / 1 / 2017 \quad 17: 15$ & 23,633 & 0 & 4,236 & 19,40 & & & & & & & \\
\hline $3 / 1 / 2017 \quad 17: 30$ & 21,691 & 0 & 4,253 & 17,44 & & & & & & & \\
\hline $3 / 1 / 2017 \quad 17: 45$ & 19,732 & 0 & 4,271 & 15,46 & & & & & & & \\
\hline $3 / 1 / 2017 \quad 18: 00$ & 17,498 & 0 & 4,288 & 13,21 & & & & & & & \\
\hline $3 / 1 / 2017 \quad 18: 15$ & 15,612 & 0 & 4,306 & 11,31 & & & & & & & \\
\hline $3 / 1 / 2017 \quad 18: 30$ & 14,094 & 0 & 4,324 & 9,77 & & & & & & & \\
\hline $3 / 1 / 2017 \quad 18: 45$ & 12,812 & 0 & 4,341 & 8,47 & & & & & & & \\
\hline $3 / 1 / 2017 \quad 19: 00$ & 11,819 & 0 & 4,359 & 7,46 & & & & & & & \\
\hline $3 / 1 / 2017 \quad 19: 15$ & 10,902 & 0 & 4,377 & 6,53 & & & & & & & \\
\hline
\end{tabular}




\begin{tabular}{|c|c|c|c|c|c|c|c|c|c|c|c|}
\hline Waktu & $\mathrm{Q}(\mathrm{m} 3 / \mathrm{s})$ & $\underset{(\mathbf{m m})}{\mathbf{P}}$ & $\begin{array}{c}\text { Baseflow } \\
(\mathrm{m} 3 / \mathrm{s})\end{array}$ & $\begin{array}{c}\text { DRO } \\
(\mathrm{m} 3 / \mathrm{s})\end{array}$ & $\begin{array}{c}\text { Total } \\
\text { DRO } \\
(\mathrm{m} 3 / \mathrm{s}) \\
\end{array}$ & $\begin{array}{c}\text { Volume } \\
\text { DRO } \\
\text { (m3) }\end{array}$ & $\begin{array}{l}\text { Luas } \\
\text { DTA } \\
(\mathrm{m} 2) \\
\end{array}$ & $\begin{array}{l}\text { Tebal } \\
\text { DRO } \\
(\mathrm{mm}) \\
\end{array}$ & $\begin{array}{c}\phi(\mathrm{mm} / \\
15 \\
\text { menit })\end{array}$ & $\begin{array}{c}\text { Hujan } \\
\text { efektif } \\
(\mathrm{mm})\end{array}$ & $\begin{array}{c}\text { Total } \\
\text { Hujan } \\
\text { Efetif }\end{array}$ \\
\hline $3 / 1 / 2017 \quad 19: 30$ & 10,156 & 0 & 4,394 & 5,76 & & & & & & & \\
\hline $3 / 1 / 2017 \quad 19: 45$ & 9,502 & 0 & 4,412 & 5,09 & & & & & & & \\
\hline $3 / 1 / 2017 \quad 20: 00$ & 8,957 & 0 & 4,429 & 4,53 & & & & & & & \\
\hline $3 / 1 / 2017 \quad 20: 15$ & 8,490 & 0 & 4,447 & 4,04 & & & & & & & \\
\hline $3 / 1 / 2017 \quad 20: 30$ & 8,106 & 0,8 & 4,465 & 3,64 & & & & & & & \\
\hline $3 / 1 / 2017 \quad 20: 45$ & 7,818 & 0,4 & 4,482 & 3,34 & & & & & & & \\
\hline 3/1/2017 21:00 & 7,544 & 1,2 & 4,500 & 3,04 & & & & & & & \\
\hline $3 / 1 / 2017 \quad 21: 15$ & 7,337 & 1,2 & 4,517 & 2,82 & & & & & & & \\
\hline $3 / 1 / 2017 \quad 21: 30$ & 7,076 & 0,6 & 4,535 & 2,54 & & & & & & & \\
\hline $3 / 1 / 2017 \quad 21: 45$ & 6,885 & 0,4 & 4,553 & 2,33 & & & & & & & \\
\hline $3 / 1 / 2017 \quad 22: 00$ & 6,771 & 0,2 & 4,570 & 2,20 & & & & & & & \\
\hline $3 / 1 / 2017 \quad 22: 15$ & 6,698 & 0 & 4,588 & 2,11 & & & & & & & \\
\hline $3 / 1 / 2017 \quad 22: 30$ & 6,598 & 0 & 4,605 & 1,99 & & & & & & & \\
\hline $3 / 1 / 2017 \quad 22: 45$ & 6,488 & 0,2 & 4,623 & 1,86 & & & & & & & \\
\hline $3 / 1 / 2017 \quad 23: 00$ & 6,379 & 0 & 4,641 & 1,74 & & & & & & & \\
\hline $3 / 1 / 2017 \quad 23: 15$ & 6,250 & 0 & 4,658 & 1,59 & & & & & & & \\
\hline $3 / 1 / 2017 \quad 23: 30$ & 6,139 & 0 & 4,676 & 1,46 & & & & & & & \\
\hline $3 / 1 / 2017 \quad 23: 45$ & 6,014 & 0 & 4,693 & 1,32 & & & & & & & \\
\hline $3 / 2 / 2017 \quad 0: 00$ & 5,896 & 0 & 4,711 & 1,19 & & & & & & & \\
\hline $3 / 2 / 2017 \quad 0: 15$ & 5,785 & 0 & 4,729 & 1,06 & & & & & & & \\
\hline $3 / 2 / 2017 \quad 0: 30$ & 5,686 & 0 & 4,746 & 0,94 & & & & & & & \\
\hline $3 / 2 / 2017 \quad 0: 45$ & 5,607 & 0 & 4,764 & 0,84 & & & & & & & \\
\hline $3 / 2 / 2017 \quad 1: 00$ & 5,495 & 0 & 4,781 & 0,71 & & & & & & & \\
\hline $3 / 2 / 2017 \quad 1: 15$ & 5,433 & 0 & 4,799 & 0,63 & & & & & & & \\
\hline $3 / 2 / 2017 \quad 1: 30$ & 5,352 & 0 & 4,817 & 0,54 & & & & & & & \\
\hline $3 / 2 / 2017 \quad 1: 45$ & 5,277 & 0 & 4,834 & 0,44 & & & & & & & \\
\hline
\end{tabular}




\begin{tabular}{|c|c|c|c|c|c|c|c|c|c|c|c|}
\hline Waktu & $Q(\mathbf{m} 3 / \mathbf{s})$ & $\underset{(\mathbf{m m})}{\mathbf{P}}$ & $\begin{array}{c}\text { Baseflow } \\
(\mathbf{m 3} / \mathbf{s})\end{array}$ & $\begin{array}{c}\text { DRO } \\
(\mathrm{m} 3 / \mathbf{s})\end{array}$ & $\begin{array}{c}\text { Total } \\
\text { DRO } \\
(\mathrm{m} 3 / \mathrm{s})\end{array}$ & $\begin{array}{c}\text { Volume } \\
\text { DRO } \\
\text { (m3) }\end{array}$ & $\begin{array}{l}\text { Luas } \\
\text { DTA } \\
\text { (m2) }\end{array}$ & $\begin{array}{l}\text { Tebal } \\
\text { DRO } \\
(\mathbf{m m})\end{array}$ & $\begin{array}{c}\phi(\mathrm{mm} / \\
15 \\
\text { menit) }\end{array}$ & $\begin{array}{c}\text { Hujan } \\
\text { efektif } \\
(\mathbf{m m})\end{array}$ & $\begin{array}{l}\text { Total } \\
\text { Hujan } \\
\text { Efetif }\end{array}$ \\
\hline $3 / 2 / 2017 \quad 2: 00$ & 5,216 & 0 & 4,852 & 0,36 & & & & & & & \\
\hline 3/2/2017 2:15 & 5,143 & 0 & 4,869 & 0,27 & & & & & & & \\
\hline $3 / 2 / 2017 \quad 2: 30$ & 5,093 & 0 & 4,887 & 0,21 & & & & & & & \\
\hline $3 / 2 / 2017 \quad 2: 45$ & 5,038 & 0 & 4,905 & 0,13 & & & & & & & \\
\hline 3/2/2017 3:00 & 4,975 & 0 & 4,922 & 0,05 & & & & & & & \\
\hline
\end{tabular}




\section{Lampiran 3. Perhitungan Hujan Efektif Gua Pindul}

Waktu awal hujan 5 Maret 2017 14:00

\begin{tabular}{|c|c|c|c|c|c|c|c|c|c|c|c|}
\hline Waktu & $Q(\mathrm{~m} 3 / \mathrm{s})$ & $\mathbf{P}(\mathbf{m m})$ & $\begin{array}{c}\text { Baseflow } \\
(\mathrm{m} 3 / \mathrm{s})\end{array}$ & $\begin{array}{c}\text { DRO } \\
(\mathrm{m} 3 / \mathrm{s})\end{array}$ & $\begin{array}{c}\text { Total } \\
\text { DRO } \\
(\mathrm{m} 3 / \mathbf{s})\end{array}$ & $\begin{array}{c}\text { Volume } \\
\text { DRO } \\
\text { (m3) }\end{array}$ & $\begin{array}{l}\text { Luas DTA } \\
\quad \text { (m2) }\end{array}$ & $\begin{array}{l}\text { Tebal } \\
\text { DRO } \\
(\mathrm{mm})\end{array}$ & $\begin{array}{c}\phi(\mathrm{mm} / \\
15 \\
\text { menit })\end{array}$ & $\begin{array}{c}\text { Hujan } \\
\text { efektif } \\
(\mathrm{mm})\end{array}$ & $\begin{array}{l}\text { Total } \\
\text { Hujan } \\
\text { Efetif }\end{array}$ \\
\hline $5 / 3 / 2017 \quad 13: 15$ & 3,746 & 0 & 3,746 & 0,00 & 138 & 124.054 & 15.440 .000 & 8,03 & 6,17 & & 8,03 \\
\hline $5 / 3 / 2017 \quad 13: 30$ & 3,753 & 0 & 3,753 & 0,00 & & & & & & & \\
\hline $5 / 3 / 2017 \quad 13: 45$ & 3,753 & 0 & 3,753 & 0,00 & & & & & & & \\
\hline 5/3/2017 14:00 & 3,779 & 2 & 3,779 & 0,00 & & & & & & & \\
\hline $5 / 3 / 2017 \quad 14: 15$ & 3,866 & 14,2 & 3,789 & 0,08 & & & & & & 8,03 & \\
\hline $5 / 3 / 2017 \quad 14: 30$ & 4,177 & 5,2 & 3,799 & 0,38 & & & & & & & \\
\hline $5 / 3 / 2017 \quad 14: 45$ & 4,603 & 0,2 & 3,810 & 0,79 & & & & & & & \\
\hline 5/3/2017 15:00 & 6,250 & 0 & 3,820 & 2,43 & & & & & & & \\
\hline $5 / 3 / 2017 \quad 15: 15$ & 12,537 & 0 & 3,831 & 8,71 & & & & & & & \\
\hline $5 / 3 / 2017 \quad 15: 30$ & 15,378 & 0 & 3,841 & 11,54 & & & & & & & \\
\hline $5 / 3 / 2017 \quad 15: 45$ & 15,666 & 0 & 3,852 & 11,81 & & & & & & & \\
\hline 5/3/2017 16:00 & 14,989 & 0 & 3,862 & 11,13 & & & & & & & \\
\hline $5 / 3 / 2017 \quad 16: 15$ & 13,986 & 0 & 3,873 & 10,11 & & & & & & & \\
\hline $5 / 3 / 2017 \quad 16: 30$ & 13,081 & 0 & 3,883 & 9,20 & & & & & & & \\
\hline $5 / 3 / 2017 \quad 16: 45$ & 11,923 & 0 & 3,893 & 8,03 & & & & & & & \\
\hline 5/3/2017 17:00 & 10,756 & 0 & 3,904 & 6,85 & & & & & & & \\
\hline $5 / 3 / 2017 \quad 17: 15$ & 9,769 & 0 & 3,914 & 5,85 & & & & & & & \\
\hline 5/3/2017 17:30 & 9,041 & 0 & 3,925 & 5,12 & & & & & & & \\
\hline $5 / 3 / 2017 \quad 17: 45$ & 8,396 & 0 & 3,935 & 4,46 & & & & & & & \\
\hline 5/3/2017 18:00 & 7,894 & 0 & 3,946 & 3,95 & & & & & & & \\
\hline $5 / 3 / 2017 \quad 18: 15$ & 7,458 & 0 & 3,956 & 3,50 & & & & & & & \\
\hline $5 / 3 / 2017 \quad 18: 30$ & 7,111 & 0 & 3,967 & 3,14 & & & & & & & \\
\hline 5/3/2017 18:45 & 6,788 & 0 & 3,977 & 2,81 & & & & & & & \\
\hline
\end{tabular}




\begin{tabular}{|c|c|c|c|c|c|c|c|c|c|c|c|}
\hline Waktu & $Q(\mathbf{m} 3 / \mathbf{s})$ & $\mathbf{P}(\mathbf{m m})$ & $\begin{array}{c}\text { Bas eflow } \\
(\mathrm{m} 3 / \mathrm{s})\end{array}$ & $\begin{array}{c}\text { DRO } \\
(\mathrm{m} 3 / \mathrm{s})\end{array}$ & $\begin{array}{c}\text { Total } \\
\text { DRO } \\
(\mathrm{m} 3 / \mathbf{s}) \\
\end{array}$ & $\begin{array}{c}\text { Volume } \\
\text { DRO } \\
(\mathrm{m3}) \\
\end{array}$ & $\begin{array}{l}\text { Luas DTA } \\
\quad(\mathrm{m} 2)\end{array}$ & $\begin{array}{l}\text { Tebal } \\
\text { DRO } \\
(\mathrm{mm}) \\
\end{array}$ & $\begin{array}{c}\phi(\mathrm{mm} / \\
15 \\
\text { menit })\end{array}$ & $\begin{array}{c}\text { Hujan } \\
\text { efektif } \\
(\mathbf{m m})\end{array}$ & $\begin{array}{c}\text { Total } \\
\text { Hujan } \\
\text { Efetif } \\
\end{array}$ \\
\hline 5/3/2017 19:00 & 6,542 & 0 & 3,987 & 2,55 & & & & & & & \\
\hline $5 / 3 / 2017 \quad 19: 15$ & 6,314 & 0 & 3,998 & 2,32 & & & & & & & \\
\hline $5 / 3 / 2017 \quad 19: 30$ & 6,108 & 0 & 4,008 & 2,10 & & & & & & & \\
\hline $5 / 3 / 2017 \quad 19: 45$ & 5,942 & 0 & 4,019 & 1,92 & & & & & & & \\
\hline 5/3/2017 20:00 & 5,795 & 0 & 4,029 & 1,77 & & & & & & & \\
\hline $5 / 3 / 2017 \quad 20: 15$ & 5,661 & 0 & 4,040 & 1,62 & & & & & & & \\
\hline $5 / 3 / 2017 \quad 20: 30$ & 5,548 & 0 & 4,050 & 1,50 & & & & & & & \\
\hline $5 / 3 / 2017 \quad 20: 45$ & 5,442 & 0 & 4,061 & 1,38 & & & & & & & \\
\hline 5/3/2017 21:00 & 5,338 & 0 & 4,071 & 1,27 & & & & & & & \\
\hline $5 / 3 / 2017 \quad 21: 15$ & 5,240 & 0 & 4,082 & 1,16 & & & & & & & \\
\hline $5 / 3 / 2017 \quad 21: 30$ & 5,152 & 0 & 4,092 & 1,06 & & & & & & & \\
\hline $5 / 3 / 2017 \quad 21: 45$ & 5,074 & 0 & 4,102 & 0,97 & & & & & & & \\
\hline $5 / 3 / 2017 \quad 22: 00$ & 5,020 & 0 & 4,113 & 0,91 & & & & & & & \\
\hline $5 / 3 / 2017 \quad 22: 15$ & 4,958 & 0 & 4,123 & 0,83 & & & & & & & \\
\hline $5 / 3 / 2017 \quad 22: 30$ & 4,891 & 0 & 4,134 & 0,76 & & & & & & & \\
\hline $5 / 3 / 2017 \quad 22: 45$ & 4,856 & 0 & 4,144 & 0,71 & & & & & & & \\
\hline $5 / 3 / 2017 \quad 23: 00$ & 4,834 & 0 & 4,155 & 0,68 & & & & & & & \\
\hline $5 / 3 / 2017 \quad 23: 15$ & 4,799 & 0 & 4,165 & 0,63 & & & & & & & \\
\hline $5 / 3 / 2017 \quad 23: 30$ & 4,765 & 0 & 4,176 & 0,59 & & & & & & & \\
\hline $5 / 3 / 2017 \quad 23: 45$ & 4,730 & 0 & 4,186 & 0,54 & & & & & & & \\
\hline 6/3/2017 0:00 & 4,692 & 0 & 4,196 & 0,50 & & & & & & & \\
\hline $6 / 3 / 2017 \quad 0: 15$ & 4,649 & 0 & 4,207 & 0,44 & & & & & & & \\
\hline $6 / 3 / 2017 \quad 0: 30$ & 4,598 & 0 & 4,217 & 0,38 & & & & & & & \\
\hline 6/3/2017 $0: 45$ & 4,557 & 0 & 4,228 & 0,33 & & & & & & & \\
\hline $6 / 3 / 2017 \quad 1: 00$ & 4,519 & 0 & 4,238 & 0,28 & & & & & & & \\
\hline $6 / 3 / 2017 \quad 1: 15$ & 4,486 & 0 & 4,249 & 0,24 & & & & & & & \\
\hline
\end{tabular}




\begin{tabular}{|c|c|c|c|c|c|c|c|c|c|c|c|}
\hline Waktu & $\mathrm{Q}(\mathrm{m} 3 / \mathbf{s})$ & $\mathbf{P}(\mathbf{m m})$ & $\begin{array}{c}\text { Baseflow } \\
(\mathrm{m} 3 / \mathbf{s})\end{array}$ & $\begin{array}{c}\text { DRO } \\
(\mathbf{m} 3 / \mathbf{s})\end{array}$ & $\begin{array}{c}\text { Total } \\
\text { DRO } \\
(\mathrm{m} 3 / \mathbf{s})\end{array}$ & $\begin{array}{c}\text { Volume } \\
\text { DRO } \\
(\mathbf{m} 3) \\
\end{array}$ & $\begin{array}{l}\text { Luas DTA } \\
\quad(\mathrm{m} 2)\end{array}$ & $\begin{array}{l}\text { Tebal } \\
\text { DRO } \\
(\mathbf{m m})\end{array}$ & $\begin{array}{c}\phi(\mathrm{mm} / \\
15 \\
\text { menit })\end{array}$ & $\begin{array}{l}\text { Hujan } \\
\text { efek tif } \\
(\mathbf{m m})\end{array}$ & $\begin{array}{c}\text { Total } \\
\text { Hujan } \\
\text { Efetif }\end{array}$ \\
\hline $6 / 3 / 2017 \quad 1: 30$ & 4,449 & 0 & 4,259 & 0,19 & & & & & & & \\
\hline $\begin{array}{lll}6 / 3 / 2017 & 1: 45\end{array}$ & 4,396 & 0 & 4,270 & 0,13 & & & & & & & \\
\hline 6/3/2017 2:00 & 4,376 & 0 & 4,280 & 0,10 & & & & & & & \\
\hline 6/3/2017 2:15 & 4,356 & 0 & 4,290 & 0,07 & & & & & & & \\
\hline 6/3/2017 2:30 & 4,327 & 0 & 4,301 & 0,03 & & & & & & & \\
\hline
\end{tabular}




\section{Lampiran 3. Perhitungan Hujan Efektif Gua Pindul}

Waktu awal hujan 16 Maret 2017 16:00

\begin{tabular}{|c|c|c|c|c|c|c|c|c|c|c|c|}
\hline Waktu & $\mathbf{Q}(\mathbf{m} 3 / \mathbf{s})$ & $\mathbf{P}(\mathbf{m m})$ & $\begin{array}{c}\text { Bas eflow } \\
(\mathrm{m} 3 / \mathrm{s})\end{array}$ & $\begin{array}{c}\text { DRO } \\
(\mathrm{m} 3 / \mathrm{s})\end{array}$ & $\begin{array}{c}\text { Total } \\
\text { DRO } \\
(\mathrm{m} 3 / \mathrm{s})\end{array}$ & $\begin{array}{c}\text { Volume } \\
\text { DRO } \\
\text { (m3) }\end{array}$ & $\begin{array}{l}\text { Luas DTA } \\
\quad(\mathrm{m} 2)\end{array}$ & $\begin{array}{l}\text { Tebal } \\
\text { DRO } \\
(\mathrm{mm})\end{array}$ & $\begin{array}{c}\phi(\mathrm{mm} / \\
15 \\
\text { menit })\end{array}$ & $\begin{array}{c}\text { Hujan } \\
\text { efektif } \\
\text { (mm) }\end{array}$ & $\begin{array}{l}\text { Total } \\
\text { Hujan } \\
\text { Efetif }\end{array}$ \\
\hline 16/3/2017 16:00 & 3,654 & 0 & 3,654 & 0,000 & 95 & 85.674 & 15.440 .000 & 5,55 & 4,95 & & 5,55 \\
\hline 16/3/2017 16:15 & 3,661 & 0 & 3,661 & 0,000 & & & & & & & \\
\hline $16 / 3 / 2017 \quad 16: 30$ & 3,668 & 0 & 3,668 & 0,000 & & & & & & & \\
\hline 16/3/2017 16:45 & 3,689 & 0 & 3,689 & 0,000 & & & & & & & \\
\hline 16/3/2017 17:00 & 3,696 & 0 & 3,696 & 0,000 & & & & & & & \\
\hline 16/3/2017 17:15 & 3,714 & 6,4 & 3,714 & 0,000 & & & & & & 1,45 & \\
\hline 16/3/2017 $17: 30$ & 3,768 & 8,2 & 3,723 & 0,045 & & & & & & 3,25 & \\
\hline 16/3/2017 17:45 & 3,885 & 5,8 & 3,731 & 0,153 & & & & & & 0,85 & \\
\hline 16/3/2017 18:00 & 4,004 & 2,6 & 3,740 & 0,264 & & & & & & & \\
\hline 16/3/2017 18:15 & 4,649 & 0,2 & 3,749 & 0,900 & & & & & & & \\
\hline 16/3/2017 18:30 & 5,471 & 0 & 3,758 & 1,713 & & & & & & & \\
\hline 16/3/2017 18:45 & 8,680 & 0 & 3,766 & 4,913 & & & & & & & \\
\hline 16/3/2017 19:00 & 10,732 & 0 & 3,775 & 6,957 & & & & & & & \\
\hline 16/3/2017 19:15 & 10,886 & 0 & 3,784 & 7,102 & & & & & & & \\
\hline 16/3/2017 19:30 & 10,461 & 0 & 3,793 & 6,668 & & & & & & & \\
\hline 16/3/2017 19:45 & 10,026 & 0 & 3,801 & 6,224 & & & & & & & \\
\hline 16/3/2017 20:00 & 9,502 & 0,2 & 3,810 & 5,691 & & & & & & & \\
\hline 16/3/2017 20:15 & 8,999 & 0 & 3,819 & 5,180 & & & & & & & \\
\hline 16/3/2017 20:30 & 8,456 & 0 & 3,828 & 4,628 & & & & & & & \\
\hline $16 / 3 / 2017 \quad 20: 45$ & 7,926 & 0 & 3,837 & 4,089 & & & & & & & \\
\hline 16/3/2017 21:00 & 7,489 & 0 & 3,845 & 3,644 & & & & & & & \\
\hline
\end{tabular}




\begin{tabular}{|c|c|c|c|c|c|c|c|c|c|c|c|}
\hline Waktu & $Q(\mathbf{m} 3 / \mathbf{s})$ & $\mathbf{P}(\mathbf{m m})$ & $\begin{array}{c}\text { Bas eflow } \\
(\mathrm{m} 3 / \mathrm{s})\end{array}$ & $\begin{array}{c}\text { DRO } \\
(\mathrm{m} 3 / \mathrm{s})\end{array}$ & $\begin{array}{l}\text { Total } \\
\text { DRO } \\
(\mathrm{m} 3 / \mathrm{s}) \\
\end{array}$ & $\begin{array}{c}\text { Volume } \\
\text { DRO } \\
(\mathrm{m3})\end{array}$ & $\begin{array}{l}\text { Luas DTA } \\
\quad(\mathbf{m} 2)\end{array}$ & $\begin{array}{l}\text { Tebal } \\
\text { DRO } \\
(\mathrm{mm})\end{array}$ & $\begin{array}{c}\phi(\mathrm{mm} / \\
15 \\
\text { menit })\end{array}$ & $\begin{array}{c}\text { Hujan } \\
\text { efektif } \\
(\mathrm{mm})\end{array}$ & $\begin{array}{c}\text { Total } \\
\text { Hujan } \\
\text { Efetif }\end{array}$ \\
\hline $16 / 3 / 2017 \quad 21: 15$ & 7,111 & 0,2 & 3,854 & 3,257 & & & & & & & \\
\hline 16/3/2017 21:30 & 6,766 & 0 & 3,863 & 2,903 & & & & & & & \\
\hline 16/3/2017 21:45 & 6,498 & 0,2 & 3,872 & 2,627 & & & & & & & \\
\hline 16/3/2017 22:00 & 6,239 & 0 & 3,880 & 2,359 & & & & & & & \\
\hline $16 / 3 / 2017 \quad 22: 15$ & 6,014 & 0,2 & 3,889 & 2,125 & & & & & & & \\
\hline 16/3/2017 22:30 & 5,861 & 0 & 3,898 & 1,963 & & & & & & & \\
\hline 16/3/2017 22:45 & 5,725 & 0 & 3,907 & 1,819 & & & & & & & \\
\hline 16/3/2017 23:00 & 5,592 & 0 & 3,915 & 1,677 & & & & & & & \\
\hline $16 / 3 / 2017 \quad 23: 15$ & 5,476 & 2 & 3,924 & 1,552 & & & & & & & \\
\hline 16/3/2017 23:30 & 5,362 & 0 & 3,933 & 1,429 & & & & & & & \\
\hline $16 / 3 / 2017 \quad 23: 45$ & 5,258 & 0,2 & 3,942 & 1,317 & & & & & & & \\
\hline 17/3/2017 0:00 & 5,180 & 0 & 3,950 & 1,229 & & & & & & & \\
\hline $17 / 3 / 2017 \quad 0: 15$ & 5,097 & 0 & 3,959 & 1,138 & & & & & & & \\
\hline $17 / 3 / 2017 \quad 0: 30$ & 5,034 & 0 & 3,968 & 1,066 & & & & & & & \\
\hline 17/3/2017 0:45 & 4,958 & 0 & 3,977 & 0,981 & & & & & & & \\
\hline $17 / 3 / 2017 \quad 1: 00$ & 4,900 & 0 & 3,985 & 0,915 & & & & & & & \\
\hline $17 / 3 / 2017 \quad 1: 15$ & 4,830 & 0 & 3,994 & 0,836 & & & & & & & \\
\hline $17 / 3 / 2017 \quad 1: 30$ & 4,786 & 0 & 4,003 & 0,783 & & & & & & & \\
\hline $17 / 3 / 2017 \quad 1: 45$ & 4,747 & 0 & 4,012 & 0,736 & & & & & & & \\
\hline $17 / 3 / 2017 \quad 2: 00$ & 4,696 & 0 & 4,020 & 0,675 & & & & & & & \\
\hline $17 / 3 / 2017 \quad 2: 15$ & 4,649 & 0 & 4,029 & 0,620 & & & & & & & \\
\hline $17 / 3 / 2017 \quad 2: 30$ & 4,615 & 0 & 4,038 & 0,577 & & & & & & & \\
\hline $17 / 3 / 2017 \quad 2: 45$ & 4,582 & 0 & 4,047 & 0,535 & & & & & & & \\
\hline $17 / 3 / 2017 \quad 3: 00$ & 4,552 & 0 & 4,055 & 0,497 & & & & & & & \\
\hline $17 / 3 / 2017 \quad 3: 15$ & 4,519 & 0,2 & 4,064 & 0,455 & & & & & & & \\
\hline $17 / 3 / 2017 \quad 3: 30$ & 4,486 & 0 & 4,073 & 0,413 & & & & & & & \\
\hline
\end{tabular}




\begin{tabular}{|c|c|c|c|c|c|c|c|c|c|c|c|}
\hline Waktu & $\mathbf{Q}(\mathbf{m} 3 / \mathbf{s})$ & $\mathbf{P}(\mathbf{m m})$ & $\begin{array}{c}\text { Baseflow } \\
(\mathbf{m} 3 / \mathbf{s})\end{array}$ & $\begin{array}{l}\text { DRO } \\
(\mathrm{m} 3 / \mathrm{s})\end{array}$ & $\begin{array}{c}\text { Total } \\
\text { DRO } \\
(\mathrm{m} 3 / \mathbf{s})\end{array}$ & $\begin{array}{c}\text { Volume } \\
\text { DRO } \\
(\mathbf{m} 3) \\
\end{array}$ & $\begin{array}{c}\text { Luas DTA } \\
\text { (m2) }\end{array}$ & $\begin{array}{l}\text { Tebal } \\
\text { DRO } \\
(\mathbf{m m})\end{array}$ & $\begin{array}{c}\phi(\mathrm{mm} / \\
15 \\
\text { menit })\end{array}$ & $\begin{array}{c}\text { Hujan } \\
\text { efektif } \\
(\mathbf{m m})\end{array}$ & $\begin{array}{l}\text { Total } \\
\text { Hujan } \\
\text { Efetif }\end{array}$ \\
\hline 17/3/2017 3:45 & 4,465 & 0 & 4,082 & 0,384 & & & & & & & \\
\hline 17/3/2017 4:00 & 4,433 & 0 & 4,091 & 0,342 & & & & & & & \\
\hline 17/3/2017 4:15 & 4,412 & 0 & 4,099 & 0,313 & & & & & & & \\
\hline 17/3/2017 4:30 & 4,384 & 0 & 4,108 & 0,276 & & & & & & & \\
\hline 17/3/2017 4:45 & 4,368 & 0 & 4,117 & 0,251 & & & & & & & \\
\hline 17/3/2017 5:00 & 4,347 & 0 & 4,126 & 0,222 & & & & & & & \\
\hline 17/3/2017 5:15 & 4,311 & 0 & 4,134 & 0,177 & & & & & & & \\
\hline 17/3/2017 5:30 & 4,291 & 0 & 4,143 & 0,148 & & & & & & & \\
\hline 17/3/2017 5:45 & 4,291 & 0 & 4,152 & 0,140 & & & & & & & \\
\hline 17/3/2017 6:00 & 4,275 & 0 & 4,161 & 0,115 & & & & & & & \\
\hline 17/3/2017 6:15 & 4,248 & 0 & 4,169 & 0,078 & & & & & & & \\
\hline 17/3/2017 6:30 & 4,236 & 0 & 4,178 & 0,058 & & & & & & & \\
\hline 17/3/2017 6:45 & 4,216 & 0 & 4,187 & 0,029 & & & & & & & \\
\hline 17/3/2017 7:00 & 4,200 & 0 & 4,196 & 0,005 & & & & & & & \\
\hline
\end{tabular}




\section{Lampiran 3. Perhitungan Hujan Efektif Gua Pindul}

Waktu awal hujan 26 April 2017 17:45

\begin{tabular}{|c|c|c|c|c|c|c|c|c|c|c|c|}
\hline Waktu & $Q(\mathrm{~m} 3 / \mathrm{s})$ & $\mathbf{P}(\mathbf{m m})$ & $\begin{array}{c}\text { Bas eflow } \\
(\mathrm{m} 3 / \mathrm{s})\end{array}$ & $\begin{array}{c}\text { DRO } \\
(\mathrm{m} 3 / \mathrm{s})\end{array}$ & $\begin{array}{c}\text { Total } \\
\text { DRO } \\
(\mathrm{m} 3 / \mathrm{s})\end{array}$ & $\begin{array}{c}\text { Volume } \\
\text { DRO } \\
\text { (m3) }\end{array}$ & $\begin{array}{l}\text { Luas DTA } \\
\quad(\mathbf{m} 2)\end{array}$ & $\begin{array}{l}\text { Tebal } \\
\text { DRO } \\
(\mathrm{mm})\end{array}$ & $\begin{array}{c}\phi(\mathrm{mm} / \\
15 \\
\text { menit })\end{array}$ & $\begin{array}{c}\text { Hujan } \\
\text { efektif } \\
(\mathbf{m m})\end{array}$ & $\begin{array}{l}\text { Total } \\
\text { Hujan } \\
\text { Efetif }\end{array}$ \\
\hline $26 / 4 / 2017 \quad 17: 30$ & 3,808 & 0 & 3,808 & 0,000 & 129 & 116.118 & 15.440 .000 & 7,52 & 6,59 & & 7,52 \\
\hline $26 / 4 / 2017 \quad 17: 45$ & 3,808 & 0,6 & 3,808 & 0,000 & & & & & & & \\
\hline $26 / 4 / 2017 \quad 18: 00$ & 3,804 & 0 & 3,804 & 0,000 & & & & & & & \\
\hline 26/4/2017 18:15 & 3,811 & 3,6 & 3,811 & 0,000 & & & & & & & \\
\hline $26 / 4 / 2017 \quad 18: 30$ & 3,808 & 1,5 & 3,808 & 0,000 & & & & & & & \\
\hline 26/4/2017 18:45 & 3,833 & 13,8 & 3,815 & 0,018 & & & & & & 7,21 & \\
\hline 26/4/2017 19:00 & 3,981 & 6,9 & 3,823 & 0,158 & & & & & & 0,31 & \\
\hline 26/4/2017 19:15 & 4,189 & 1,5 & 3,831 & 0,358 & & & & & & & \\
\hline $26 / 4 / 2017 \quad 19: 30$ & 4,307 & 1,2 & 3,839 & 0,469 & & & & & & & \\
\hline 26/4/2017 19:45 & 4,692 & 0,6 & 3,847 & 0,845 & & & & & & & \\
\hline 26/4/2017 20:00 & 5,983 & 0,3 & 3,854 & 2,129 & & & & & & & \\
\hline 26/4/2017 20:15 & 10,485 & 0,3 & 3,862 & 6,622 & & & & & & & \\
\hline $26 / 4 / 2017 \quad 20: 30$ & 12,028 & 0 & 3,870 & 8,158 & & & & & & & \\
\hline 26/4/2017 20:45 & 12,510 & 0 & 3,878 & 8,632 & & & & & & & \\
\hline $26 / 4 / 2017 \quad 21: 00$ & 12,647 & 0 & 3,886 & 8,761 & & & & & & & \\
\hline 26/4/2017 21:15 & 12,384 & 0 & 3,893 & 8,490 & & & & & & & \\
\hline $26 / 4 / 2017 \quad 21: 30$ & 11,836 & 0 & 3,901 & 7,935 & & & & & & & \\
\hline $26 / 4 / 2017 \quad 21: 45$ & 11,132 & 0 & 3,909 & 7,223 & & & & & & & \\
\hline 26/4/2017 22:00 & 10,453 & 0 & 3,917 & 6,536 & & & & & & & \\
\hline 26/4/2017 22:15 & 9,769 & 0 & 3,925 & 5,844 & & & & & & & \\
\hline $26 / 4 / 2017 \quad 22: 30$ & 9,183 & 0 & 3,932 & 5,251 & & & & & & & \\
\hline $26 / 4 / 2017 \quad 22: 45$ & 8,645 & 0 & 3,940 & 4,705 & & & & & & & \\
\hline 26/4/2017 23:00 & 8,113 & 0 & 3,948 & 4,165 & & & & & & & \\
\hline $26 / 4 / 2017 \quad 23: 15$ & 7,711 & 0 & 3,956 & 3,755 & & & & & & & \\
\hline
\end{tabular}




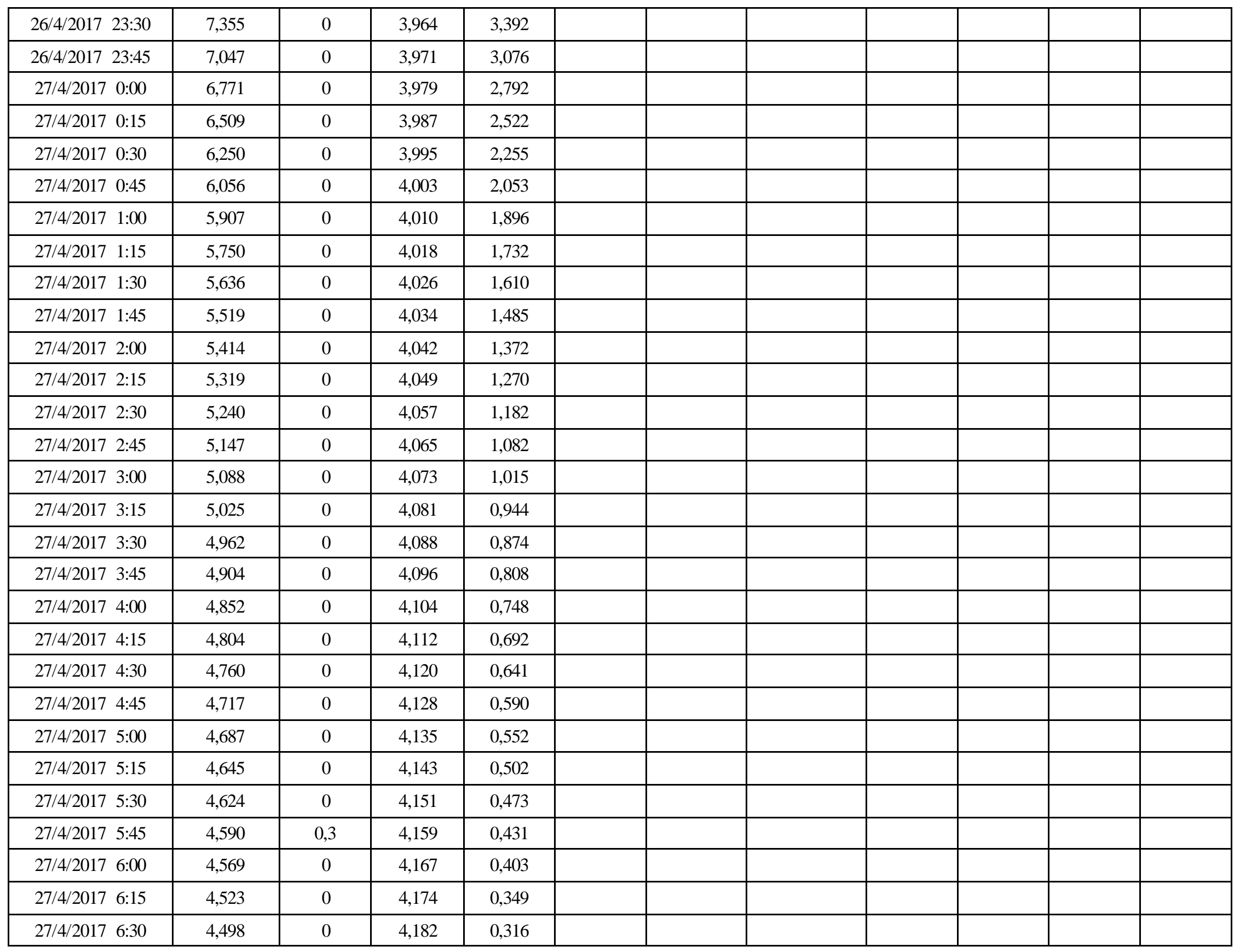




\begin{tabular}{|l|l|l|l|l|l|l|l|l|l|l|l|}
\hline $27 / 4 / 2017$ 6:45 & 4,486 & 0 & 4,190 & 0,296 & & & & & & & \\
\hline $27 / 4 / 2017$ 7:00 & 4,470 & 0 & 4,198 & 0,272 & & & & & & & \\
\hline $27 / 4 / 2017$ 7:15 & 4,441 & 0 & 4,206 & 0,235 & & & & & & & \\
\hline $27 / 4 / 20177: 30$ & 4,433 & 0 & 4,213 & 0,219 & & & & & & & \\
\hline $27 / 4 / 20177: 45$ & 4,408 & 0 & 4,221 & 0,187 & & & & & & & \\
\hline $27 / 4 / 20178: 00$ & 4,400 & 0 & 4,229 & 0,171 & & & & & & & \\
\hline $27 / 4 / 20178: 15$ & 4,396 & 0 & 4,237 & 0,159 & & & & & & & \\
\hline $27 / 4 / 20178: 30$ & 4,372 & 0 & 4,245 & 0,127 & & & & & & & \\
\hline $27 / 4 / 20178: 45$ & 4,343 & 0 & 4,252 & 0,091 & & & & & & & \\
\hline $27 / 4 / 20179: 00$ & 4,327 & 0 & 4,260 & 0,067 & & & & & & & \\
\hline $27 / 4 / 20179: 15$ & 4,315 & 0 & 4,268 & 0,047 & & & & & & & \\
\hline $27 / 4 / 20179: 30$ & 4,299 & 0 & 4,276 & 0,024 & & & & & & & \\
\hline $27 / 4 / 20179: 45$ & 4,295 & 0 & 4,284 & 0,012 & & & & & & & \\
\hline
\end{tabular}


Lampiran 4. Perhitungan hujan efektif Sinking Stream Kedungbuntung

Waktu awal hujan 5 Januari 2017 15:30

\begin{tabular}{|c|c|c|c|c|c|c|c|c|c|c|c|}
\hline Waktu & $\mathrm{Q}(\mathrm{m} 3 / \mathrm{s})$ & $\mathbf{P}$ & $\begin{array}{c}\text { Baseflow } \\
(\mathrm{m} 3 / \mathrm{s})\end{array}$ & $\begin{array}{l}\text { DRO } \\
(\mathrm{m} 3 / \mathrm{s})\end{array}$ & $\begin{array}{c}\text { Total } \\
\text { DRO } \\
(\mathrm{m} 3 / \mathbf{s}) \\
\end{array}$ & $\begin{array}{c}\text { Volume } \\
\text { DRO (m3) }\end{array}$ & $\begin{array}{l}\text { Luas DTA } \\
\quad(\mathrm{m} 2)\end{array}$ & $\begin{array}{l}\text { Tebal } \\
\text { DRO } \\
(\mathrm{mm})\end{array}$ & $\begin{array}{c}\phi(\mathrm{mm} / 15 \\
\text { menit })\end{array}$ & $\begin{array}{l}\text { Hujan } \\
\text { efektif } \\
(\mathbf{m m})\end{array}$ & $\begin{array}{c}\text { Total } \\
\text { Hujan } \\
\text { Efetif }\end{array}$ \\
\hline $5 / 1 / 2017 \quad 14: 45$ & 2,045 & 0 & 2,045 & 0,000 & 43,913 & 39.521 & 13.690 .000 & 2,89 & 7,31 & & 2,89 \\
\hline $5 / 1 / 2017 \quad 15: 00$ & 2,055 & 0 & 2,055 & 0,000 & & & & & & & \\
\hline $5 / 1 / 2017 \quad 15: 15$ & 2,047 & 0 & 2,047 & 0,000 & & & & & & & \\
\hline $5 / 1 / 2017 \quad 15: 30$ & 2,045 & 2,8 & 2,045 & 0,000 & & & & & & & \\
\hline $5 / 1 / 2017 \quad 15: 45$ & 2,111 & 10,2 & 2,053 & 0,059 & & & & & & 2,89 & \\
\hline 5/1/2017 16:00 & 2,185 & 6,6 & 2,060 & 0,125 & & & & & & & \\
\hline $5 / 1 / 2017 \quad 16: 15$ & 2,325 & 7 & 2,068 & 0,256 & & & & & & & \\
\hline $5 / 1 / 2017 \quad 16: 30$ & 2,499 & 3,6 & 2,076 & 0,423 & & & & & & & \\
\hline $5 / 1 / 2017 \quad 16: 45$ & 2,550 & 1 & 2,084 & 0,466 & & & & & & & \\
\hline 5/1/2017 17:00 & 3,164 & 0,2 & 2,091 & 1,073 & & & & & & & \\
\hline $5 / 1 / 2017 \quad 17: 15$ & 3,602 & 0,6 & 2,099 & 1,503 & & & & & & & \\
\hline $5 / 1 / 2017 \quad 17: 30$ & 3,673 & 0,4 & 2,107 & 1,567 & & & & & & & \\
\hline $5 / 1 / 2017 \quad 17: 45$ & 3,706 & 0,2 & 2,114 & 1,591 & & & & & & & \\
\hline 5/1/2017 18:00 & 4,589 & 0 & 2,122 & 2,467 & & & & & & & \\
\hline $5 / 1 / 2017 \quad 18: 15$ & 4,626 & 0 & 2,130 & 2,496 & & & & & & & \\
\hline 5/1/2017 18:30 & 4,462 & 0 & 2,138 & 2,324 & & & & & & & \\
\hline $5 / 1 / 2017 \quad 18: 45$ & 4,211 & 0 & 2,145 & 2,066 & & & & & & & \\
\hline 5/1/2017 19:00 & 3,928 & 0,2 & 2,153 & 1,775 & & & & & & & \\
\hline 5/1/2017 19:15 & 3,772 & 0 & 2,161 & 1,612 & & & & & & & \\
\hline $5 / 1 / 2017 \quad 19: 30$ & 3,641 & 0 & 2,169 & 1,473 & & & & & & & \\
\hline 5/1/2017 19:45 & 3,579 & 0 & 2,176 & 1,403 & & & & & & & \\
\hline 5/1/2017 20:00 & 3,487 & 0 & 2,184 & 1,303 & & & & & & & \\
\hline 5/1/2017 20:15 & 3,440 & 0 & 2,192 & 1,249 & & & & & & & \\
\hline $5 / 1 / 2017 \quad 20: 30$ & 3,398 & 0 & 2,200 & 1,199 & & & & & & & \\
\hline
\end{tabular}




\begin{tabular}{|c|c|c|c|c|c|c|c|c|c|c|c|}
\hline Waktu & $\mathrm{Q}(\mathrm{m} 3 / \mathrm{s})$ & $\mathbf{P}$ & $\begin{array}{c}\text { Baseflow } \\
(\mathrm{m} 3 / \mathbf{s})\end{array}$ & $\begin{array}{c}\text { DRO } \\
(\mathrm{m} 3 / \mathrm{s})\end{array}$ & $\begin{array}{c}\text { Total } \\
\text { DRO } \\
(\mathrm{m} 3 / \mathbf{s})\end{array}$ & $\begin{array}{c}\text { Volume } \\
\text { DRO (m3) }\end{array}$ & $\begin{array}{c}\text { Luas DTA } \\
\quad(\mathbf{m} 2)\end{array}$ & $\begin{array}{l}\text { Tebal } \\
\text { DRO } \\
(\mathrm{mm})\end{array}$ & $\begin{array}{c}\phi(\mathrm{mm} / 15 \\
\text { menit })\end{array}$ & $\begin{array}{c}\begin{array}{c}\text { Hujan } \\
\text { efektif } \\
(\mathrm{mm})\end{array} \\
\end{array}$ & $\begin{array}{c}\text { Total } \\
\text { Hujan } \\
\text { Efetif }\end{array}$ \\
\hline 5/1/2017 20:45 & 3,316 & 0 & 2,207 & 1,109 & & & & & & & \\
\hline 5/1/2017 21:00 & 3,264 & 0 & 2,215 & 1,049 & & & & & & & \\
\hline $5 / 1 / 2017 \quad 21: 15$ & 3,191 & 0 & 2,223 & 0,969 & & & & & & & \\
\hline 5/1/2017 21:30 & 3,132 & 0 & 2,230 & 0,901 & & & & & & & \\
\hline $5 / 1 / 2017 \quad 21: 45$ & 3,107 & 0 & 2,238 & 0,868 & & & & & & & \\
\hline $5 / 1 / 2017 \quad 22: 00$ & 3,047 & 0 & 2,246 & 0,801 & & & & & & & \\
\hline $5 / 1 / 2017 \quad 22: 15$ & 3,019 & 0 & 2,254 & 0,766 & & & & & & & \\
\hline $5 / 1 / 2017 \quad 22: 30$ & 2,964 & 0 & 2,261 & 0,703 & & & & & & & \\
\hline 5/1/2017 22:45 & 2,962 & 0 & 2,269 & 0,693 & & & & & & & \\
\hline $5 / 1 / 2017 \quad 23: 00$ & 2,919 & 0 & 2,277 & 0,642 & & & & & & & \\
\hline $5 / 1 / 2017 \quad 23: 15$ & 2,906 & 0 & 2,285 & 0,622 & & & & & & & \\
\hline $5 / 1 / 2017 \quad 23: 30$ & 2,876 & 0 & 2,292 & 0,584 & & & & & & & \\
\hline 5/1/2017 23:45 & 2,841 & 0 & 2,300 & 0,541 & & & & & & & \\
\hline $6 / 1 / 2017 \quad 0: 00$ & 2,824 & 0 & 2,308 & 0,516 & & & & & & & \\
\hline $6 / 1 / 2017 \quad 0: 15$ & 2,841 & 0 & 2,315 & 0,526 & & & & & & & \\
\hline $6 / 1 / 2017 \quad 0: 30$ & 2,811 & 0 & 2,323 & 0,488 & & & & & & & \\
\hline $6 / 1 / 2017 \quad 0: 45$ & 2,799 & 0 & 2,331 & 0,468 & & & & & & & \\
\hline $6 / 1 / 2017 \quad 1: 00$ & 2,763 & 0 & 2,339 & 0,425 & & & & & & & \\
\hline $6 / 1 / 2017 \quad 1: 15$ & 2,761 & 0 & 2,346 & 0,415 & & & & & & & \\
\hline $6 / 1 / 2017 \quad 1: 30$ & 2,743 & 0 & 2,354 & 0,389 & & & & & & & \\
\hline $6 / 1 / 2017 \quad 1: 45$ & 2,726 & 0 & 2,362 & 0,364 & & & & & & & \\
\hline $6 / 1 / 2017 \quad 2: 00$ & 2,696 & 0 & 2,370 & 0,326 & & & & & & & \\
\hline $6 / 1 / 2017 \quad 2: 15$ & 2,696 & 0 & 2,377 & 0,318 & & & & & & & \\
\hline $6 / 1 / 2017 \quad 2: 30$ & 2,698 & 0 & 2,385 & 0,313 & & & & & & & \\
\hline $6 / 1 / 2017 \quad 2: 45$ & 2,686 & 0 & 2,393 & 0,293 & & & & & & & \\
\hline $6 / 1 / 20173: 00$ & 2,660 & 0 & 2,400 & 0,260 & & & & & & & \\
\hline $6 / 1 / 2017 \quad 3: 15$ & 2,655 & 0 & 2,408 & 0,247 & & & & & & & \\
\hline
\end{tabular}




\begin{tabular}{|c|c|c|c|c|c|c|c|c|c|c|c|}
\hline Waktu & $\mathrm{Q}(\mathrm{m} 3 / \mathrm{s})$ & $\mathbf{P}$ & $\begin{array}{c}\text { Baseflow } \\
(\mathrm{m} 3 / \mathrm{s})\end{array}$ & $\begin{array}{c}\text { DRO } \\
(\mathrm{m} 3 / \mathrm{s})\end{array}$ & $\begin{array}{c}\text { Total } \\
\text { DRO } \\
(\mathrm{m} 3 / \mathbf{s})\end{array}$ & $\begin{array}{c}\text { Volume } \\
\text { DRO (m3) }\end{array}$ & $\begin{array}{l}\text { Luas DTA } \\
\quad(\mathbf{m} 2)\end{array}$ & $\begin{array}{l}\text { Tebal } \\
\text { DRO } \\
\text { (mm) }\end{array}$ & $\underset{\text { menit })}{\phi(\mathrm{mm} / 15}$ & $\begin{array}{c}\text { Hujan } \\
\text { efektif } \\
(\mathbf{m m})\end{array}$ & $\begin{array}{c}\text { Total } \\
\text { Hujan } \\
\text { Efetif }\end{array}$ \\
\hline 6/1/2017 3:30 & 2,653 & 0 & 2,416 & 0,237 & & & & & & & \\
\hline 6/1/2017 3:45 & 2,638 & 0 & 2,424 & 0,214 & & & & & & & \\
\hline 6/1/2017 4:00 & 2,635 & 0 & 2,431 & 0,204 & & & & & & & \\
\hline 6/1/2017 4:15 & 2,620 & 0 & 2,439 & 0,181 & & & & & & & \\
\hline 6/1/2017 4:30 & 2,618 & 0 & 2,447 & 0,171 & & & & & & & \\
\hline 6/1/2017 4:45 & 2,615 & 0 & 2,455 & 0,160 & & & & & & & \\
\hline 6/1/2017 5:00 & 2,595 & 0 & 2,462 & 0,133 & & & & & & & \\
\hline $6 / 1 / 2017 \quad 5: 15$ & 2,615 & 0 & 2,470 & 0,145 & & & & & & & \\
\hline $6 / 1 / 2017 \quad 5: 30$ & 2,590 & 0 & 2,478 & 0,112 & & & & & & & \\
\hline $6 / 1 / 2017 \quad 5: 45$ & 2,590 & 0 & 2,486 & 0,104 & & & & & & & \\
\hline 6/1/2017 6:00 & 2,567 & 0 & 2,493 & 0,074 & & & & & & & \\
\hline 6/1/2017 6:15 & 2,550 & 0 & 2,501 & 0,049 & & & & & & & \\
\hline 6/1/2017 6:30 & 2,555 & 0 & 2,509 & 0,046 & & & & & & & \\
\hline 6/1/2017 6:45 & 2,557 & 0 & 2,516 & 0,041 & & & & & & & \\
\hline 6/1/2017 7:00 & 2,545 & 0 & 2,524 & 0,020 & & & & & & & \\
\hline
\end{tabular}


Lampiran 4. Perhitungan Hujan Efektif Sinking Stream Kedungbuntung

Waktu awal hujan 8 Januari 2017 15:15

\begin{tabular}{|c|c|c|c|c|c|c|c|c|c|c|c|}
\hline Waktu & $\begin{array}{c}\mathrm{Q} \\
(\mathrm{m} 3 / \mathrm{s})\end{array}$ & $\begin{array}{c}\mathbf{P} \\
(\mathbf{m m})\end{array}$ & $\begin{array}{c}\text { Baseflow } \\
(\mathrm{m} 3 / \mathrm{s})\end{array}$ & $\begin{array}{l}\text { DRO } \\
(\mathrm{m} 3 / \mathrm{s})\end{array}$ & $\begin{array}{l}\text { Total } \\
\text { DRO } \\
(\mathrm{m} 3 / \mathrm{s})\end{array}$ & $\begin{array}{c}\text { Volume } \\
\text { DRO } \\
\text { (m3) }\end{array}$ & $\begin{array}{c}\text { Luas DTA } \\
\quad(\mathbf{m} 2)\end{array}$ & $\begin{array}{l}\text { Tebal } \\
\text { DRO } \\
(\mathrm{mm})\end{array}$ & $\begin{array}{c}\phi(\mathrm{mm} / \\
15 \\
\text { menit })\end{array}$ & $\begin{array}{c}\text { Hujan } \\
\text { efektif } \\
(\mathrm{mm})\end{array}$ & $\begin{array}{c}\text { Total } \\
\text { Hujan } \\
\text { Efetif }\end{array}$ \\
\hline $1 / 8 / 2017 \quad 14: 30$ & 2,007 & 0 & 2,007 & 0,000 & 11,995 & 10.796 & 13.690 .000 & 0,79 & 6,41 & & 0,79 \\
\hline $1 / 8 / 2017 \quad 14: 45$ & 2,007 & 0 & 2,007 & 0,000 & & & & & & & \\
\hline $1 / 8 / 2017 \quad 15: 00$ & 2,017 & 0 & 2,017 & 0,000 & & & & & & & \\
\hline $1 / 8 / 2017 \quad 15: 15$ & 2,035 & 4 & 2,035 & 0,000 & & & & & & & \\
\hline $1 / 8 / 2017 \quad 15: 30$ & 2,170 & 7,2 & 2,049 & 0,121 & & & & & & 0,79 & \\
\hline $1 / 8 / 2017 \quad 15: 45$ & 2,294 & 3,2 & 2,063 & 0,232 & & & & & & & \\
\hline 1/8/2017 16:00 & 2,312 & 0 & 2,076 & 0,235 & & & & & & & \\
\hline $1 / 8 / 2017 \quad 16: 15$ & 2,499 & 0 & 2,090 & 0,409 & & & & & & & \\
\hline $1 / 8 / 2017 \quad 16: 30$ & 2,527 & 0 & 2,104 & 0,423 & & & & & & & \\
\hline $1 / 8 / 2017 \quad 16: 45$ & 2,570 & 0 & 2,118 & 0,452 & & & & & & & \\
\hline $1 / 8 / 2017 \quad 17: 00$ & 2,592 & 0 & 2,132 & 0,460 & & & & & & & \\
\hline $1 / 8 / 2017 \quad 17: 15$ & 2,628 & 0 & 2,146 & 0,482 & & & & & & & \\
\hline $1 / 8 / 2017 \quad 17: 30$ & 2,836 & 0 & 2,160 & 0,676 & & & & & & & \\
\hline 1/8/2017 17:45 & 2,934 & 0 & 2,174 & 0,760 & & & & & & & \\
\hline 1/8/2017 18:00 & 2,881 & 0 & 2,188 & 0,694 & & & & & & & \\
\hline $1 / 8 / 2017 \quad 18: 15$ & 2,856 & 0 & 2,202 & 0,655 & & & & & & & \\
\hline $1 / 8 / 2017 \quad 18: 30$ & 2,816 & 0 & 2,216 & 0,601 & & & & & & & \\
\hline $1 / 8 / 2017 \quad 18: 45$ & 2,801 & 0 & 2,230 & 0,572 & & & & & & & \\
\hline 1/8/2017 19:00 & 2,796 & 0 & 2,243 & 0,553 & & & & & & & \\
\hline $1 / 8 / 2017 \quad 19: 15$ & 2,769 & 0 & 2,257 & 0,511 & & & & & & & \\
\hline $1 / 8 / 2017 \quad 19: 30$ & 2,761 & 0 & 2,271 & 0,490 & & & & & & & \\
\hline $\begin{array}{ll}1 / 8 / 2017 \quad 19: 45 \\
\end{array}$ & 2,741 & 0 & 2,285 & 0,456 & & & & & & & \\
\hline 1/8/2017 20:00 & 2,701 & 0 & 2,299 & 0,401 & & & & & & & \\
\hline $1 / 8 / 2017 \quad 20: 15$ & 2,678 & 0 & 2,313 & 0,365 & & & & & & & \\
\hline
\end{tabular}




\begin{tabular}{|c|c|c|c|c|c|c|c|c|c|c|c|}
\hline Waktu & $\begin{array}{c}\mathbf{Q} \\
(\mathrm{m} 3 / \mathbf{s})\end{array}$ & $\begin{array}{c}\mathbf{P} \\
(\mathbf{m m})\end{array}$ & $\begin{array}{c}\text { Baseflow } \\
(\mathrm{m} 3 / \mathbf{s})\end{array}$ & $\begin{array}{c}\text { DRO } \\
(\mathrm{m} 3 / \mathrm{s})\end{array}$ & $\begin{array}{c}\text { Total } \\
\text { DRO } \\
(\mathrm{m} 3 / \mathbf{s})\end{array}$ & $\begin{array}{c}\text { Volume } \\
\text { DRO } \\
\text { (m3) }\end{array}$ & $\begin{array}{c}\text { Luas DTA } \\
\quad(\mathbf{m} 2)\end{array}$ & $\begin{array}{l}\text { Tebal } \\
\text { DRO } \\
(\mathbf{m m}) \\
\end{array}$ & $\begin{array}{c}\phi(\mathrm{mm} / \\
15 \\
\text { menit })\end{array}$ & $\begin{array}{c}\text { Hujan } \\
\text { efektif } \\
(\mathbf{m m})\end{array}$ & $\begin{array}{l}\text { Total } \\
\text { Hujan } \\
\text { Efetif }\end{array}$ \\
\hline 1/8/2017 20:30 & 2,665 & 0 & 2,327 & 0,338 & & & & & & & \\
\hline 1/8/2017 20:45 & 2,653 & 0 & 2,341 & 0,312 & & & & & & & \\
\hline 1/8/2017 21:00 & 2,640 & 0 & 2,355 & 0,285 & & & & & & & \\
\hline $1 / 8 / 2017 \quad 21: 15$ & 2,625 & 0 & 2,369 & 0,256 & & & & & & & \\
\hline 1/8/2017 21:30 & 2,635 & 0 & 2,383 & 0,253 & & & & & & & \\
\hline $1 / 8 / 2017 \quad 21: 45$ & 2,628 & 0 & 2,397 & 0,231 & & & & & & & \\
\hline 1/8/2017 22:00 & 2,620 & 0 & 2,411 & 0,210 & & & & & & & \\
\hline 1/8/2017 22:15 & 2,610 & 0 & 2,424 & 0,186 & & & & & & & \\
\hline 1/8/2017 22:30 & 2,577 & 0 & 2,438 & 0,139 & & & & & & & \\
\hline 1/8/2017 22:45 & 2,560 & 0 & 2,452 & 0,107 & & & & & & & \\
\hline 1/8/2017 23:00 & 2,555 & 0 & 2,466 & 0,088 & & & & & & & \\
\hline 1/8/2017 23:15 & 2,524 & 0 & 2,480 & 0,044 & & & & & & & \\
\hline
\end{tabular}




\section{Lampiran 4. Perhitungan Hujan Efektif Sinking Stream Kedungbuntung}

Waktu awal hujan 14 Januari 2017 21:00

\begin{tabular}{|c|c|c|c|c|c|c|c|c|c|c|c|}
\hline Waktu & $\mathrm{Q}(\mathrm{m} 3 / \mathrm{s})$ & $\mathbf{P}(\mathbf{m m})$ & $\begin{array}{c}\text { Baseflow } \\
(\mathrm{m} 3 / \mathrm{s})\end{array}$ & $\begin{array}{c}\text { DRO } \\
(\mathrm{m} 3 / \mathbf{s})\end{array}$ & $\begin{array}{c}\text { Total } \\
\text { DRO } \\
(\mathrm{m} 3 / \mathrm{s})\end{array}$ & $\begin{array}{c}\text { Volume } \\
\text { DRO (m3) }\end{array}$ & $\begin{array}{l}\text { Luas } \\
\text { DTA } \\
(\mathbf{m} 2)\end{array}$ & $\begin{array}{l}\text { Tebal } \\
\text { DRO } \\
(\mathrm{mm})\end{array}$ & $\begin{array}{c}\phi(\mathrm{mm} / \\
15 \\
\text { menit })\end{array}$ & $\begin{array}{c}\text { Hujan } \\
\text { efektif } \\
(\mathbf{m m})\end{array}$ & $\begin{array}{l}\text { Total } \\
\text { Hujan } \\
\text { Efetif }\end{array}$ \\
\hline 1/14/2017 21:00 & 1,930 & 0,4 & 1,930 & 0,000 & 27,625 & 24862,0529 & 13690000 & 1,82 & 6,59 & & 1,82 \\
\hline 1/14/2017 21:15 & 1,933 & & 1,933 & 0,000 & & & & & & & \\
\hline $1 / 14 / 2017 \quad 21: 30$ & 1,927 & 0,8 & 1,927 & 0,000 & & & & & & & \\
\hline 1/14/2017 21:45 & 2,019 & 8 & 1,938 & 0,082 & & & & & & 1,41 & \\
\hline 1/14/2017 22:00 & 2,132 & 7 & 1,948 & 0,184 & & & & & & 0,41 & \\
\hline 1/14/2017 22:15 & 2,210 & 1,8 & 1,958 & 0,253 & & & & & & & \\
\hline 1/14/2017 22:30 & 2,474 & 0,8 & 1,968 & 0,506 & & & & & & & \\
\hline 1/14/2017 22:45 & 2,713 & 0,8 & 1,978 & 0,735 & & & & & & & \\
\hline 1/14/2017 23:00 & 2,746 & 0,4 & 1,988 & 0,758 & & & & & & & \\
\hline 1/14/2017 23:15 & 2,723 & 0,4 & 1,998 & 0,725 & & & & & & & \\
\hline $1 / 14 / 2017 \quad 23: 30$ & 2,819 & 1 & 2,008 & 0,810 & & & & & & & \\
\hline 1/14/2017 23:45 & 3,256 & 0,4 & 2,018 & 1,238 & & & & & & & \\
\hline 1/15/2017 $0: 00$ & 3,341 & 0,2 & 2,029 & 1,312 & & & & & & & \\
\hline $1 / 15 / 2017 \quad 0: 15$ & 3,281 & 0,2 & 2,039 & 1,242 & & & & & & & \\
\hline 1/15/2017 $0: 30$ & 3,211 & 0,2 & 2,049 & 1,163 & & & & & & & \\
\hline $1 / 15 / 2017 \quad 0: 45$ & 3,191 & 0,2 & 2,059 & 1,132 & & & & & & & \\
\hline 1/15/2017 1:00 & 3,154 & & 2,069 & 1,085 & & & & & & & \\
\hline $1 / 15 / 2017 \quad 1: 15$ & 3,124 & & 2,079 & 1,045 & & & & & & & \\
\hline $1 / 15 / 2017 \quad 1: 30$ & 3,092 & & 2,089 & 1,002 & & & & & & & \\
\hline $1 / 15 / 2017 \quad 1: 45$ & 3,067 & & 2,099 & 0,967 & & & & & & & \\
\hline $1 / 15 / 2017 \quad 2: 00$ & 3,014 & & 2,110 & 0,905 & & & & & & & \\
\hline $1 / 15 / 2017 \quad 2: 15$ & 2,974 & & 2,120 & 0,854 & & & & & & & \\
\hline
\end{tabular}




\begin{tabular}{|c|c|c|c|c|c|c|c|c|c|c|c|}
\hline Waktu & $Q(\mathbf{m} 3 / \mathbf{s})$ & $\mathbf{P}(\mathbf{m m})$ & $\begin{array}{c}\text { Baseflow } \\
(\mathrm{m} 3 / \mathrm{s})\end{array}$ & $\begin{array}{l}\text { DRO } \\
(\mathrm{m} 3 / \mathbf{s})\end{array}$ & $\begin{array}{l}\text { Total } \\
\text { DRO } \\
(\mathrm{m} 3 / \mathrm{s}) \\
\end{array}$ & $\begin{array}{c}\text { Volume } \\
\text { DRO (m3) }\end{array}$ & $\begin{array}{l}\text { Luas } \\
\text { DTA } \\
(\mathrm{m} 2) \\
\end{array}$ & $\begin{array}{l}\text { Tebal } \\
\text { DRO } \\
(\mathrm{mm}) \\
\end{array}$ & $\begin{array}{c}\phi(\mathrm{mm} / \\
15 \\
\text { menit })\end{array}$ & $\begin{array}{c}\text { Hujan } \\
\text { efektif } \\
(\mathrm{mm})\end{array}$ & $\begin{array}{c}\text { Total } \\
\text { Hujan } \\
\text { Efetif } \\
\end{array}$ \\
\hline $1 / 15 / 2017 \quad 2: 30$ & 2,952 & 0,2 & 2,130 & 0,822 & & & & & & & \\
\hline $1 / 15 / 2017 \quad 2: 45$ & 2,917 & & 2,140 & 0,777 & & & & & & & \\
\hline $1 / 15 / 2017 \quad 3: 00$ & 2,881 & & 2,150 & 0,731 & & & & & & & \\
\hline $1 / 15 / 2017 \quad 3: 15$ & 2,839 & & 2,160 & 0,679 & & & & & & & \\
\hline $1 / 15 / 2017 \quad 3: 30$ & 2,831 & 0,2 & 2,170 & 0,661 & & & & & & & \\
\hline $1 / 15 / 2017 \quad 3: 45$ & 2,811 & & 2,180 & 0,631 & & & & & & & \\
\hline 1/15/2017 4:00 & 2,781 & 0,2 & 2,190 & 0,591 & & & & & & & \\
\hline $1 / 15 / 2017 \quad 4: 15$ & 2,761 & & 2,201 & 0,560 & & & & & & & \\
\hline $1 / 15 / 2017 \quad 4: 30$ & 2,741 & & 2,211 & 0,530 & & & & & & & \\
\hline 1/15/2017 $4: 45$ & 2,708 & & 2,221 & 0,487 & & & & & & & \\
\hline 1/15/2017 5:00 & 2,716 & & 2,231 & 0,485 & & & & & & & \\
\hline 1/15/2017 5:15 & 2,678 & & 2,241 & 0,437 & & & & & & & \\
\hline $1 / 15 / 20175: 30$ & 2,670 & & 2,251 & 0,419 & & & & & & & \\
\hline $1 / 15 / 2017 \quad 5: 45$ & 2,645 & & 2,261 & 0,384 & & & & & & & \\
\hline 1/15/2017 6:00 & 2,633 & & 2,271 & 0,361 & & & & & & & \\
\hline 1/15/2017 6:15 & 2,618 & & 2,282 & 0,336 & & & & & & & \\
\hline 1/15/2017 $6: 30$ & 2,615 & & 2,292 & 0,323 & & & & & & & \\
\hline $1 / 15 / 2017 \quad 6: 45$ & 2,587 & & 2,302 & 0,286 & & & & & & & \\
\hline $1 / 15 / 2017 \quad 7: 00$ & 2,572 & & 2,312 & 0,260 & & & & & & & \\
\hline $1 / 15 / 2017 \quad 7: 15$ & 2,572 & & 2,322 & 0,250 & & & & & & & \\
\hline $1 / 15 / 2017 \quad 7: 30$ & 2,565 & & 2,332 & 0,233 & & & & & & & \\
\hline $1 / 15 / 2017 \quad 7: 45$ & 2,542 & & 2,342 & 0,200 & & & & & & & \\
\hline 1/15/2017 8:00 & 2,545 & & 2,352 & 0,192 & & & & & & & \\
\hline $1 / 15 / 2017 \quad 8: 15$ & 2,545 & & 2,363 & 0,182 & & & & & & & \\
\hline $1 / 15 / 2017 \quad 8: 30$ & 2,532 & & 2,373 & 0,159 & & & & & & & \\
\hline $1 / 15 / 2017 \quad 8: 45$ & 2,504 & & 2,383 & 0,121 & & & & & & & \\
\hline
\end{tabular}




\begin{tabular}{|c|c|c|c|c|c|c|c|c|c|c|c|}
\hline Waktu & $\mathrm{Q}(\mathrm{m} 3 / \mathbf{s})$ & $\mathbf{P}(\mathbf{m m})$ & $\begin{array}{c}\text { Baseflow } \\
(\mathbf{m} 3 / \mathbf{s})\end{array}$ & $\begin{array}{c}\text { DRO } \\
(\mathrm{m} 3 / \mathrm{s})\end{array}$ & 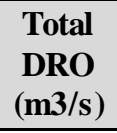 & $\begin{array}{c}\text { Volume } \\
\text { DRO }(\mathrm{m} 3)\end{array}$ & $\begin{array}{l}\text { Luas } \\
\text { DTA } \\
(\mathrm{m} 2) \\
\end{array}$ & $\begin{array}{l}\text { Tebal } \\
\text { DRO } \\
(\mathbf{m m}) \\
\end{array}$ & $\begin{array}{c}\phi(\mathrm{mm} / \\
15 \\
\text { menit })\end{array}$ & $\begin{array}{c}\text { Hujan } \\
\text { efektif } \\
(\mathbf{m m})\end{array}$ & $\begin{array}{c}\text { Total } \\
\text { Hujan } \\
\text { Efetif }\end{array}$ \\
\hline 1/15/2017 9:00 & 2,502 & & 2,393 & 0,109 & & & & & & & \\
\hline 1/15/2017 9:15 & 2,507 & & 2,403 & 0,104 & & & & & & & \\
\hline 1/15/2017 9:30 & 2,504 & & 2,413 & 0,091 & & & & & & & \\
\hline 1/15/2017 9:45 & 2,499 & & 2,423 & 0,076 & & & & & & & \\
\hline 1/15/2017 10:00 & 2,486 & & 2,433 & 0,053 & & & & & & & \\
\hline 1/15/2017 $10: 15$ & 2,494 & & 2,443 & 0,051 & & & & & & & \\
\hline $1 / 15 / 2017 \quad 10: 30$ & 2,479 & & 2,454 & 0,025 & & & & & & & \\
\hline $\begin{array}{lll}1 / 15 / 2017 & 10: 45\end{array}$ & 2,484 & & 2,464 & 0,020 & & & & & & & \\
\hline
\end{tabular}


Lampiran 4. Perhitungan Hujan Efektif Sinking Stream Kedungbuntung

Waktu awal hujan 3 Februari 2017 02:15

\begin{tabular}{|c|c|c|c|c|c|c|c|c|c|c|c|}
\hline Waktu & $\begin{array}{c}\mathbf{Q} \\
(\mathrm{m} 3 / \mathbf{s})\end{array}$ & $\mathbf{P}(\mathbf{m m})$ & $\begin{array}{c}\text { Bas eflow } \\
(\mathrm{m} 3 / \mathrm{s})\end{array}$ & $\begin{array}{c}\text { DRO } \\
(\mathrm{m} 3 / \mathrm{s})\end{array}$ & $\begin{array}{l}\text { Total } \\
\text { DRO } \\
(\mathrm{m} 3 / \mathrm{s})\end{array}$ & $\begin{array}{c}\text { Volume } \\
\text { DRO (m3) }\end{array}$ & $\begin{array}{l}\text { Luas } \\
\text { DTA } \\
(\mathrm{m} 2)\end{array}$ & $\begin{array}{l}\text { Tebal } \\
\text { DRO } \\
(\mathrm{mm})\end{array}$ & $\begin{array}{c}\phi(\mathrm{mm} / \\
15 \\
\text { menit })\end{array}$ & $\begin{array}{c}\text { Hujan } \\
\text { efektif } \\
\text { (mm) }\end{array}$ & $\begin{array}{l}\text { Total } \\
\text { Hujan } \\
\text { Efetif }\end{array}$ \\
\hline $2 / 3 / 2017 \quad 2: 15$ & 2,469 & 0,2 & 2,469 & 0,000 & 51,641 & 46476,64507 & 13690000 & 3,39 & 4,54 & & 3,39 \\
\hline $2 / 3 / 2017 \quad 2: 30$ & 2,469 & & 2,469 & 0,000 & & & & & & & \\
\hline $2 / 3 / 2017 \quad 2: 45$ & 2,514 & 6,8 & 2,471 & 0,043 & & & & & & 2,26 & \\
\hline $2 / 3 / 2017 \quad 3: 00$ & 2,570 & 5,2 & 2,474 & 0,096 & & & & & & 0,66 & \\
\hline $2 / 3 / 2017 \quad 3: 15$ & 2,635 & 5 & 2,477 & 0,158 & & & & & & 0,46 & \\
\hline $2 / 3 / 20173: 30$ & 2,894 & 1,8 & 2,480 & 0,414 & & & & & & & \\
\hline $2 / 3 / 2017 \quad 3: 45$ & 4,019 & 1,2 & 2,482 & 1,537 & & & & & & & \\
\hline 2/3/2017 4:00 & 4,902 & 1 & 2,485 & 2,417 & & & & & & & \\
\hline $2 / 3 / 2017 \quad 4: 15$ & 5,401 & 0,8 & 2,488 & 2,913 & & & & & & & \\
\hline $2 / 3 / 2017 \quad 4: 30$ & 5,617 & 0,4 & 2,490 & 3,126 & & & & & & & \\
\hline 2/3/2017 4:45 & 5,542 & 0,4 & 2,493 & 3,048 & & & & & & & \\
\hline 2/3/2017 5:00 & 5,396 & 0,2 & 2,496 & 2,900 & & & & & & & \\
\hline 2/3/2017 5:15 & 5,267 & 0,4 & 2,499 & 2,769 & & & & & & & \\
\hline $2 / 3 / 2017 \quad 5: 30$ & 5,060 & 0,2 & 2,501 & 2,559 & & & & & & & \\
\hline $2 / 3 / 2017 \quad 5: 45$ & 4,863 & & 2,504 & 2,359 & & & & & & & \\
\hline $2 / 3 / 2017 \quad 6: 00$ & 4,584 & & 2,507 & 2,078 & & & & & & & \\
\hline 2/3/2017 6:15 & 4,351 & & 2,509 & 1,842 & & & & & & & \\
\hline $2 / 3 / 2017 \quad 6: 30$ & 4,135 & & 2,512 & 1,623 & & & & & & & \\
\hline $2 / 3 / 2017 \quad 6: 45$ & 3,958 & & 2,515 & 1,443 & & & & & & & \\
\hline 2/3/2017 7:00 & 3,861 & & 2,517 & 1,344 & & & & & & & \\
\hline 2/3/2017 7:15 & 3,780 & & 2,520 & 1,260 & & & & & & & \\
\hline $2 / 3 / 2017 \quad 7: 30$ & 3,706 & & 2,523 & 1,183 & & & & & & & \\
\hline 2/3/2017 7:45 & 3,629 & & 2,526 & 1,103 & & & & & & & \\
\hline 2/3/2017 8:00 & 3,547 & & 2,528 & 1,019 & & & & & & & \\
\hline
\end{tabular}




\begin{tabular}{|c|c|c|c|c|c|c|c|c|c|c|c|}
\hline Waktu & $\begin{array}{c}\mathbf{Q} \\
(\mathrm{m} 3 / \mathrm{s})\end{array}$ & $\mathbf{P}(\mathbf{m m})$ & $\begin{array}{c}\text { Bas eflow } \\
(\mathrm{m} 3 / \mathrm{s})\end{array}$ & $\begin{array}{c}\text { DRO } \\
(\mathrm{m} 3 / \mathrm{s})\end{array}$ & $\begin{array}{c}\text { Total } \\
\text { DRO } \\
(\mathrm{m} 3 / \mathbf{s})\end{array}$ & $\begin{array}{c}\text { Volume } \\
\text { DRO (m3) }\end{array}$ & $\begin{array}{l}\text { Luas } \\
\text { DTA } \\
\text { (m2) }\end{array}$ & $\begin{array}{l}\text { Tebal } \\
\text { DRO } \\
(\mathrm{mm})\end{array}$ & $\begin{array}{c}\phi(\mathrm{mm} / \\
15 \\
\text { menit })\end{array}$ & $\begin{array}{c}\begin{array}{c}\text { Hujan } \\
\text { efektif } \\
(\mathrm{mm})\end{array} \\
\end{array}$ & $\begin{array}{c}\text { Total } \\
\text { Hujan } \\
\text { Efetif }\end{array}$ \\
\hline $2 / 3 / 20178: 15$ & 3,485 & & 2,531 & 0,954 & & & & & & & \\
\hline $2 / 3 / 20178: 30$ & 3,438 & & 2,534 & 0,904 & & & & & & & \\
\hline $2 / 3 / 2017 \quad 8: 45$ & 3,371 & & 2,536 & 0,834 & & & & & & & \\
\hline 2/3/2017 9:00 & 3,348 & & 2,539 & 0,809 & & & & & & & \\
\hline $2 / 3 / 2017 \quad 9: 15$ & 3,304 & & 2,542 & 0,762 & & & & & & & \\
\hline $2 / 3 / 2017 \quad 9: 30$ & 3,249 & & 2,545 & 0,704 & & & & & & & \\
\hline $2 / 3 / 2017 \quad 9: 45$ & 3,219 & & 2,547 & 0,672 & & & & & & & \\
\hline 2/3/2017 10:00 & 3,171 & & 2,550 & 0,621 & & & & & & & \\
\hline $2 / 3 / 2017 \quad 10: 15$ & 3,152 & & 2,553 & 0,599 & & & & & & & \\
\hline $2 / 3 / 2017 \quad 10: 30$ & 3,104 & & 2,555 & 0,549 & & & & & & & \\
\hline 2/3/2017 10:45 & 3,079 & & 2,558 & 0,521 & & & & & & & \\
\hline 2/3/2017 11:00 & 3,057 & & 2,561 & 0,496 & & & & & & & \\
\hline 2/3/2017 11:15 & 3,014 & & 2,564 & 0,451 & & & & & & & \\
\hline 2/3/2017 11:30 & 2,994 & & 2,566 & 0,428 & & & & & & & \\
\hline 2/3/2017 11:45 & 2,962 & & 2,569 & 0,393 & & & & & & & \\
\hline 2/3/2017 12:00 & 2,987 & 0,2 & 2,572 & 0,415 & & & & & & & \\
\hline 2/3/2017 12:15 & 2,944 & & 2,574 & 0,370 & & & & & & & \\
\hline 2/3/2017 12:30 & 2,919 & & 2,577 & 0,342 & & & & & & & \\
\hline 2/3/2017 12:45 & 2,896 & & 2,580 & 0,317 & & & & & & & \\
\hline 2/3/2017 13:00 & 2,874 & & 2,582 & 0,291 & & & & & & & \\
\hline 2/3/2017 13:15 & 2,861 & & 2,585 & 0,276 & & & & & & & \\
\hline 2/3/2017 13:30 & 2,856 & & 2,588 & 0,268 & & & & & & & \\
\hline 2/3/2017 13:45 & 2,851 & & 2,591 & 0,261 & & & & & & & \\
\hline 2/3/2017 14:00 & 2,844 & & 2,593 & 0,251 & & & & & & & \\
\hline $2 / 3 / 2017 \quad 14: 15$ & 2,824 & & 2,596 & 0,228 & & & & & & & \\
\hline $2 / 3 / 2017 \quad 14: 30$ & 2,814 & & 2,599 & 0,215 & & & & & & & \\
\hline
\end{tabular}




\begin{tabular}{|c|c|c|c|c|c|c|c|c|c|c|c|}
\hline Waktu & $\underset{(\mathrm{m} 3 / \mathbf{s})}{\mathbf{Q}}$ & $\mathbf{P}(\mathbf{m m})$ & $\begin{array}{c}\text { Baseflow } \\
(\mathrm{m} 3 / \mathrm{s})\end{array}$ & $\begin{array}{c}\text { DRO } \\
(\mathrm{m} 3 / \mathrm{s})\end{array}$ & $\begin{array}{c}\text { Total } \\
\text { DRO } \\
(\mathrm{m} 3 / \mathbf{s})\end{array}$ & $\begin{array}{c}\text { Volume } \\
\text { DRO (m3) }\end{array}$ & $\begin{array}{l}\text { Luas } \\
\text { DTA } \\
(\mathrm{m} 2) \\
\end{array}$ & $\begin{array}{l}\text { Tebal } \\
\text { DRO } \\
(\mathbf{m m})\end{array}$ & $\begin{array}{c}\phi(\mathrm{mm} / \\
15 \\
\text { menit) }\end{array}$ & $\begin{array}{c}\text { Hujan } \\
\text { efektif } \\
(\mathbf{m m})\end{array}$ & $\begin{array}{c}\text { Total } \\
\text { Hujan } \\
\text { Efetif }\end{array}$ \\
\hline $2 / 3 / 2017 \quad 14: 45$ & 2,804 & & 2,601 & 0,202 & & & & & & & \\
\hline 2/3/2017 15:00 & 2,794 & & 2,604 & 0,190 & & & & & & & \\
\hline 2/3/2017 15:15 & 2,774 & & 2,607 & 0,167 & & & & & & & \\
\hline 2/3/2017 $\quad 15: 30$ & 2,771 & & 2,610 & 0,161 & & & & & & & \\
\hline 2/3/2017 $\quad 15: 45$ & 2,753 & & 2,612 & 0,141 & & & & & & & \\
\hline 2/3/2017 $\quad 16: 00$ & 2,733 & & 2,615 & 0,118 & & & & & & & \\
\hline 2/3/2017 $\quad 16: 15$ & 2,748 & & 2,618 & 0,131 & & & & & & & \\
\hline $2 / 3 / 2017 \quad 16: 30$ & 2,731 & & 2,620 & 0,110 & & & & & & & \\
\hline $2 / 3 / 2017 \quad 16: 45$ & 2,716 & & 2,623 & 0,093 & & & & & & & \\
\hline 2/3/2017 $\quad 17: 00$ & 2,716 & & 2,626 & 0,090 & & & & & & & \\
\hline 2/3/2017 17:15 & 2,703 & 0,2 & 2,628 & 0,075 & & & & & & & \\
\hline $3 / 2 / 17 \quad 17: 30$ & 2,716 & 0 & 2,631 & 0,085 & & & & & & & \\
\hline $3 / 2 / 17 \quad 17: 45$ & 2,696 & 1,2 & 2,634 & 0,062 & & & & & & & \\
\hline 3/2/17 18:00 & 2,688 & 0 & 2,637 & 0,051 & & & & & & & \\
\hline $3 / 2 / 17 \quad 18: 15$ & 2,691 & 0 & 2,639 & 0,051 & & & & & & & \\
\hline $3 / 2 / 17 \quad 18: 30$ & 2,676 & 0 & 2,642 & 0,033 & & & & & & & \\
\hline $3 / 2 / 17 \quad 18: 45$ & 2,670 & 0 & 2,645 & 0,026 & & & & & & & \\
\hline 3/2/17 19:00 & 2,673 & 0 & 2,647 & 0,026 & & & & & & & \\
\hline $3 / 2 / 17 \quad 19: 15$ & 2,658 & 0 & 2,650 & 0,008 & & & & & & & \\
\hline
\end{tabular}


Lampiran 4. Perhitungan Hujan Efektif Sinking Stream Kedungbuntung

Waktu awal hujan 28 Februari 2017 20:45

\begin{tabular}{|c|c|c|c|c|c|c|c|c|c|c|c|}
\hline Waktu & $Q(\mathbf{m} 3 / \mathbf{s})$ & $\mathbf{P}(\mathbf{m m})$ & $\begin{array}{c}\text { Bas eflow } \\
(\mathrm{m} 3 / \mathrm{s})\end{array}$ & $\begin{array}{c}\text { DRO } \\
(\mathrm{m} 3 / \mathrm{s})\end{array}$ & $\begin{array}{c}\text { Total } \\
\text { DRO } \\
(\mathrm{m} 3 / \mathrm{s})\end{array}$ & $\begin{array}{c}\text { Volume } \\
\text { DRO } \\
\text { (m3) }\end{array}$ & $\begin{array}{l}\text { Luas DTA } \\
\quad(\mathbf{m} 2)\end{array}$ & $\begin{array}{l}\text { Tebal } \\
\text { DRO } \\
(\mathrm{mm})\end{array}$ & $\begin{array}{c}\phi(\mathrm{mm} / \\
15 \\
\text { menit })\end{array}$ & $\begin{array}{c}\text { Hujan } \\
\text { efektif } \\
(\mathbf{m m})\end{array}$ & $\begin{array}{l}\text { Total } \\
\text { Hujan } \\
\text { Efetif }\end{array}$ \\
\hline 2/28/2017 19:45 & 2,309 & & 2,309 & 0,000 & 14,161 & 12.745 & 13.690 .000 & 0,93 & 7,47 & & 0,93 \\
\hline 2/28/2017 20:00 & 2,312 & & 2,312 & 0,000 & & & & & & & \\
\hline 2/28/2017 20:15 & 2,309 & & 2,309 & 0,000 & & & & & & & \\
\hline 2/28/2017 20:30 & 2,304 & 2 & 2,304 & 0,000 & & & & & & & \\
\hline $2 / 28 / 2017 \quad 20: 45$ & 2,319 & 8,4 & 2,311 & 0,008 & & & & & & 0,93 & \\
\hline 2/28/2017 21:00 & 2,347 & 5,8 & 2,319 & 0,029 & & & & & & & \\
\hline 2/28/2017 21:15 & 2,370 & 2,4 & 2,326 & 0,044 & & & & & & & \\
\hline $2 / 28 / 2017 \quad 21: 30$ & 2,398 & 0,4 & 2,333 & 0,065 & & & & & & & \\
\hline 2/28/2017 21:45 & 2,416 & 0,4 & 2,340 & 0,076 & & & & & & & \\
\hline 2/28/2017 22:00 & 2,489 & & 2,347 & 0,142 & & & & & & & \\
\hline $2 / 28 / 2017 \quad 22: 15$ & 2,550 & & 2,355 & 0,195 & & & & & & & \\
\hline 2/28/2017 22:30 & 2,572 & & 2,362 & 0,211 & & & & & & & \\
\hline $2 / 28 / 2017 \quad 22: 45$ & 2,608 & & 2,369 & 0,239 & & & & & & & \\
\hline 2/28/2017 23:00 & 2,791 & & 2,376 & 0,415 & & & & & & & \\
\hline 2/28/2017 23:15 & 3,119 & & 2,383 & 0,736 & & & & & & & \\
\hline 2/28/2017 23:30 & 3,254 & & 2,390 & 0,863 & & & & & & & \\
\hline 2/28/2017 23:45 & 3,211 & & 2,398 & 0,814 & & & & & & & \\
\hline 3/1/2017 0:00 & 3,194 & & 2,405 & 0,789 & & & & & & & \\
\hline 3/1/2017 $0: 15$ & 3,154 & & 2,412 & 0,742 & & & & & & & \\
\hline $3 / 1 / 2017 \quad 0: 30$ & 3,129 & & 2,419 & 0,710 & & & & & & & \\
\hline 3/1/2017 $0: 45$ & 3,102 & & 2,426 & 0,675 & & & & & & & \\
\hline 3/1/2017 1:00 & 3,064 & & 2,433 & 0,631 & & & & & & & \\
\hline $3 / 1 / 2017 \quad 1: 15$ & 3,044 & & 2,441 & 0,603 & & & & & & & \\
\hline $3 / 1 / 2017 \quad 1: 30$ & 2,989 & & 2,448 & 0,541 & & & & & & & \\
\hline
\end{tabular}




\begin{tabular}{|c|c|c|c|c|c|c|c|c|c|c|c|}
\hline Waktu & $\mathrm{Q}(\mathrm{m} 3 / \mathrm{s})$ & $\mathbf{P}(\mathbf{m m})$ & $\begin{array}{c}\text { Bas eflow } \\
(\mathrm{m} 3 / \mathbf{s})\end{array}$ & $\begin{array}{c}\text { DRO } \\
(\mathrm{m} 3 / \mathrm{s})\end{array}$ & $\begin{array}{c}\text { Total } \\
\text { DRO } \\
(\mathrm{m} 3 / \mathrm{s}) \\
\end{array}$ & $\begin{array}{c}\text { Volume } \\
\text { DRO } \\
(\mathrm{m3})\end{array}$ & $\begin{array}{l}\text { Luas DTA } \\
\text { (m2) }\end{array}$ & $\begin{array}{l}\text { Tebal } \\
\text { DRO } \\
(\mathrm{mm}) \\
\end{array}$ & $\begin{array}{c}\phi(\mathrm{mm} / \\
15 \\
\text { menit })\end{array}$ & $\begin{array}{c}\begin{array}{c}\text { Hujan } \\
\text { efektif } \\
(\mathrm{mm})\end{array} \\
\end{array}$ & $\begin{array}{l}\text { Total } \\
\text { Hujan } \\
\text { Efetif }\end{array}$ \\
\hline 3/1/2017 1:45 & 2,974 & & 2,455 & 0,519 & & & & & & & \\
\hline $3 / 1 / 2017 \quad 2: 00$ & 2,922 & & 2,462 & 0,459 & & & & & & & \\
\hline $3 / 1 / 2017 \quad 2: 15$ & 2,909 & & 2,469 & 0,440 & & & & & & & \\
\hline $3 / 1 / 2017 \quad 2: 30$ & 2,889 & & 2,477 & 0,412 & & & & & & & \\
\hline $3 / 1 / 2017 \quad 2: 45$ & 2,876 & & 2,484 & 0,393 & & & & & & & \\
\hline 3/1/2017 3:00 & 2,856 & & 2,491 & 0,365 & & & & & & & \\
\hline 3/1/2017 3:15 & 2,854 & & 2,498 & 0,356 & & & & & & & \\
\hline $3 / 1 / 2017 \quad 3: 30$ & 2,824 & & 2,505 & 0,318 & & & & & & & \\
\hline $3 / 1 / 2017 \quad 3: 45$ & 2,836 & & 2,512 & 0,324 & & & & & & & \\
\hline 3/1/2017 4:00 & 2,811 & & 2,520 & 0,292 & & & & & & & \\
\hline 3/1/2017 4:15 & 2,804 & & 2,527 & 0,277 & & & & & & & \\
\hline $3 / 1 / 2017 \quad 4: 30$ & 2,799 & & 2,534 & 0,265 & & & & & & & \\
\hline 3/1/2017 4:45 & 2,758 & & 2,541 & 0,217 & & & & & & & \\
\hline $3 / 1 / 20175: 00$ & 2,748 & & 2,548 & 0,200 & & & & & & & \\
\hline $3 / 1 / 2017 \quad 5: 15$ & 2,738 & & 2,556 & 0,183 & & & & & & & \\
\hline $3 / 1 / 20175: 30$ & 2,718 & & 2,563 & 0,156 & & & & & & & \\
\hline $3 / 1 / 2017 \quad 5: 45$ & 2,701 & & 2,570 & 0,131 & & & & & & & \\
\hline 3/1/2017 6:00 & 2,676 & & 2,577 & 0,098 & & & & & & & \\
\hline $3 / 1 / 2017 \quad 6: 15$ & 2,668 & & 2,584 & 0,084 & & & & & & & \\
\hline 3/1/2017 6:30 & 2,643 & & 2,591 & 0,051 & & & & & & & \\
\hline $3 / 1 / 2017 \quad 6: 45$ & 2,638 & & 2,599 & 0,039 & & & & & & & \\
\hline 3/1/2017 7:00 & 2,645 & & 2,606 & 0,040 & & & & & & & \\
\hline $3 / 1 / 2017 \quad 7: 15$ & 2,628 & & 2,613 & 0,015 & & & & & & & \\
\hline
\end{tabular}


Lampiran 4. Perhitungan Hujan Efektif Sinking Stream Kedungbuntung

Waktu awal hujan 1 Maret 2017 14:15

\begin{tabular}{|c|c|c|c|c|c|c|c|c|c|c|c|}
\hline Waktu & $\begin{array}{c}\mathbf{Q} \\
(\mathrm{m} 3 / \mathrm{s})\end{array}$ & $\mathbf{P}(\mathbf{m m})$ & $\begin{array}{c}\text { Baseflow } \\
(\mathrm{m} 3 / \mathrm{s})\end{array}$ & $\begin{array}{l}\text { DRO } \\
(\mathrm{m} 3 / \mathrm{s})\end{array}$ & $\begin{array}{l}\text { Total } \\
\text { DRO } \\
(\mathrm{m} 3 / \mathrm{s})\end{array}$ & $\begin{array}{c}\text { Volume } \\
\text { DRO (m3) }\end{array}$ & $\begin{array}{l}\text { Luas } \\
\text { DTA } \\
(\mathbf{m} 2)\end{array}$ & $\begin{array}{l}\text { Tebal } \\
\text { DRO } \\
(\mathrm{mm})\end{array}$ & $\begin{array}{c}\phi(\mathrm{mm} / \\
15 \\
\text { menit })\end{array}$ & $\begin{array}{c}\text { Hujan } \\
\text { efektif } \\
\text { (mm) }\end{array}$ & $\begin{array}{l}\text { Total } \\
\text { Hujan } \\
\text { Efetif }\end{array}$ \\
\hline $3 / 1 / 2017 \quad 14: 15$ & 2,446 & 0,4 & 2,446 & 0,000 & 102,688 & 92419,08083 & 13690000 & 6,75 & 7,62 & & 6,75 \\
\hline $3 / 1 / 2017 \quad 14: 30$ & 2,459 & 3,4 & 2,459 & 0,000 & & & & & & & \\
\hline $3 / 1 / 2017 \quad 14: 45$ & 2,481 & 11,6 & 2,469 & 0,013 & & & & & & 3,98 & \\
\hline $3 / 1 / 2017 \quad 15: 00$ & 2,650 & 10,4 & 2,479 & 0,171 & & & & & & 2,78 & \\
\hline $3 / 1 / 2017 \quad 15: 15$ & 2,874 & 2,6 & 2,489 & 0,385 & & & & & & & \\
\hline $3 / 1 / 2017 \quad 15: 30$ & 5,306 & 1,4 & 2,500 & 2,807 & & & & & & & \\
\hline $3 / 1 / 2017 \quad 15: 45$ & 8,622 & 0,2 & 2,510 & 6,113 & & & & & & & \\
\hline 3/1/2017 16:00 & 10,514 & & 2,520 & 7,994 & & & & & & & \\
\hline 3/1/2017 16:15 & 11,215 & & 2,530 & 8,685 & & & & & & & \\
\hline 3/1/2017 16:30 & 10,899 & & 2,540 & 8,358 & & & & & & & \\
\hline $3 / 1 / 2017 \quad 16: 45$ & 10,237 & & 2,551 & 7,686 & & & & & & & \\
\hline $3 / 1 / 2017 \quad 17: 00$ & 9,502 & & 2,561 & 6,941 & & & & & & & \\
\hline $3 / 1 / 2017 \quad 17: 15$ & 8,848 & & 2,571 & 6,277 & & & & & & & \\
\hline $3 / 1 / 2017 \quad 17: 30$ & 8,181 & & 2,581 & 5,600 & & & & & & & \\
\hline $3 / 1 / 2017 \quad 17: 45$ & 7,535 & & 2,592 & 4,944 & & & & & & & \\
\hline 3/1/2017 18:00 & 6,928 & & 2,602 & 4,326 & & & & & & & \\
\hline $3 / 1 / 2017 \quad 18: 15$ & 6,409 & & 2,612 & 3,797 & & & & & & & \\
\hline $3 / 1 / 2017 \quad 18: 30$ & 5,929 & & 2,622 & 3,307 & & & & & & & \\
\hline $3 / 1 / 2017 \quad 18: 45$ & 5,500 & & 2,632 & 2,868 & & & & & & & \\
\hline 3/1/2017 19:00 & 5,073 & & 2,643 & 2,430 & & & & & & & \\
\hline $3 / 1 / 2017 \quad 19: 15$ & 4,770 & & 2,653 & 2,117 & & & & & & & \\
\hline $3 / 1 / 2017 \quad 19: 30$ & 4,498 & & 2,663 & 1,835 & & & & & & & \\
\hline $3 / 1 / 2017 \quad 19: 45$ & 4,251 & & 2,673 & 1,577 & & & & & & & \\
\hline 3/1/2017 20:00 & 4,059 & & 2,684 & 1,375 & & & & & & & \\
\hline
\end{tabular}




\begin{tabular}{|c|c|c|c|c|c|c|c|c|c|c|c|}
\hline Waktu & $\begin{array}{c}\mathbf{Q} \\
(\mathrm{m} 3 / \mathrm{s})\end{array}$ & $\mathbf{P}(\mathbf{m m})$ & $\begin{array}{c}\text { Baseflow } \\
(\mathrm{m} 3 / \mathrm{s})\end{array}$ & $\begin{array}{l}\text { DRO } \\
(\mathrm{m} 3 / \mathrm{s})\end{array}$ & $\begin{array}{l}\text { Total } \\
\text { DRO } \\
(\mathrm{m} 3 / \mathrm{s}) \\
\end{array}$ & $\begin{array}{c}\text { Volume } \\
\text { DRO (m3) }\end{array}$ & $\begin{array}{l}\text { Luas } \\
\text { DTA } \\
(\mathbf{m} 2)\end{array}$ & $\begin{array}{l}\text { Tebal } \\
\text { DRO } \\
(\mathrm{mm})\end{array}$ & $\begin{array}{c}\phi(\mathrm{mm} / \\
15 \\
\text { menit })\end{array}$ & $\begin{array}{c}\begin{array}{c}\text { Hujan } \\
\text { efektif } \\
(\mathrm{mm})\end{array} \\
\end{array}$ & $\begin{array}{l}\text { Total } \\
\text { Hujan } \\
\text { Efetif }\end{array}$ \\
\hline $3 / 1 / 2017 \quad 20: 15$ & 3,908 & & 2,694 & 1,215 & & & & & & & \\
\hline 3/1/2017 20:30 & 3,822 & 0,8 & 2,704 & 1,118 & & & & & & & \\
\hline 3/1/2017 20:45 & 3,772 & 0,4 & 2,714 & 1,058 & & & & & & & \\
\hline 3/1/2017 21:00 & 3,676 & 1,2 & 2,724 & 0,952 & & & & & & & \\
\hline $3 / 1 / 2017 \quad 21: 15$ & 3,621 & 1,2 & 2,735 & 0,887 & & & & & & & \\
\hline $3 / 1 / 2017 \quad 21: 30$ & 3,557 & 0,6 & 2,745 & 0,812 & & & & & & & \\
\hline $3 / 1 / 2017 \quad 21: 45$ & 3,492 & 0,4 & 2,755 & 0,737 & & & & & & & \\
\hline $3 / 1 / 2017 \quad 22: 00$ & 3,470 & 0,2 & 2,765 & 0,705 & & & & & & & \\
\hline $3 / 1 / 2017 \quad 22: 15$ & 3,445 & & 2,776 & 0,670 & & & & & & & \\
\hline $3 / 1 / 2017 \quad 22: 30$ & 3,410 & & 2,786 & 0,625 & & & & & & & \\
\hline $3 / 1 / 2017 \quad 22: 45$ & 3,403 & 0,2 & 2,796 & 0,607 & & & & & & & \\
\hline 3/1/2017 23:00 & 3,366 & & 2,806 & 0,560 & & & & & & & \\
\hline $3 / 1 / 2017 \quad 23: 15$ & 3,301 & & 2,816 & 0,485 & & & & & & & \\
\hline $3 / 1 / 2017 \quad 23: 30$ & 3,301 & & 2,827 & 0,474 & & & & & & & \\
\hline 3/1/2017 23:45 & 3,266 & & 2,837 & 0,429 & & & & & & & \\
\hline $3 / 2 / 2017 \quad 0: 00$ & 3,206 & & 2,847 & 0,359 & & & & & & & \\
\hline $3 / 2 / 2017 \quad 0: 15$ & 3,161 & & 2,857 & 0,304 & & & & & & & \\
\hline $3 / 2 / 2017 \quad 0: 30$ & 3,142 & & 2,868 & 0,274 & & & & & & & \\
\hline $3 / 2 / 2017 \quad 0: 45$ & 3,132 & & 2,878 & 0,254 & & & & & & & \\
\hline $3 / 2 / 2017 \quad 1: 00$ & 3,077 & & 2,888 & 0,189 & & & & & & & \\
\hline $3 / 2 / 2017 \quad 1: 15$ & 3,042 & & 2,898 & 0,143 & & & & & & & \\
\hline $3 / 2 / 2017 \quad 1: 30$ & 3,027 & & 2,908 & 0,118 & & & & & & & \\
\hline $3 / 2 / 2017 \quad 1: 45$ & 2,987 & & 2,919 & 0,068 & & & & & & & \\
\hline $3 / 2 / 2017 \quad 2: 00$ & 2,969 & & 2,929 & 0,040 & & & & & & & \\
\hline
\end{tabular}


Lampiran 4. Perhitungan Hujan Efektif Sinking Stream Kedungbuntung

Waktu awal hujan 3 Maret 2017 14:00

\begin{tabular}{|c|c|c|c|c|c|c|c|c|c|c|c|}
\hline Waktu & $Q(\mathrm{~m} 3 / \mathrm{s})$ & $\mathbf{P}(\mathbf{m m})$ & $\begin{array}{c}\text { Bas eflow } \\
(\mathrm{m} 3 / \mathrm{s})\end{array}$ & $\begin{array}{c}\text { DRO } \\
(\mathrm{m} 3 / \mathrm{s})\end{array}$ & $\begin{array}{l}\text { Total } \\
\text { DRO } \\
(\mathrm{m} 3 / \mathrm{s})\end{array}$ & $\begin{array}{c}\text { Volume } \\
\text { DRO } \\
\text { (m3) }\end{array}$ & $\begin{array}{l}\text { Luas DTA } \\
\text { (m2) }\end{array}$ & $\begin{array}{l}\text { Tebal } \\
\text { DRO } \\
(\mathrm{mm})\end{array}$ & $\begin{array}{c}\phi(\mathrm{mm} / \\
15 \\
\text { menit })\end{array}$ & $\begin{array}{c}\text { Hujan } \\
\text { efektif } \\
(\mathrm{mm})\end{array}$ & $\begin{array}{l}\text { Total } \\
\text { Hujan } \\
\text { Efetif }\end{array}$ \\
\hline 3/5/2017 14:00 & 2,106 & 2 & 2,106 & 0,000 & 57,843 & 52.058 & 13.690 .000 & 3,80 & 10,40 & & 3,80 \\
\hline $3 / 5 / 2017 \quad 14: 15$ & 2,274 & 14,2 & 2,116 & 0,157 & & & & & & 3,80 & \\
\hline $3 / 5 / 2017 \quad 14: 30$ & 2,509 & 5,2 & 2,127 & 0,382 & & & & & & & \\
\hline $3 / 5 / 2017 \quad 14: 45$ & 2,794 & 0,2 & 2,137 & 0,656 & & & & & & & \\
\hline 3/5/2017 15:00 & 4,135 & & 2,148 & 1,987 & & & & & & & \\
\hline $3 / 5 / 2017 \quad 15: 15$ & 5,748 & & 2,158 & 3,590 & & & & & & & \\
\hline $3 / 5 / 2017 \quad 15: 30$ & 6,644 & & 2,168 & 4,476 & & & & & & & \\
\hline $3 / 5 / 2017 \quad 15: 45$ & 6,630 & & 2,179 & 4,451 & & & & & & & \\
\hline 3/5/2017 16:00 & 6,344 & & 2,189 & 4,155 & & & & & & & \\
\hline $3 / 5 / 2017 \quad 16: 15$ & 6,011 & & 2,200 & 3,812 & & & & & & & \\
\hline $3 / 5 / 2017 \quad 16: 30$ & 5,641 & & 2,210 & 3,431 & & & & & & & \\
\hline $3 / 5 / 2017 \quad 16: 45$ & 5,221 & & 2,220 & 3,001 & & & & & & & \\
\hline 3/5/2017 17:00 & 4,836 & & 2,231 & 2,605 & & & & & & & \\
\hline $3 / 5 / 2017 \quad 17: 15$ & 4,454 & & 2,241 & 2,213 & & & & & & & \\
\hline $3 / 5 / 2017 \quad 17: 30$ & 4,157 & & 2,251 & 1,906 & & & & & & & \\
\hline $3 / 5 / 2017 \quad 17: 45$ & 3,933 & & 2,262 & 1,671 & & & & & & & \\
\hline 3/5/2017 18:00 & 3,824 & & 2,272 & 1,552 & & & & & & & \\
\hline $3 / 5 / 2017 \quad 18: 15$ & 3,708 & & 2,283 & 1,426 & & & & & & & \\
\hline $3 / 5 / 2017 \quad 18: 30$ & 3,612 & & 2,293 & 1,319 & & & & & & & \\
\hline $3 / 5 / 2017 \quad 18: 45$ & 3,527 & & 2,303 & 1,224 & & & & & & & \\
\hline 3/5/2017 19:00 & 3,435 & & 2,314 & 1,122 & & & & & & & \\
\hline 3/5/2017 19:15 & 3,376 & & 2,324 & 1,052 & & & & & & & \\
\hline $3 / 5 / 2017 \quad 19: 30$ & 3,294 & & 2,334 & 0,959 & & & & & & & \\
\hline 3/5/2017 19:45 & 3,264 & & 2,345 & 0,919 & & & & & & & \\
\hline
\end{tabular}




\begin{tabular}{|c|c|c|c|c|c|c|c|c|c|c|c|}
\hline Waktu & $Q(\mathrm{~m} 3 / \mathrm{s})$ & $\mathbf{P}(\mathbf{m m})$ & $\begin{array}{c}\text { Bas eflow } \\
(\mathrm{m} 3 / \mathrm{s})\end{array}$ & $\begin{array}{c}\text { DRO } \\
(\mathrm{m} 3 / \mathrm{s})\end{array}$ & $\begin{array}{l}\text { Total } \\
\text { DRO } \\
(\mathrm{m} 3 / \mathrm{s}) \\
\end{array}$ & $\begin{array}{c}\text { Volume } \\
\text { DRO } \\
(\mathrm{m3}) \\
\end{array}$ & $\begin{array}{l}\text { Luas DTA } \\
\text { (m2) }\end{array}$ & $\begin{array}{l}\text { Tebal } \\
\text { DRO } \\
(\mathrm{mm})\end{array}$ & $\begin{array}{c}\phi(\mathrm{mm} / \\
15 \\
\text { menit })\end{array}$ & $\begin{array}{c}\begin{array}{c}\text { Hujan } \\
\text { efektif } \\
(\mathrm{mm})\end{array} \\
\end{array}$ & $\begin{array}{l}\text { Total } \\
\text { Hujan } \\
\text { Efetif }\end{array}$ \\
\hline 3/5/2017 20:00 & 3,211 & & 2,355 & 0,856 & & & & & & & \\
\hline $3 / 5 / 2017 \quad 20: 15$ & 3,166 & & 2,366 & 0,801 & & & & & & & \\
\hline 3/5/2017 20:30 & 3,132 & & 2,376 & 0,756 & & & & & & & \\
\hline $3 / 5 / 2017 \quad 20: 45$ & 3,072 & & 2,386 & 0,685 & & & & & & & \\
\hline 3/5/2017 21:00 & 3,029 & & 2,397 & 0,632 & & & & & & & \\
\hline $3 / 5 / 2017 \quad 21: 15$ & 3,009 & & 2,407 & 0,602 & & & & & & & \\
\hline $3 / 5 / 2017 \quad 21: 30$ & 2,974 & & 2,418 & 0,557 & & & & & & & \\
\hline $3 / 5 / 2017 \quad 21: 45$ & 2,929 & & 2,428 & 0,501 & & & & & & & \\
\hline 3/5/2017 22:00 & 2,906 & & 2,438 & 0,468 & & & & & & & \\
\hline $3 / 5 / 2017 \quad 22: 15$ & 2,871 & & 2,449 & 0,423 & & & & & & & \\
\hline $3 / 5 / 2017 \quad 22: 30$ & 2,851 & & 2,459 & 0,392 & & & & & & & \\
\hline 3/5/2017 22:45 & 2,844 & & 2,469 & 0,374 & & & & & & & \\
\hline $3 / 5 / 2017 \quad 23: 00$ & 2,834 & & 2,480 & 0,354 & & & & & & & \\
\hline 3/5/2017 23:15 & 2,844 & & 2,490 & 0,354 & & & & & & & \\
\hline $3 / 5 / 2017 \quad 23: 30$ & 2,849 & & 2,501 & 0,348 & & & & & & & \\
\hline $3 / 5 / 2017 \quad 23: 45$ & 2,801 & & 2,511 & 0,290 & & & & & & & \\
\hline 3/6/2017 0:00 & 2,786 & & 2,521 & 0,265 & & & & & & & \\
\hline $3 / 6 / 2017 \quad 0: 15$ & 2,786 & & 2,532 & 0,254 & & & & & & & \\
\hline $3 / 6 / 2017 \quad 0: 30$ & 2,758 & & 2,542 & 0,216 & & & & & & & \\
\hline $3 / 6 / 2017 \quad 0: 45$ & 2,736 & & 2,552 & 0,183 & & & & & & & \\
\hline $3 / 6 / 2017 \quad 1: 00$ & 2,716 & & 2,563 & 0,153 & & & & & & & \\
\hline $3 / 6 / 2017 \quad 1: 15$ & 2,693 & & 2,573 & 0,120 & & & & & & & \\
\hline $3 / 6 / 2017 \quad 1: 30$ & 2,673 & & 2,584 & 0,089 & & & & & & & \\
\hline $3 / 6 / 2017 \quad 1: 45$ & 2,650 & & 2,594 & 0,056 & & & & & & & \\
\hline $3 / 6 / 2017 \quad 2: 00$ & 2,638 & & 2,604 & 0,033 & & & & & & & \\
\hline $3 / 6 / 2017 \quad 2: 15$ & 2,628 & & 2,615 & 0,013 & & & & & & & \\
\hline
\end{tabular}




\section{Lampiran 4. Perhitungan Hujan Efektif Sinking Stream Kedungbuntung}

Waktu awal hujan 17 Maret 2017 17:15

\begin{tabular}{|c|c|c|c|c|c|c|c|c|c|c|c|}
\hline Waktu & $\begin{array}{c}\mathbf{Q} \\
(\mathrm{m} 3 / \mathrm{s})\end{array}$ & $\mathbf{P}(\mathbf{m m})$ & $\begin{array}{c}\text { Bas eflow } \\
(\mathrm{m} 3 / \mathrm{s})\end{array}$ & $\begin{array}{l}\text { DRO } \\
(\mathrm{m} 3 / \mathrm{s})\end{array}$ & $\begin{array}{l}\text { Total } \\
\text { DRO } \\
(\mathbf{m} 3 / \mathbf{s})\end{array}$ & $\begin{array}{c}\text { Volume } \\
\text { DRO (m3) }\end{array}$ & $\begin{array}{l}\text { Luas } \\
\text { DTA } \\
(\mathrm{m} 2)\end{array}$ & $\begin{array}{l}\text { Tebal } \\
\text { DRO } \\
(\mathrm{mm})\end{array}$ & $\begin{array}{c}\phi(\mathrm{mm} / \\
15 \\
\text { menit })\end{array}$ & $\begin{array}{c}\text { Hujan } \\
\text { efektif } \\
\text { (mm) }\end{array}$ & $\begin{array}{l}\text { Total } \\
\text { Hujan } \\
\text { Efetif }\end{array}$ \\
\hline 3/16/2017 16:45 & 1,907 & & 1,907 & 0,000 & 45,034 & 40531,03884 & 13690000 & 2,96 & 5,82 & & 2,96 \\
\hline 3/16/2017 17:00 & 1,920 & & 1,920 & 0,000 & & & & & & & \\
\hline $3 / 16 / 2017 \quad 17: 15$ & 1,968 & 6,4 & 1,931 & 0,037 & & & & & & 0,58 & \\
\hline $3 / 16 / 2017 \quad 17: 30$ & 2,076 & 8,2 & 1,942 & 0,133 & & & & & & 2,38 & \\
\hline $3 / 16 / 2017 \quad 17: 45$ & 2,218 & 5,8 & 1,954 & 0,264 & & & & & & & \\
\hline 3/16/2017 18:00 & 2,319 & 2,6 & 1,965 & 0,355 & & & & & & & \\
\hline $3 / 16 / 2017 \quad 18: 15$ & 2,756 & 0,2 & 1,976 & 0,780 & & & & & & & \\
\hline $3 / 16 / 2017 \quad 18: 30$ & 2,939 & & 1,987 & 0,952 & & & & & & & \\
\hline 3/16/2017 18:45 & 4,393 & & 1,999 & 2,394 & & & & & & & \\
\hline 3/16/2017 19:00 & 4,899 & & 2,010 & 2,889 & & & & & & & \\
\hline $3 / 16 / 2017 \quad 19: 30$ & 4,682 & & 2,033 & 2,649 & & & & & & & \\
\hline 3/16/2017 19:45 & 4,530 & & 2,044 & 2,486 & & & & & & & \\
\hline 3/16/2017 20:00 & 4,332 & 0,2 & 2,055 & 2,276 & & & & & & & \\
\hline 3/16/2017 20:15 & 4,071 & & 2,067 & 2,004 & & & & & & & \\
\hline $3 / 16 / 2017 \quad 20: 30$ & 3,829 & & 2,078 & 1,751 & & & & & & & \\
\hline 3/16/2017 20:45 & 3,659 & & 2,089 & 1,569 & & & & & & & \\
\hline 3/16/2017 21:00 & 3,554 & & 2,100 & 1,454 & & & & & & & \\
\hline
\end{tabular}




\begin{tabular}{|c|c|c|c|c|c|c|c|c|c|c|c|}
\hline $3 / 16 / 2017 \quad 21: 15$ & 3,502 & 0,2 & 2,112 & 1,391 & & & & & & & \\
\hline $3 / 16 / 2017 \quad 21: 30$ & 3,410 & & 2,123 & 1,288 & & & & & & & \\
\hline $3 / 16 / 2017 \quad 21: 45$ & 3,343 & 0,2 & 2,134 & 1,209 & & & & & & & \\
\hline Waktu & $\begin{array}{c}\mathbf{Q} \\
(\mathrm{m} 3 / \mathrm{s})\end{array}$ & $\mathbf{P}(\mathbf{m m})$ & $\begin{array}{c}\text { Bas eflow } \\
(\mathrm{m} 3 / \mathrm{s})\end{array}$ & $\begin{array}{l}\text { DRO } \\
(\mathrm{m} 3 / \mathrm{s})\end{array}$ & $\begin{array}{l}\text { Total } \\
\text { DRO } \\
(\mathrm{m} 3 / \mathrm{s})\end{array}$ & $\begin{array}{c}\text { Volume } \\
\text { DRO (m3) }\end{array}$ & $\begin{array}{l}\text { Luas } \\
\text { DTA } \\
(\mathrm{m} 2)\end{array}$ & $\begin{array}{l}\text { Tebal } \\
\text { DRO } \\
(\mathrm{mm})\end{array}$ & $\begin{array}{c}\phi(\mathrm{mm} / \\
15 \\
\text { menit })\end{array}$ & $\begin{array}{c}\text { Hujan } \\
\text { efektif } \\
(\mathrm{mm})\end{array}$ & $\begin{array}{c}\text { Total } \\
\text { Hujan } \\
\text { Efetif }\end{array}$ \\
\hline $3 / 16 / 2017 \quad 22: 30$ & 3,166 & & 2,168 & 0,998 & & & & & & & \\
\hline $3 / 16 / 2017 \quad 22: 45$ & 3,114 & & 2,179 & 0,935 & & & & & & & \\
\hline 3/16/2017 23:00 & 3,087 & & 2,191 & 0,896 & & & & & & & \\
\hline 3/16/2017 23:15 & 3,052 & 2 & 2,202 & 0,850 & & & & & & & \\
\hline $3 / 16 / 2017 \quad 23: 30$ & 3,007 & & 2,213 & 0,793 & & & & & & & \\
\hline 3/16/2017 23:45 & 2,977 & 0,2 & 2,225 & 0,752 & & & & & & & \\
\hline 3/17/2017 0:00 & 2,947 & & 2,236 & 0,711 & & & & & & & \\
\hline 3/17/2017 $0: 15$ & 2,894 & & 2,247 & 0,647 & & & & & & & \\
\hline 3/17/2017 0:30 & 2,874 & & 2,258 & 0,615 & & & & & & & \\
\hline 3/17/2017 0:45 & 2,851 & & 2,270 & 0,582 & & & & & & & \\
\hline 3/17/2017 1:00 & 2,831 & & 2,281 & 0,550 & & & & & & & \\
\hline $3 / 17 / 2017 \quad 1: 15$ & 2,809 & & 2,292 & 0,516 & & & & & & & \\
\hline $3 / 17 / 2017 \quad 1: 30$ & 2,801 & & 2,304 & 0,498 & & & & & & & \\
\hline $3 / 17 / 2017 \quad 1: 45$ & 2,763 & & 2,315 & 0,449 & & & & & & & \\
\hline $3 / 17 / 2017 \quad 2: 00$ & 2,758 & & 2,326 & 0,432 & & & & & & & \\
\hline $3 / 17 / 2017 \quad 2: 15$ & 2,748 & & 2,338 & 0,411 & & & & & & & \\
\hline $3 / 17 / 2017 \quad 2: 30$ & 2,751 & & 2,349 & 0,402 & & & & & & & \\
\hline $3 / 17 / 2017 \quad 2: 45$ & 2,726 & & 2,360 & 0,366 & & & & & & & \\
\hline $3 / 17 / 2017 \quad 3: 30$ & 2,688 & & 2,394 & 0,294 & & & & & & & \\
\hline
\end{tabular}




\begin{tabular}{|c|c|c|c|c|c|c|c|c|c|c|c|}
\hline $3 / 17 / 2017 \quad 3: 45$ & 2,683 & & 2,405 & 0,278 & & & & & & & \\
\hline $3 / 17 / 2017 \quad 4: 00$ & 2,663 & & 2,417 & 0,246 & & & & & & & \\
\hline $3 / 17 / 2017 \quad 4: 15$ & 2,655 & & 2,428 & 0,228 & & & & & & & \\
\hline Waktu & $\begin{array}{c}\mathbf{Q} \\
(\mathrm{m} 3 / \mathrm{s})\end{array}$ & $\mathbf{P}(\mathbf{m m})$ & $\begin{array}{c}\text { Bas eflow } \\
(\mathrm{m} 3 / \mathrm{s})\end{array}$ & $\begin{array}{l}\text { DRO } \\
(\mathrm{m} 3 / \mathrm{s})\end{array}$ & $\begin{array}{l}\text { Total } \\
\text { DRO } \\
(\mathrm{m} 3 / \mathrm{s})\end{array}$ & $\begin{array}{c}\text { Volume } \\
\text { DRO (m3) }\end{array}$ & $\begin{array}{l}\text { Luas } \\
\text { DTA } \\
(\mathrm{m} 2)\end{array}$ & $\begin{array}{l}\text { Tebal } \\
\text { DRO } \\
(\mathrm{mm})\end{array}$ & $\begin{array}{c}\phi(\mathrm{mm} / \\
15 \\
\text { menit })\end{array}$ & $\begin{array}{c}\text { Hujan } \\
\text { efektif } \\
(\mathrm{mm})\end{array}$ & $\begin{array}{c}\text { Total } \\
\text { Hujan } \\
\text { Efetif }\end{array}$ \\
\hline 3/17/2017 5:00 & 2,610 & & 2,462 & 0,148 & & & & & & & \\
\hline 3/17/2017 5:15 & 2,590 & & 2,473 & 0,117 & & & & & & & \\
\hline $3 / 17 / 2017 \quad 5: 30$ & 2,590 & & 2,484 & 0,106 & & & & & & & \\
\hline 3/17/2017 5:45 & 2,595 & & 2,496 & 0,099 & & & & & & & \\
\hline 3/17/2017 6:00 & 2,577 & & 2,507 & 0,070 & & & & & & & \\
\hline 3/17/2017 6:15 & 2,565 & & 2,518 & 0,046 & & & & & & & \\
\hline 3/17/2017 6:30 & 2,565 & & 2,529 & 0,035 & & & & & & & \\
\hline
\end{tabular}

\section{Lampiran 4. Perhitungan Hujan Efektif Sinking Stream Kedungbuntung}

Waktu awal hujan 26 April 2017 17:45

\begin{tabular}{|c|c|c|c|c|c|c|c|c|c|c|c|}
\hline Waktu & $\mathbf{Q}(\mathbf{m} 3 / \mathbf{s})$ & $\mathbf{P}(\mathbf{m m})$ & $\begin{array}{c}\text { Baseflow } \\
(\mathrm{m} 3 / \mathrm{s})\end{array}$ & $\begin{array}{c}\text { DRO } \\
(\mathrm{m} 3 / \mathbf{s})\end{array}$ & $\begin{array}{c}\text { Total } \\
\text { DRO } \\
(\mathrm{m} 3 / \mathrm{s})\end{array}$ & $\begin{array}{c}\text { Volume } \\
\text { DRO } \\
(\mathrm{m} 3)\end{array}$ & $\begin{array}{c}\text { Luas } \\
\text { DTA (m2) }\end{array}$ & $\begin{array}{c}\text { Tebal DRO } \\
(\mathbf{m m})\end{array}$ & $\begin{array}{c}\phi(\mathrm{mm} / \\
15 \\
\text { menit })\end{array}$ & $\begin{array}{c}\text { Hujan } \\
\text { efektif } \\
(\mathbf{m m})\end{array}$ & $\begin{array}{c}\text { Total } \\
\text { Hujan } \\
\text { Efetif }\end{array}$ \\
\hline 4/26/2017 17:30 & 2,030 & 0 & 2,030 & 0,000 & 52,751 & 47.476 & 3.690 .000 & 3,47 & 10,33 & & 3,47 \\
\hline 4/26/2017 17:45 & 2,032 & 0,6 & 2,032 & 0,000 & & & & & & & \\
\hline 4/26/2017 18:00 & 2,027 & 0 & 2,027 & 0,000 & & & & & & & \\
\hline 4/26/2017 18:15 & 2,035 & 3,6 & 2,035 & 0,000 & & & & & & & \\
\hline
\end{tabular}




\begin{tabular}{|c|c|c|c|c|c|c|c|c|c|c|c|}
\hline $4 / 26 / 2017 \quad 18: 30$ & 2,045 & 1,5 & 2,045 & 0,000 & & & & & & & \\
\hline 4/26/2017 18:45 & 2,070 & 13,8 & 2,057 & 0,014 & & & & & & 3,47 & \\
\hline $4 / 26 / 2017 \quad 19: 00$ & 2,271 & 6,9 & 2,068 & 0,203 & & & & & & & \\
\hline 4/26/2017 19:15 & 2,390 & 1,5 & 2,080 & 0,311 & & & & & & & \\
\hline $4 / 26 / 2017 \quad 19: 30$ & 2,560 & 1,2 & 2,091 & 0,468 & & & & & & & \\
\hline 4/26/2017 19:45 & 2,698 & 0,6 & 2,103 & 0,595 & & & & & & & \\
\hline $4 / 26 / 2017 \quad 20: 00$ & 3,547 & 0,3 & 2,115 & 1,432 & & & & & & & \\
\hline $4 / 26 / 2017 \quad 20: 15$ & 4,970 & 0,3 & 2,126 & 2,844 & & & & & & & \\
\hline $4 / 26 / 2017 \quad 20: 30$ & 5,350 & 0 & 2,138 & 3,212 & & & & & & & \\
\hline $4 / 26 / 2017 \quad 20: 45$ & 5,593 & 0 & 2,150 & 3,443 & & & & & & & \\
\hline $4 / 26 / 2017 \quad 21: 00$ & 5,614 & 0 & 2,161 & 3,453 & & & & & & & \\
\hline $4 / 26 / 2017 \quad 21: 15$ & 5,471 & 0 & 2,173 & 3,298 & & & & & & & \\
\hline $4 / 26 / 2017 \quad 21: 30$ & 5,255 & 0 & 2,184 & 3,071 & & & & & & & \\
\hline $4 / 26 / 2017 \quad 21: 45$ & 4,978 & 0 & 2,196 & 2,781 & & & & & & & \\
\hline $4 / 26 / 2017 \quad 22: 00$ & 4,775 & 0 & 2,208 & 2,567 & & & & & & & \\
\hline $4 / 26 / 2017 \quad 22: 15$ & 4,481 & 0 & 2,219 & 2,262 & & & & & & & \\
\hline $4 / 26 / 2017 \quad 22: 30$ & 4,211 & 0 & 2,231 & 1,980 & & & & & & & \\
\hline $4 / 26 / 2017 \quad 22: 45$ & 3,948 & 0 & 2,243 & 1,705 & & & & & & & \\
\hline $4 / 26 / 2017 \quad 23: 00$ & 3,733 & 0 & 2,254 & 1,479 & & & & & & & \\
\hline $4 / 26 / 2017 \quad 23: 15$ & 3,639 & 0 & 2,266 & 1,373 & & & & & & & \\
\hline Waktu & $\mathrm{Q}(\mathrm{m} 3 / \mathrm{s})$ & $\mathbf{P}(\mathbf{m m})$ & $\begin{array}{c}\text { Baseflow } \\
(\mathrm{m} 3 / \mathrm{s})\end{array}$ & $\begin{array}{c}\text { DRO } \\
(\mathrm{m} 3 / \mathrm{s})\end{array}$ & $\begin{array}{c}\text { Total } \\
\text { DRO } \\
(\mathrm{m} 3 / \mathrm{s})\end{array}$ & $\begin{array}{c}\text { Volume } \\
\text { DRO } \\
\text { (m3) }\end{array}$ & $\begin{array}{c}\text { Luas } \\
\text { DTA }(\mathbf{m} 2)\end{array}$ & $\begin{array}{l}\text { Tebal DRO } \\
\quad(\mathrm{mm})\end{array}$ & $\begin{array}{c}\phi(\mathrm{mm} / \\
15 \\
\text { menit })\end{array}$ & $\begin{array}{c}\text { Hujan } \\
\text { efektif } \\
(\mathbf{m m})\end{array}$ & $\begin{array}{c}\text { Total } \\
\text { Hujan } \\
\text { Efetif }\end{array}$ \\
\hline $4 / 26 / 2017 \quad 23: 30$ & 3,545 & 0 & 2,278 & 1,267 & & & & & & & \\
\hline $4 / 26 / 2017 \quad 23: 45$ & 3,490 & 0 & 2,289 & 1,201 & & & & & & & \\
\hline 4/27/2017 0:00 & 3,406 & 0 & 2,301 & 1,105 & & & & & & & \\
\hline $4 / 27 / 2017 \quad 0: 15$ & 3,338 & 0 & 2,312 & 1,026 & & & & & & & \\
\hline 4/27/2017 0:30 & 3,286 & 0 & 2,324 & 0,962 & & & & & & & \\
\hline $4 / 27 / 2017 \quad 0: 45$ & 3,244 & 0 & 2,336 & 0,908 & & & & & & & \\
\hline
\end{tabular}




\begin{tabular}{|c|c|c|c|c|c|c|c|c|c|c|c|}
\hline 4/27/2017 1:00 & 3,174 & 0 & 2,347 & 0,827 & & & & & & & \\
\hline 4/27/2017 1:15 & 3,166 & 0 & 2,359 & 0,808 & & & & & & & \\
\hline 4/27/2017 $1: 30$ & 3,092 & 0 & 2,371 & 0,721 & & & & & & & \\
\hline 4/27/2017 $1: 45$ & 3,069 & 0 & 2,382 & 0,687 & & & & & & & \\
\hline 4/27/2017 2:00 & 3,032 & 0 & 2,394 & 0,638 & & & & & & & \\
\hline $4 / 27 / 2017 \quad 2: 15$ & 3,007 & 0 & 2,405 & 0,601 & & & & & & & \\
\hline $4 / 27 / 2017 \quad 2: 30$ & 2,979 & 0 & 2,417 & 0,562 & & & & & & & \\
\hline $4 / 27 / 2017 \quad 2: 45$ & 2,964 & 0 & 2,429 & 0,535 & & & & & & & \\
\hline 4/27/2017 3:00 & 2,932 & 0 & 2,440 & 0,491 & & & & & & & \\
\hline 4/27/2017 3:15 & 2,904 & 0 & 2,452 & 0,452 & & & & & & & \\
\hline $4 / 27 / 2017 \quad 3: 30$ & 2,884 & 0 & 2,464 & 0,420 & & & & & & & \\
\hline 4/27/2017 3:45 & 2,861 & 0 & 2,475 & 0,386 & & & & & & & \\
\hline 4/27/2017 4:00 & 2,834 & 0 & 2,487 & 0,347 & & & & & & & \\
\hline 4/27/2017 4:15 & 2,819 & 0 & 2,499 & 0,320 & & & & & & & \\
\hline $4 / 27 / 2017 \quad 4: 30$ & 2,811 & 0 & 2,510 & 0,301 & & & & & & & \\
\hline 4/27/2017 $4: 45$ & 2,799 & 0 & 2,522 & 0,277 & & & & & & & \\
\hline 4/27/2017 5:00 & 2,781 & 0 & 2,533 & 0,248 & & & & & & & \\
\hline 4/27/2017 5:15 & 2,753 & 0 & 2,545 & 0,208 & & & & & & & \\
\hline $4 / 27 / 2017 \quad 5: 30$ & 2,758 & 0 & 2,557 & 0,202 & & & & & & & \\
\hline 4/27/2017 5:45 & 2,733 & 0,3 & 2,568 & 0,165 & & & & & & & \\
\hline Waktu & $\mathrm{Q}(\mathrm{m} 3 / \mathrm{s})$ & $\mathbf{P}(\mathbf{m m})$ & $\begin{array}{c}\text { Baseflow } \\
(\mathrm{m} 3 / \mathrm{s})\end{array}$ & $\begin{array}{c}\text { DRO } \\
(\mathbf{m} 3 / \mathbf{s})\end{array}$ & $\begin{array}{c}\text { Total } \\
\text { DRO } \\
(\mathrm{m} 3 / \mathrm{s})\end{array}$ & $\begin{array}{c}\text { Volume } \\
\text { DRO } \\
\text { (m3) }\end{array}$ & $\begin{array}{c}\text { Luas } \\
\text { DTA }(\mathbf{m} 2)\end{array}$ & $\begin{array}{l}\text { Tebal DRO } \\
\quad(\mathrm{mm})\end{array}$ & $\begin{array}{c}\phi(\mathrm{mm} / \\
15 \\
\text { menit })\end{array}$ & $\begin{array}{c}\text { Hujan } \\
\text { efektif } \\
(\mathrm{mm})\end{array}$ & $\begin{array}{c}\text { Total } \\
\text { Hujan } \\
\text { Efetif }\end{array}$ \\
\hline $4 / 27 / 2017 \quad 6: 00$ & 2,733 & 0 & 2,580 & 0,153 & & & & & & & \\
\hline 4/27/2017 6:15 & 2,731 & 0 & 2,592 & 0,139 & & & & & & & \\
\hline $4 / 27 / 2017 \quad 6: 30$ & 2,703 & 0 & 2,603 & 0,100 & & & & & & & \\
\hline $4 / 27 / 2017 \quad 6: 45$ & 2,698 & 0 & 2,615 & 0,083 & & & & & & & \\
\hline 4/27/2017 7:00 & 2,691 & 0 & 2,626 & 0,064 & & & & & & & \\
\hline 4/27/2017 7:15 & 2,673 & 0 & 2,638 & 0,035 & & & & & & & \\
\hline
\end{tabular}


